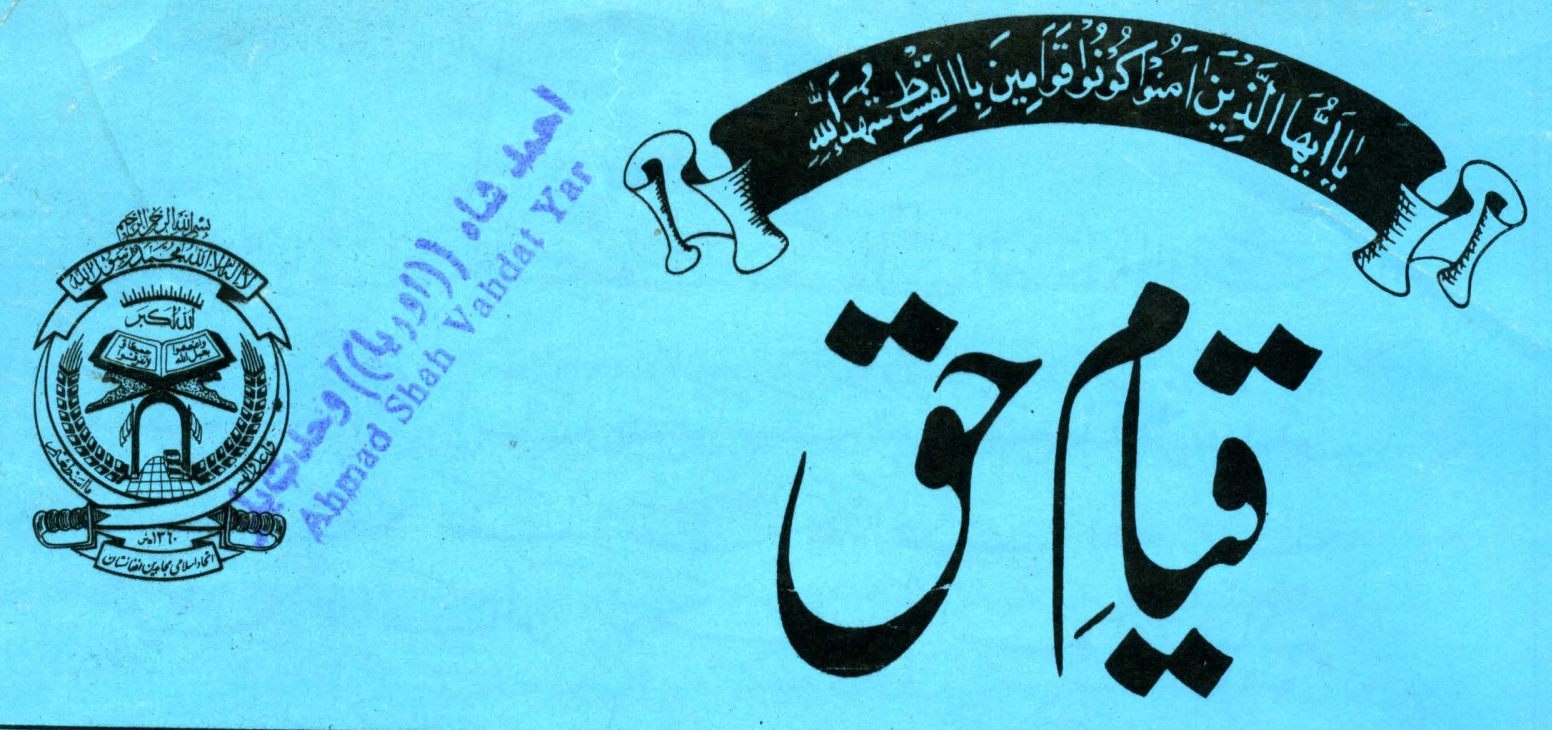

Iralu

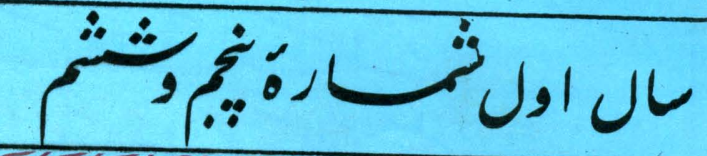

س.

कen

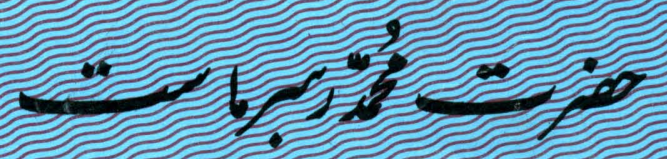

- lubotip

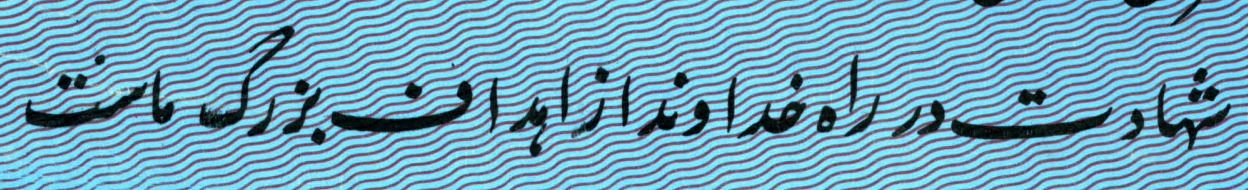

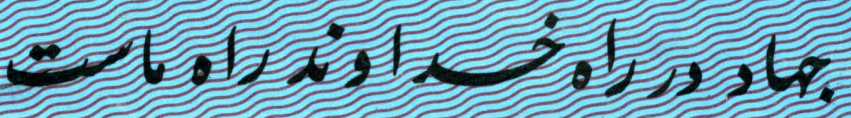
, 1.1.1 , thent 


\section{• •}

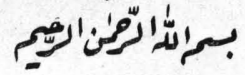

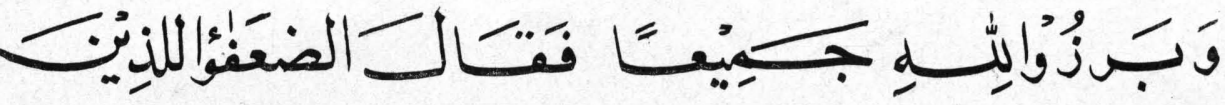

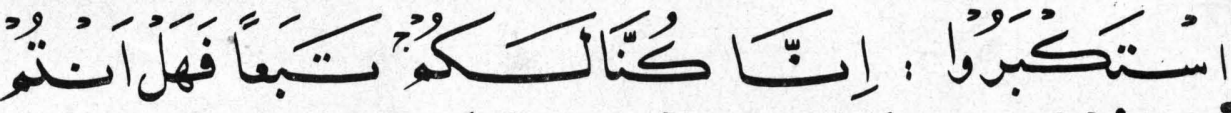

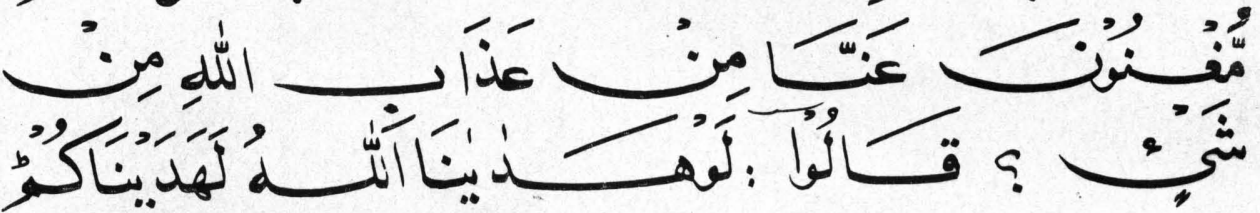

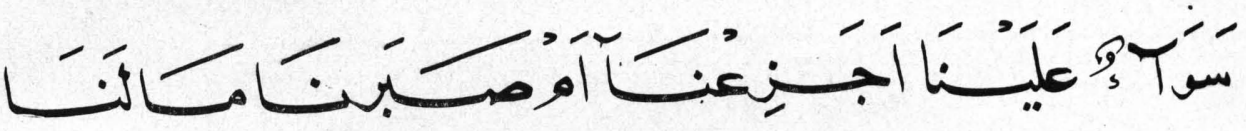

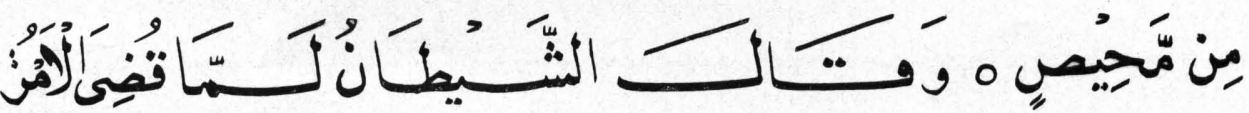

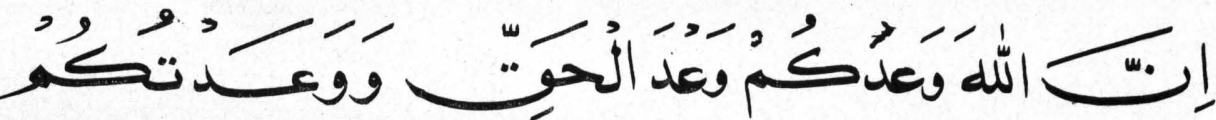

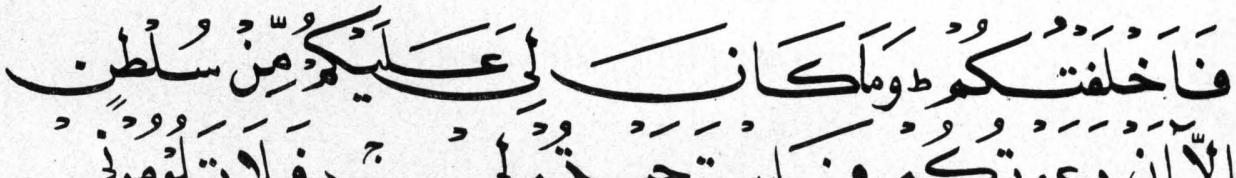

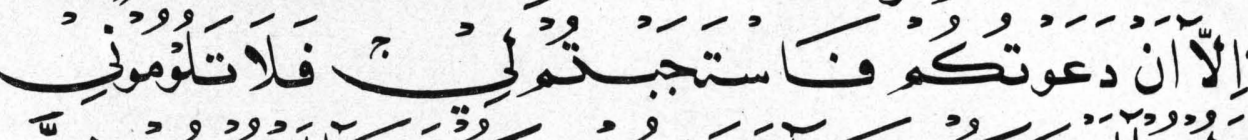

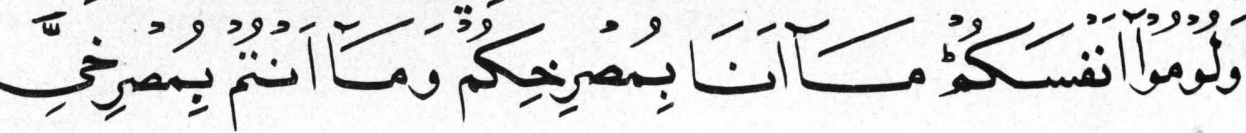

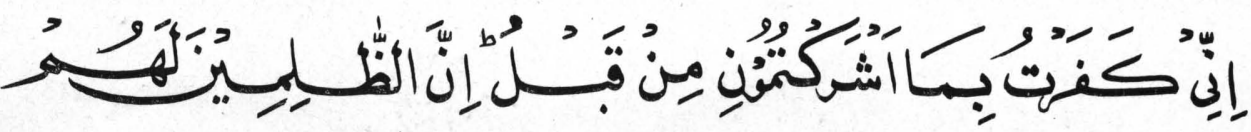

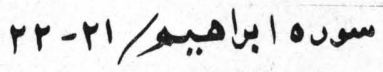

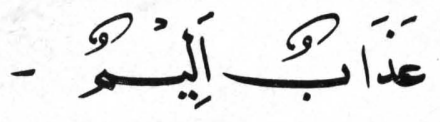

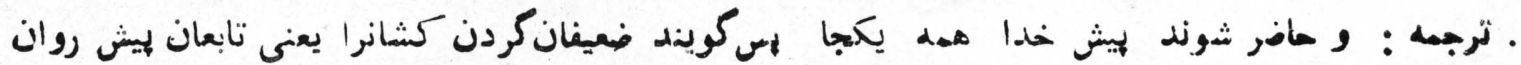

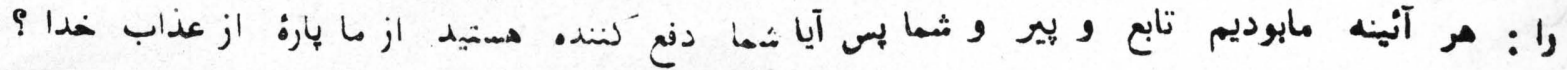

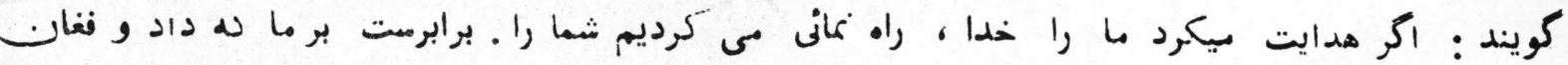

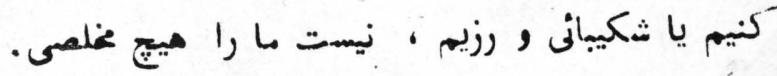

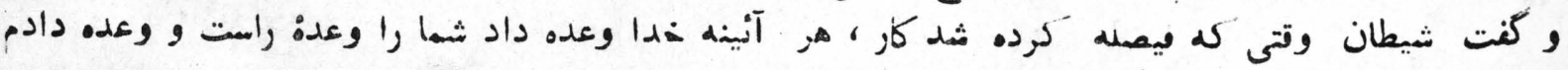

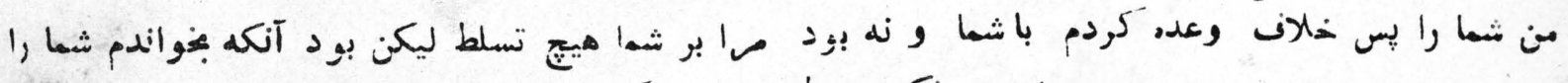

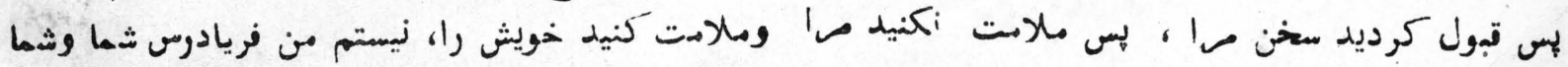

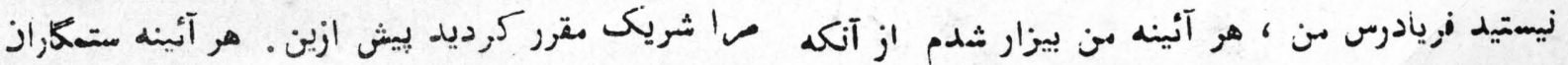
رامت عذاب دردناكى. 




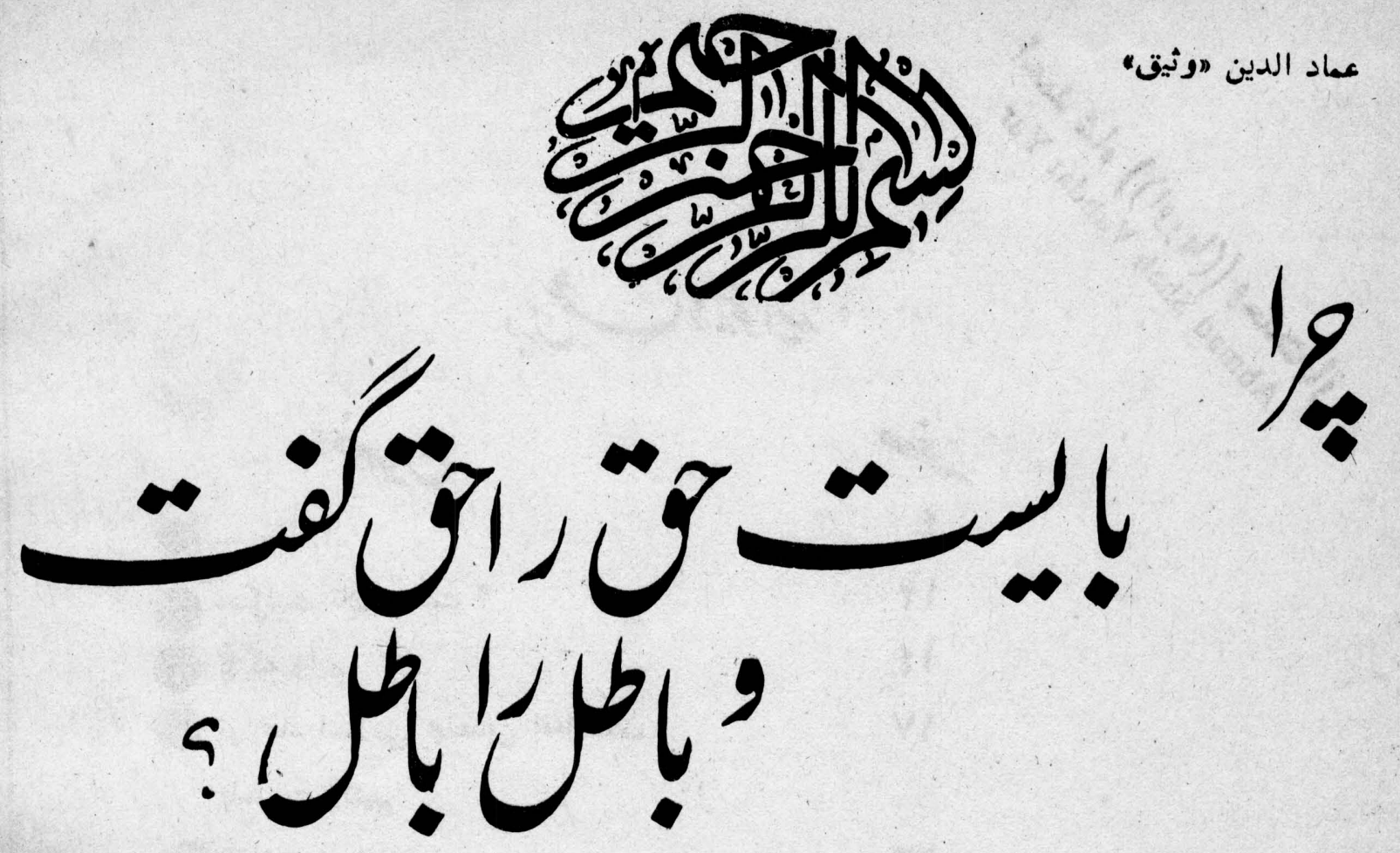

نام اين بجله هقيام حقى امت. حتى كه بس از لهك ليهكار و كشمكث مستمر و متداوم- در برابر باطل به بيروزى رسيده است.

"قهامحت" يعنىمثل داعيل برحتعلماى داعيون

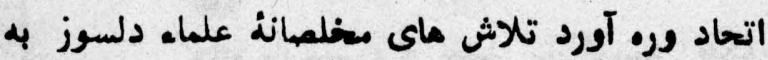

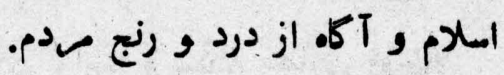

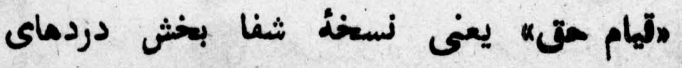

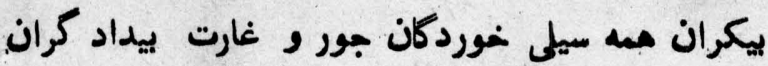
زمان.

شآلهام مثى يعنى مشت كو بنده و شكست

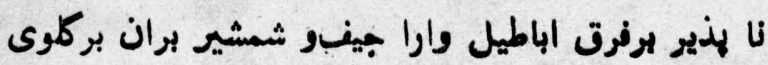
جباران و ستمكاران زمين.

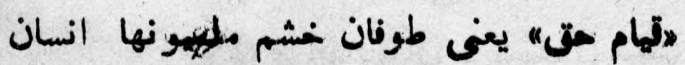

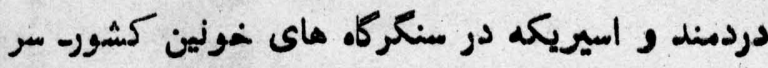

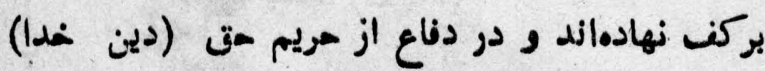

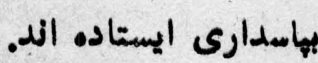

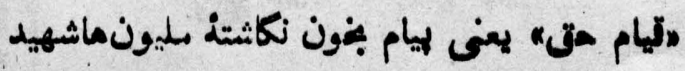
راه خدا كمه مارا به ثبات و بايدارى دعوت ميكند و
خواندكان ارجمند بجلة "قيامحت" مطلع خواهند

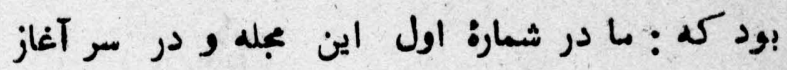

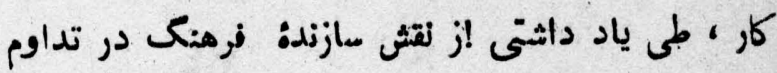

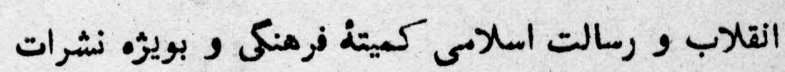

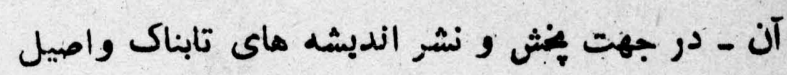

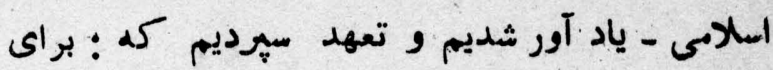

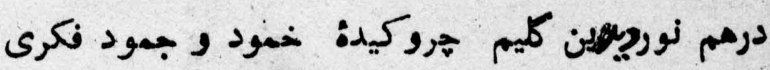

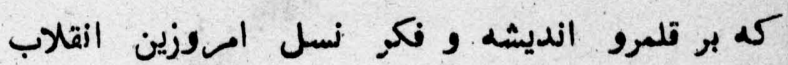

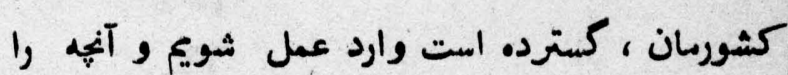

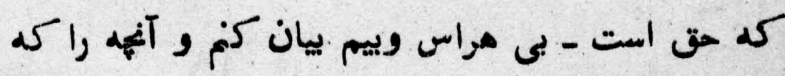

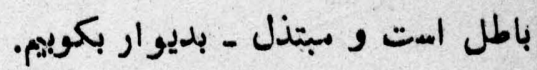

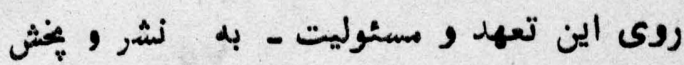

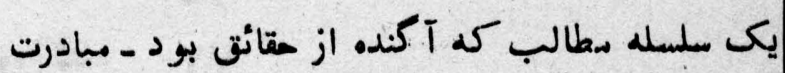

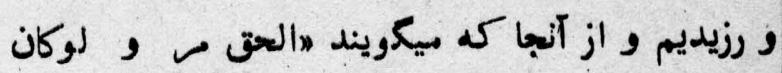

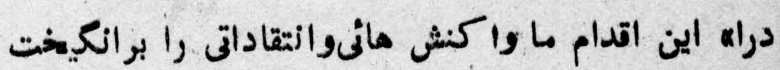

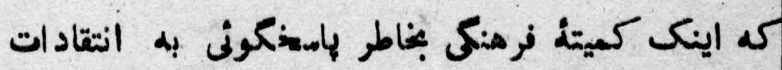

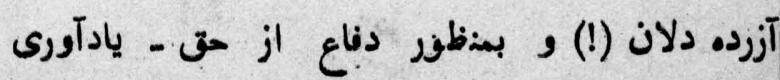
مطالبى هند را لابدى و ضرورى ميدالد : 
آكه ر يا ناخود آكه درسرا شيب سقوط , ملا كت ترار ميكيرند مدف ديكرى نداريم.

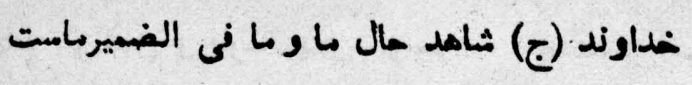

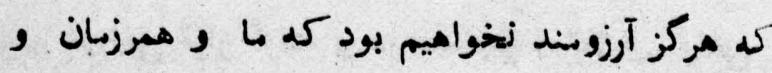

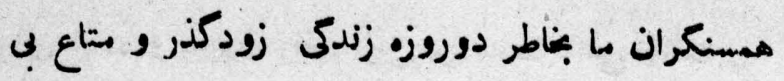

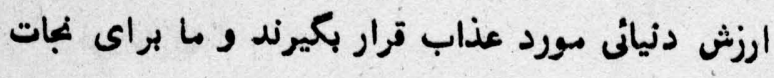
ثان حرن نكونيم. إس خوانند: عزيز برادر و خواهرهد فهند و مبارئ

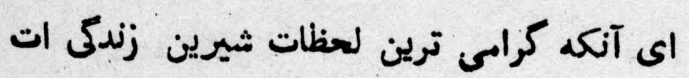

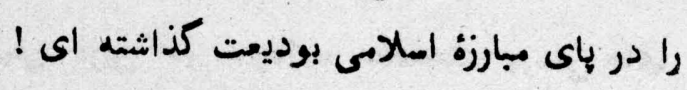

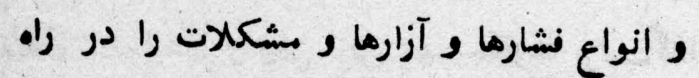

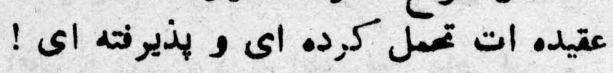

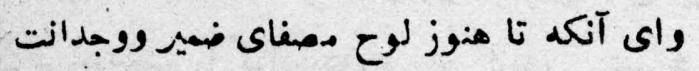

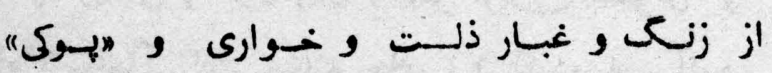

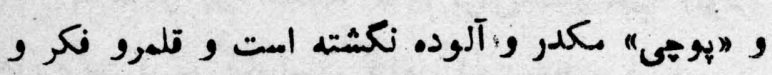

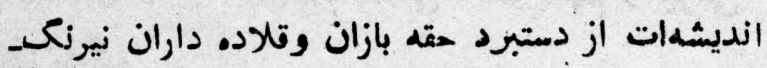

باز زمان عغوظ و در امان مانده امت ـ . . . واى كسيكه عمرى است - براى رهائى اميران

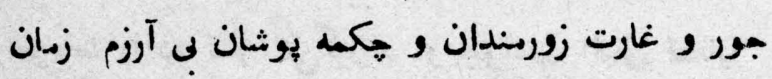

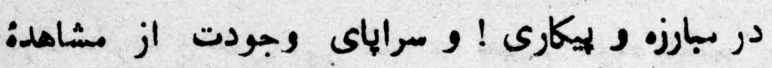

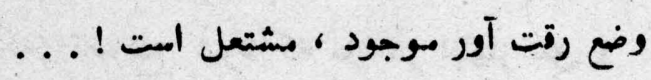

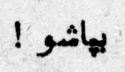

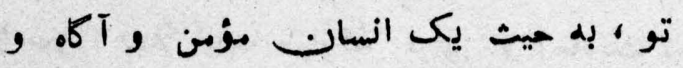

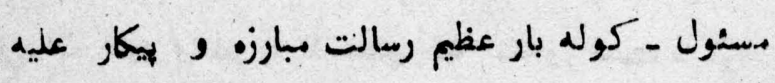

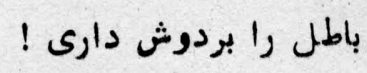
زبا برخيز ! برد إن

ر بذزياد و استغاثئ انسانهاى شلات خوردة اسير و دردمنيل وطنت كوث فراده ! كه : با نالهماى حزين شاذ - من و ترا بيارى و غمكسارى فرا ميخوانند.

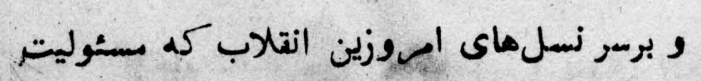

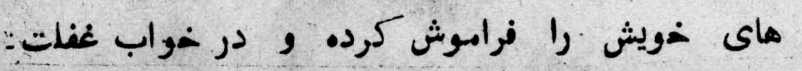

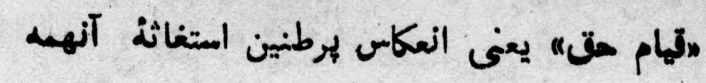

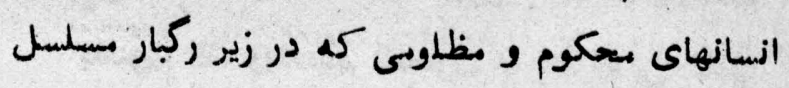

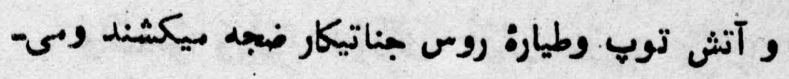
نالند و من و ترا ييارى و غمكسارى ميطلبند.

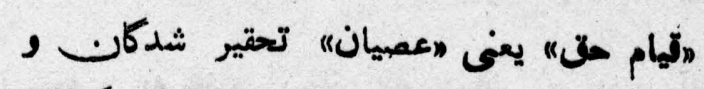

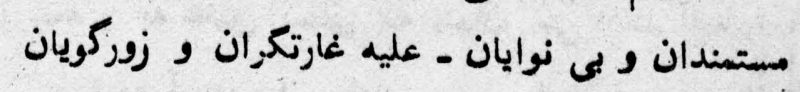

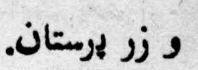

"اليام مق" يعنى اعلان آزادى و, رمائى انسان

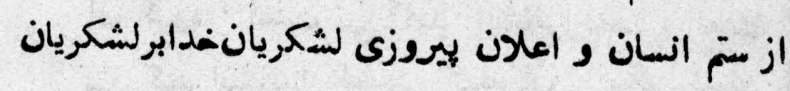

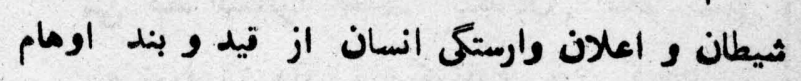

$$
\text { , آلود5يها و.... }
$$

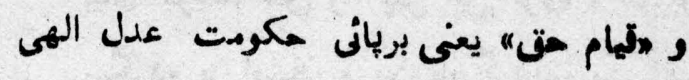

2ر زمين.

ادارة اين بجله و, همكاران قلى آن ـ بنا بر تعهد

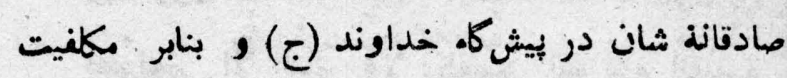

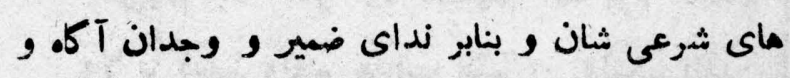

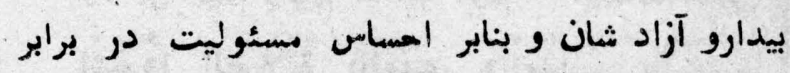

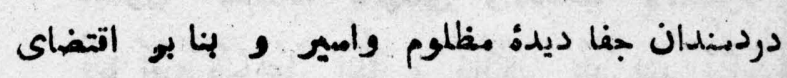

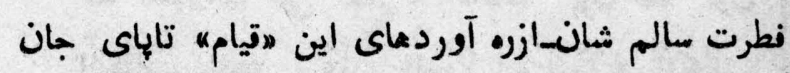

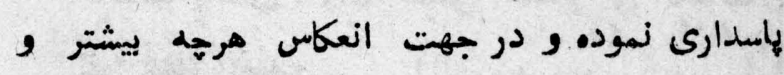

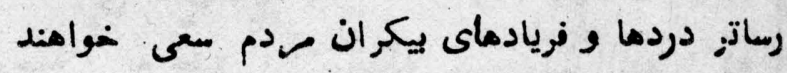

ماهدر بر رسى مساتل و نار مائيهاى موجود ، ورزيد.

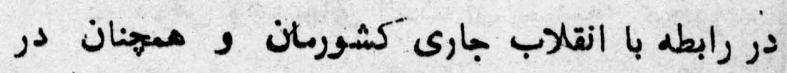

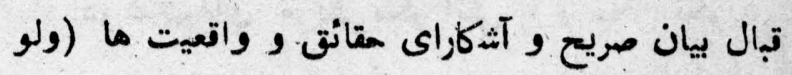

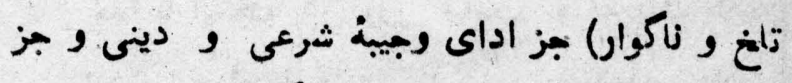

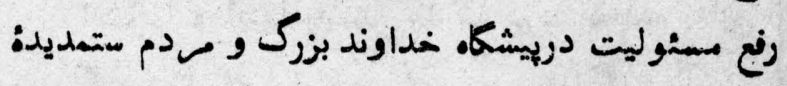

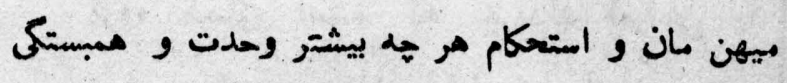

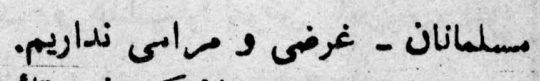

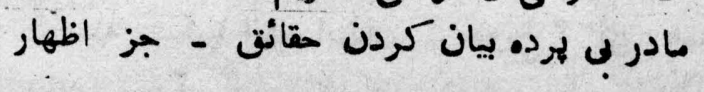

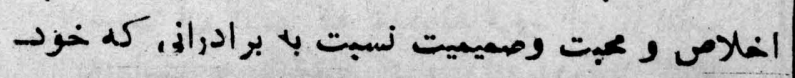




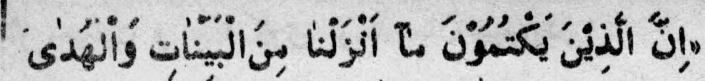

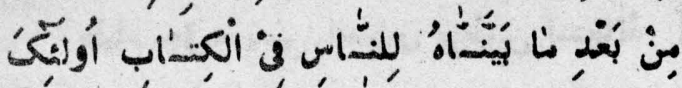

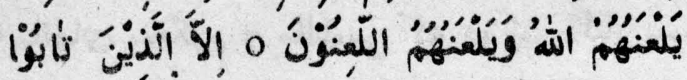

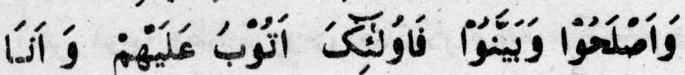

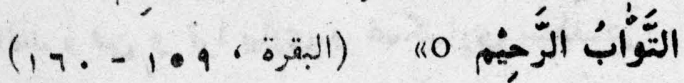

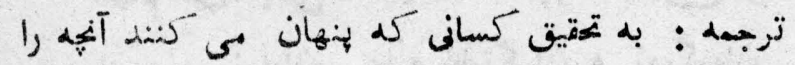
فوود آورديه از معغنان روثن و هدايت بعد از

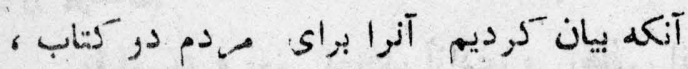

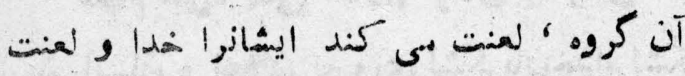

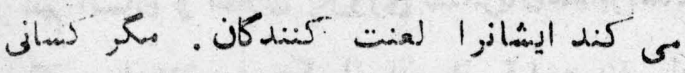

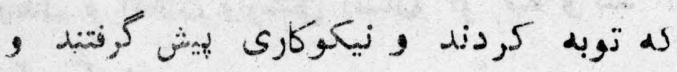

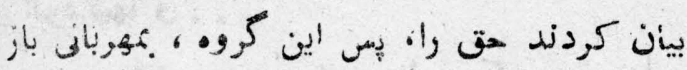

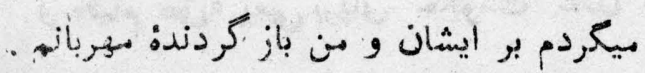

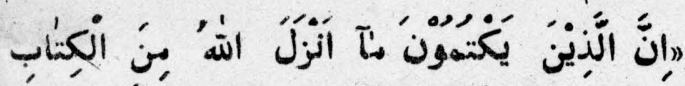

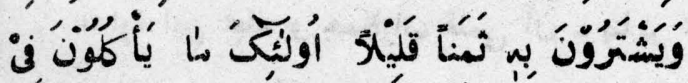

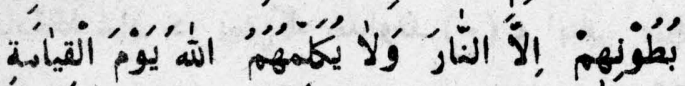

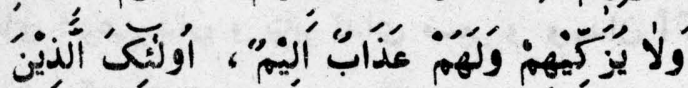

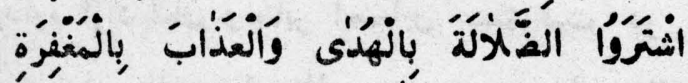

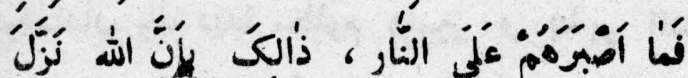

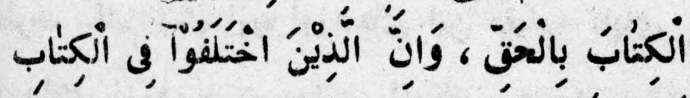
(.

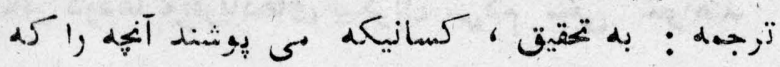
فروة آورده است خدا از كتاب و مي متانيد در عوض وى بهاى ازدك آن بجهاعه' ميخغورند در شكمهاى خويش مكر آتث را و سخن نمويد

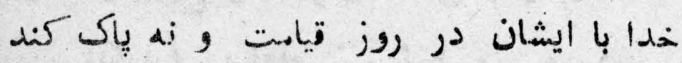

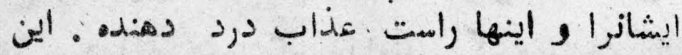

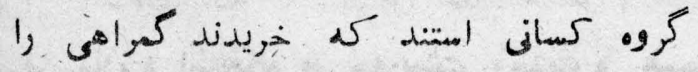
عوض هدايت و عذاب را عوض آمرزث، يس

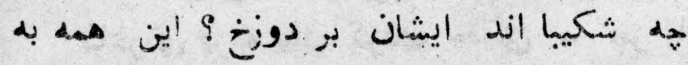

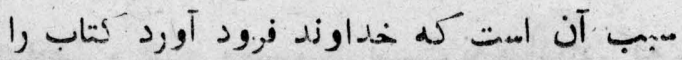

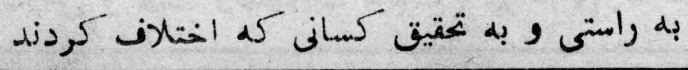

زرورفته انله و يا نا هورد آكاه دز دام فريسب و اغواى

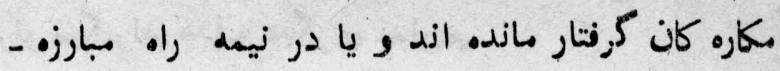
بنابر نو اقص و نارمانيهاى مو جود ، خستمل و افسرده

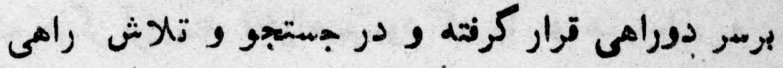
براى نجات و بيرون رفتن ازين بن بست - مى باثمند...

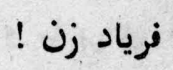

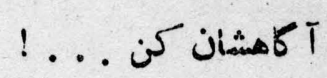

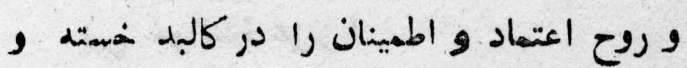

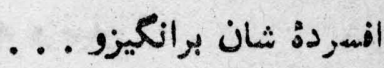

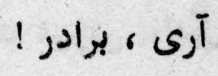

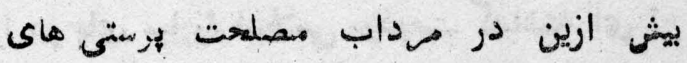
مبتنل - لونيدن و بيث ازين مهر مكوت برلبكذاثتن

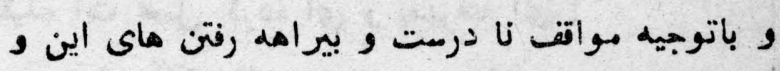

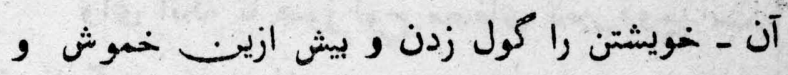

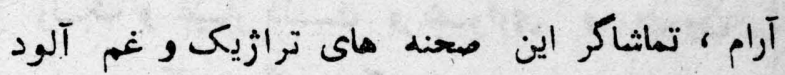

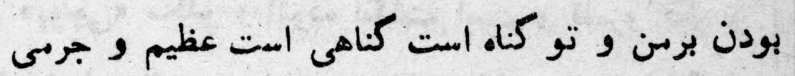
الهت بزرك و اينك براى و ضوح بيشتر بطلبى كله عنوان كريه. ايم و هم براى اينكه به آنعده از برادرانى كه واقعيت

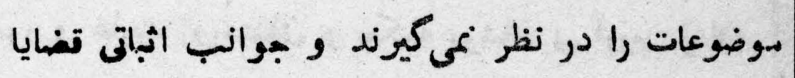

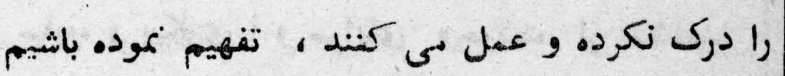

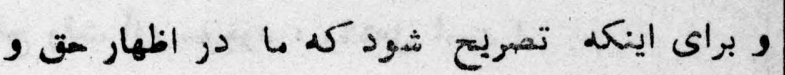
بيان واتعيت ها فتط و فقط مسكفيت املامس داريم

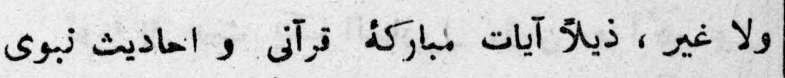

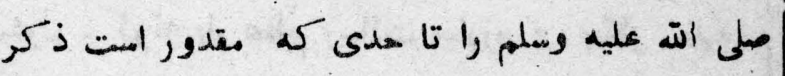
: مينمائيه

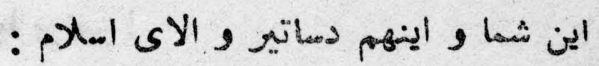

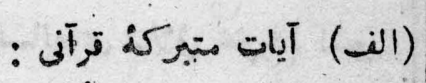

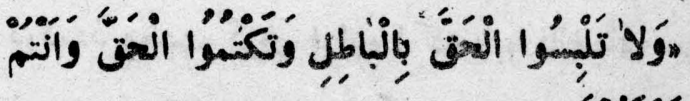

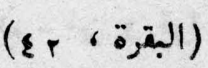

" "نosalá

ترجهمه : و ميوشانيد هق را بباطل : ونهان نكنيد مق را در حاليكه بحقازيت آن آكاهيد. 
كيند و بخوانند بسوى خير و زيكى : امر كينا

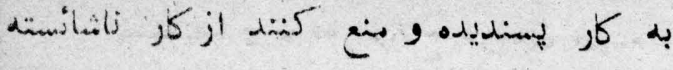

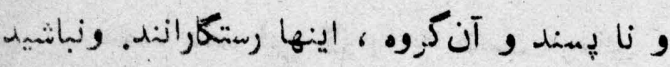

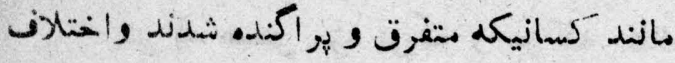
كر دند با همديكر بعد از اينكه آمد به ايشان

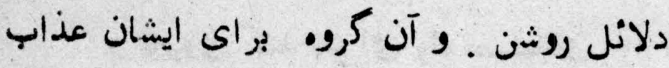
بزرك امست

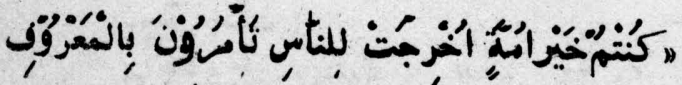

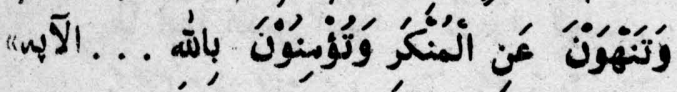
(1.1) (آل عمران)

ترجمه : هستيد شسل بهترين اهتى كل بيرون آورده ثدل براى مسدمان ، امس بى كنيد به كاز هاى يسنديده. و نيخ و منع ميكنيد از كر هاى نا يسنديده و بد و باور ميداريد خدارا. . . .

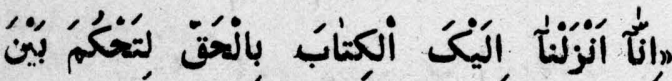

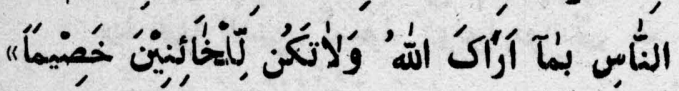
(1.0/alaidi)

ترجمه : هر آئينه ما نرود آورديم بسوى تو كتاب را براستى تا هكم كنى در بين مردم بآنجه شناسا

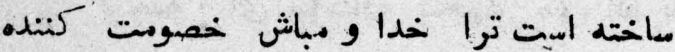
براى حمايت خيانت كنيدكان (مباش لِشتيبالن) - خيانتكاران)

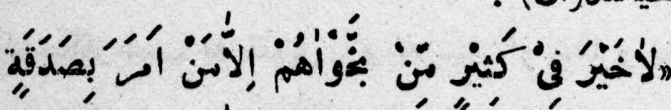

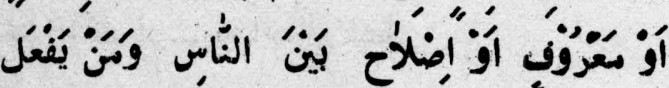

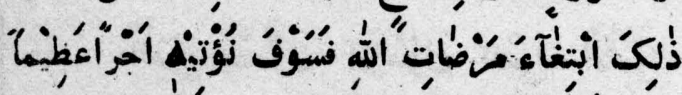

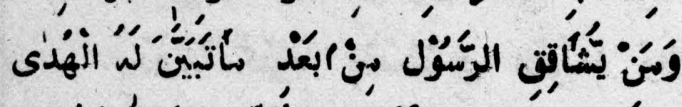

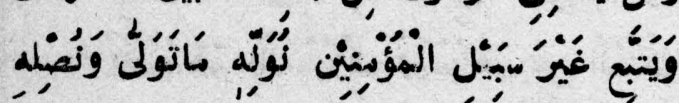
"جنئ

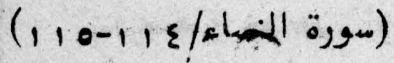

ترجمه : نيمت خيو و نيكى در بسيارى از مشورتهاى

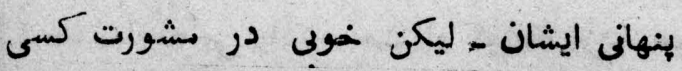

در كتناب هتماً در مخالفت دورند از صواب.

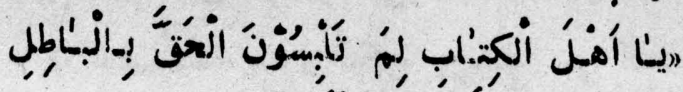

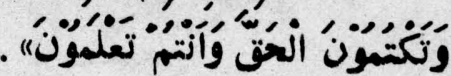

(vi ( آل عمران)

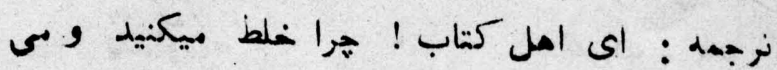

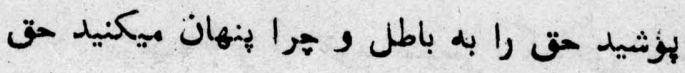

\{diاim

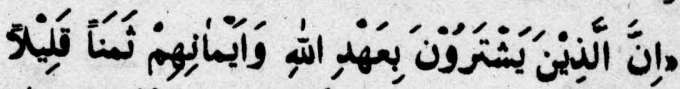

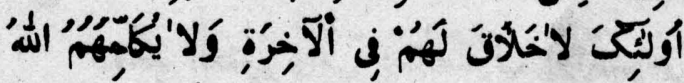

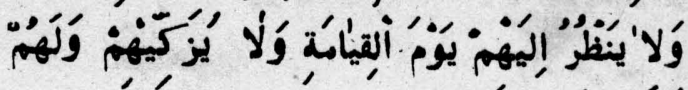

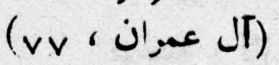

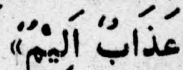

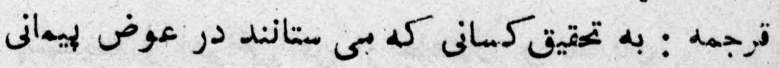

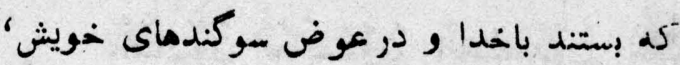
بهاى اندك_آن كرو،؛ هيتج نصيبى نيست ايشانرا

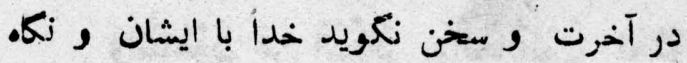
نكند بسوى اينها در روز روز قيامت و براك نسازد ايشاذرا و بر'ي اينهاست عذاب دردناك . .

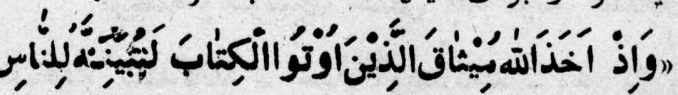

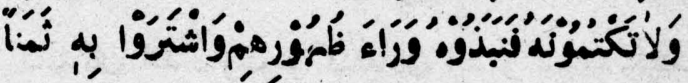

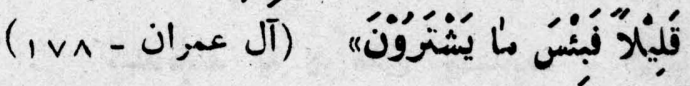

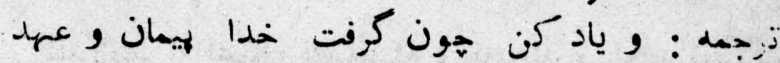

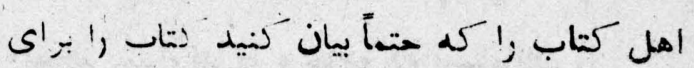

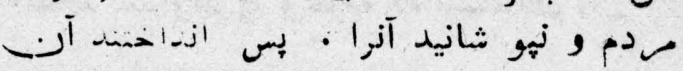

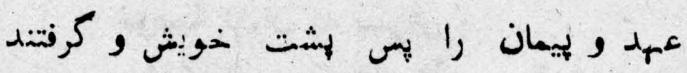

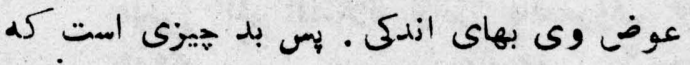
مى سمتانند

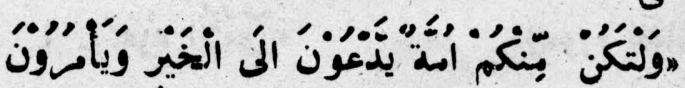

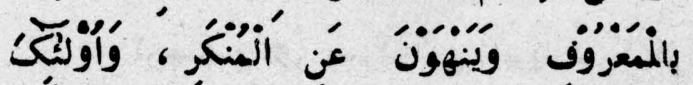

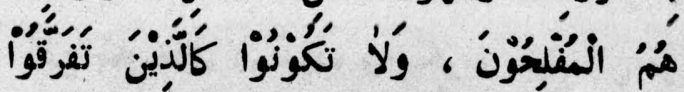

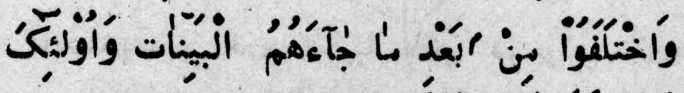

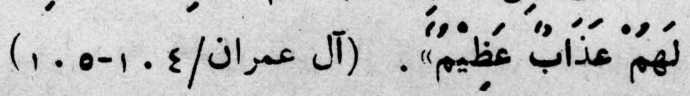
ترجهه : و بايد كله باشد از شها كروهى كه كه دعوت 


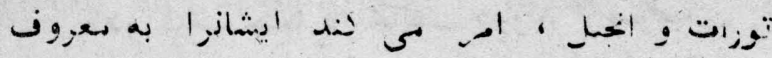

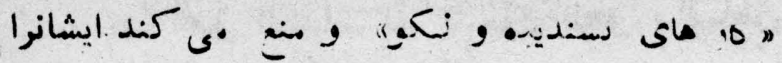

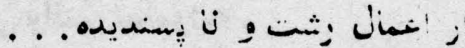

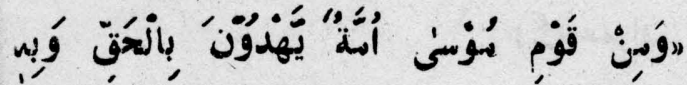

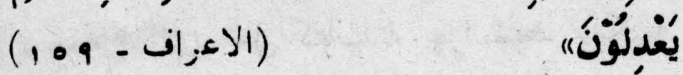
ترجمه : و از قوم موسى كروهى هست كم

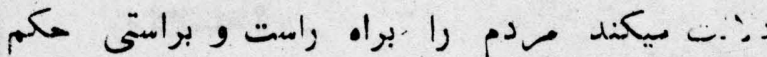

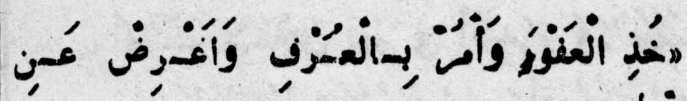

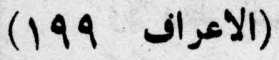
الجَاهلينه" ترجهه : لازم كير عفو را و امـ كن به كارهاى

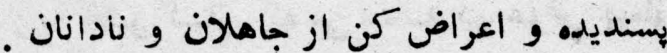

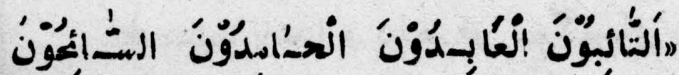

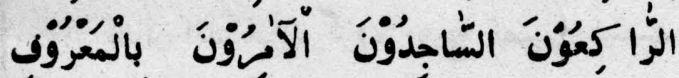

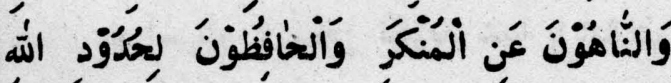

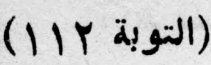

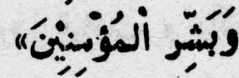
ترجمه : مؤمنين كسانى اند توبه كنندكان اند كاند

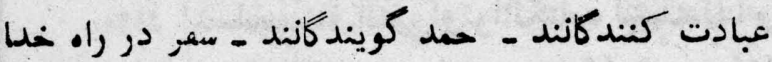

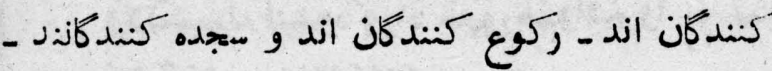

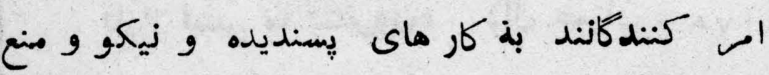

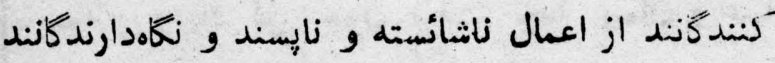

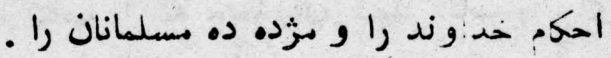
توصيذ لقمان به بِسرش :

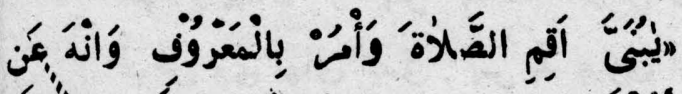

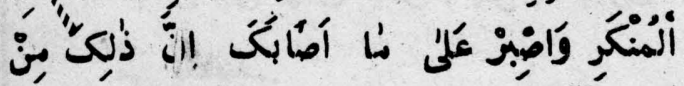
(IV سورة لقمان (1V)

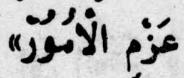
ترجمه : اى ديسرك من ! بريا دار نماز راو امـ

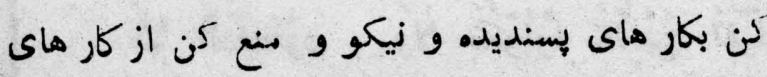

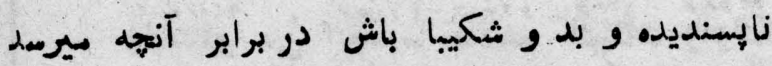

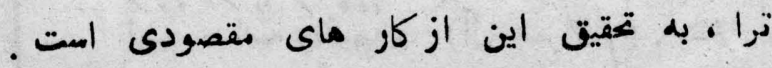
ام بالمعروف و نهى از منكر مفت مسملمان بوده و

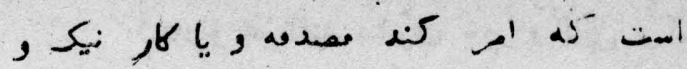

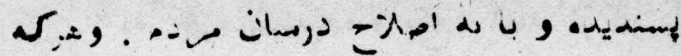

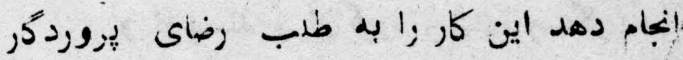

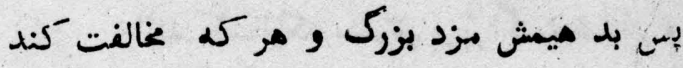

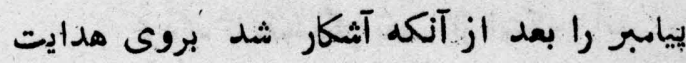

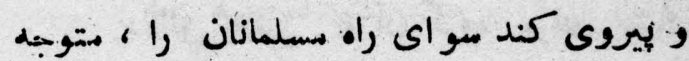

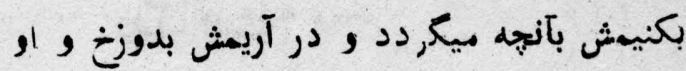

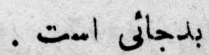

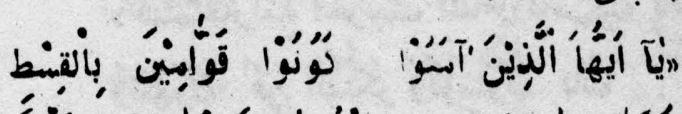

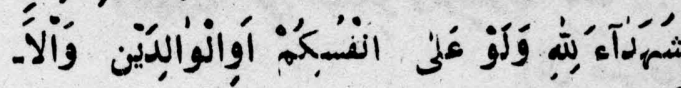

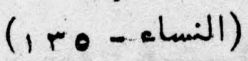

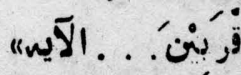

ترجمه : ائ مؤهنان متعهد انصاف باثيد و

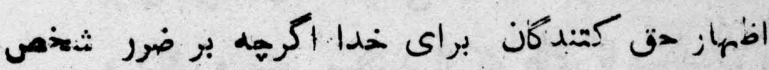

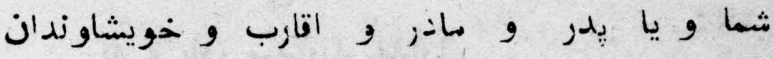

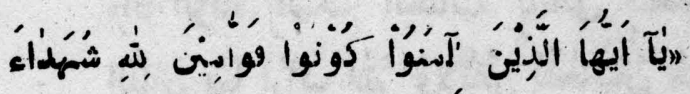

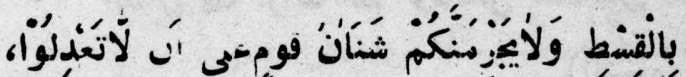

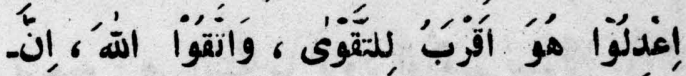

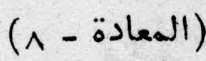

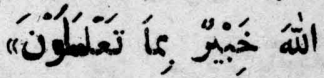
ترجهل : اى مؤمنان هتعهد حتى الته باثيد و

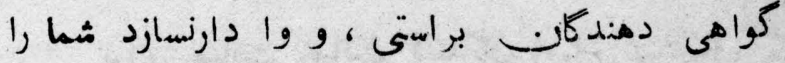

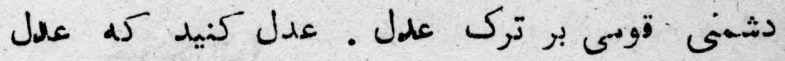
نزديكتر است به تقوى. و بترسيد از خدا و بر به تمقيق

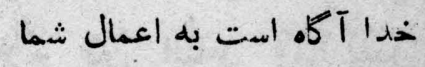

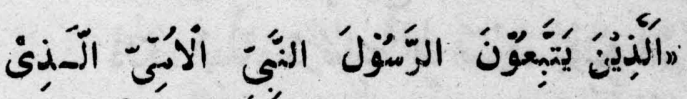

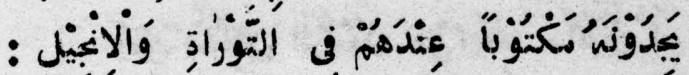

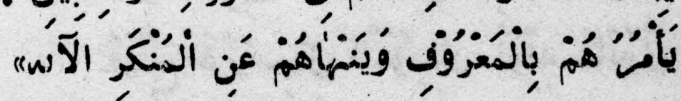
(الآيه الاعررف - (lov)

ترجمه : خوانمم زوثت رحمت اخرويه براى

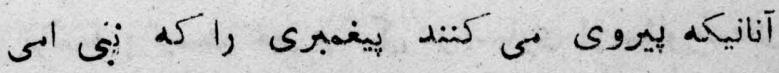

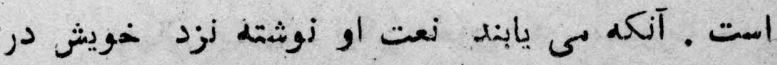




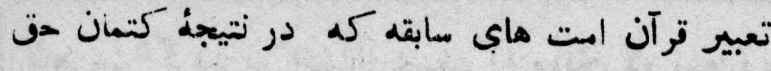

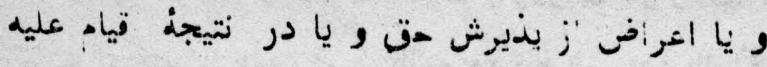

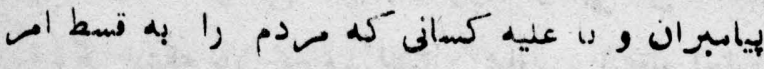

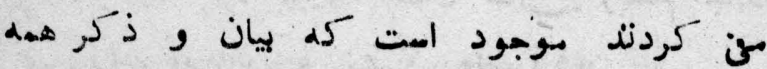

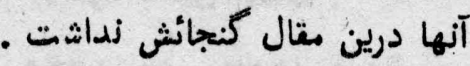
بـ و اين هم احاديث بياسبر بزركوار اهلام سيدنا محمد صلى اله عليه وسلم : مانم

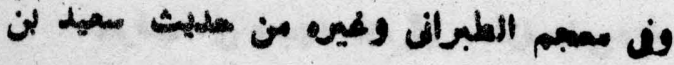

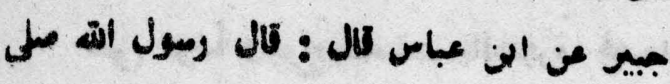

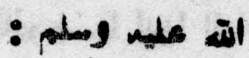

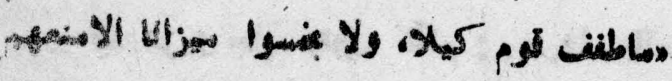

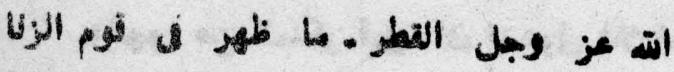

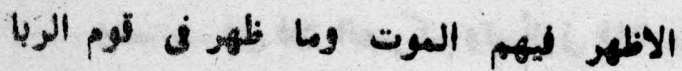

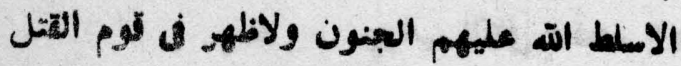

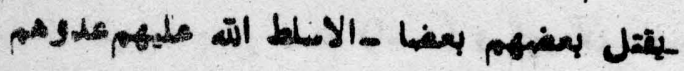

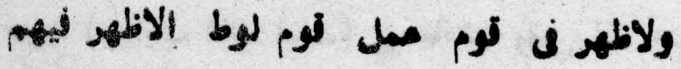

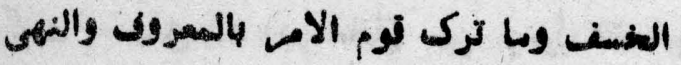

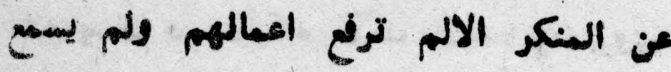

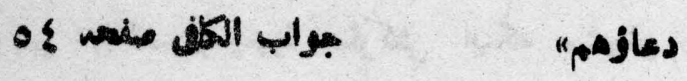

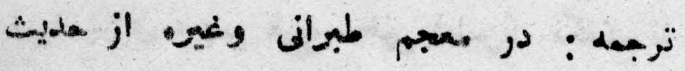

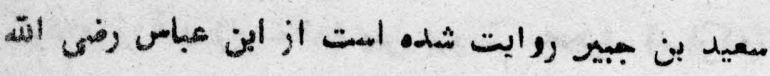
عنه ، وى كنت : فرمود آلهضهرت ملى اله عليه وبملهم:

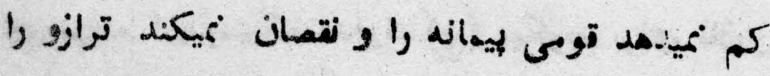

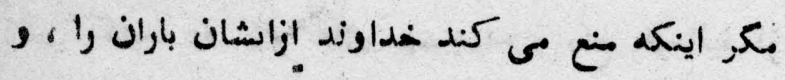
آشكارانميكردد درميان مددمى زنا، مكر اينكه مخداوند

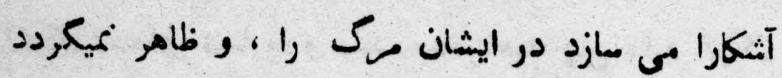

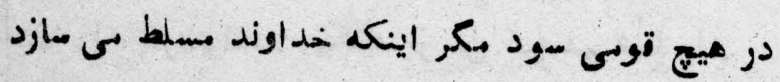

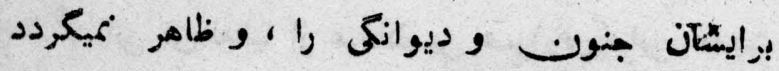

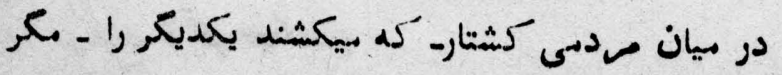

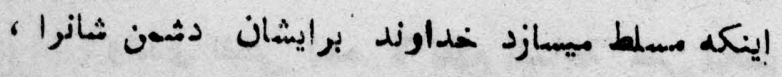

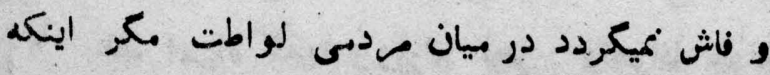

هوعكس صفت منافق آن است كله به منكر امر مىكند

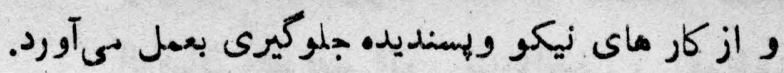
خداوند اين مر دو سورد را هنين بيان ميدارد.

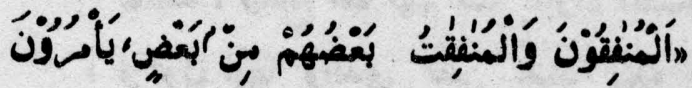

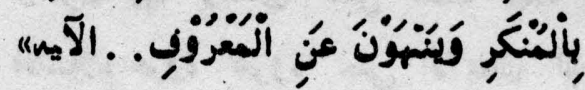
IV التوبة

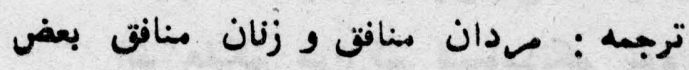

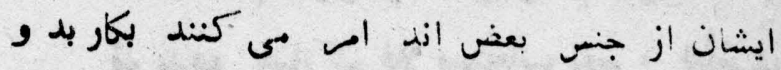

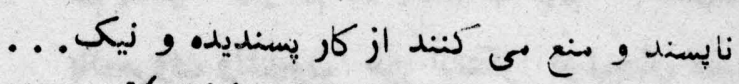

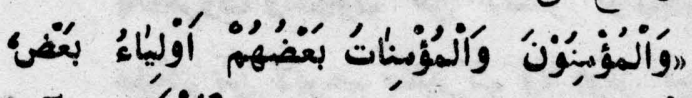

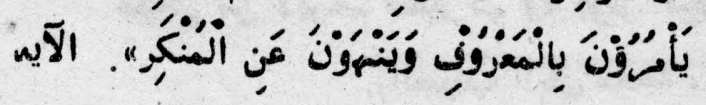

ترجمه : مسدان سملمان و زنان مسلمان بعض ايشانبا بعض ديكر دوست و كار ساز اند.امس ميكنيند

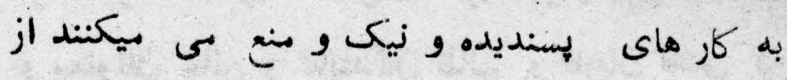
كر هاى نايسندوبد مائ.

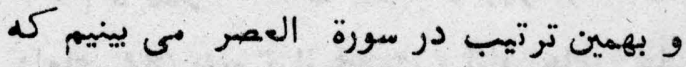

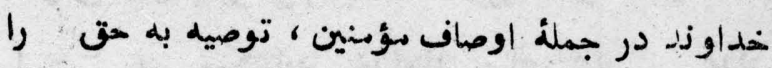
سبب نجات از خسران و زيا:مخارى دانسته وآذ(توصيه) را. يكى از اوصاف بسلمان بيشمارد :

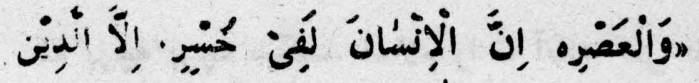

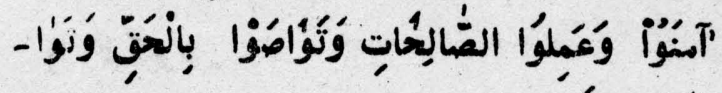

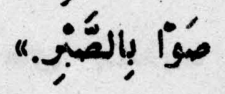
ترجهه : و قسم بزمان ، كمه مر آنينه آدمى در

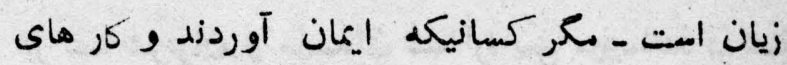

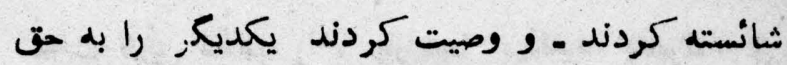

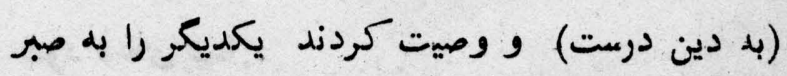

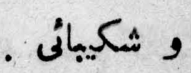

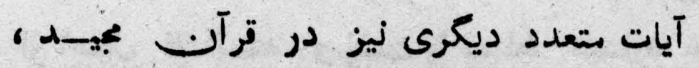

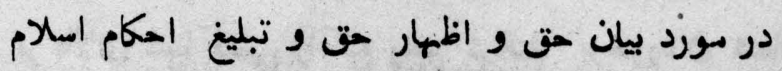

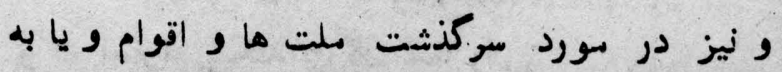


وعرناء ظلمة وتراء ذسقة ، سيهاهم سيهاء الرمبان وتلوبهم اتتن من الجيف ، اموازمه عنلفة ، فينتع الت لهم لكنة فبراء مطلدة فيتها-

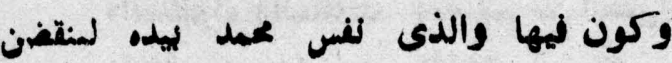

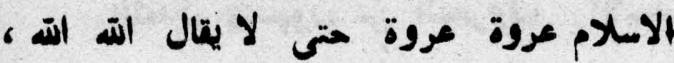

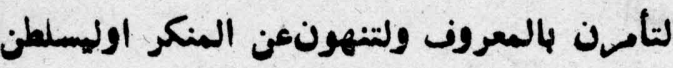

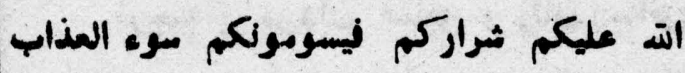

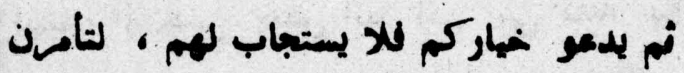

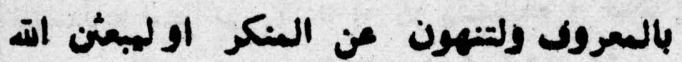
مليكم من لايومم صنيركم ولا يورك كيركم.

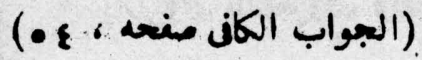

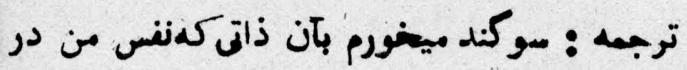

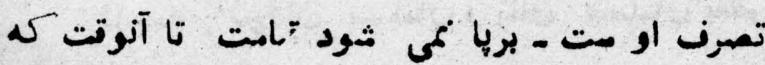

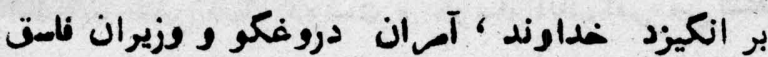
و معاونان خائن و نمايثدكان ظالم و قاريان فاست كن علاز و, بهره ما ثمان علامه و خهر: زامدان الست

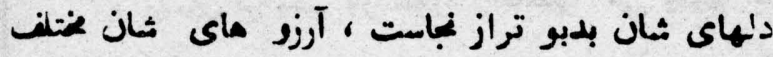
أست . هم ميكشايد خداوند براى شالن عذاب لهاب

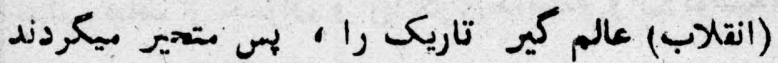

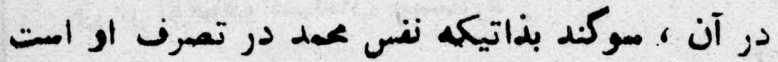

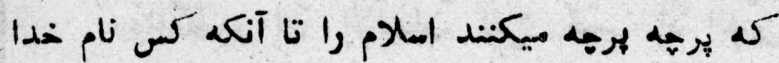

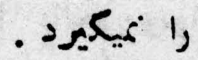

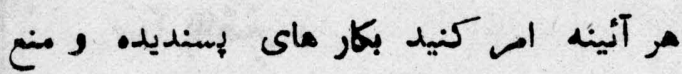
كنيد از اعلال نالهـند يا اينكد خداوند مسلط ميكند بر شها شريران و مغسدان ثمال را بس ميرساند بر شها

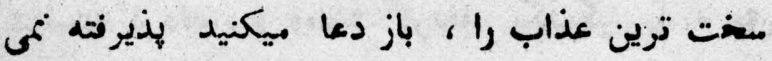
شود دعاى شما. مر آنينه امس كنيد بكار ماى شائسته و منع كنيد از اعمال ناثهائسته و زثت يا مسهلط ميسازد خداوند

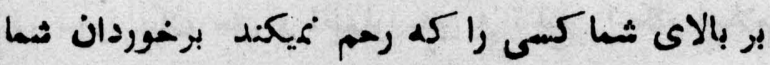

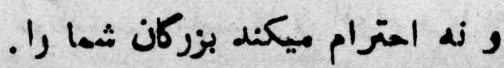

ظلاهر مى كادد در ايشان خديف (فرورتن در زمين) و

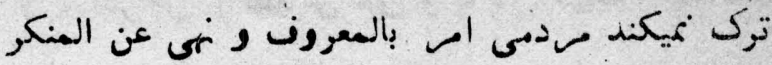

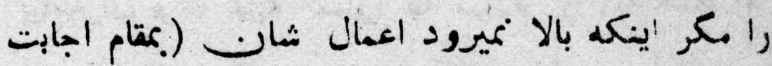
نميرسه) و زه بذيرفته ميشود دعاى ايشان .

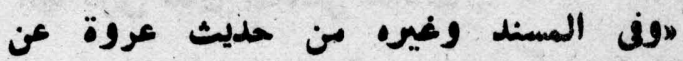

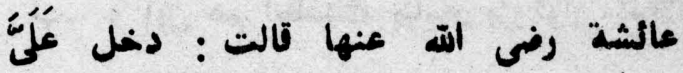
رسول الته ملى الهه عليه وسلم وقد هفزه النغس.

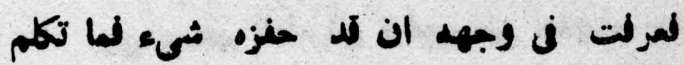

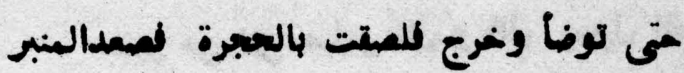

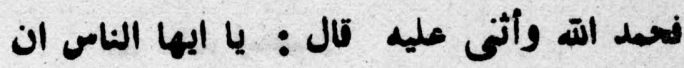
الته مز و جل بتول لكم : مروا بالسعروف عله وانهوا عن الهنكر تبل ان تدعونى فلا ابهيكم

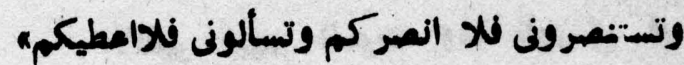

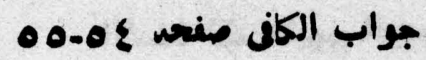

ترجمه : در مسمند (احمد) و غير آن از ملهديث

عروه (روايت شده است) از عائشه رضى الت عنه كم

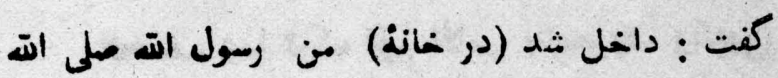

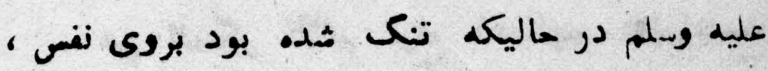

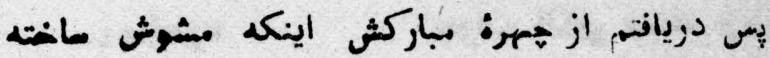

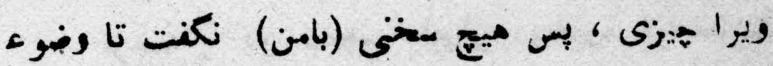

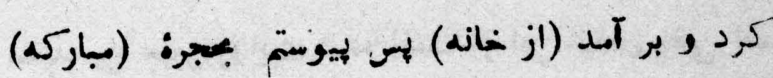

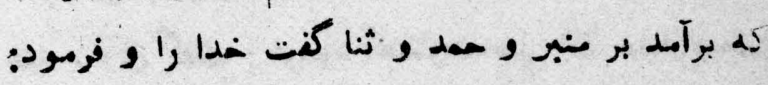

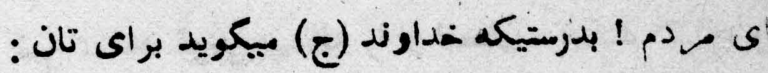

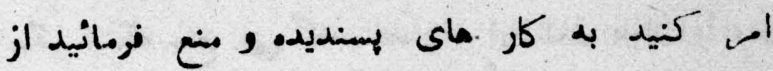
كاز هاى نإيسند بيش از آنكه دغا ميكنيد مرا ، اجابت

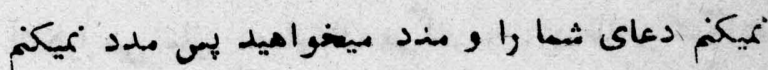

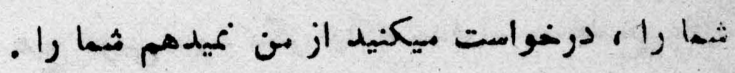

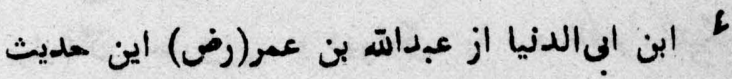

$$
\text { ا مرفوع ذكر ميكند : }
$$

والذى نلسى اليده لا تتوم الساعة متى يبعث

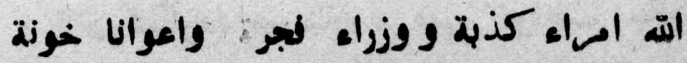




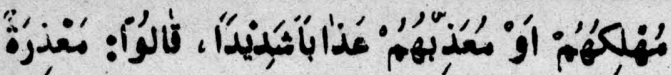

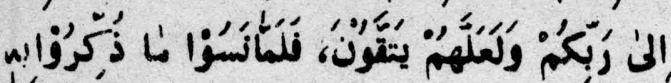

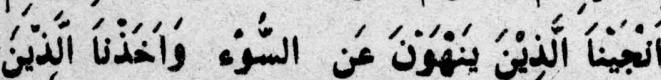

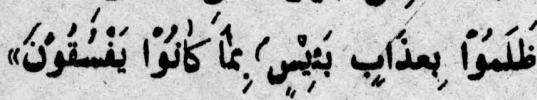

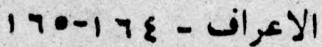

ترجمه : و يا دكن هون كفت كرومى از اهل آن د. (آن ديهى كم مركشى و نافرمانى كردند)

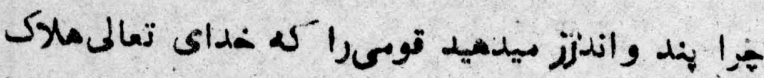

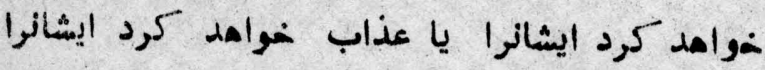

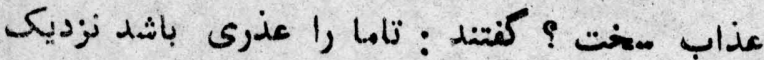

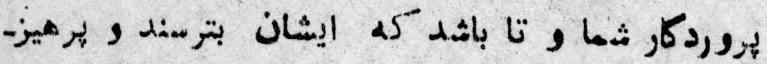

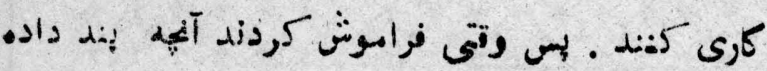
ثيد ايشانرا ، نجات داديم كسانن راك كه منه ميكردند

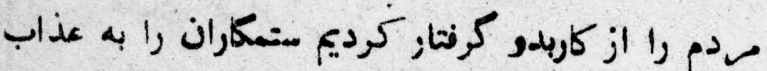

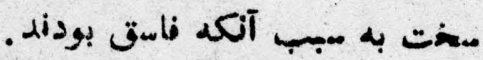

$$
\text { آرى • تومم اى خوانند: عزيز ! }
$$

با در نظر داثت فرامين الههى , ارثادات

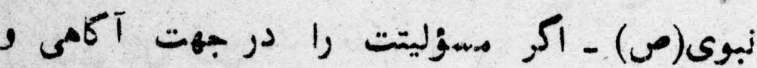

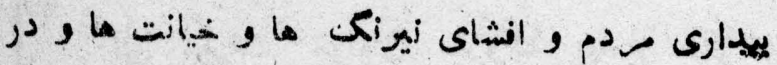

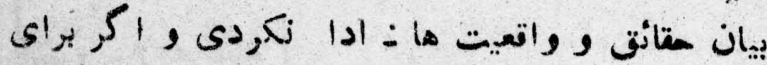

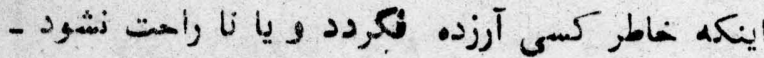

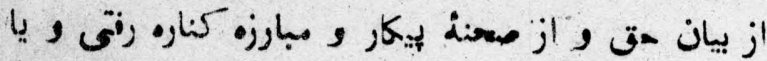

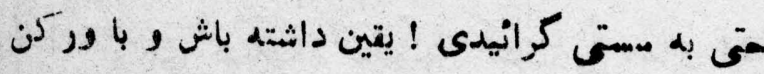

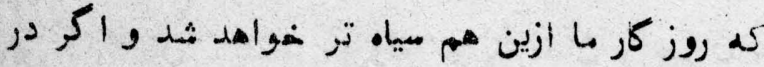

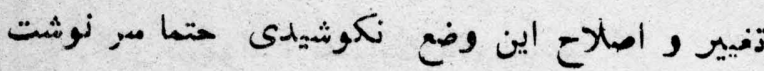

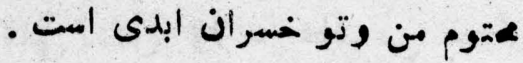

خداوند مهن ما را بلطف و عنايت بيدريغش

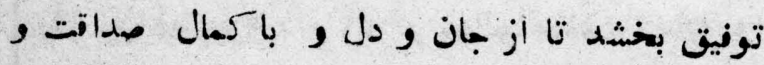

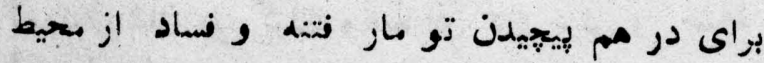

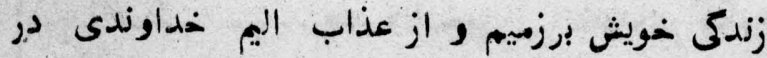

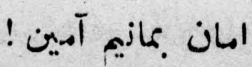

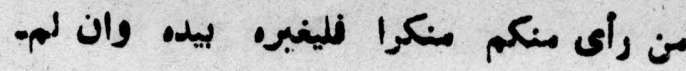

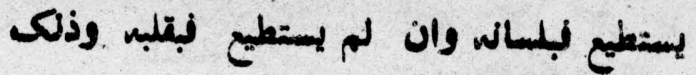
اخفي الائطان....

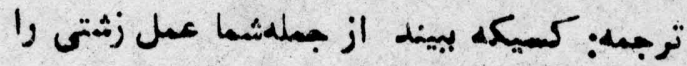

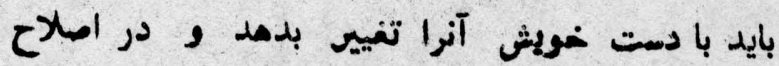

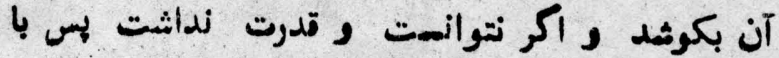

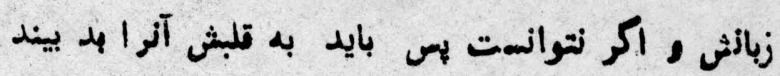

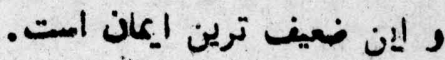

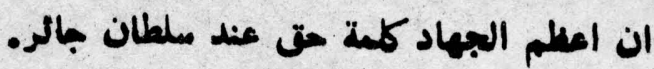

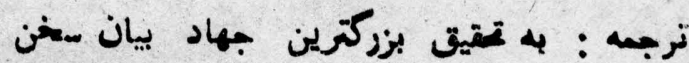

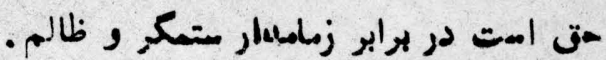
بنا بر دماتير و اسكلم فوق الذكر دين مقدس

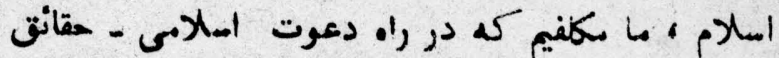

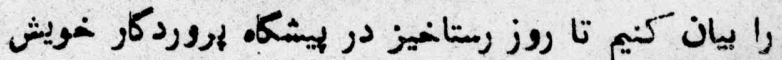

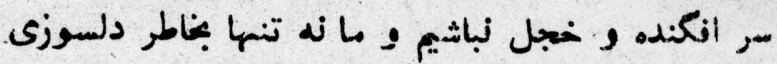

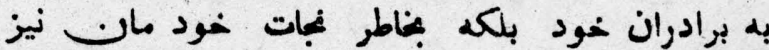

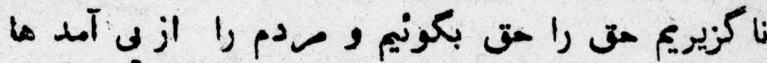

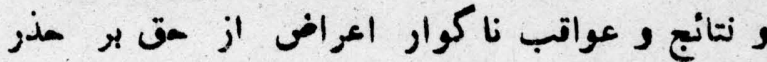
داريم

در روزكران عضرت موسى عليه السلام - زمانن

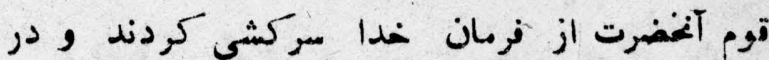

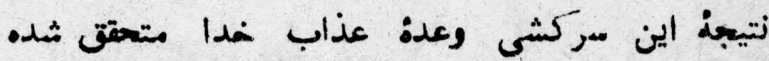

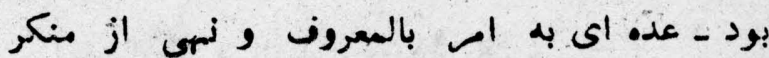

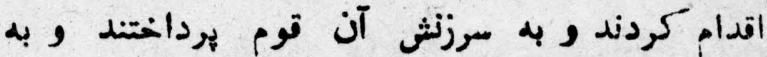

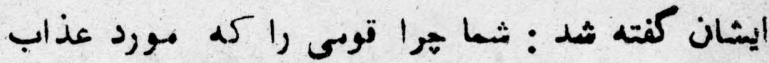

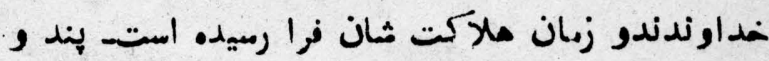

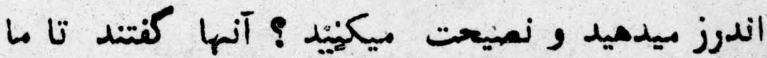
لزد لروردكار خويش عذرى و بهانه اى بـ اي نجات

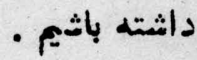

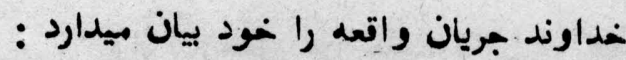

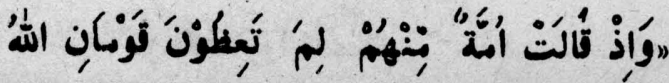




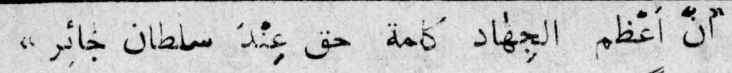

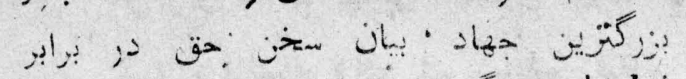

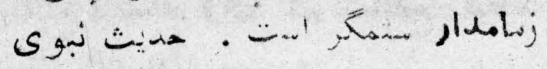

قاش

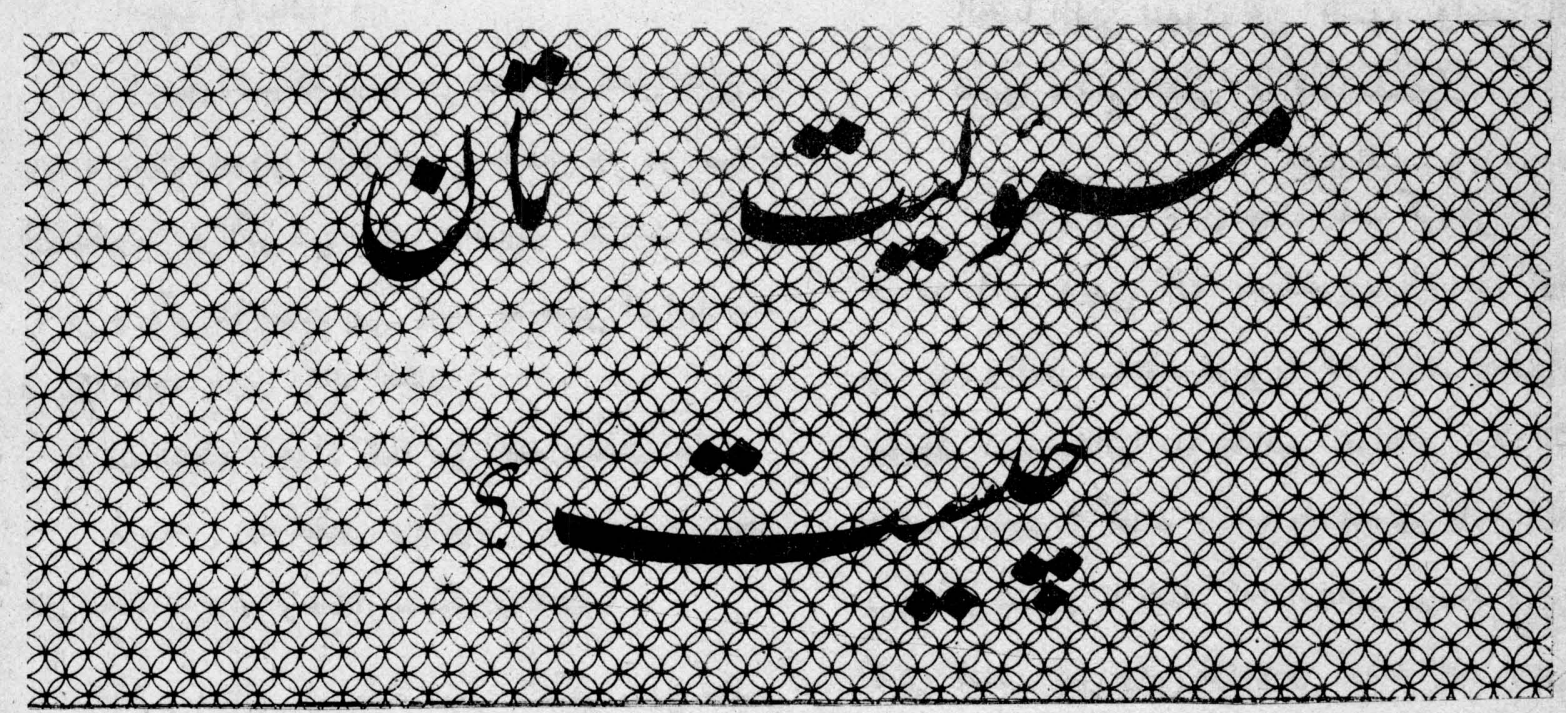

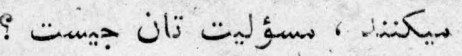

آ

بيايد ، قازون و ضابعله

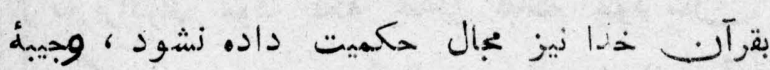

ت

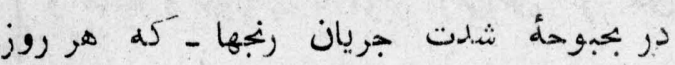

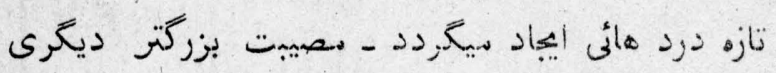

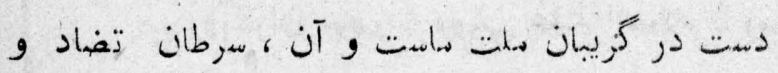

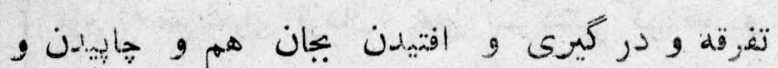

قايِيدن هُوق حقُ همديكر است ، در قبال اين وضع

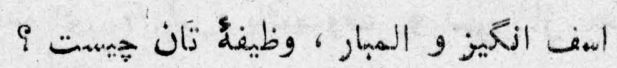

ياد دهانى اين زكته از يبام سركشاده وسول خدا

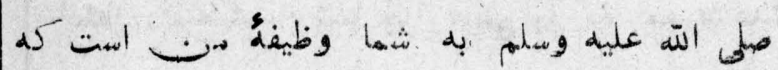

|بفرمايد :

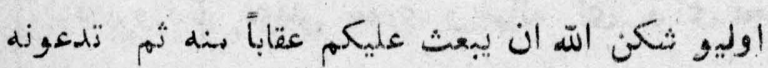

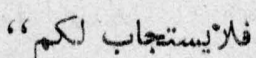

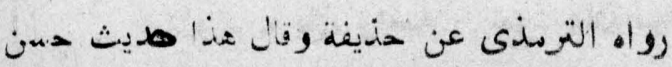

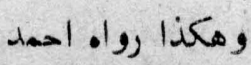

علماى كر ام !

إنشماندان

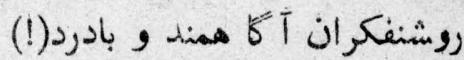

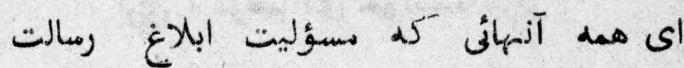

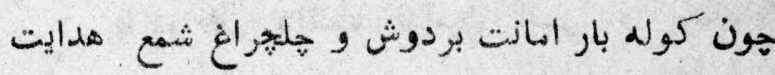

بردست تان است !

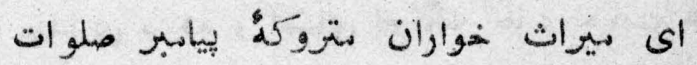

الشه و سلالهن عليه

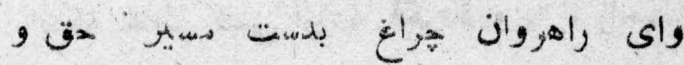

!

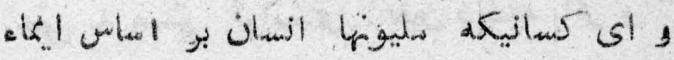

و اشلارة تان - ياراه ميروند و يا افتان و خيزان در

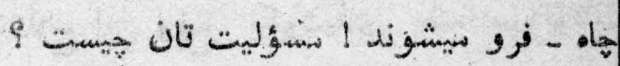

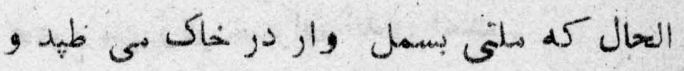

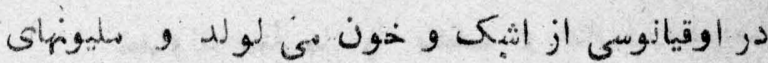

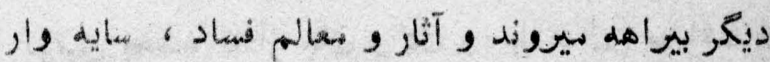

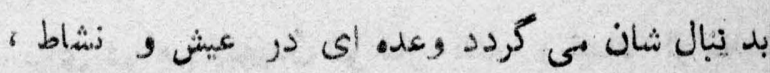

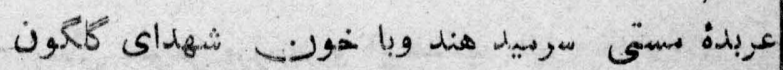

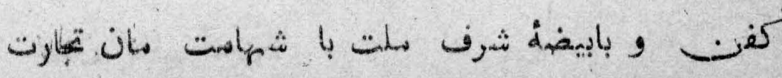


بروثيد و يالا اقل به اظهار "كملة حق" در مضر

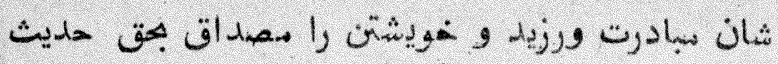

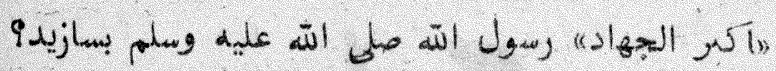

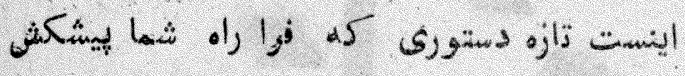

"اذا رأيت استى تهاب ان تقول للغطالم يا

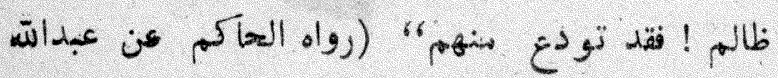
ابن عمر - وقال صجيع الاسناد)

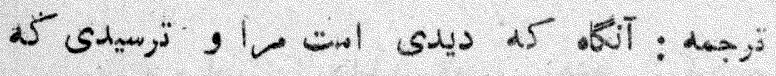
ظلالم را ظالم بكوئى (و به عذابى كرفتار كردى)

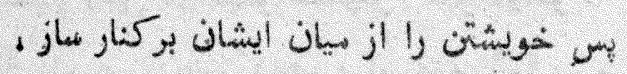
و اين است الرمان ديكرى از سر آسد برياسبران

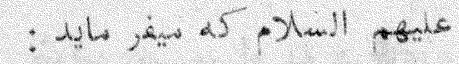

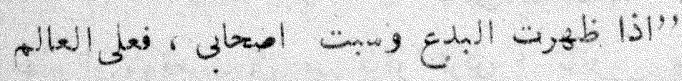

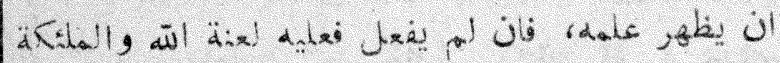

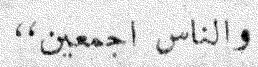

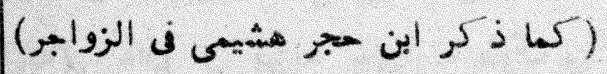

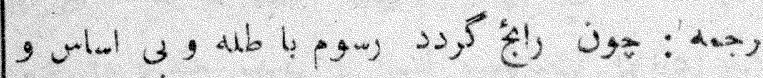

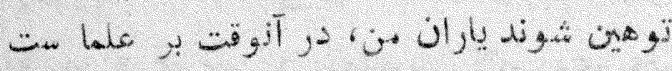

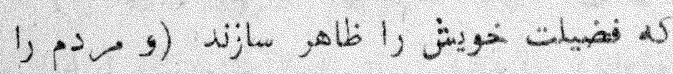

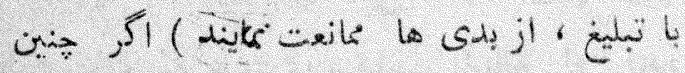

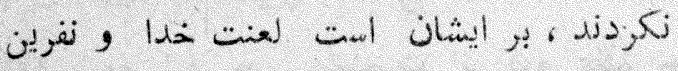

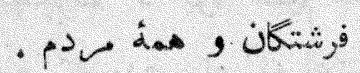

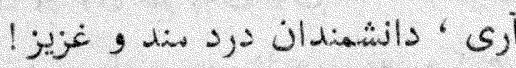
اين زنك كو شخراش خطر متوّجه شماست :

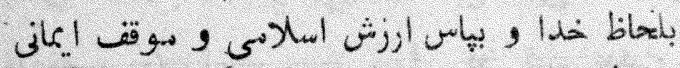

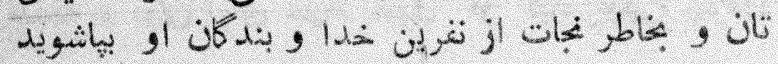

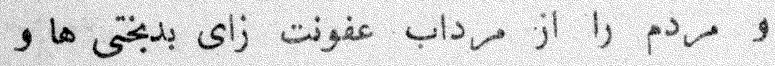

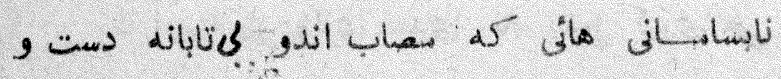

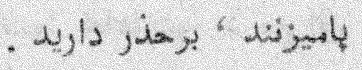

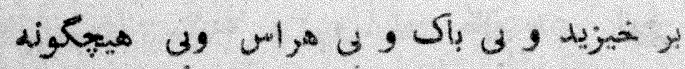

$$
\text { بق بقه در صفحة }
$$

ترجمه :" تسم بذاتى "يه نفس سن در تصرف اومت يا

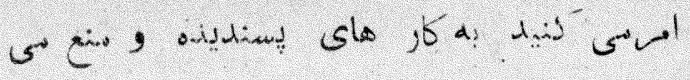

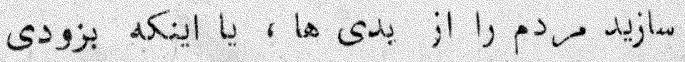

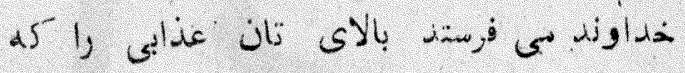

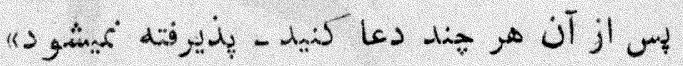

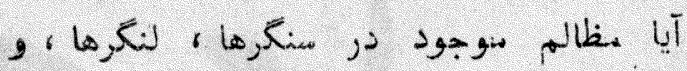
دفتر هارا و درد والم دلشكستكان آفات و تثقيرشذكان

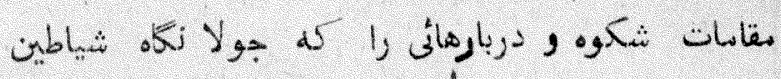

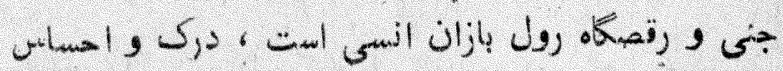
.

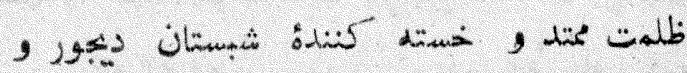

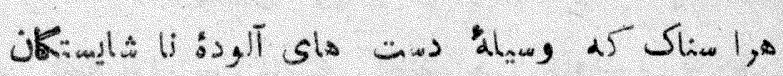

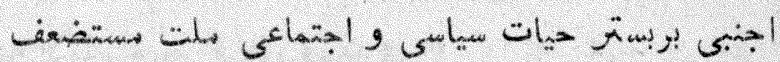

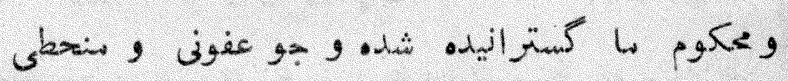

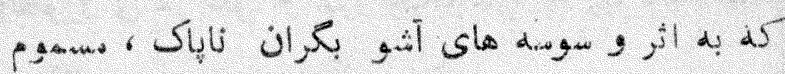

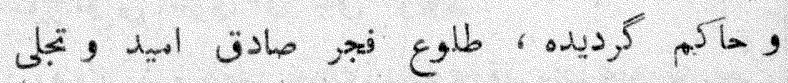

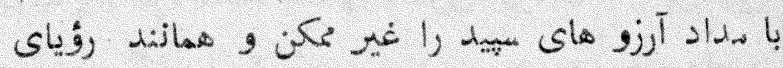

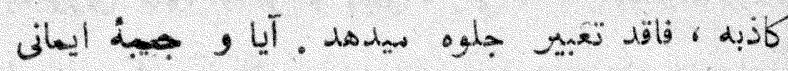
تان جه ايهابى دارد به

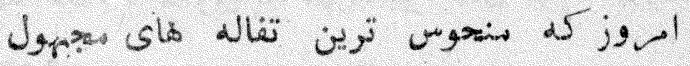

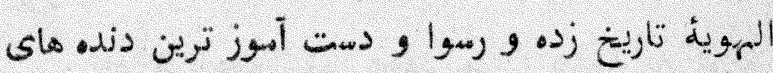

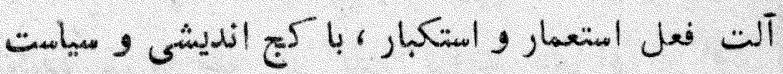

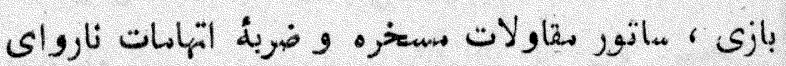
حويش را مصروف تحريف شضمون جهاد و تغيرنسير

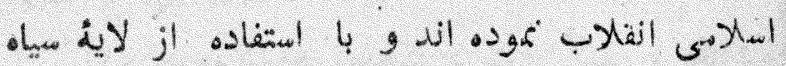

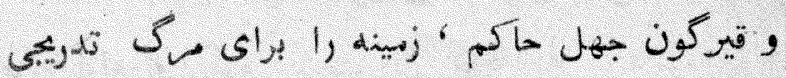

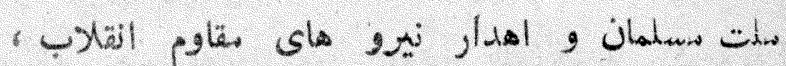

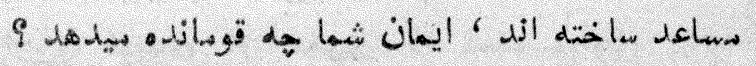

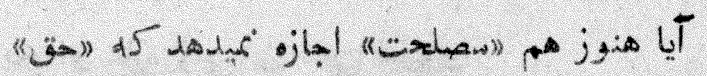

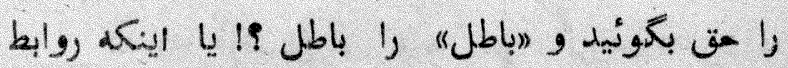

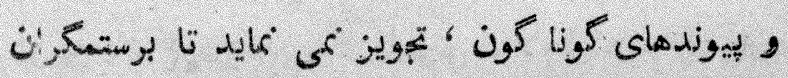



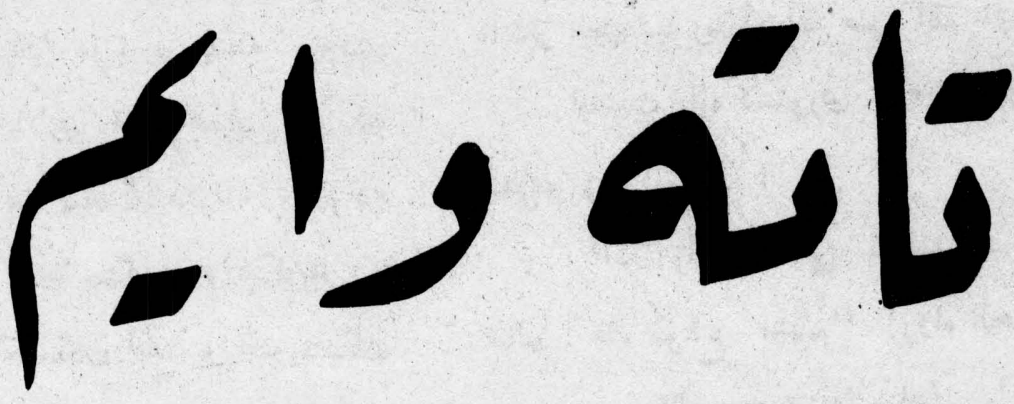

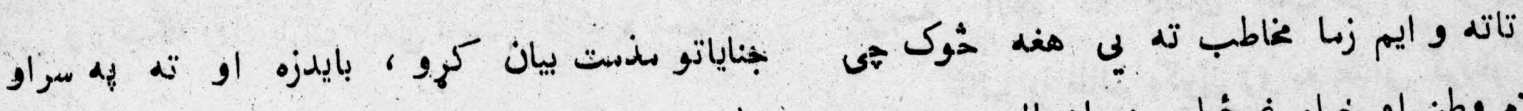

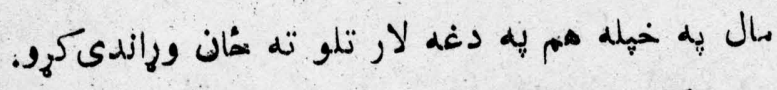

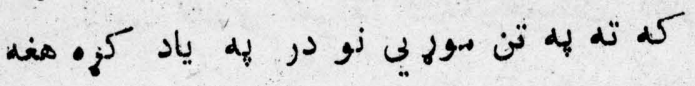

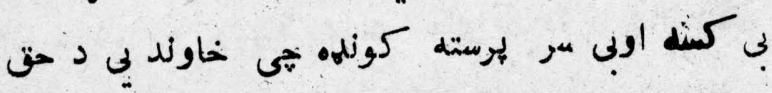

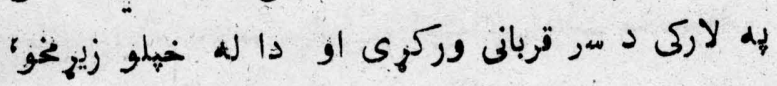

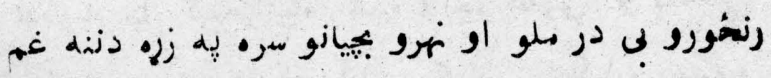

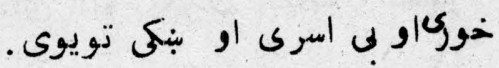

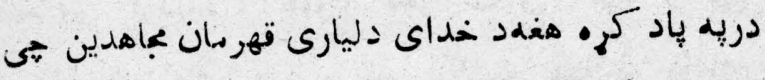

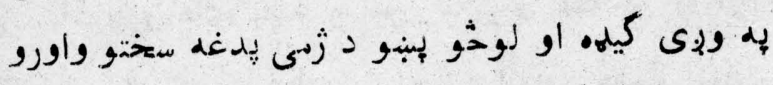

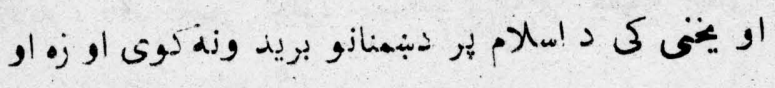

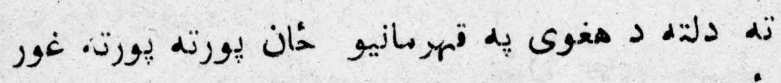
خو.

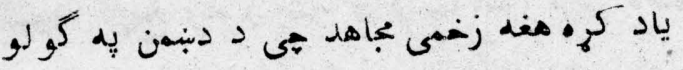

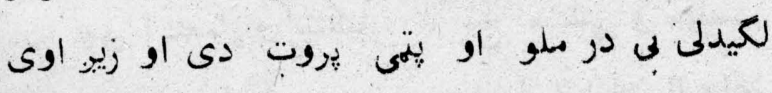

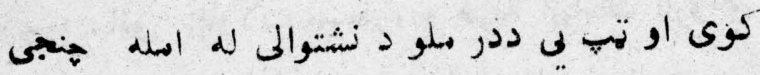

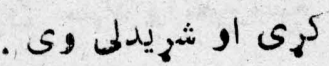

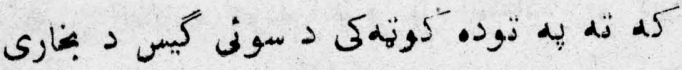

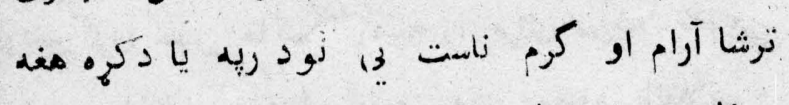

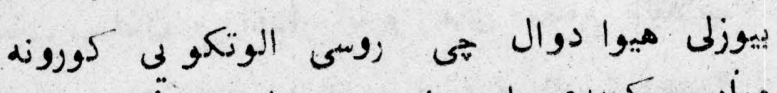

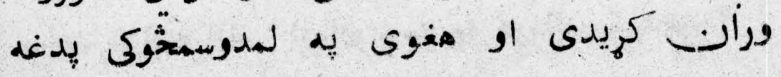

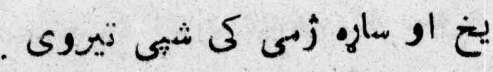

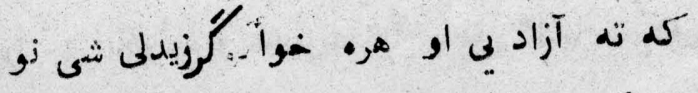

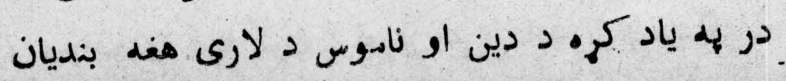

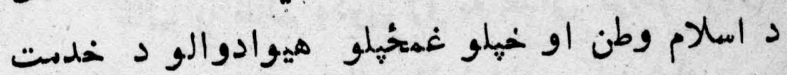

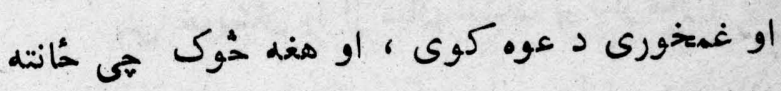

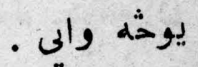

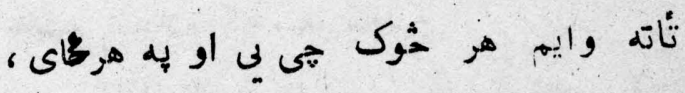

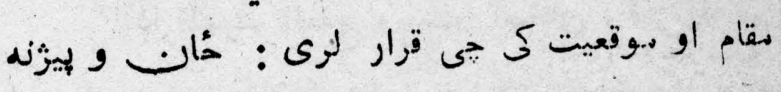

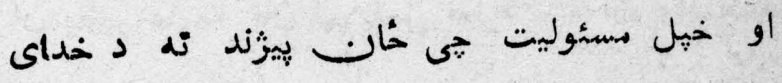

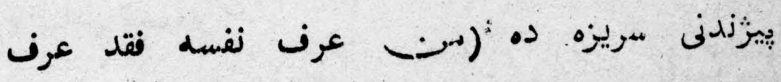

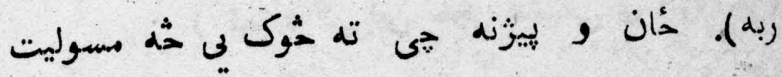

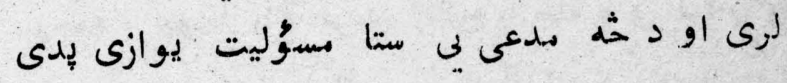

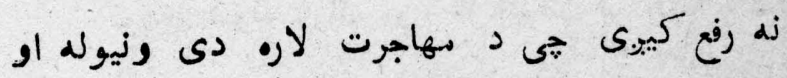

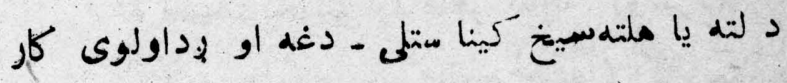

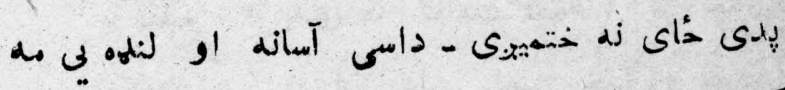

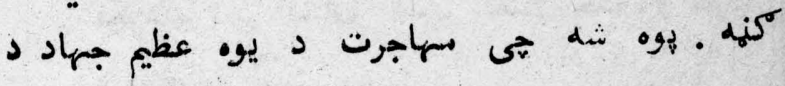

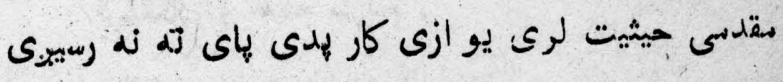

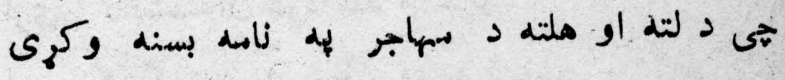

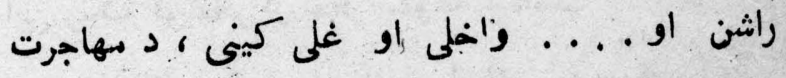

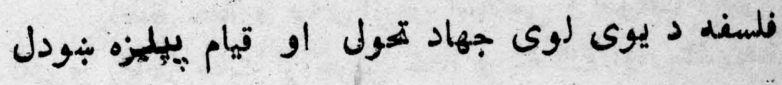
شويده

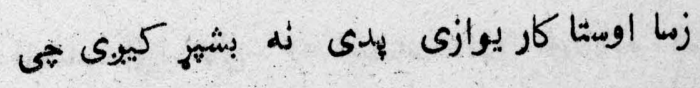

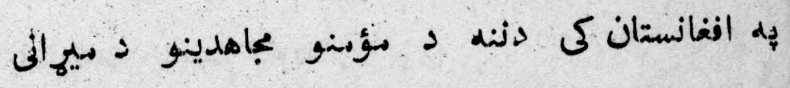

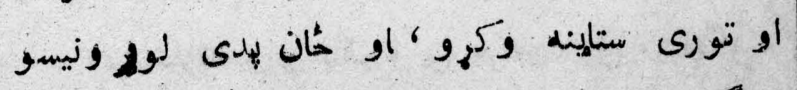

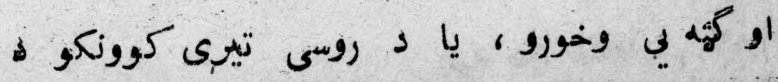




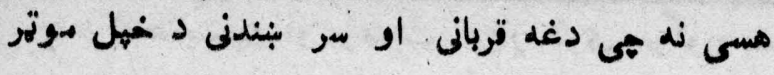

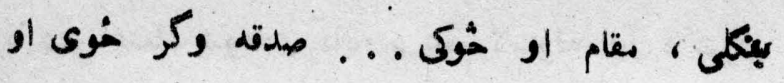

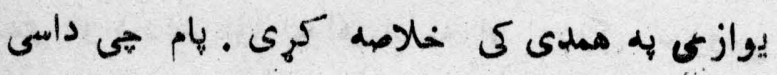

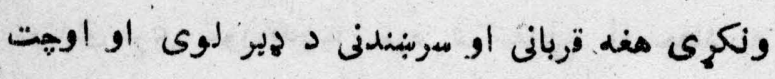

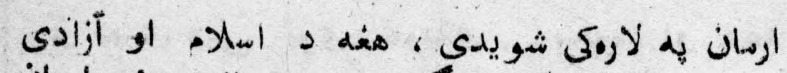

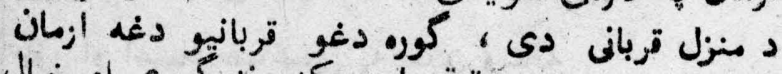

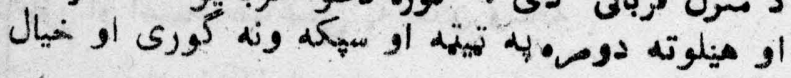

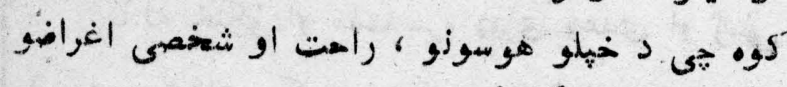

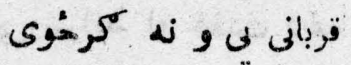

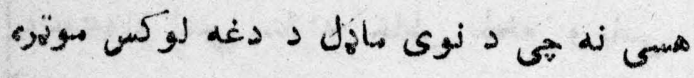

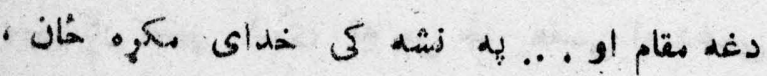

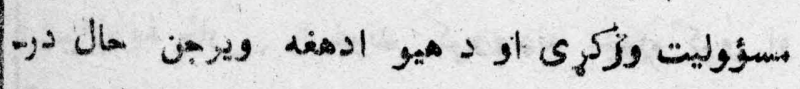

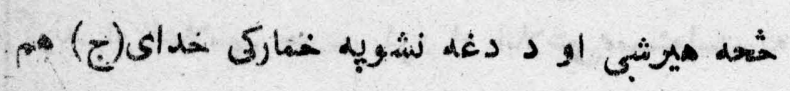

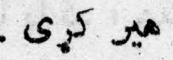

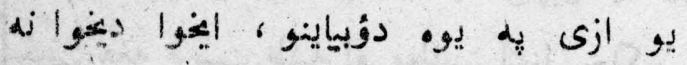

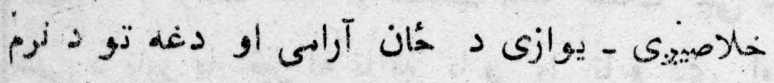

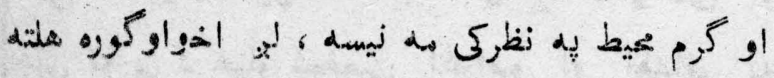

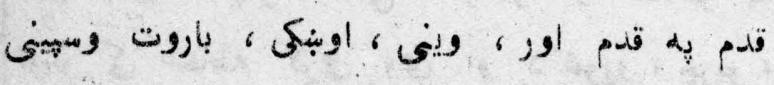

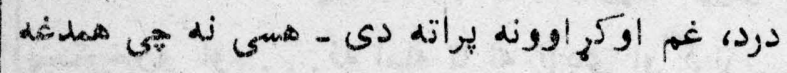

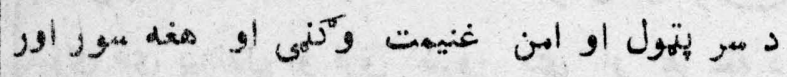

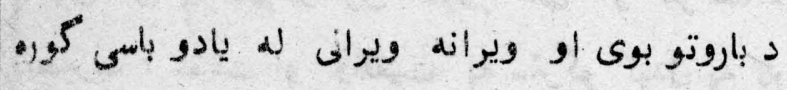

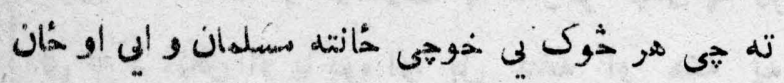

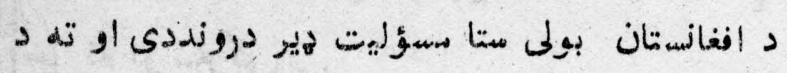

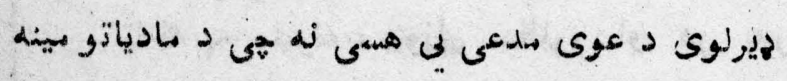

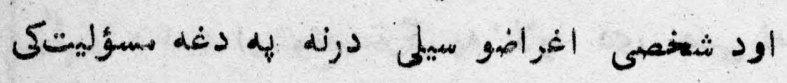

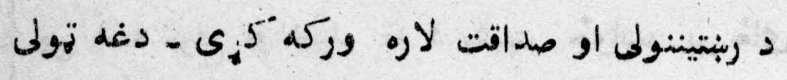

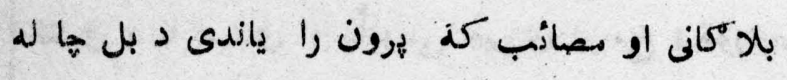

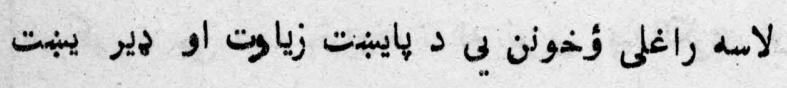

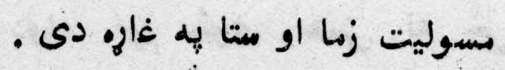

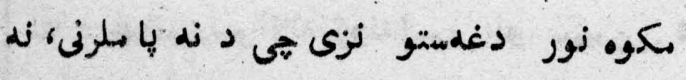

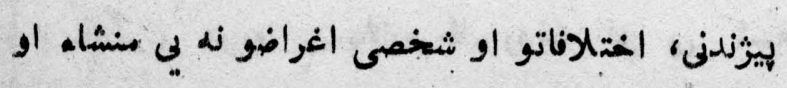

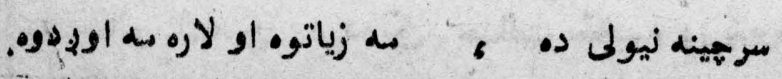

كوم هي يه وششتنا كو زندانونوكى تر برق هنلهو او

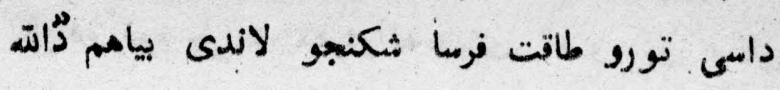

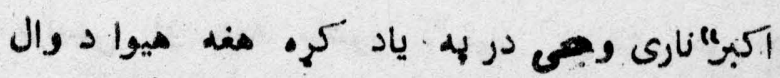

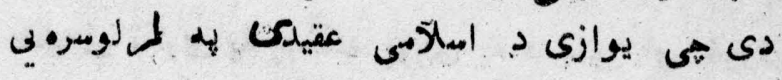

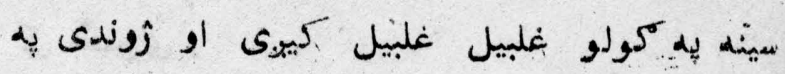

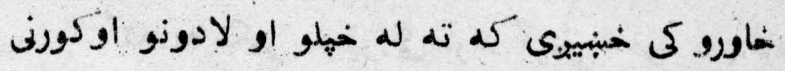

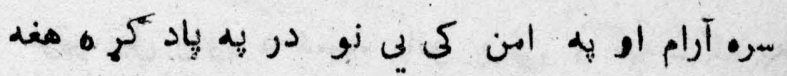

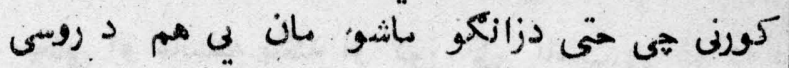

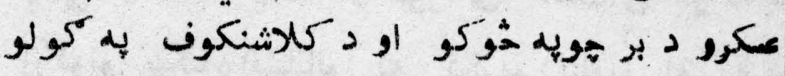

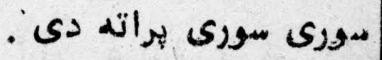

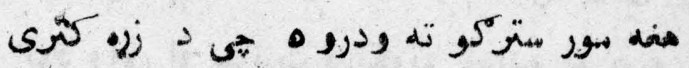

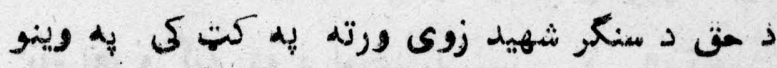

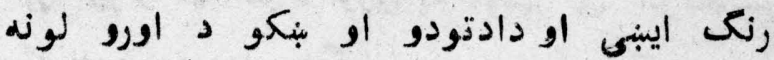

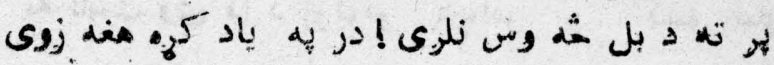

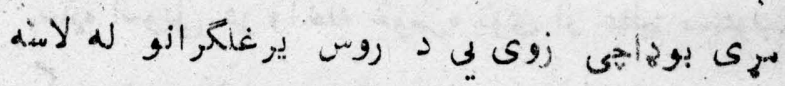

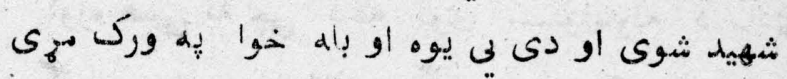

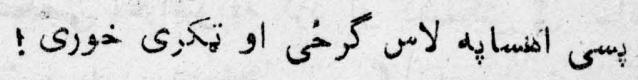

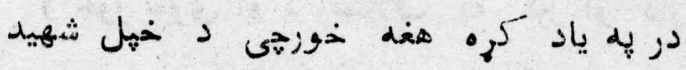
خوانيمرك ورور زيارت يه بنهو جاروكوى او يه اوبنكو هنه

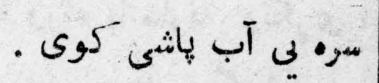

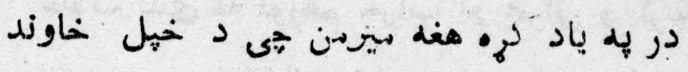

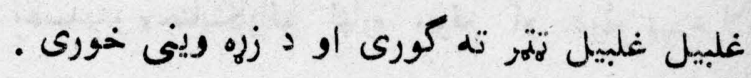

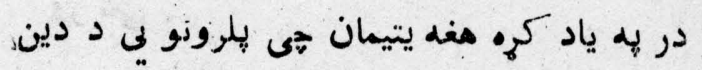

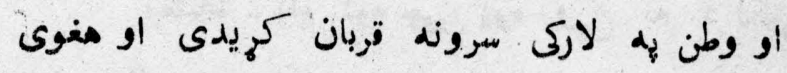

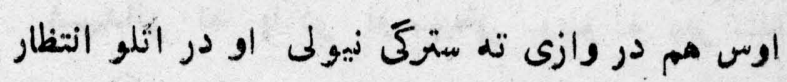

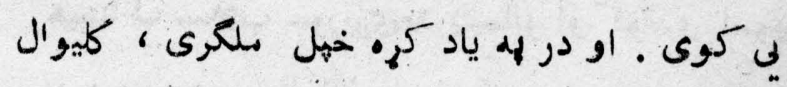

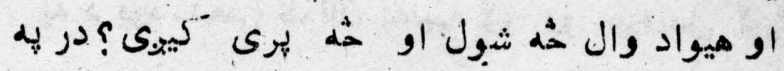

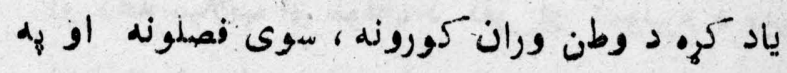

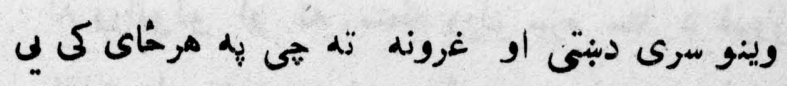

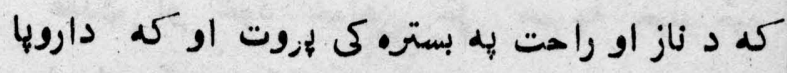

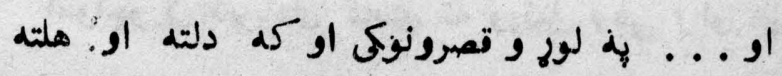

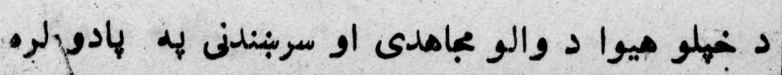


د مغل ماشوم او مور مال تل زوروه با بملرنهيه

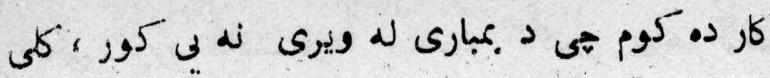

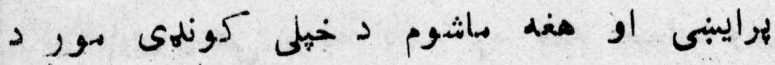

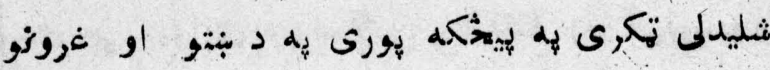

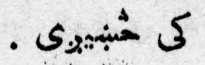

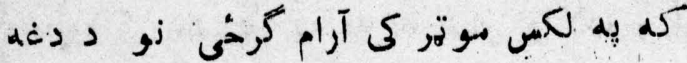

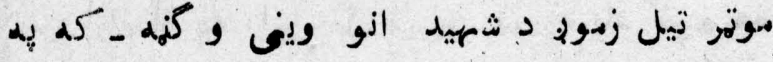

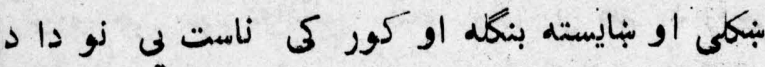

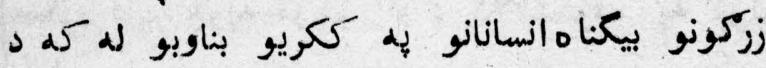

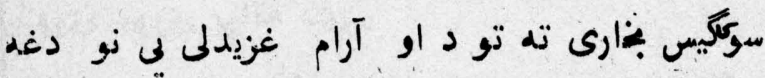
تود واله او هرارت د لكرنو كونيهو او بورو آه او :

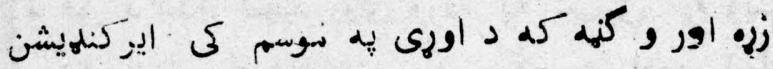

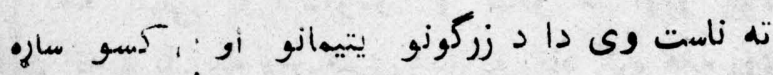
ساره اسويلى در واخله خومه لوى او عظيم هسئوليت

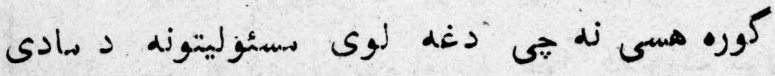

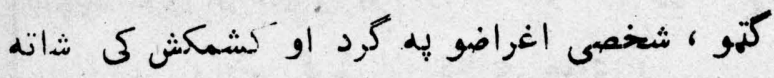

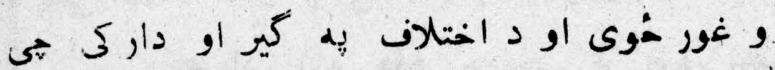

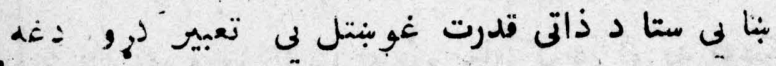

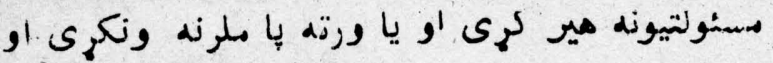

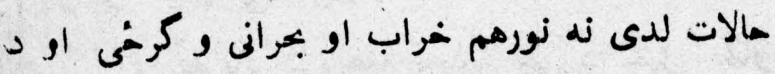

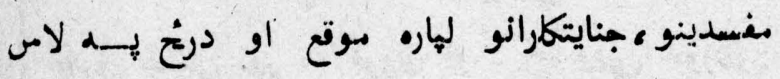
ور شى :

احتياط - بام كوه هيى يوه ورنخ به د لكونو

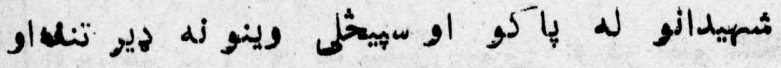

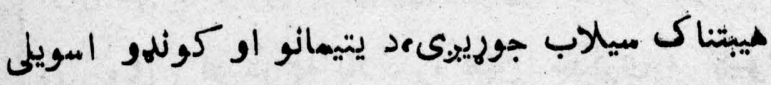

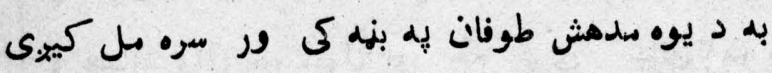

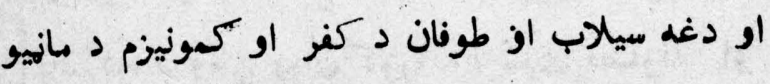

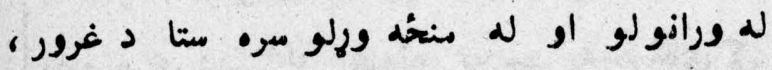

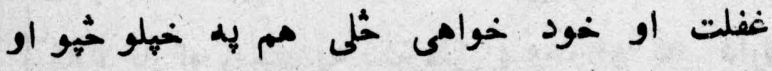
امتوابو كى دبربادى كندى ته ورتيل ومى ، او خهيله
كد د مشرى او زعامت وياه لرى نوكور. بي

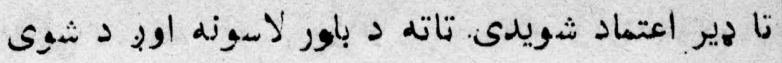

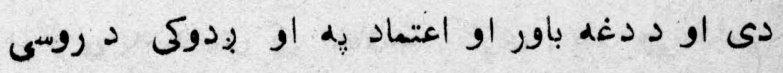
غوندى نزى خور قدرت سره د م.قابلى او جهاد به

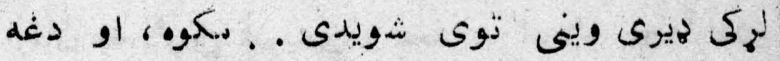

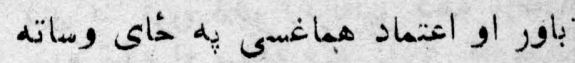

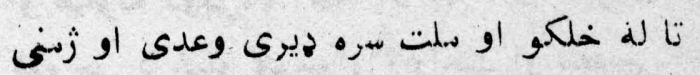

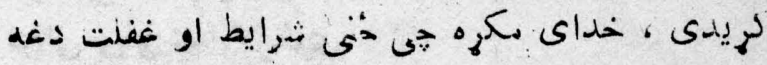

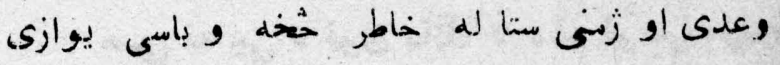

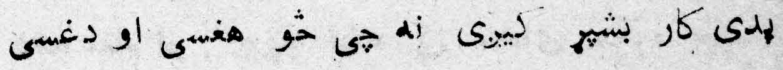

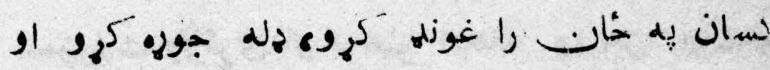

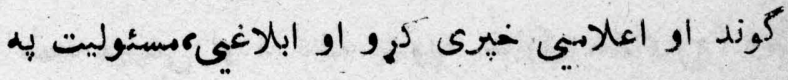

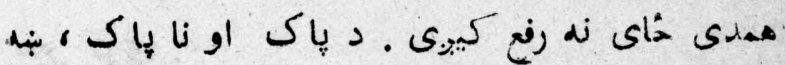

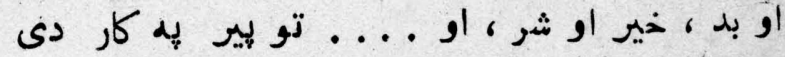

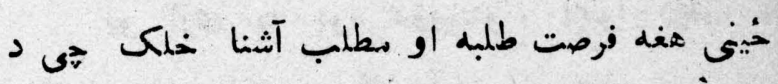

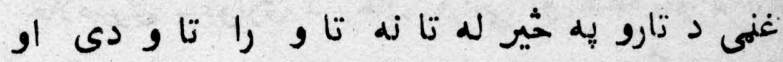

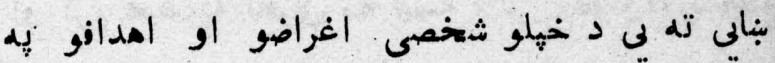

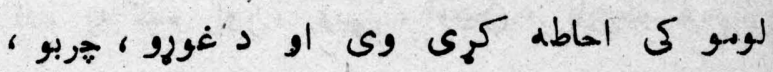

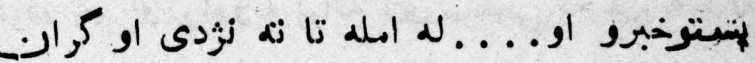
شوى دى ييزنليل او فرق ضرور دى او هر خه د

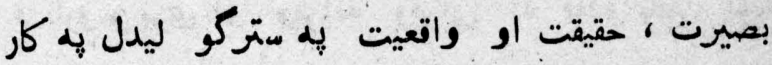

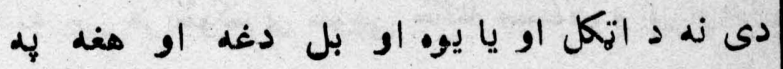

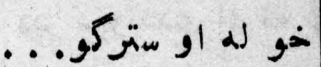

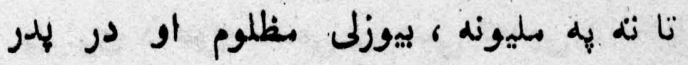

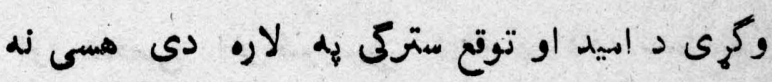

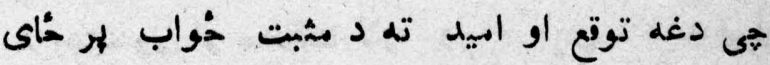

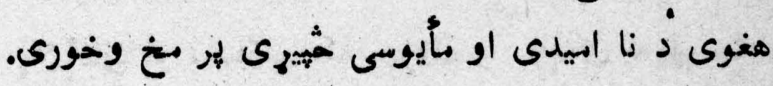

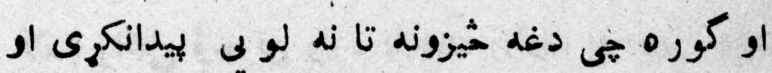

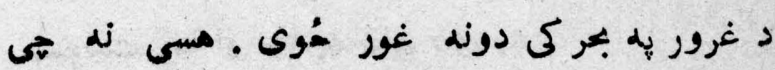

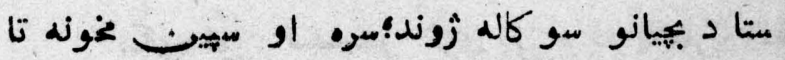

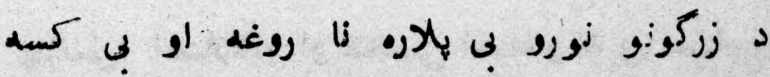

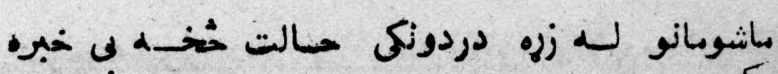




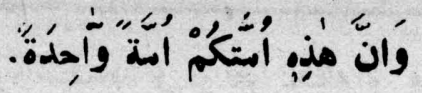

(

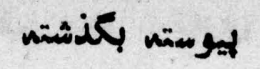

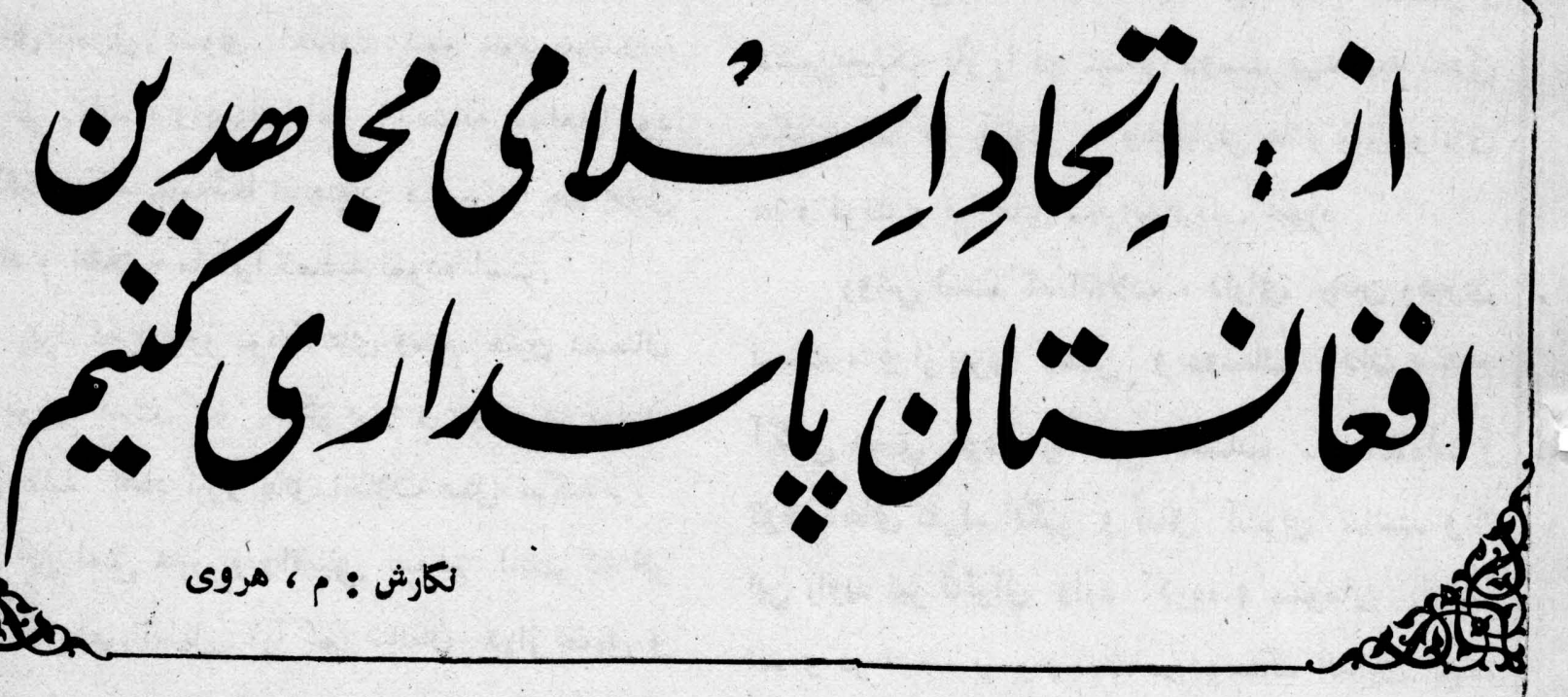

دز شاره قبلى ، كفتيم كه : "اتحاذه و هاختلافه" ، دو بديده از نمودمالى اجتاعى جو الع انسانى مى باشند

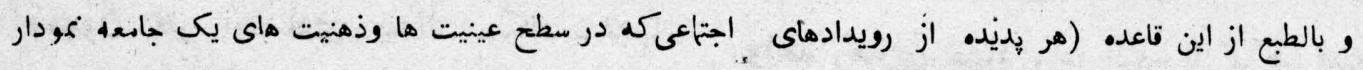

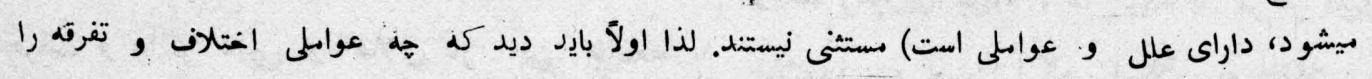

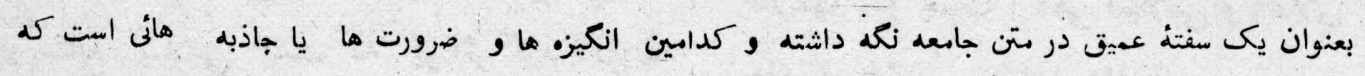

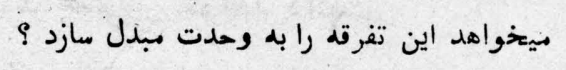

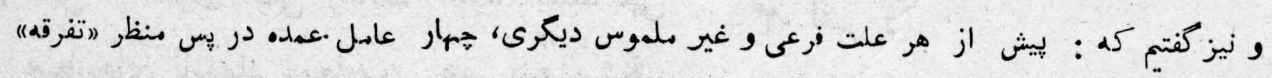

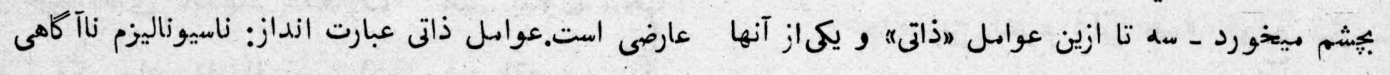

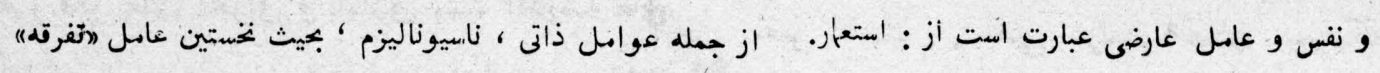

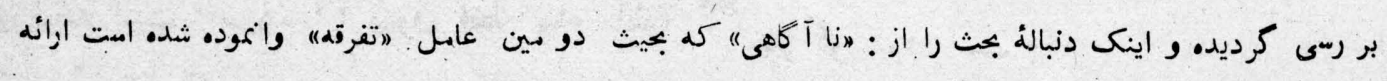

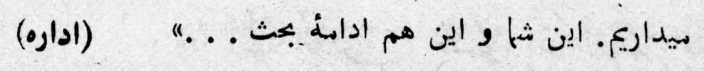

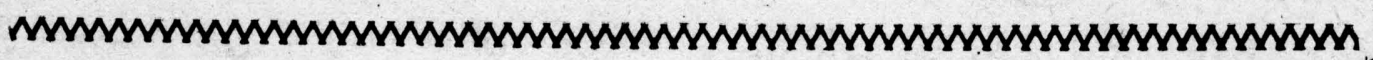

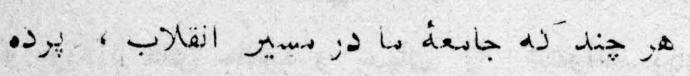

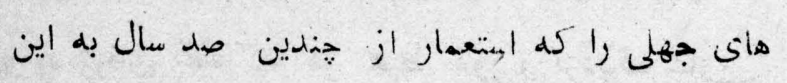

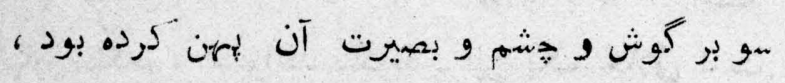

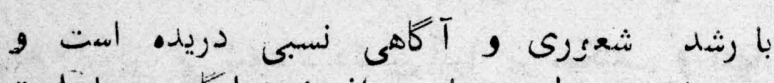

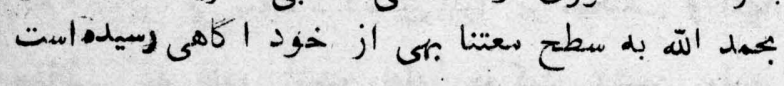

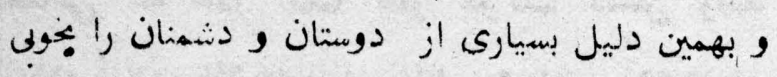

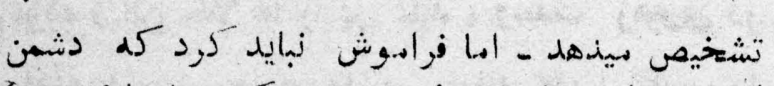

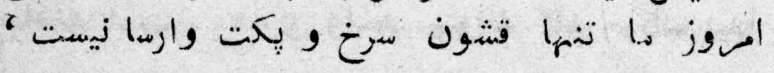

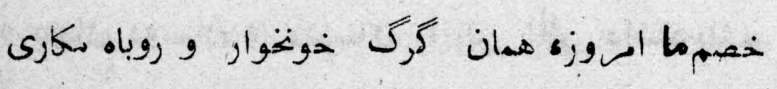

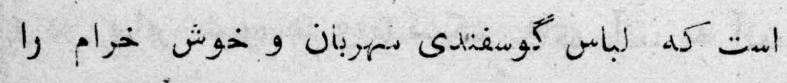

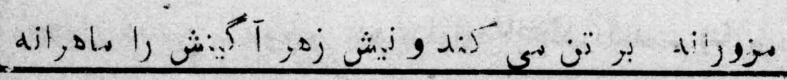
:

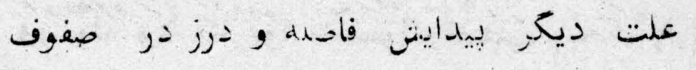

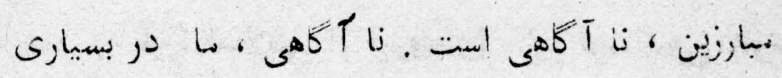

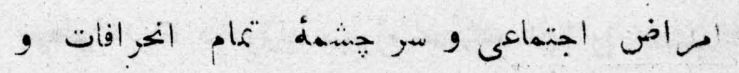

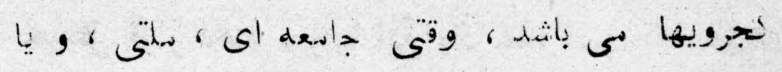
كآز

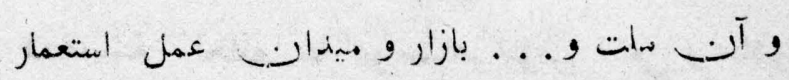

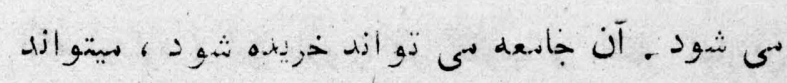

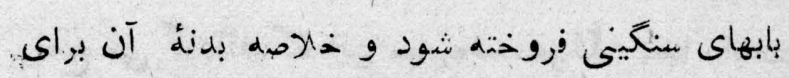
هذيرش هر زوع آسيب و آنت اجتهاعى ، سياسى و. . . آنساده استت 


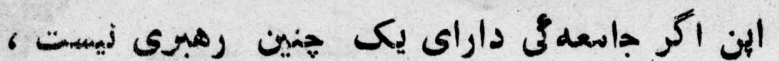

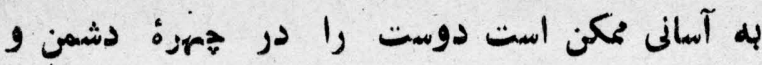
دشمنيرنًّ، باز را در سيهاى دوست ببيند، به سادكى مككن است به آرايش ها و ييرايش ها و زرق و برق ها و فوت و فن هاى مكارانه فريب بخورد . روشن است كس انقلاب ، داراى هينين رهبرى نيست ، و از ينزو دشمن و دوستان زادان ، عدم آكاهى عميق توده را على الحساب سير القاءات و

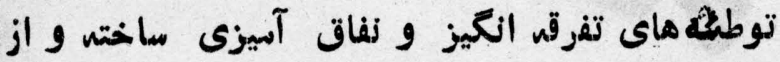

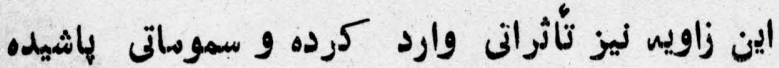
اند و در نتيجس برسر وحدت مردم سنع اندازى نموده

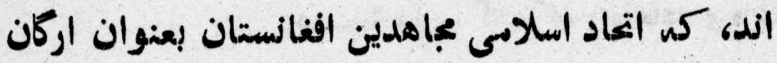
واحد رهبرى جهاد ، در آينده با تمركز قوى و تشديد

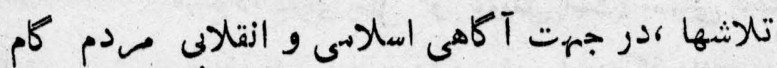

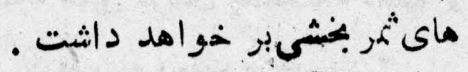$$
\text { r. }
$$

عمدهترين اهوم ذاتى همه انواع تشتتت و تفرقه نفس است . .. يعنى درست همان هيزيكه قرآن.

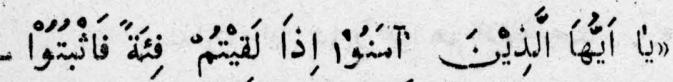

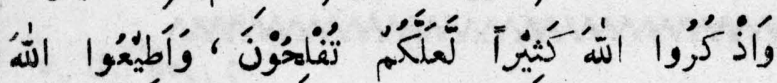

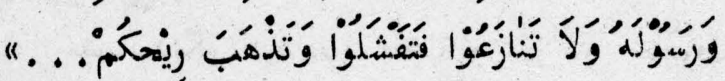
هبارزة السامى از زيروهاى زير فرماندهى خود ميخواهد تا در روند مبارزه هميشه خدا را نصب العين خويش قرار دهند - زيرا اين ياد خدا است كه حقيقت

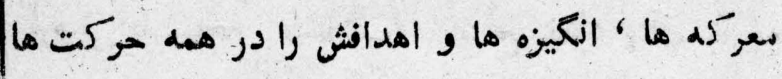

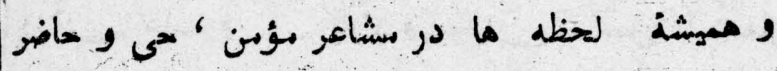

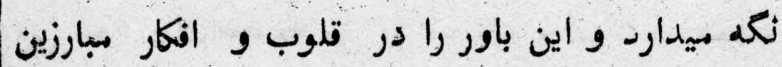

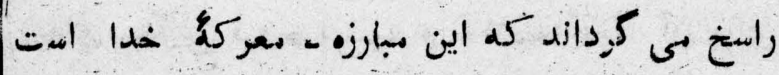

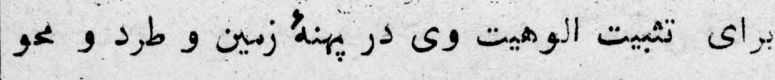

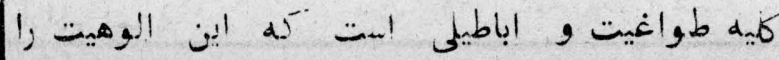

بو تنه انقلاب فرو سينهايد و از هر لحظله و هر فرضصت و هر بوتعيتى براه كيد ورزيدن و از قفا خنجر زدن

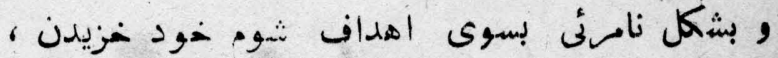
دريغ نمى نمايد ، و بسيار ساده الديشيانه خواهده بود

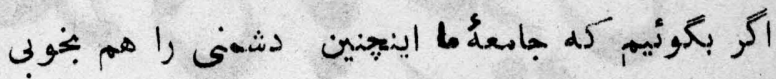

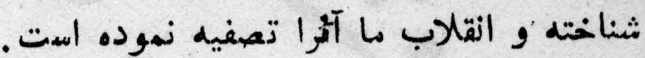
زيرا كه امسوز توطله هاى وسيح همين دشمنان نقاب يوش امت كم بشكل يِيدا و يُهان دز سيدان "نفاق"عليه اتحاد زيرو هاى انقلاب عمل ميكند . اين اصلى مرز و واقعيتى دسلم الهت كه فقر

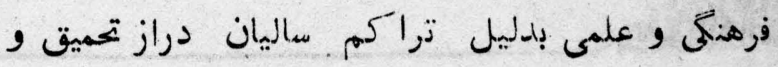
استحمار رزيم هاى انتسانى استعهار ‘ بركل بيكرة مليونى

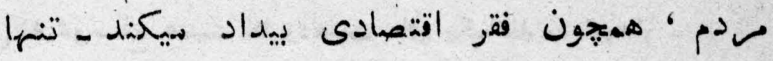
بايخاه معرفت و دانش دينى و انقلاكى در اين جانسعد

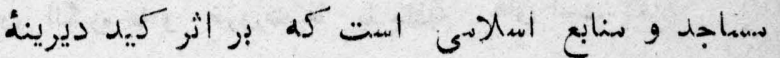

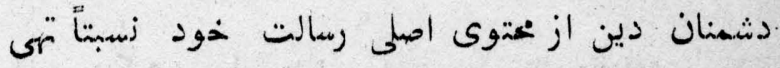

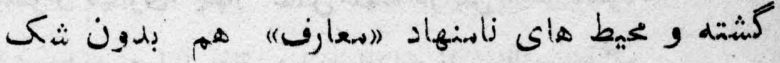

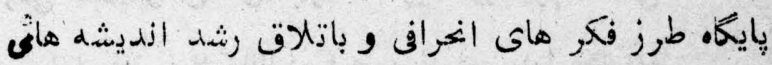
الحادى بوده است ' مردم ، اكنون فقط بنام "الهّه"

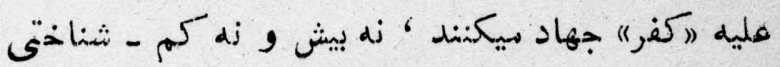
عبيق از اسلاسات اسلانى زدارند ، مسائل - جريانات و رويداد هاى جاسعه و جهان ران نميتوانيد بكوند ، و به زرفاى آنهج كه در ميط دور و نزدينى شالن. تبارز ميكند ، نميتوانند بنكرزد ـ اين يكى خلانئ است

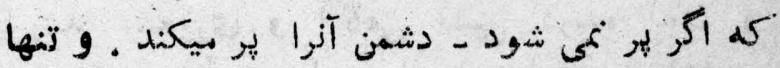

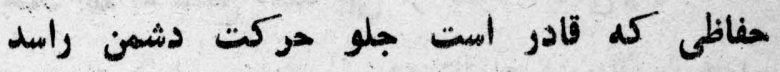

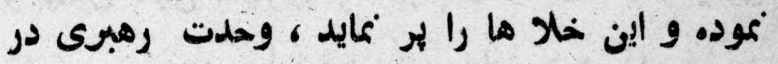

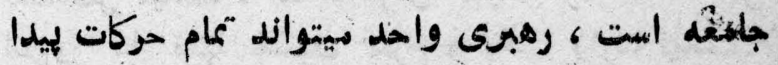
و بنهان دوستان و دشهنان را زير انطر د داشته باشد و در برابر شيوه ها و تاكتيك هاى هآ آن به آن

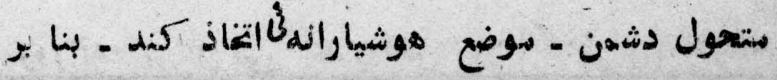


خودش در آن مسائل روشن باثده - اين هوى "نفس"

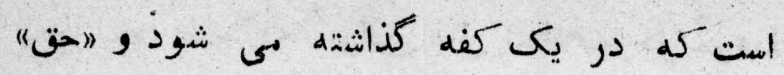
در كفل ديكز، و بيكسان آن نفس است كله له ترجيع بيدا نمى كند. ن.

بدون ثكل مسكز ثقل اختلاف و تعدد كروهي

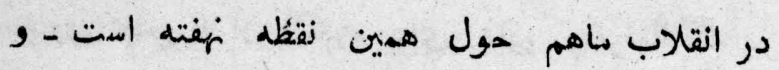

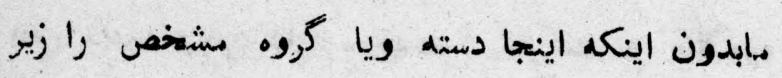

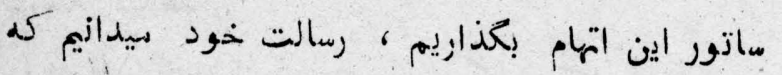

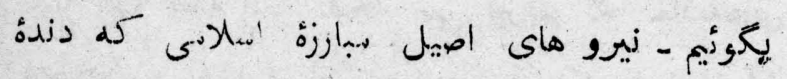

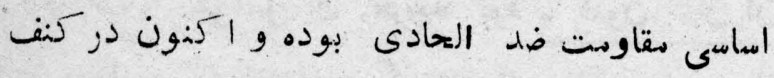

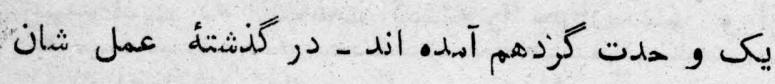

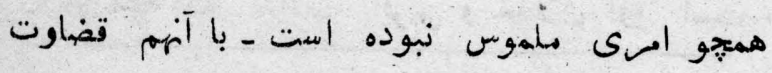

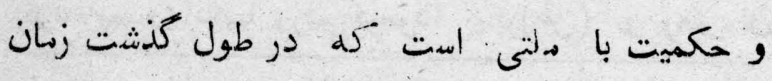

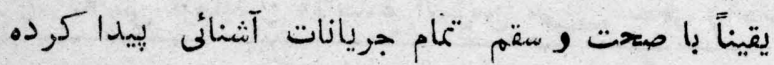

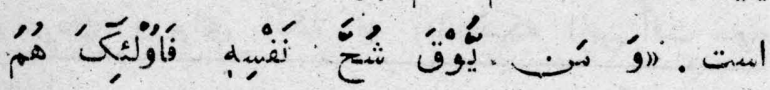

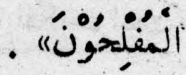

الستعهار المعلوري

از عوامل ذاتى اختلاف كله بكذريم - طبيعتاً

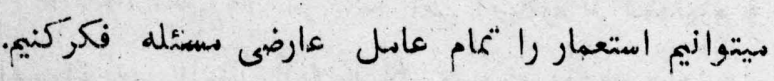

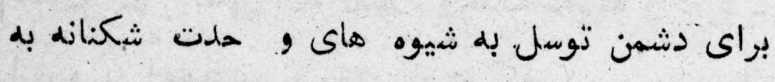

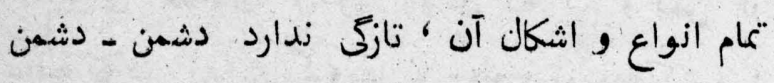

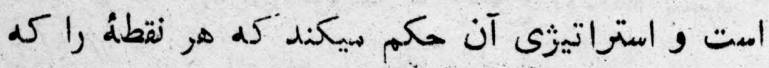

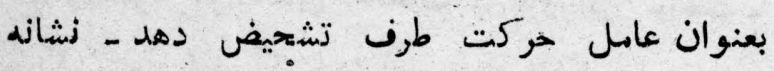

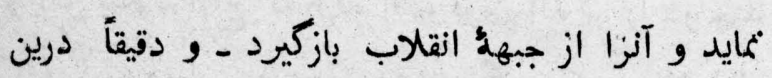

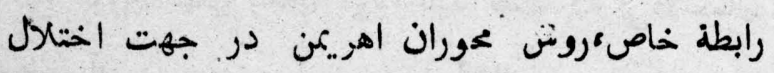

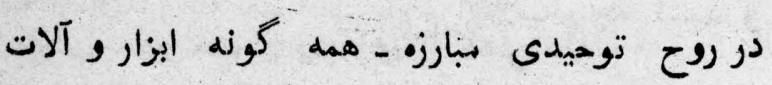

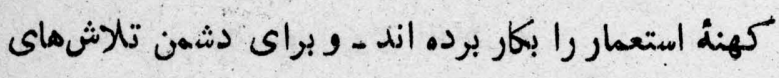
بياني ولا ينقطع در اين محور به اين خاطر دلعرم كنيند.

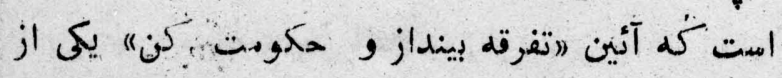

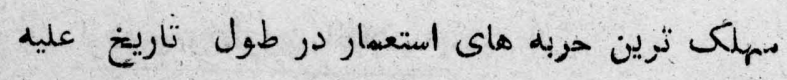

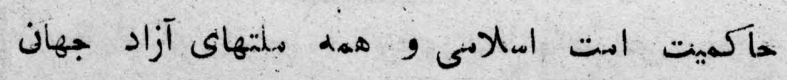

غصب كرده اذد . جنك ـ ـ جنى قدرت ، سيطزر

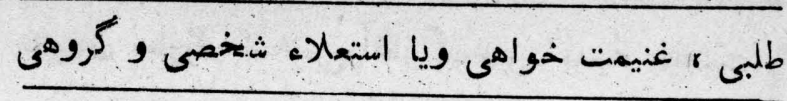

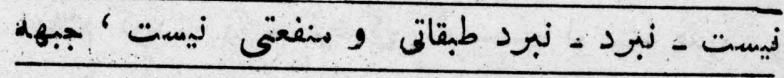

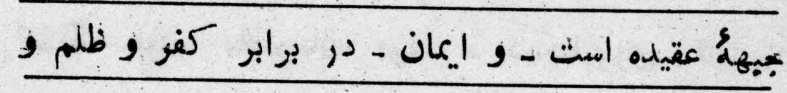

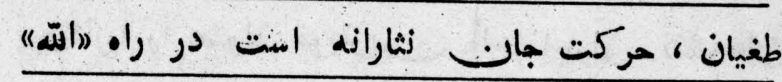
و در جهت سلطنت مطلق وى ...

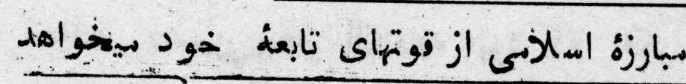

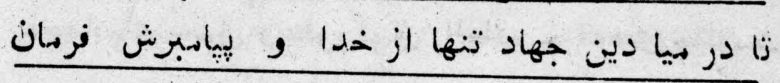

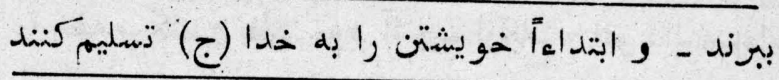

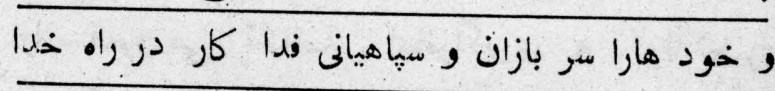

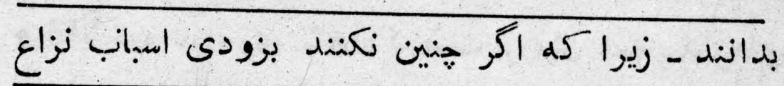

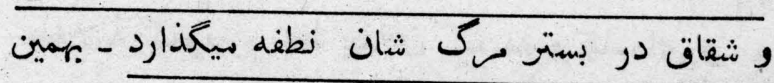

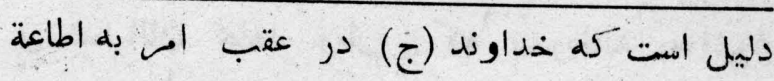
اله و رسول از نزاع و اختافلف در مسيه مبارزه ستخن

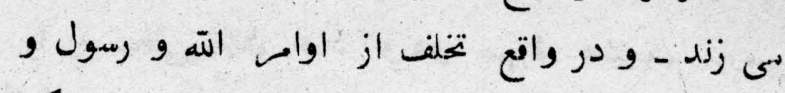

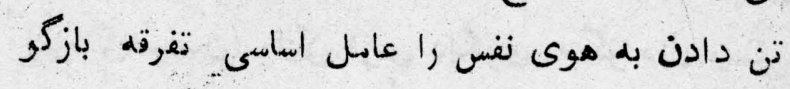

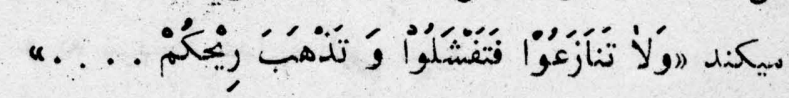

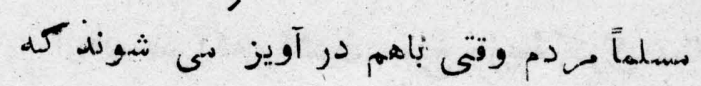

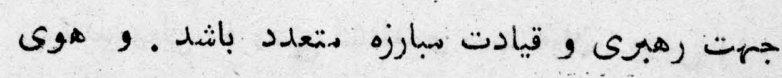
و هوس و بالثأخره منافع "!" مـطاع دطلق قرار بكيرند

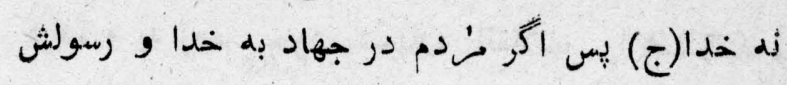

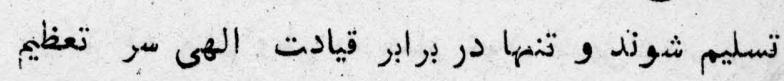

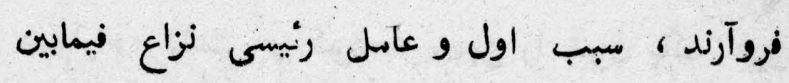

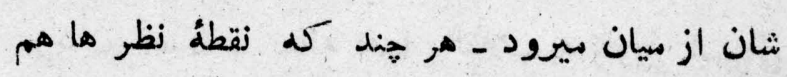

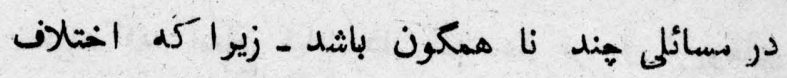

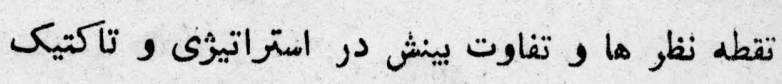

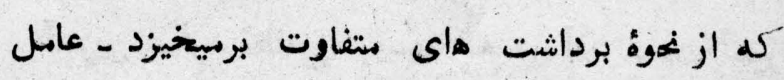

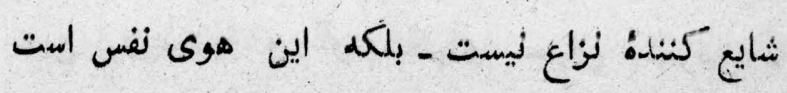

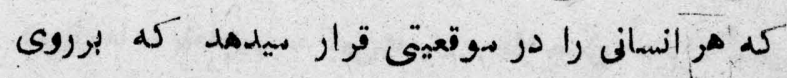

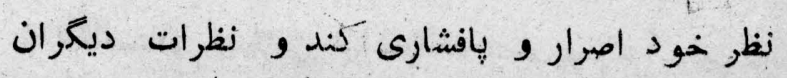

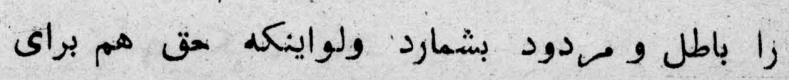




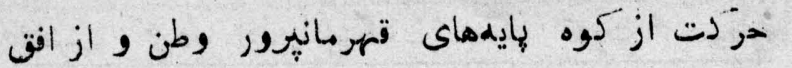

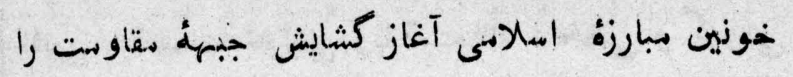

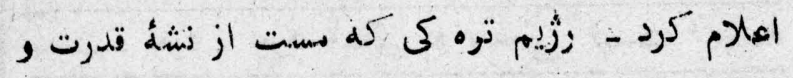

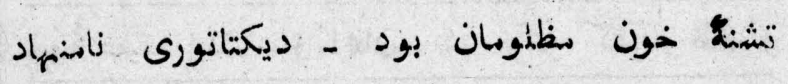

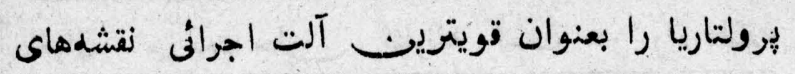
ستكوبكر - براى عقيه نمودن نهضت كافى سى دانست.

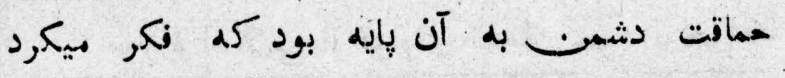

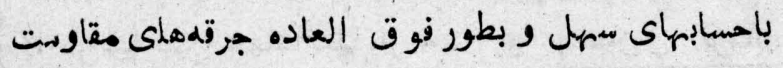

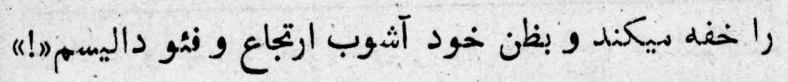

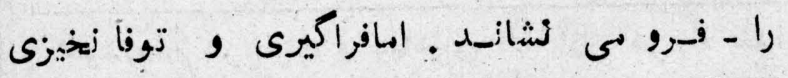

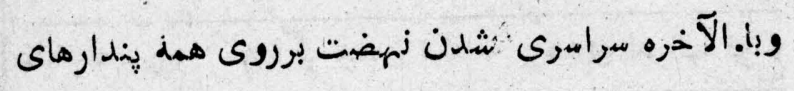

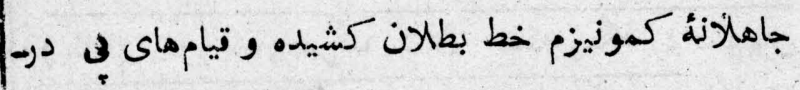

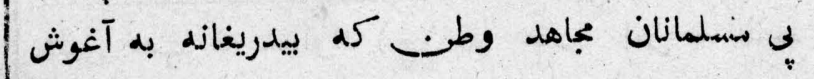

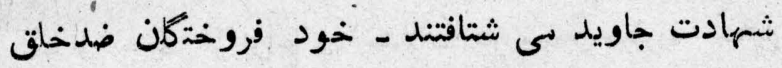

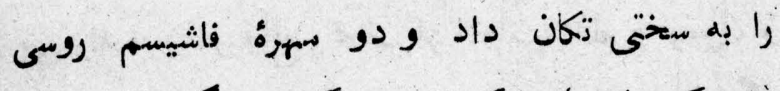

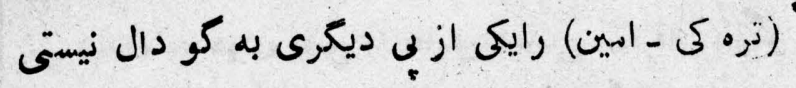
و به سروينجة عذاب الهى سيرد .

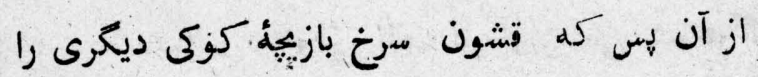

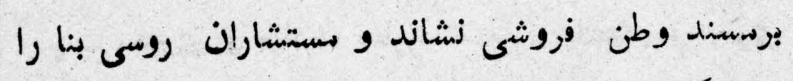

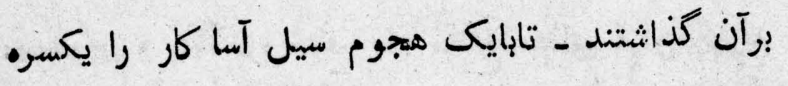

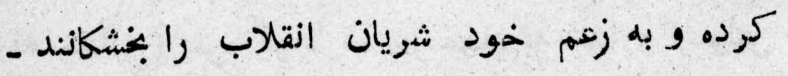
ديديم كم هنان وطن به حمام خون تبديل شه - در و ديوار و دشت و كوهسار ميهن را خون باكى ثير

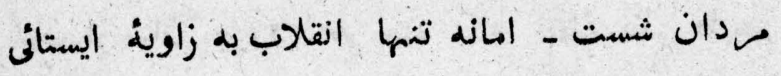

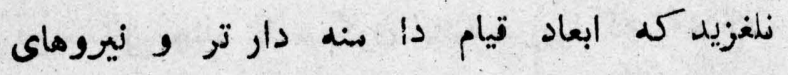

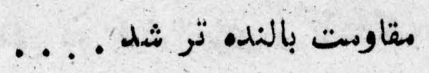

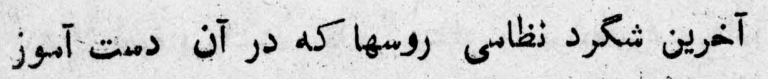

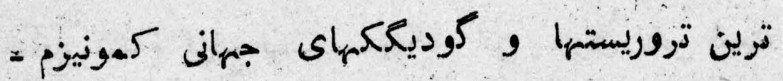

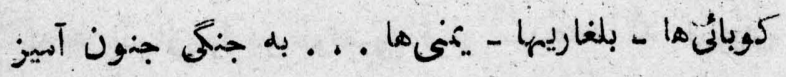

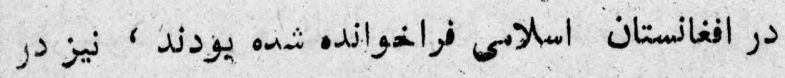
جرأبر نهضت شكست خورد م . . . .

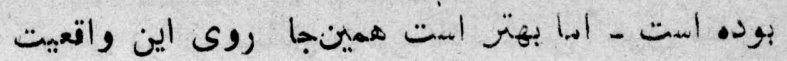

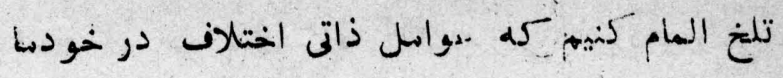

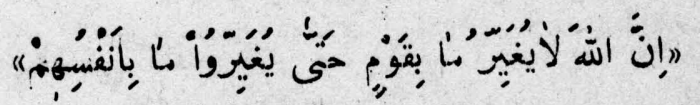

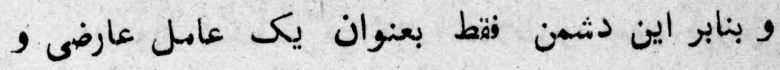

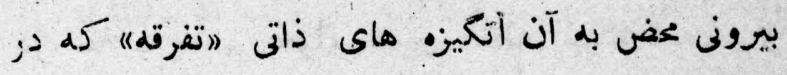
بطن جامعه وجود دارد - جهت ' حركت و و بالآخره

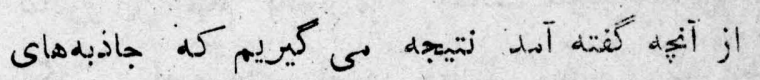

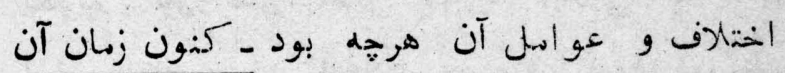

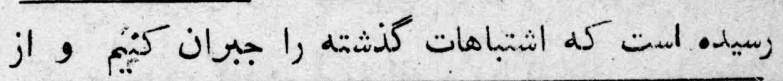

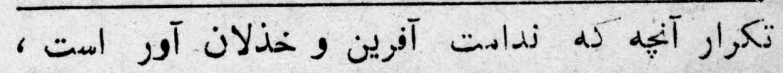

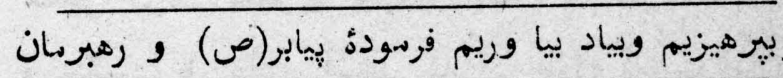

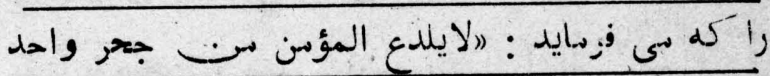

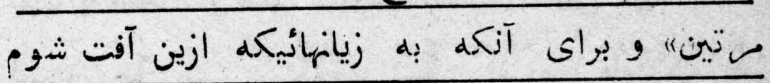

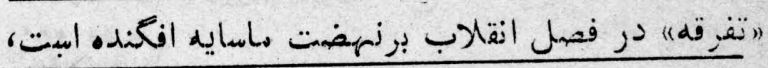

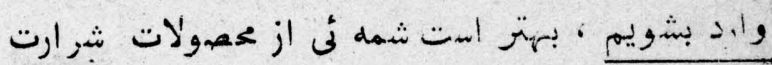

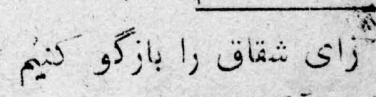

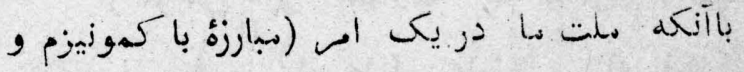

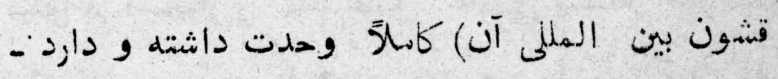

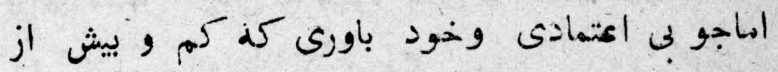

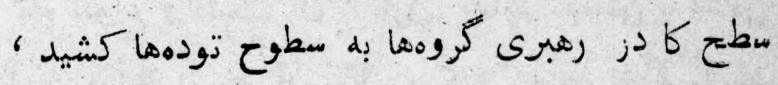

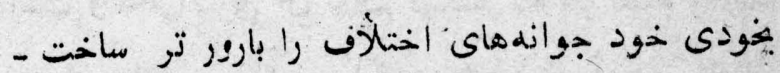

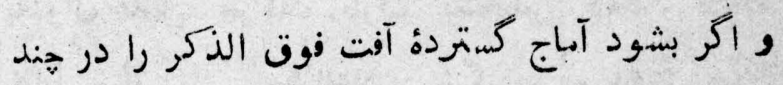

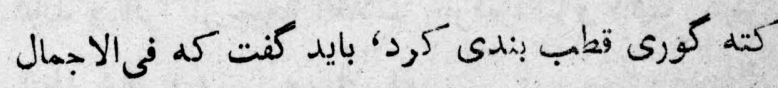

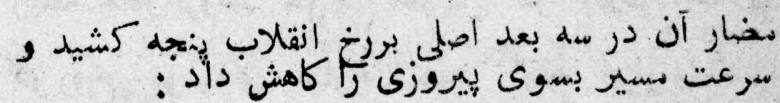
- اردوى رويا. روى انقلاب. - r - r - r ا- إردوى روياروى انقلاب :

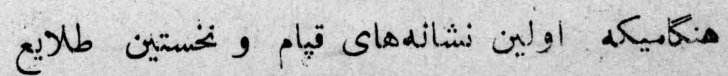


و خط سازش را عنوان مى كنيد - و بأ يقين كانل

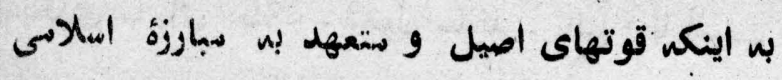

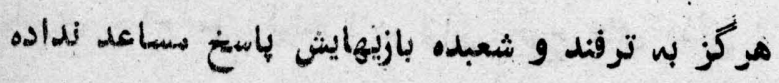

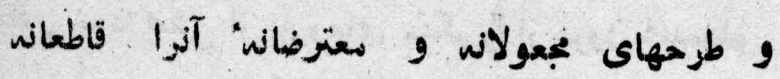

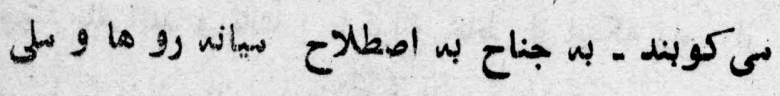

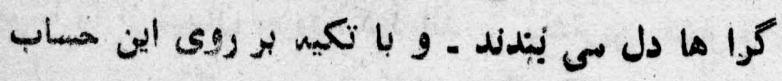

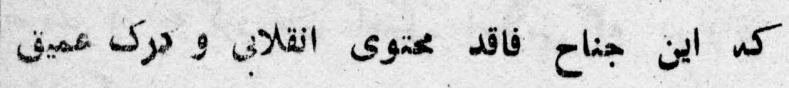

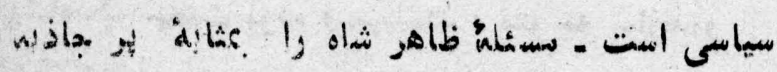

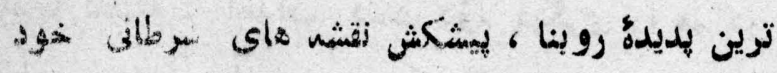
مى نمايند

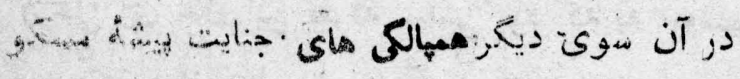

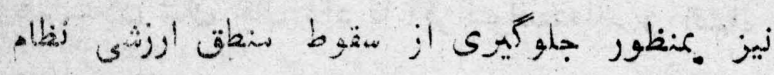

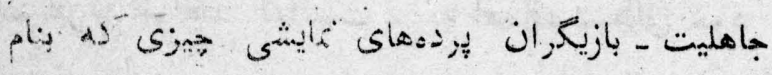

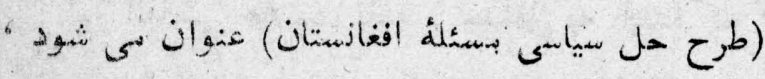

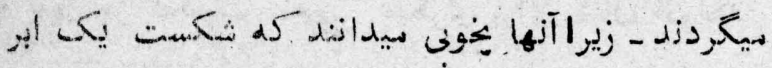

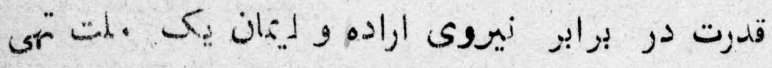

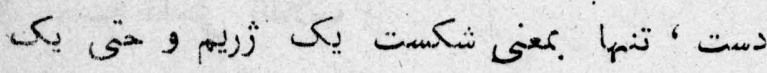

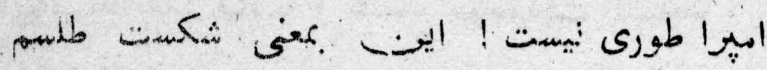

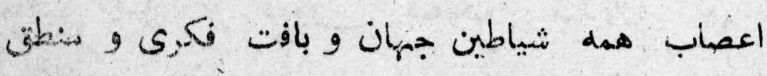

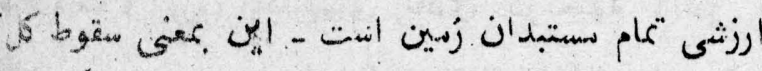

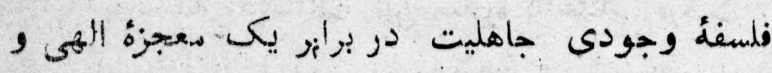

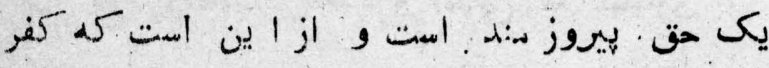
جهانى برأساس قاعدة (الكفر ملة ولحدة) نميتواند اين اين

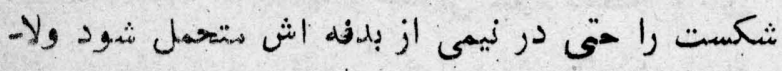

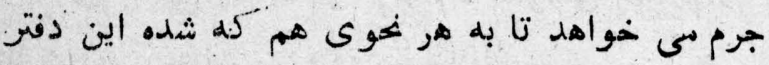

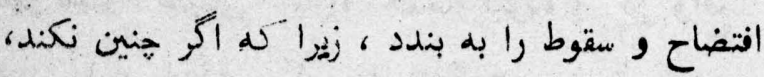

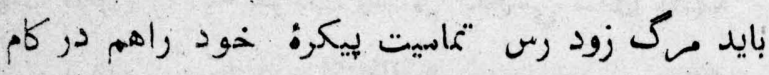

توفان خيزش جهانى اسلام شناهد بإثده !

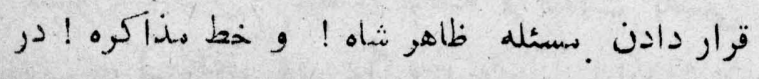
كانون خورا بهاى تبليغاتى جهان جاهلى، ناشى از وجود اين امبيد وارى امتكمبا اين كر خو اهند توانست اولاًا :
اينجا است كله روسها اذعان ميكنند كم صوفا فشار

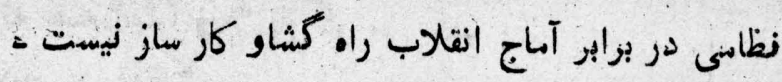
ورق برميكردد و روسها به كمى حلقه بكوشان خويثل به +. شيومهاى ديكر متوسل منى شوند.

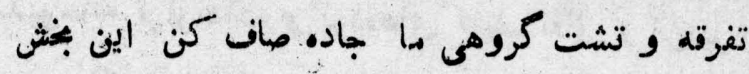

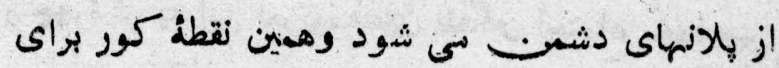

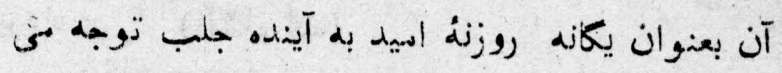

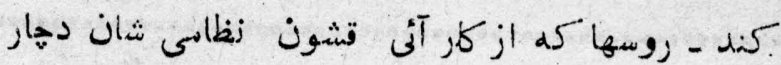

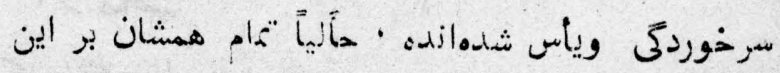

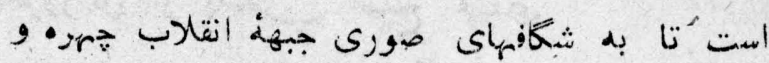

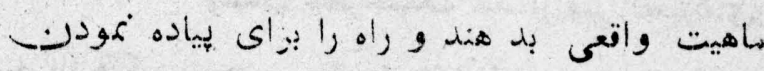

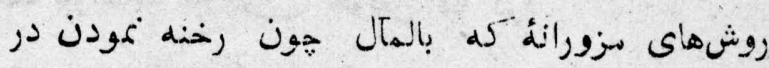

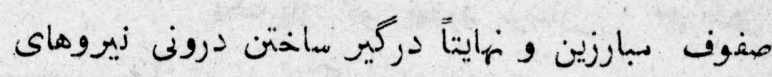

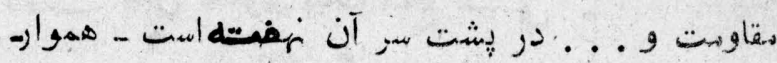
تر سازند .

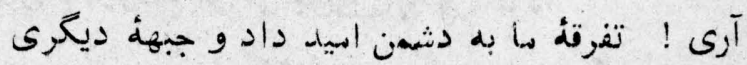

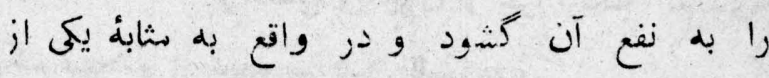

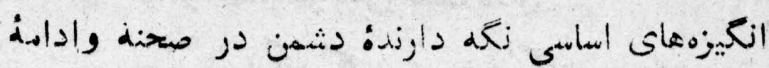
انشغال نظاسى عملاً عرض اندام كرد . . . . .

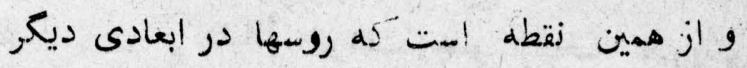

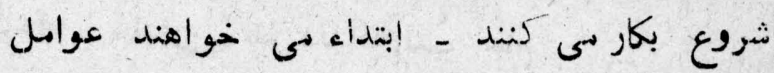
نفوذى شان را در جبهات جهاد سأسور عملى نمودن

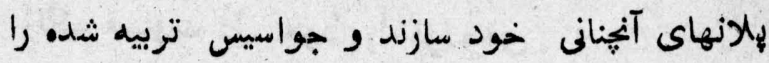

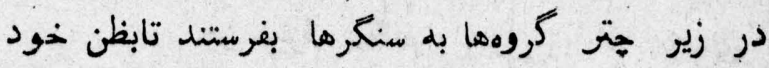

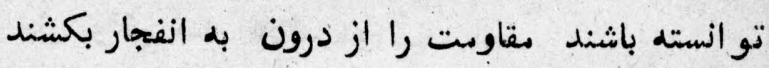

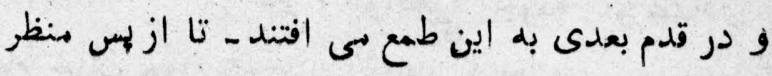

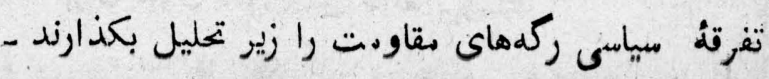

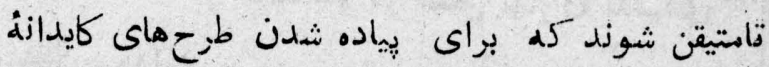

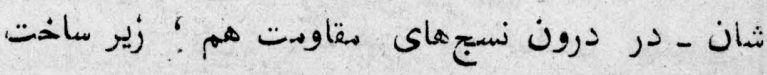

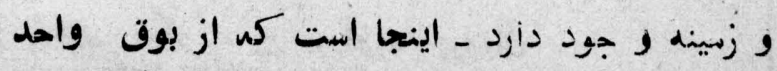
اسيرياليسم سياسى ! صداى مذا كره و آئن ;معاماله 
بطور اجمال بعضى از سوارد اين بهره برداريها والبته

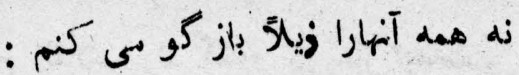

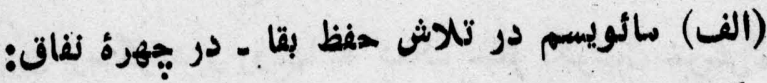

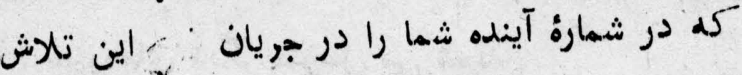
مذبوهانه قرار داده و بردههاى كثيف نفات و تزوير را

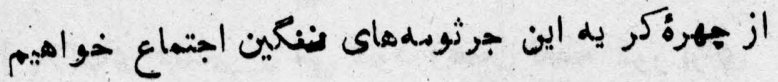

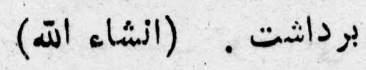

اخ

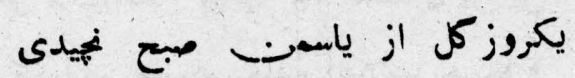

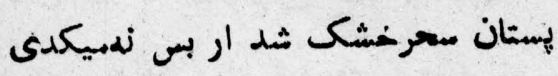

امد بار فلك ليرهـــ خويش قبا كرد

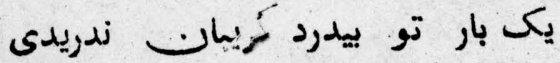

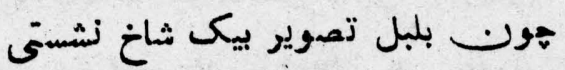
ز إنسردكى از شاخ بشاخى نهريدى

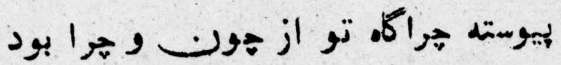

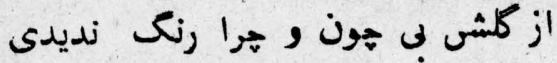

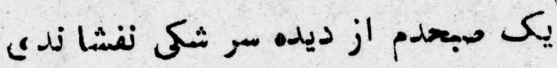

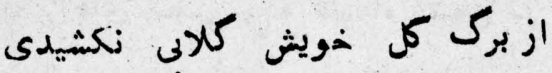

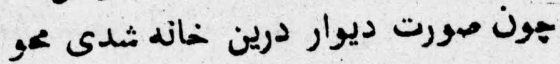

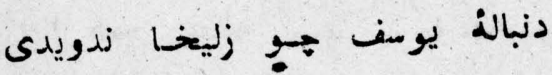

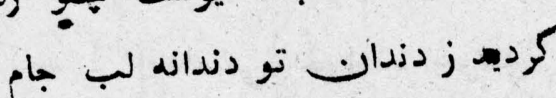

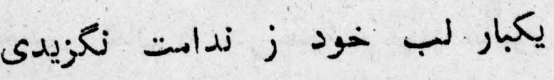

از زنك قماوت دل خود . را نزدودى.

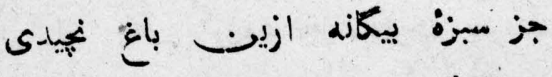

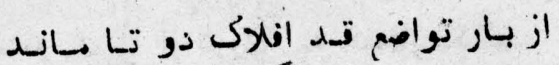

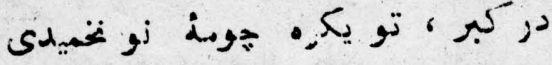

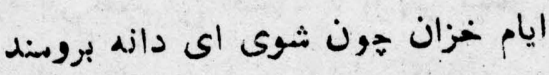

از خاك جو در فضل بهأران ندميدى ؟

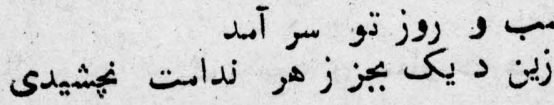

از ثوق ثكر مـير بر آورد برويال

صائب تو درين عالم خاكى جه خريدي
سلسلة: اعصاب جبهه جهاد را به م.سائل اغفال كنيدة

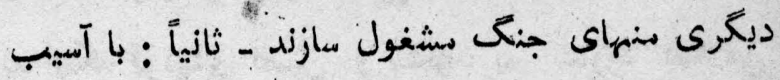

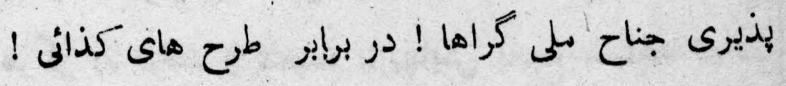

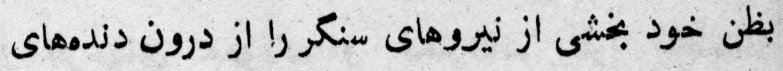

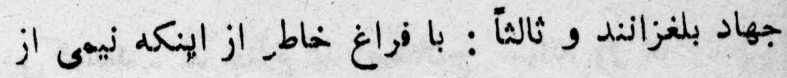

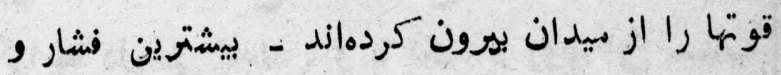

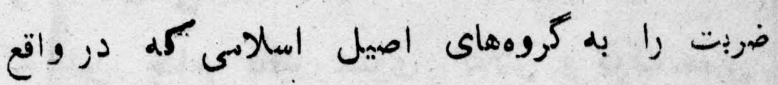

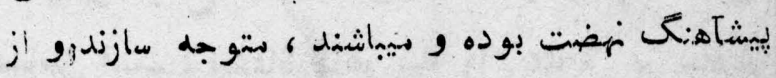

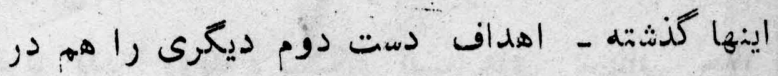
هيشت سر اين خطوط اصلى يدك إكشند.

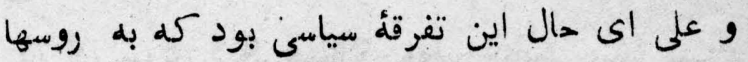

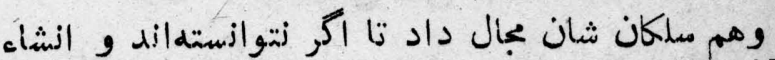

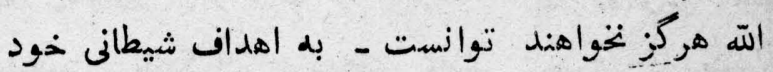
ازين كور انديشى هادست يابند - حداقل به آيندة كه به يقين جز شكست دينى ديكرى براى شان نخواهد

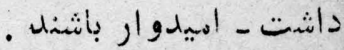
Y

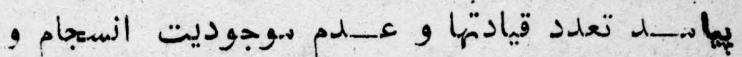

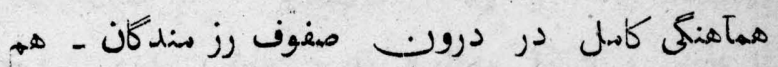

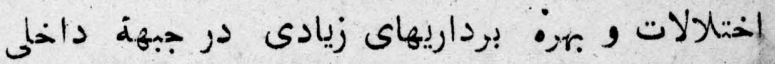
انقلاب بود كه دشهنان اين مبارزه بااغتنام فرصت

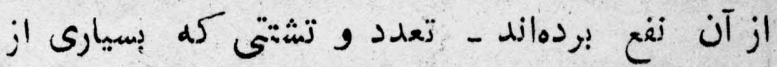

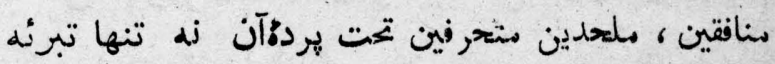

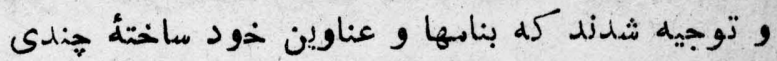

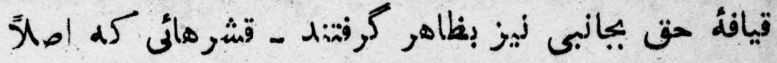

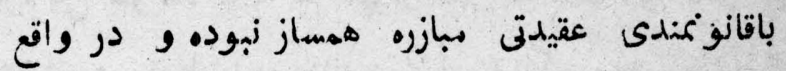
جهت مبارزه را كه حركت بسوى امهلاسى شدن جامعه

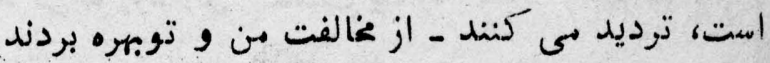
و منظور تنيدلن تارهاى توطئه و ضديت بامشى

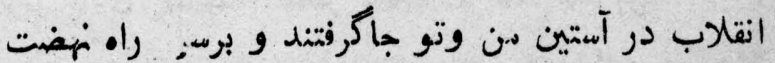
نئك ازيد اختند 


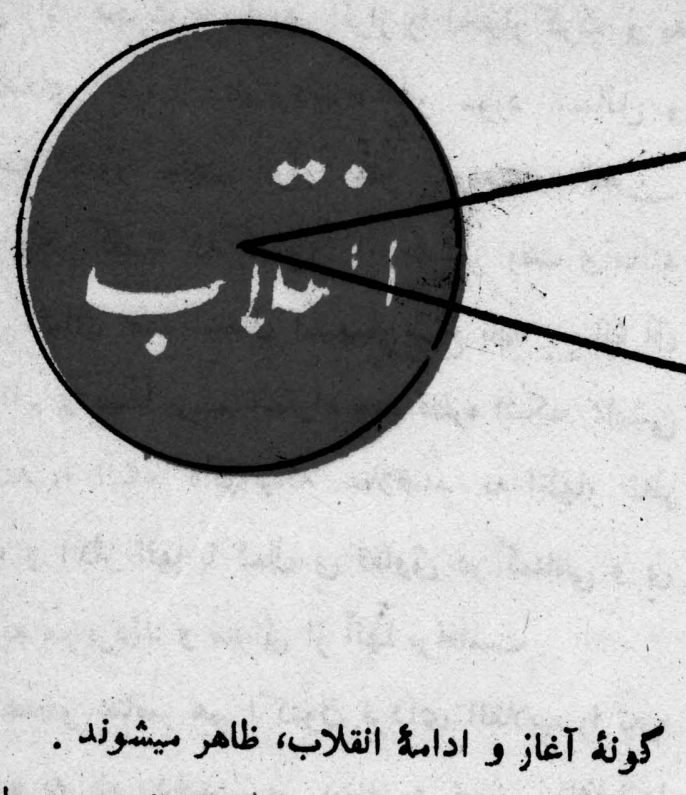

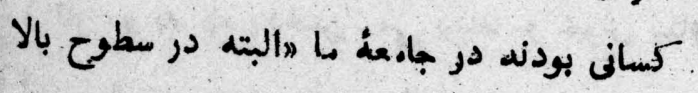

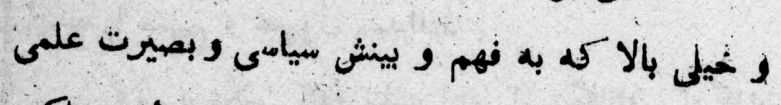

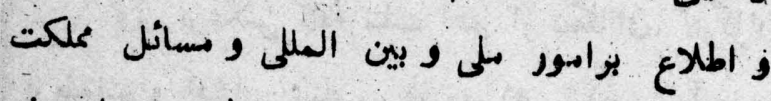

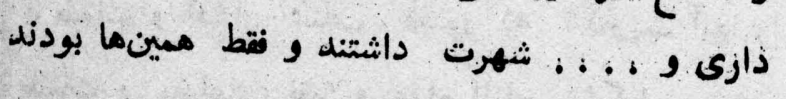

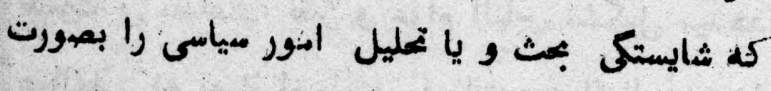

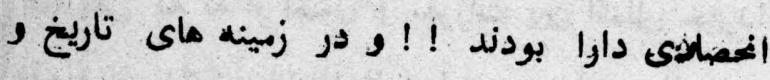

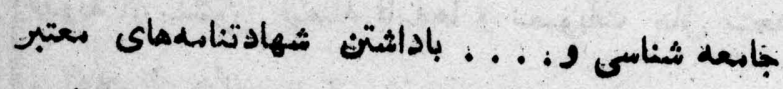

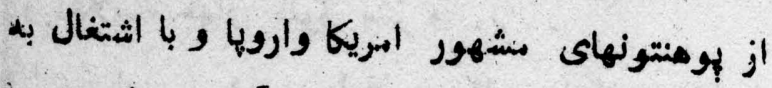

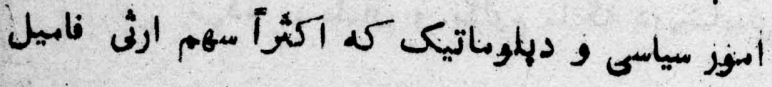

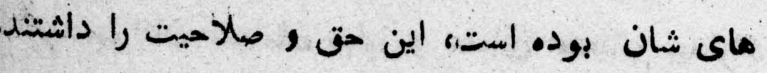

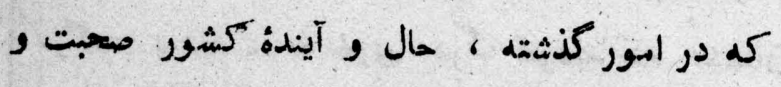

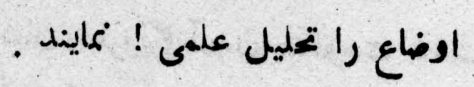

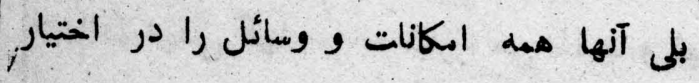

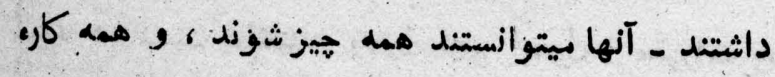

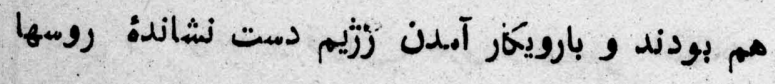

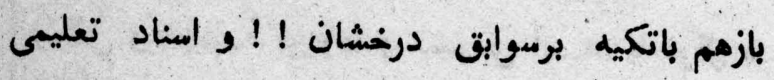

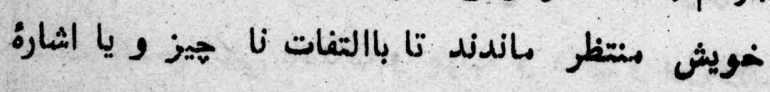

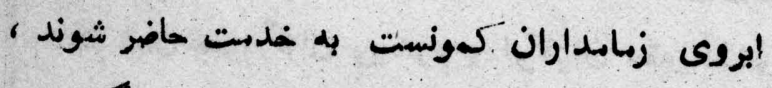

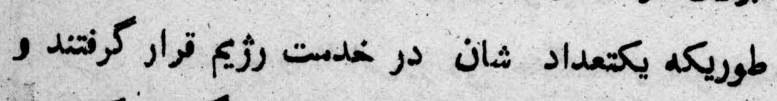

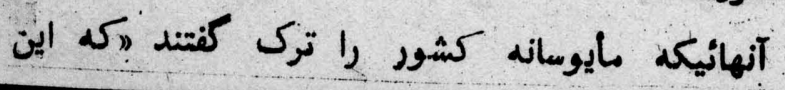

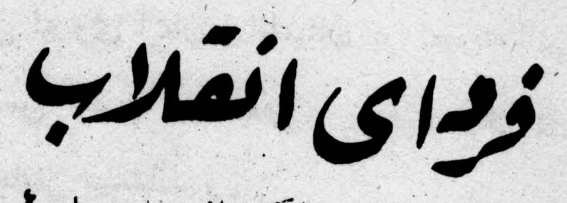

شريف اله ثتيرى

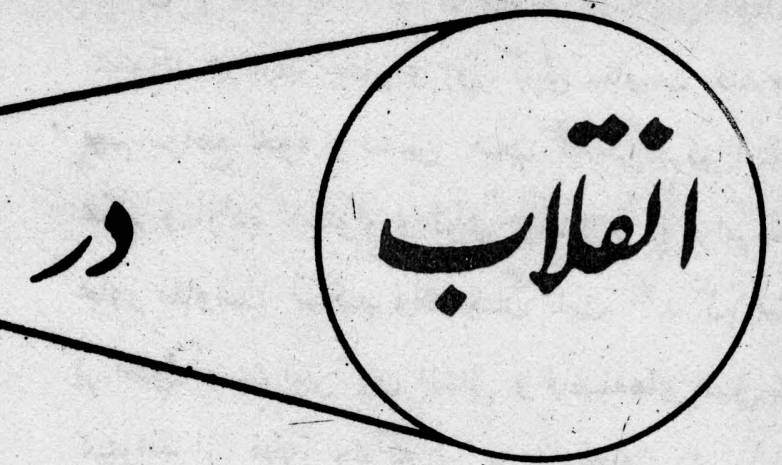

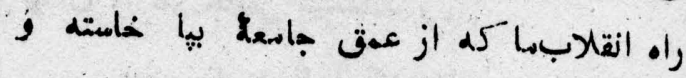

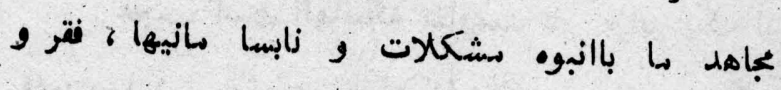
تنكمدنى ؛ عدم م-وجوديت هركونه امكانات و وسائل

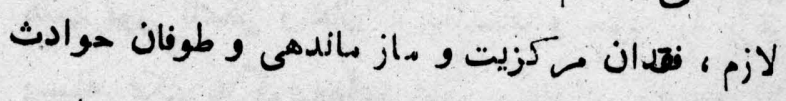

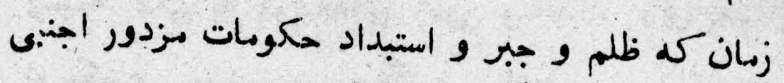

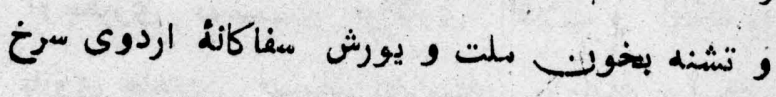

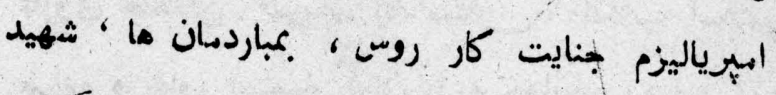

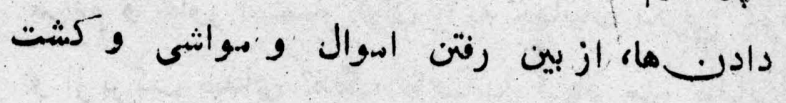

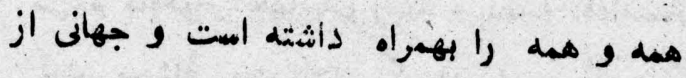

$$
\text { وزرع و }
$$

هطرات و رويدادهاى درد آلودى را بذيرا شهده و هر زوع زممت و سختى را لمس نموده و با تمامى فنشارها

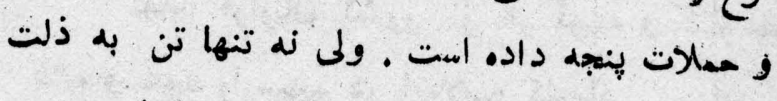

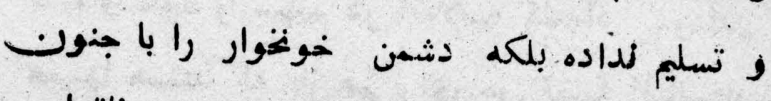

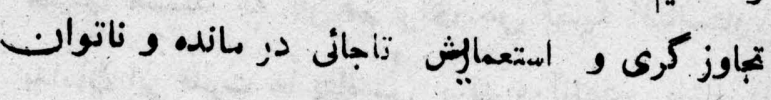
. مانته است كله به عقب نشينى و تسليم بناه ميبرد .

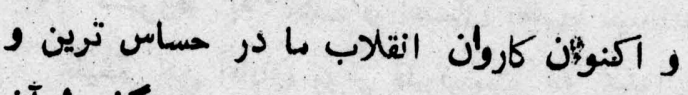

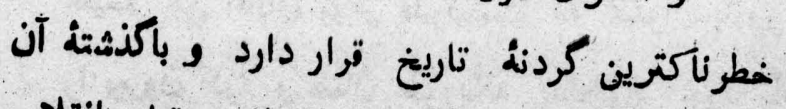

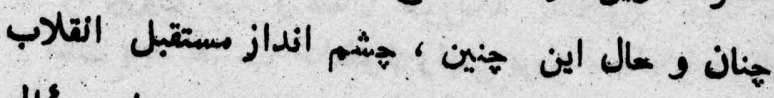

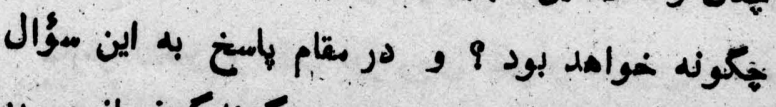
يكبار ديكر طروز ديدهاي متفاوت وكونا كون باز مم به وله 
بلى انقلاب ثابت ساخت كه فهم مسائل خشكى

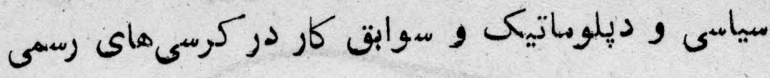

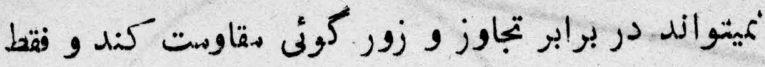

فهم بواضغ خود و دشمن البت كله در بيرتو ايمال.

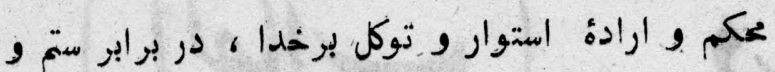

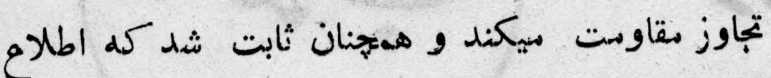
بر اصول و سوازين يين المللى و فيصلههاى ملل متخد

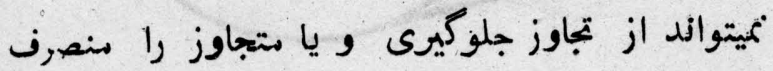

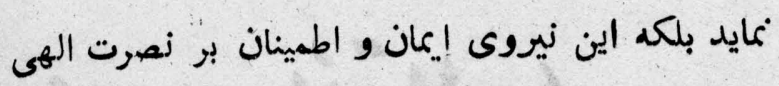
و شكست دشمن است كم تجاوز را برروى تجاوز زده. وآن رائ سر مينشاند و. ....

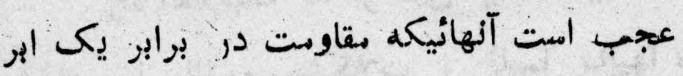
قدرت را ذز روزهاى اول كودئانى خوتين و ننكين

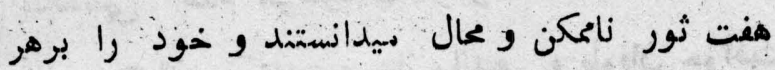

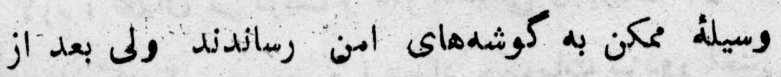

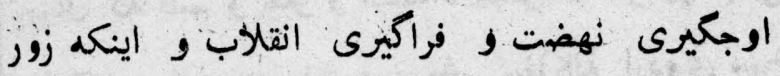

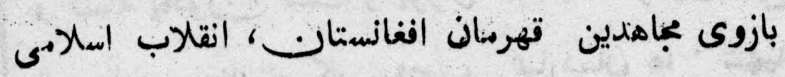

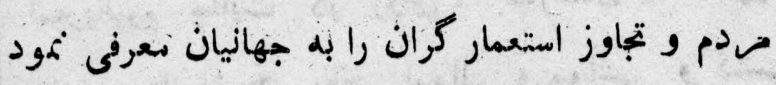
و از بركت صداى تفنك مجاهـدين فرياد حت طلبانـن

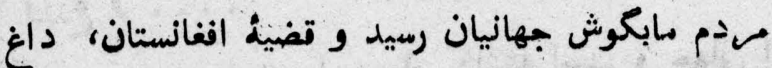

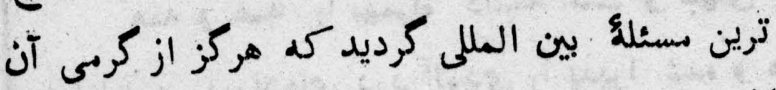

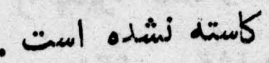

لهذا فراريان كشور از هر كوشه و كنار جمع

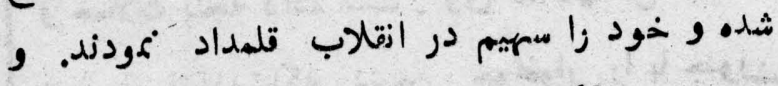

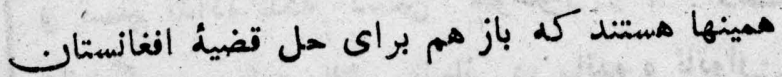

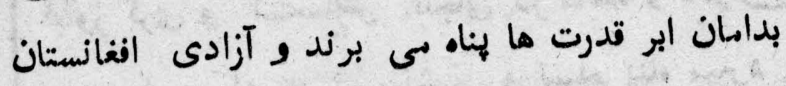

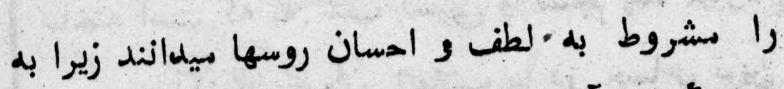

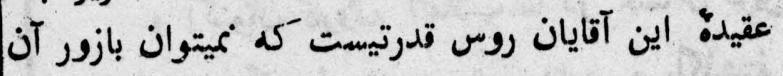

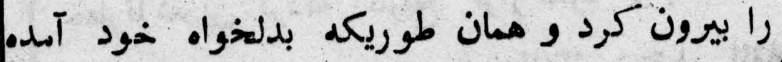

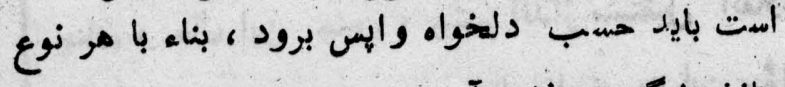

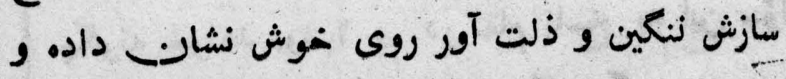
آن را يكانه راه نجات ميدانند و . . . ولى ما اميدوار.
خود الكانات و واسطه بيخواهدها و بياى در بيش

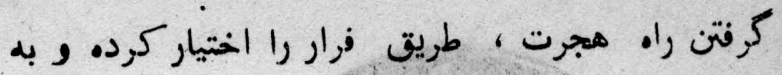

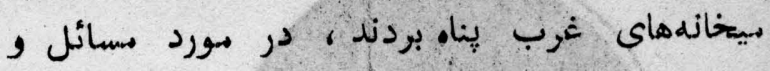
حوادث كشور ينين ابراز نظر نموده و و بالحي.

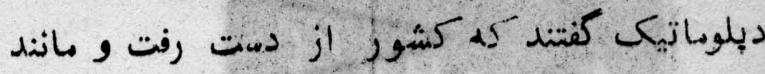
مناطق شمالى تهت اشغال استعلىار سرخ بايد جنازة آن

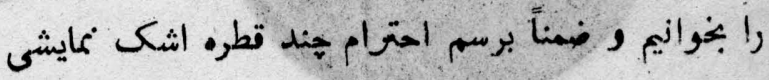

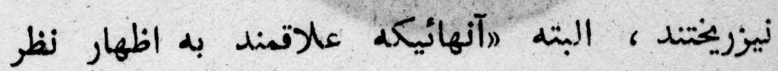
بودنده و أكثر آنها بإكمال بى تفاوتى در كمنامى و به: وطنى به سر بردند و صدانى از آنهل برنياست . همتجو عناصر هم اكنون فرداى انقلاب را تيره

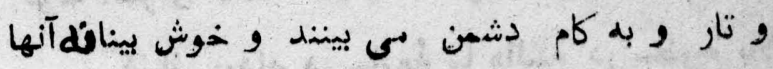
آينده را نبهم و مجهول ميدافند . ولى برعكس كانة ملت اعم از دهعانان، كاركران

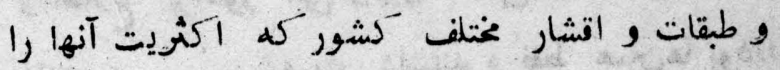
طبقات هى بضاءت، فقير و عوام الناس تشكيل ميدهد،

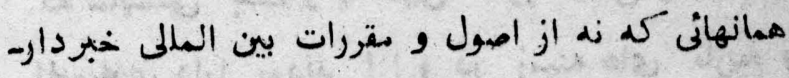

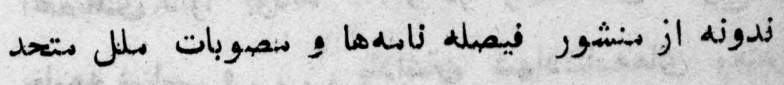

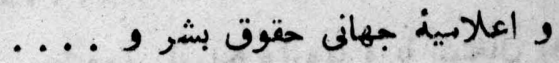

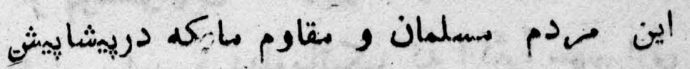
آنها جوازان مسلمان مبارز و علماى مجاهد و بيدار در

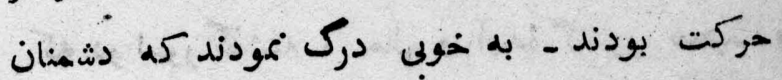

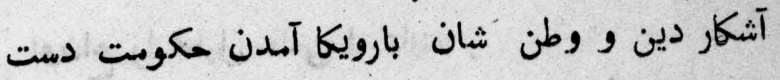

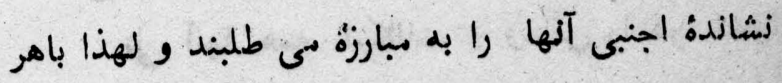

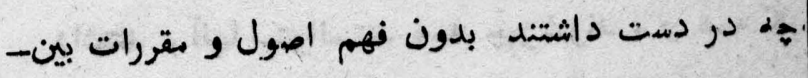

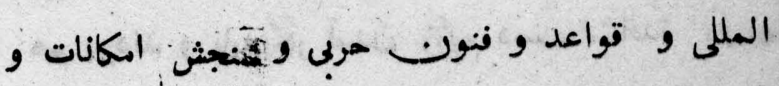

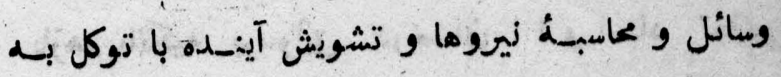
ذات اقدس الهى باسنك و هوب و داس و و بيل وتبرو

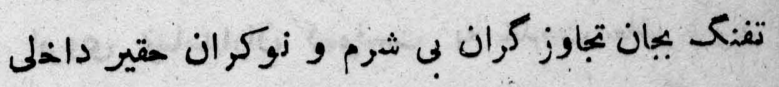

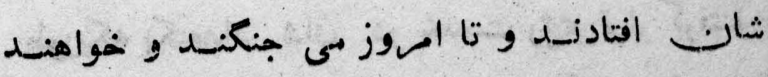
جنكيد 


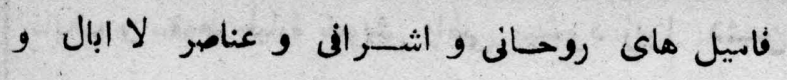

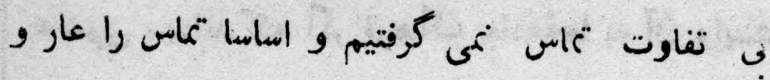

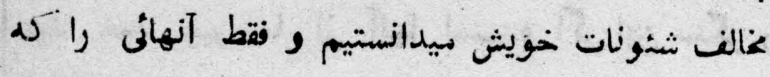

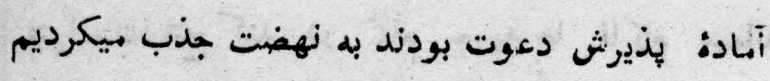

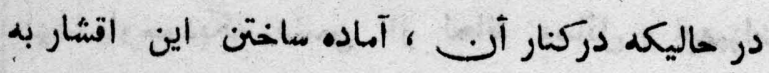

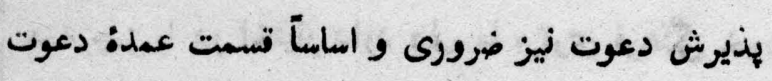
را تشكيل مى دهد ولى با اين اعتياط كن تأثير كذار

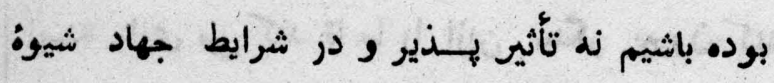

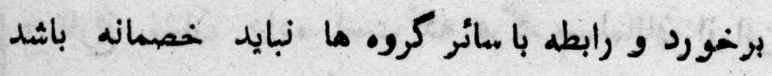

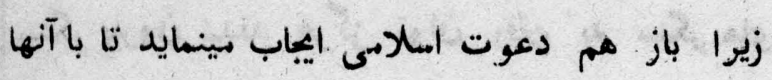

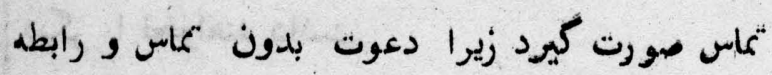
امكان بذير نيست و اينكه با بكاه هاى ترش و كينه

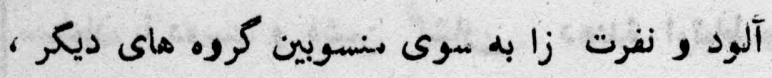

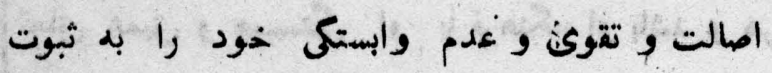

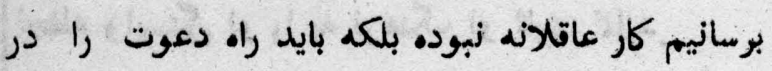

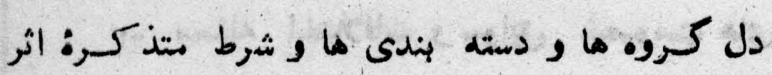
كذارى دنبال نمائيم.

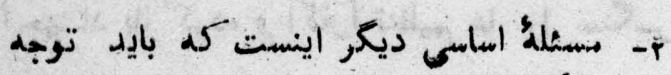

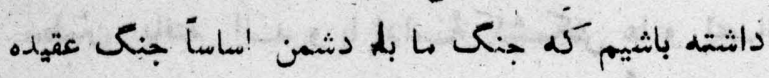

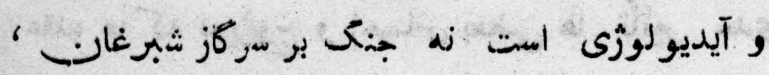

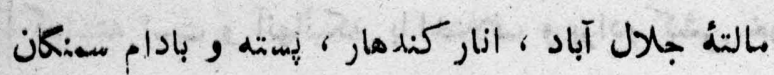

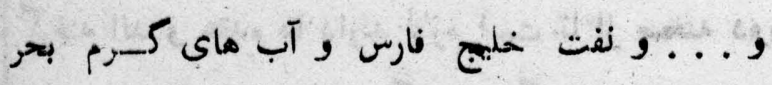

$$
\text { هند و.... }
$$

و اين سوضوع كه جنك لما جنك عقيده است

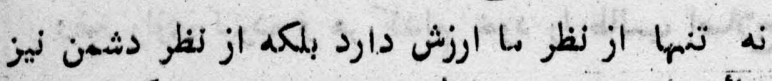

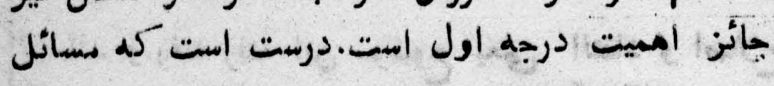

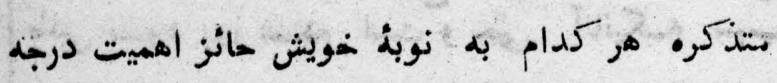

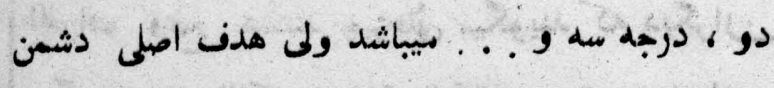

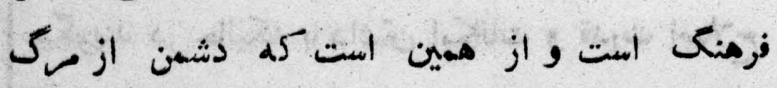

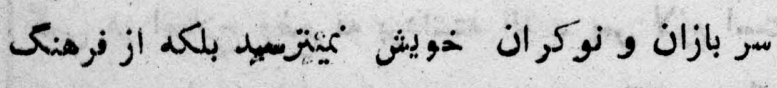

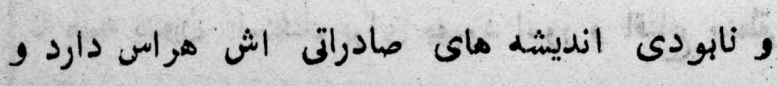
بخاطر زنده نكه داشتن آن به ركى سر بازان و تحريب

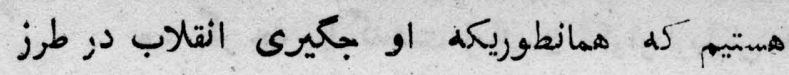
فكر و قضاوت و برداشت اين آتايان از مسائل كشئور

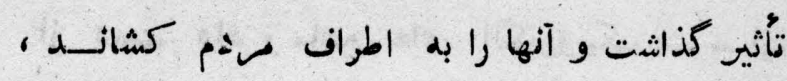
جريان و ادائ انقلاب اين فكر يويج و تسليم طلبانه رانه

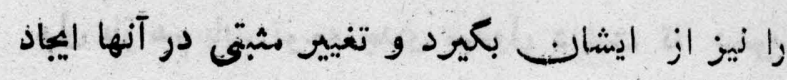
نمايد.

نى جهت نيست كد در اين زمينه تغيير ديكرى

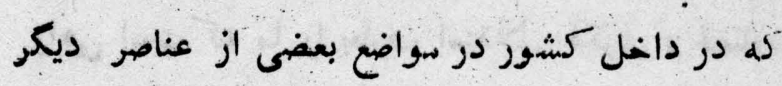

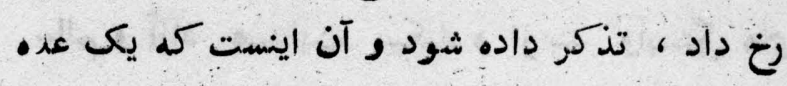

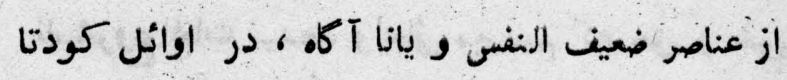
تحت تاثيو تبليغات ثعبده بازى ها و رقصندكى هاى

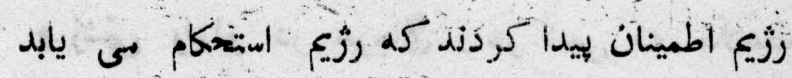

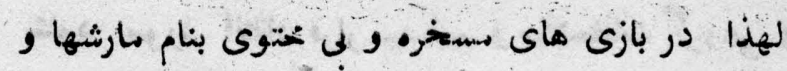

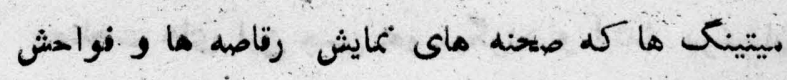
بود ، شركت نموده و حتى بخدمت سربازى رزئي نيز

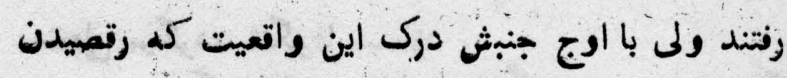

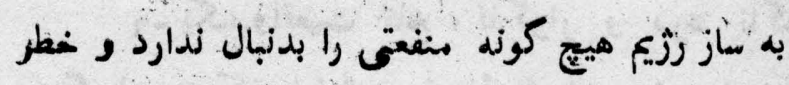

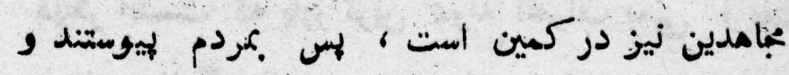

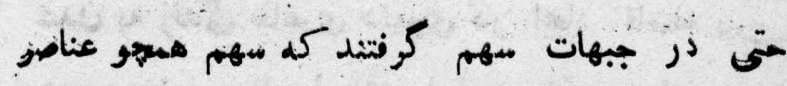

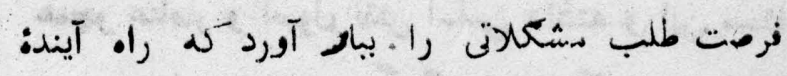
انقلاب ايجاب تصفية آن زراب مينمايد.

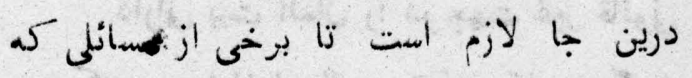

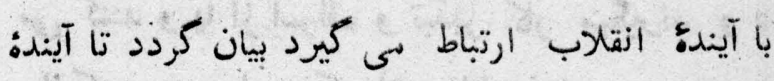

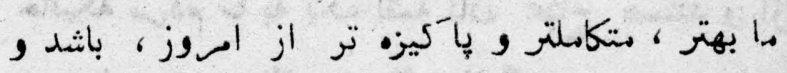

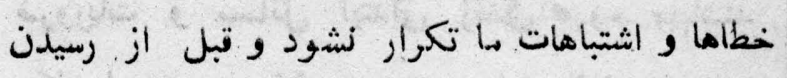
به بيروزى كلمل در تصحيح آن بكوشيه.

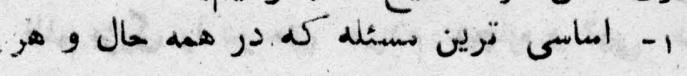

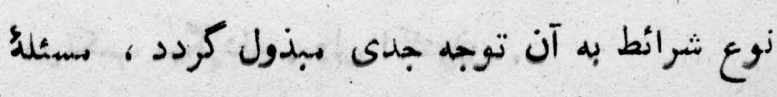

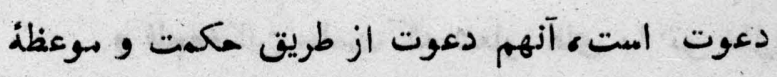

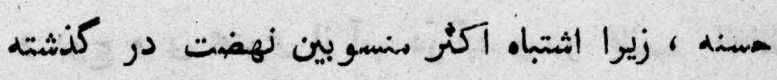

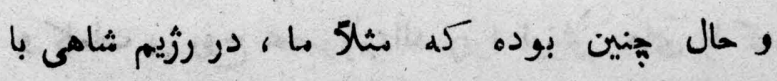
طاحبمنصبالب - عسكرى ، مأمورين عاليرتبd دوتتى ، 
ه. كر جه با كذشت زمان و تكرار آزمايش ها تا مدود زيادى كيش شخصيت كرمى بازار خود را از دمت داد و ماثين هاى الكترونيكى بت سـازى با ترار كرفتن سنك ما در لائ هرخ آنها از كار افتادند وله باز مم باين توجه جدى مبذول داشت تا دعوت بر روى طرز فكر و مدف نهضت صورت بكيرد نه تمت عنوارن شعضصيت رمبران. و اين طبيعى ترين رامى است كله ما را بطرف استقلال فكرى و تضاوت

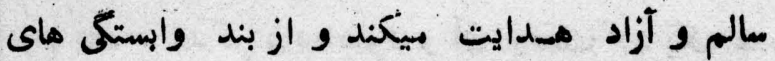
نامشروع نجات ميدهد و بيائى ميرسيم كله مت و خوبي را در مرجائى و هر كسى كه ديده شود تأييد و باطل

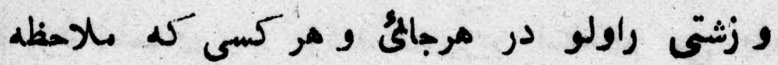

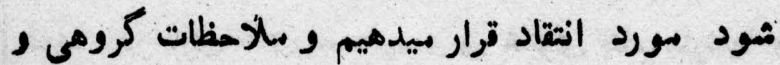
مصلهت ماى ابن هنين محو ميكردد و آيندة درخشان خاللى از تعصب را كله ومهد اسلامى ما در آنـ

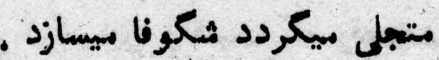

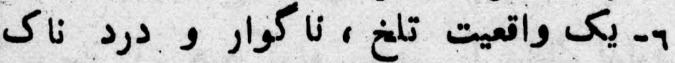

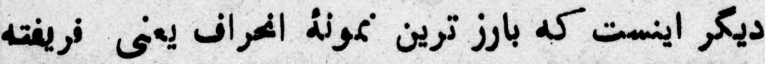

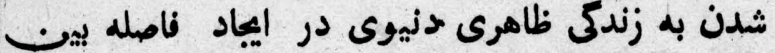
همرو عناصر و اصول نقش اساسى داشته و اين مسئله در همه با مورد بحث و كثتكو ترار ميكيرد . دارائى يت السال را در جهت غير قانونى مصرف

مى كنيد و يا از اسراف و تبذير كر ميكيرند و در

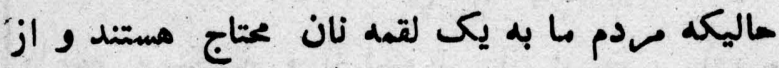
ضروريات و مسائل ابتدائى زندكى معروم ميباشند .

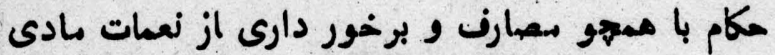

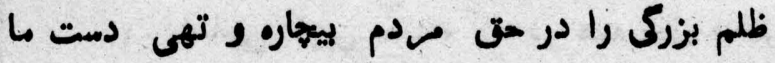
هتكب ميكردند . ولى اكنون. . . و كاجعه اين جاست كه شعار هاى ما تو خحالى

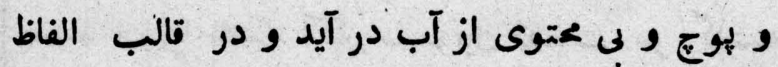

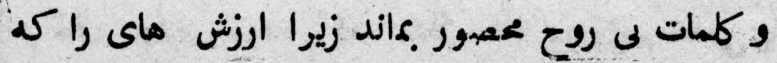
بهيه دو صفحكة كمي
تانك و سقوط طيارة خمويش راضى ميشود زيزا دشمن

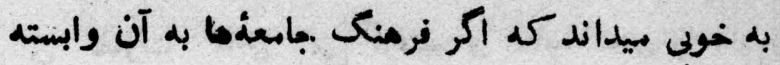

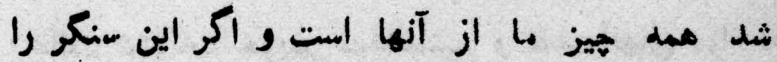
نتوانست نتع كند در تمام جبهه ما ناكام ميهاند لهذا باوجوديكد دشسن از لهاظ ومائل و تجهيزات مهل بيز را در اختيار دارد ولى ما برترى فرمنك خود را ثابت ساخته ايم و اكنون دثمن تلاش دارد و

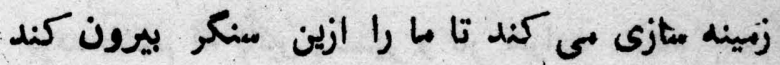

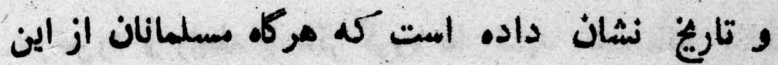

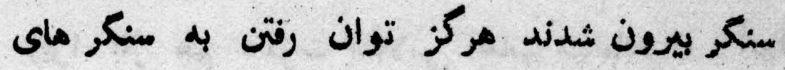
ديكر زا نخواهند داشت. لهــذا بايـد قول · عمل و ثهوهُ برخورد يكى

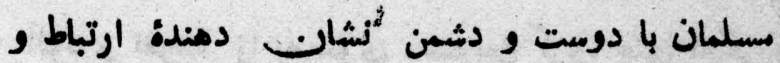
تعلق عميق و ممبستكى او با فرهنك او باشد و هر لحظه وابستكى او را به فرهنك او ثابت نمايد.

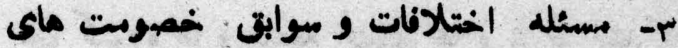

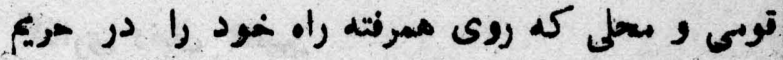

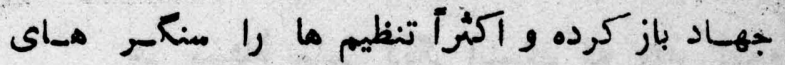

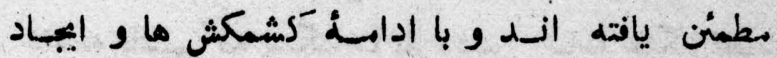

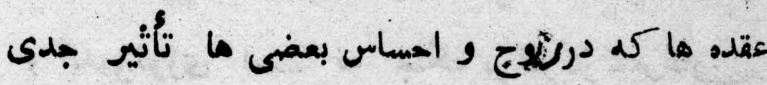

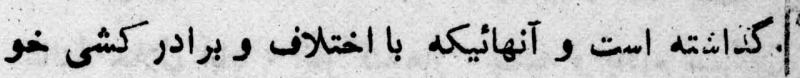

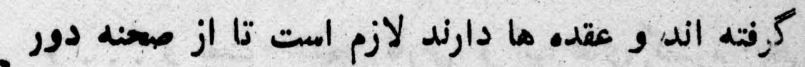
شوند تا از بروز حوادث ناكوار جلوكيىى شود.

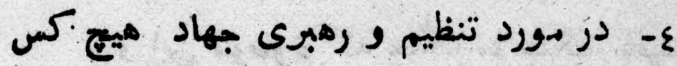
از وضع رازى نبوده و هر كدام خود را طالب اصلاح

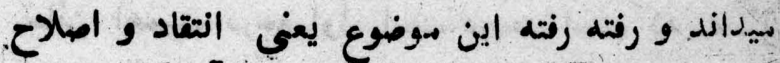

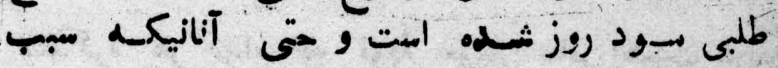

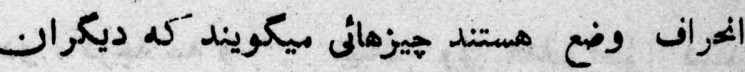

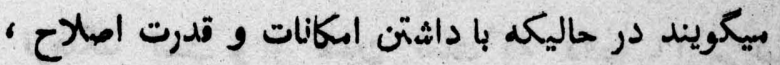

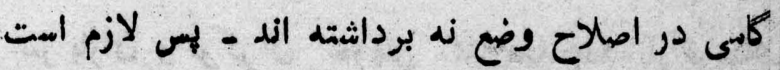

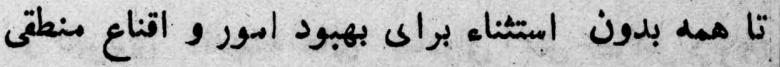
ديكران شورش نمايند. 


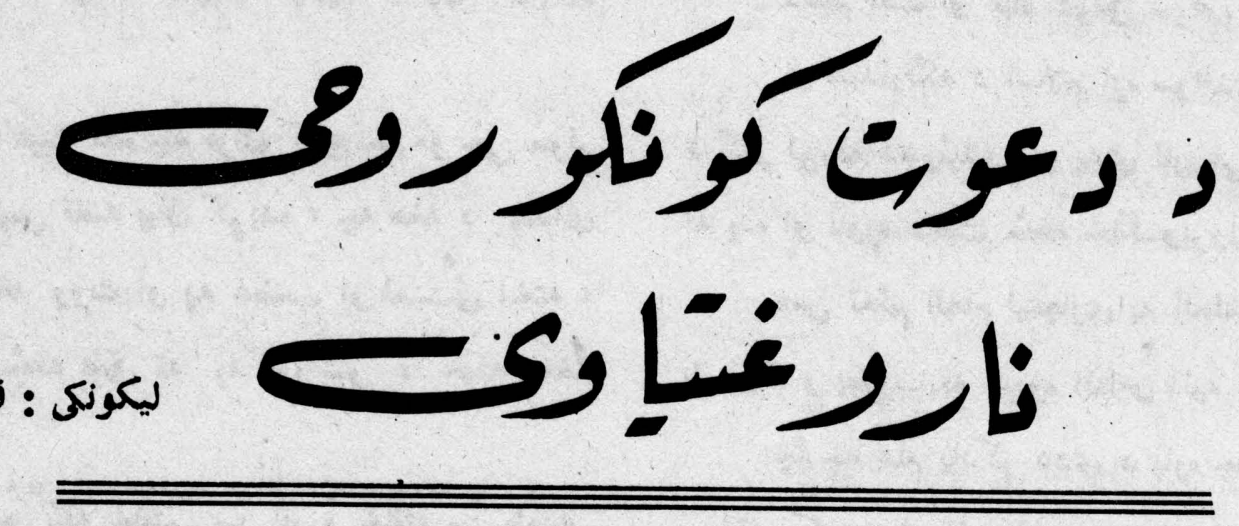

(r)

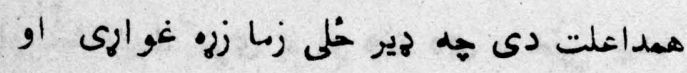
دا خرورت احساسوى حهـ دمغو مشكالاتو او ناروغيو

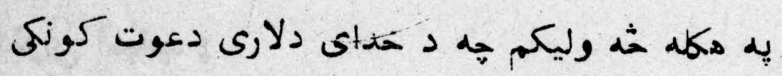

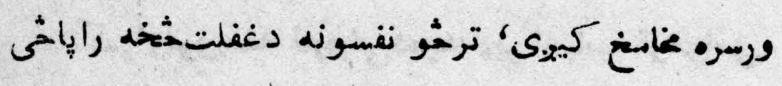

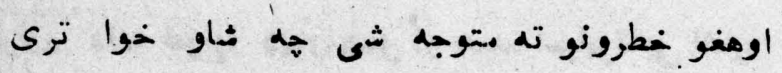

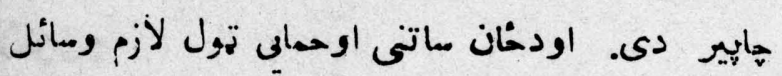

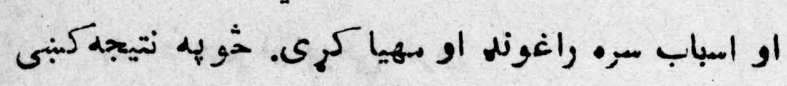

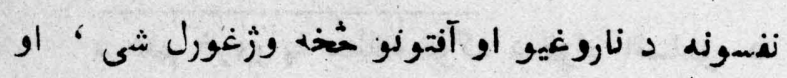

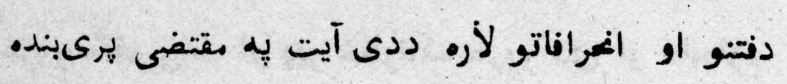

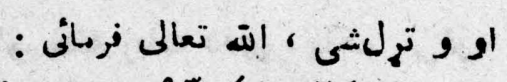

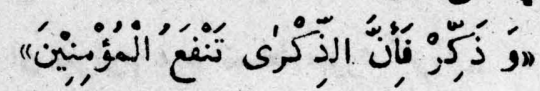

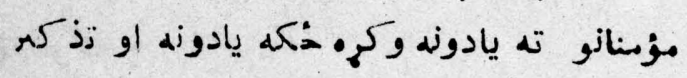

$$
\begin{aligned}
& \text { مؤمنانو ته كتهله رسوى. }
\end{aligned}
$$

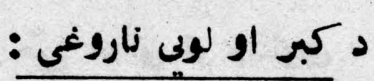

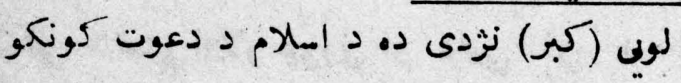

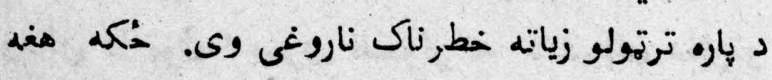

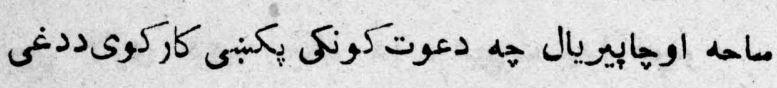
نلروغى دراييدا كيدو ودى او طغيان دياره هير مناسب إيب

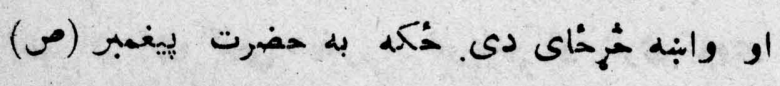

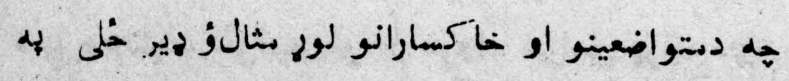

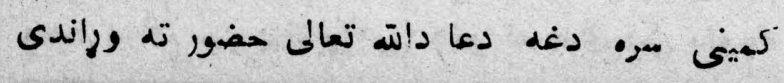

د املام دعوت كونكى د تولو فيخه زيات

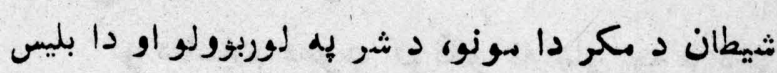
دغولوزو هيه معرض كسنى واقع دى . . . . :كله د نورو

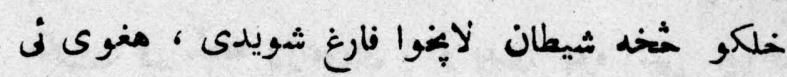
راليوخولى اواوسنى دخهل حزب او لبنكر يه حله كبنى ته

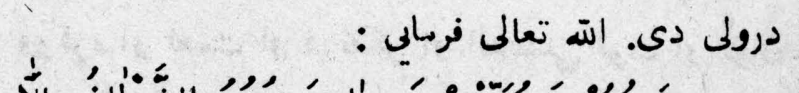

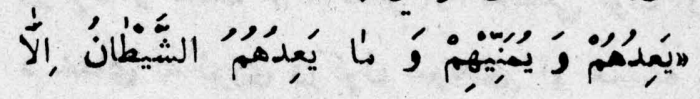
غُورن" ثبيطان دوى ته وعده وركوى اوهيله بندكوى ورى

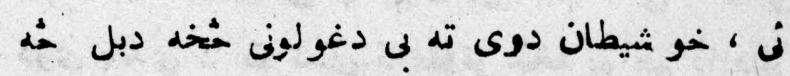
وعده نه وركوى. همدارنكم د امدلام دعوت كونكي دهنو عوامو

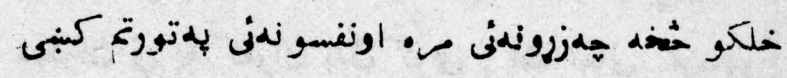

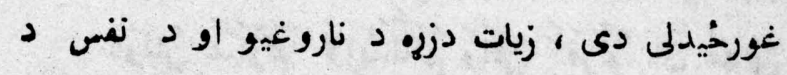

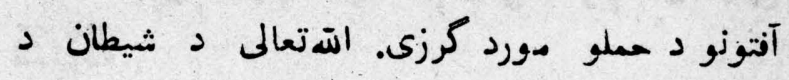

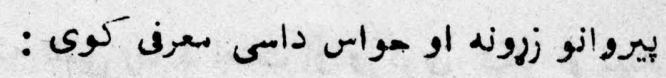

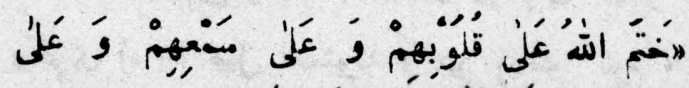

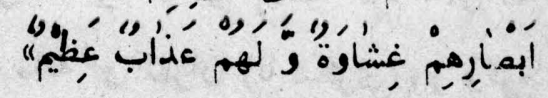

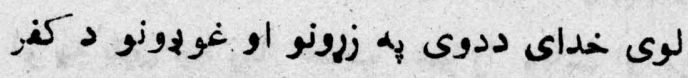

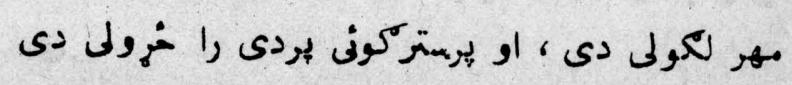
او ددوى د يار لوى عذاب دى. 
:

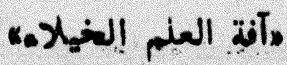

دعلم آنت او تباه كونك مض كبر اولون ده.

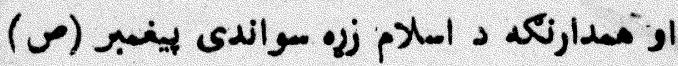

د كبر لمورته دبخويدو او هدى ناروغى داخته كيدو له بده او ناوره عاتبت شيخه خلكويرولهاو فرمايلىدى:

"امن تعلم العلم ليتبارى به العلعاه و يسارى به

السفله و يضهرب به وجوه الذاس اليه ادخله الشالناره

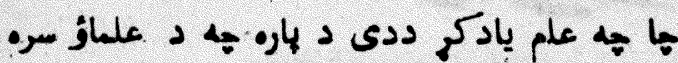

مسابته وكىى، او نايوهان لرى و غولوى، او دخلكو. منونه د خان لورته هرى راواروى ، اله تعالى به بـ

د دوزخ اورته ننه بإسى.

نو د اسلام دعوت كو نكو ته بناق .جه د دغى

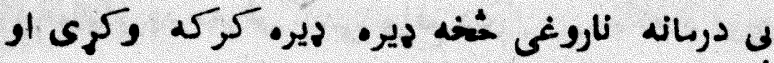

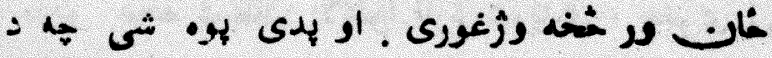

غطانى دغه ملكه او المتعداد ، او د ليكنى دغه

درك, او نعمت او د تنكر او انديبنى توت او توان

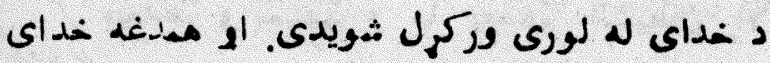

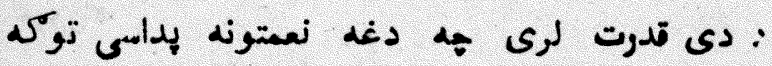

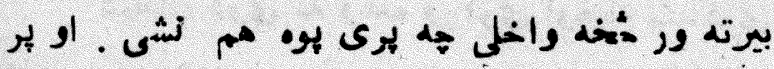

دوى باندى د اله تعالى د مقوقو ئخه يو هم دا دى يرى

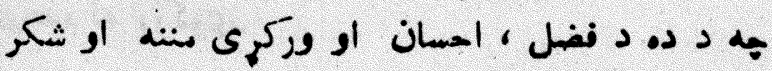

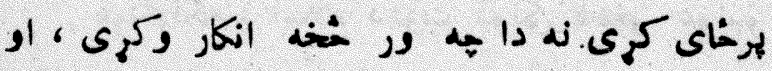

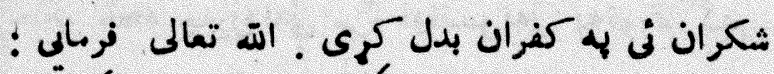

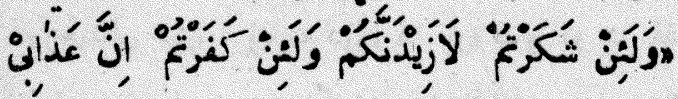

- "

كه تاسى زما د نعشت او وركمى ثكر او منته

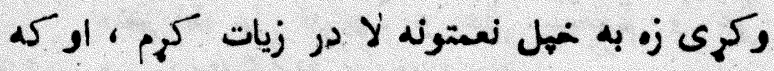
رما نعهت موونه ماند او كنران (نا شكرى) مو وكره

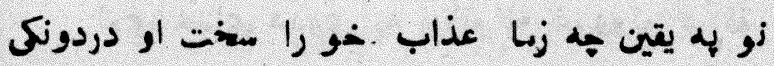

E(Ar)dï

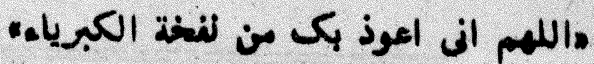

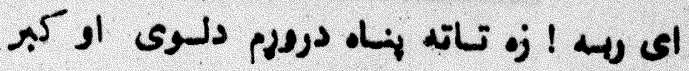

.490243

او دا عبث لله به قرآن كريم خوشئ شلى موني

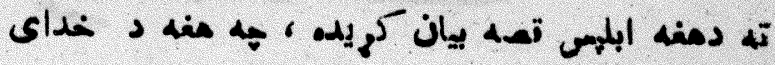

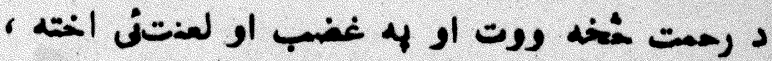

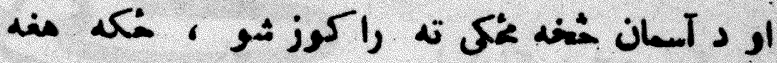

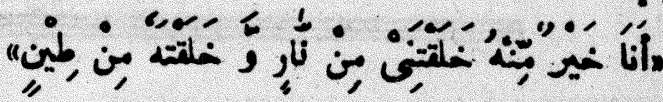

: is

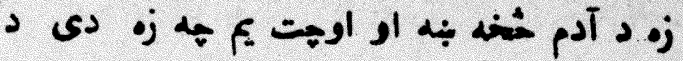

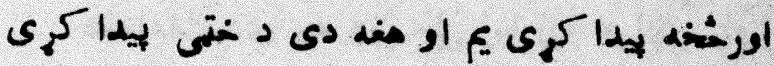
دى.

:

كيراولوبهغ ناروغيدهبه دير اهباب اوعواهل لرى. دلةه غوارو هيرومهمو او عمده امباوتلدي الماره $: 92$ ו-

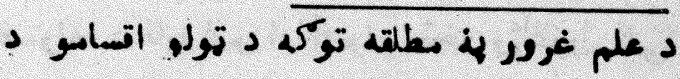
غرور خيته زيات او دير خطرناك غرور دى او داسلام دعوت كونى د تولو فينه زيات ددى مهلك صفى د مكروب او جرثوم ، د تسلط مبود كرزى. د مثال : 4

ثهاد تنامى(برى ليكوته) معلىدرحىاورتى اود

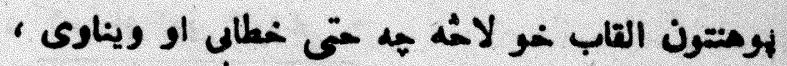

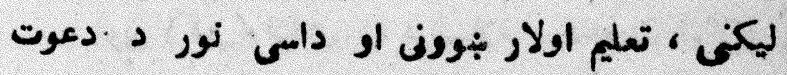

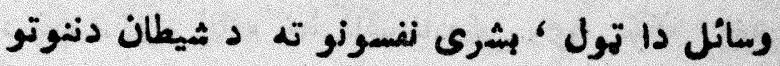

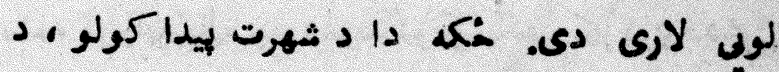
غالكو د نتل درا هلبولوك او د غرور درابارولو اسباب دى. او بلى كينى دنغ د غوبتتو او بشرى لوئى

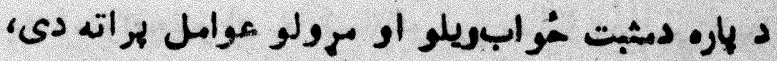

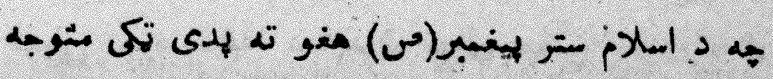


"نوشته سيد علام الدين " اثير "
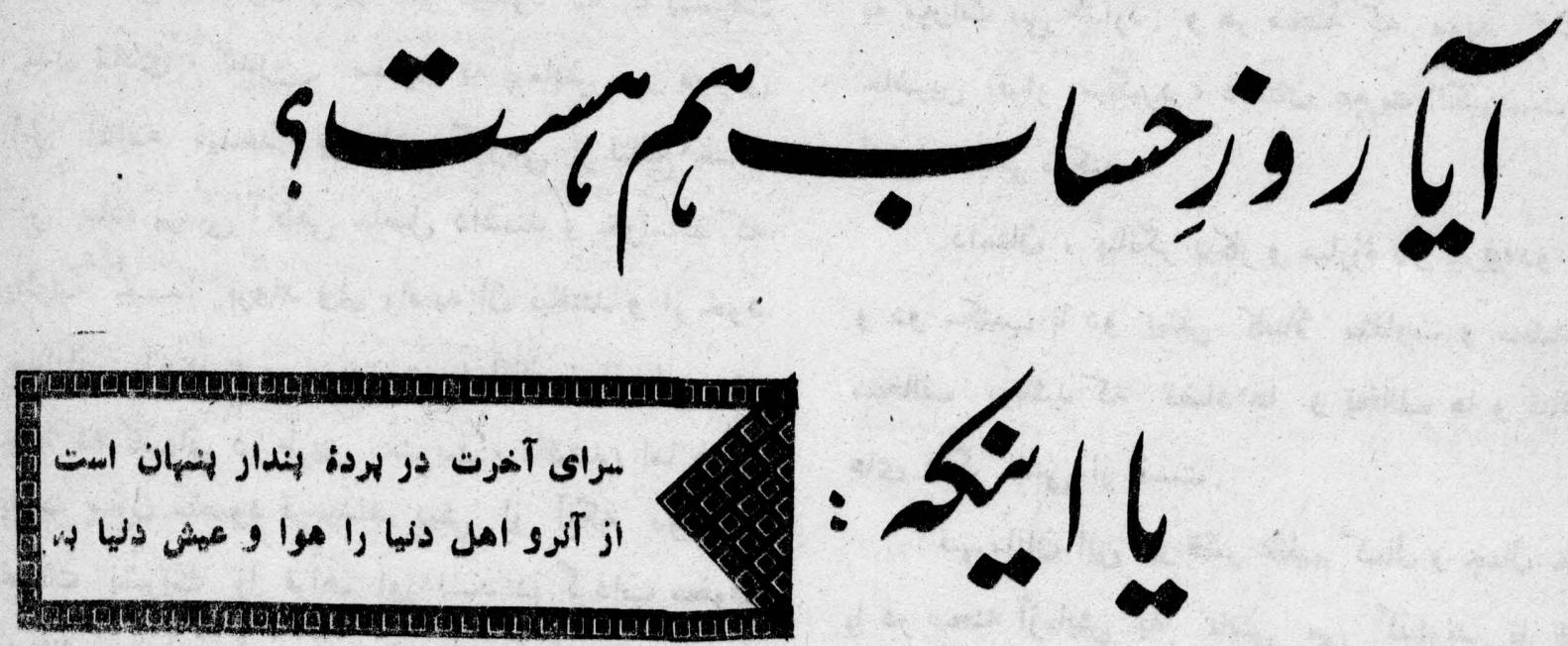

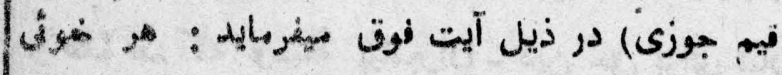

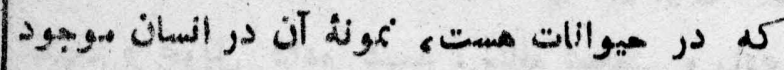

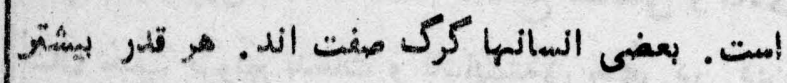

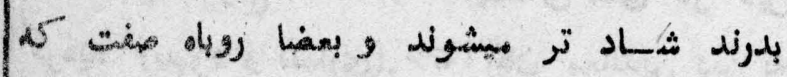

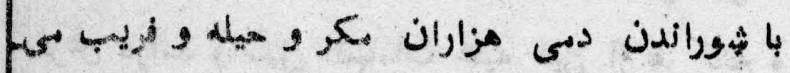

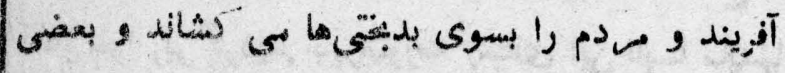

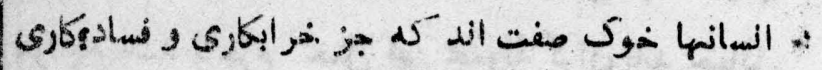

$$
\text { ندارند و على هذا القياس. }
$$

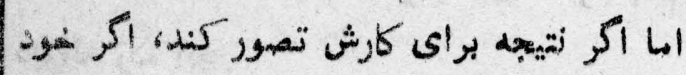

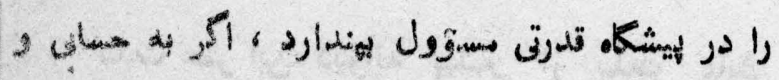

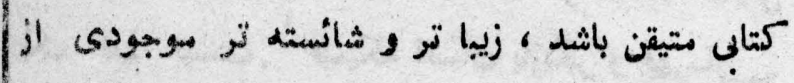

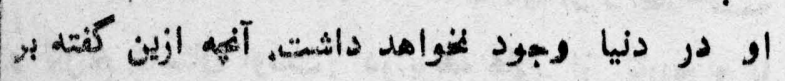

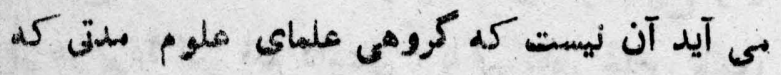

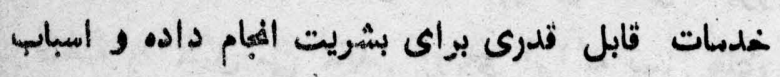

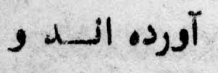
معيشت مم نوع خود را فراهم مادام العدر تكليف ور زهمت كشيده اند انسان نيستيند.

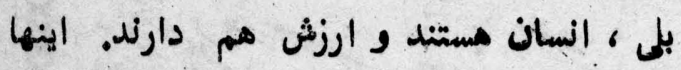
بغد ماكى بشرات را يارى كردند ، الها نتوانستيد

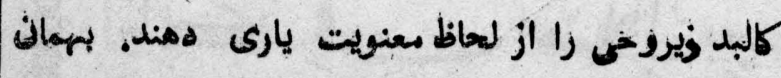

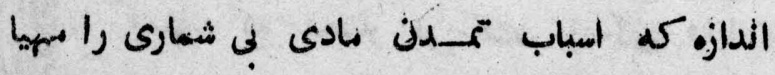
كرده اند از آنت بيشيتر انلاق و معنويت بشر

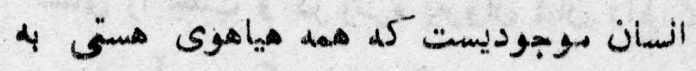
نهوى از الهاء به او مستبط ميكردد وتأثير نى كذارده،

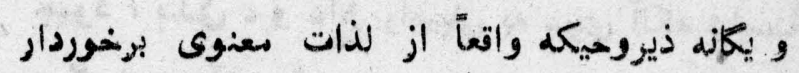

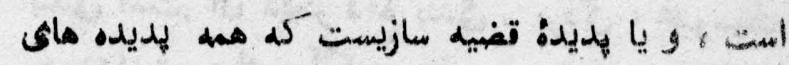
طبيعت صغرى و كبرى آن بوده و بايد روز رستاخيز نتيجه محتو م و قطعى اش باشيد.

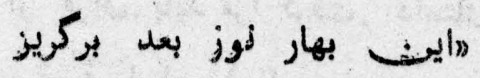

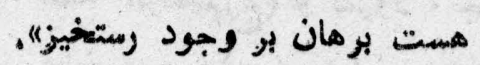

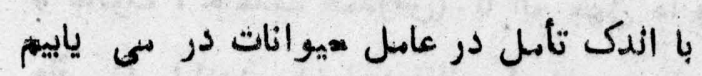

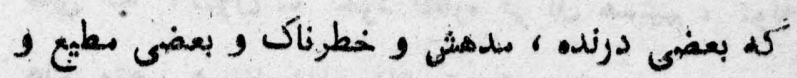

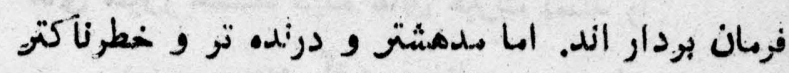

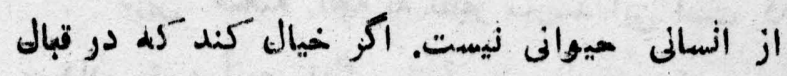

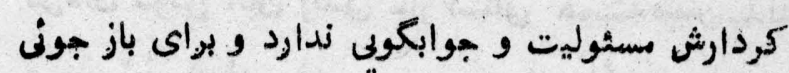
هركز فرا خوانده نيخو اهد شد:

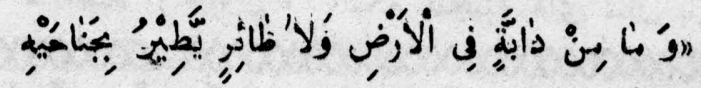
( $r \wedge / p)$

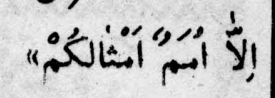

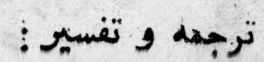

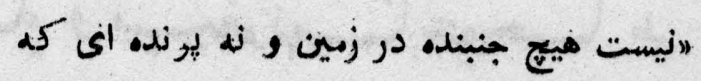

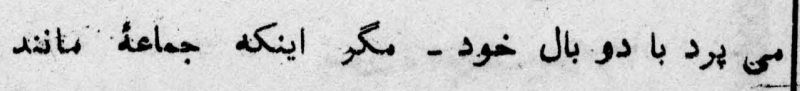

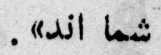
حضرت سفيان بن عيينه در (الجواب الكنف بن 


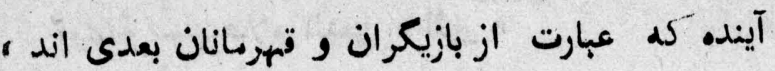

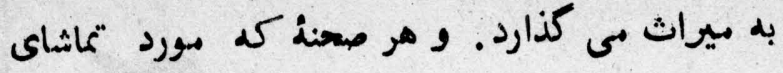

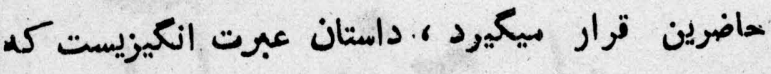
آنانرا متفكر, ميكند.

داستان ، بيانكر بيكار و مبارزة دو نيروعدو فكر

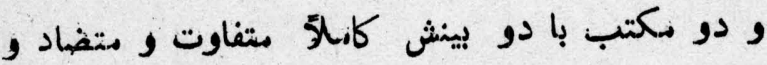

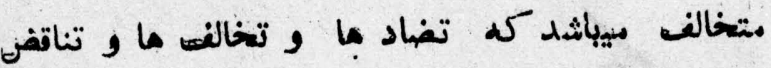

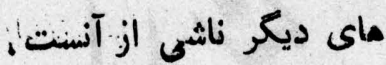
قهومانان اين دو تثثر عظيم كمال و جمال خوره

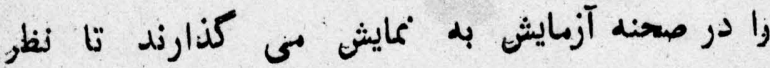
كسانى را جلب و در زمرة بيروان شان دالع 'مايند.

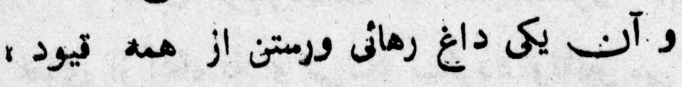

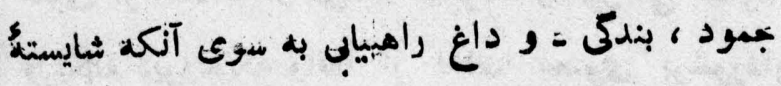

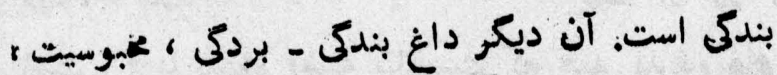

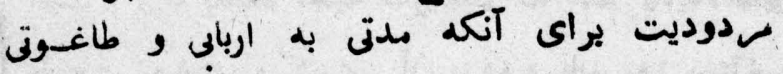

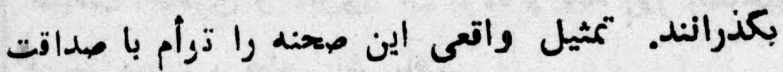

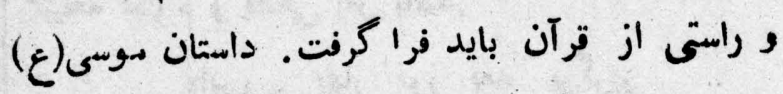

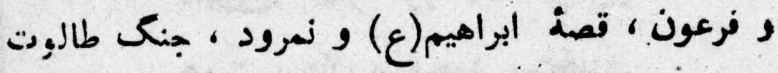

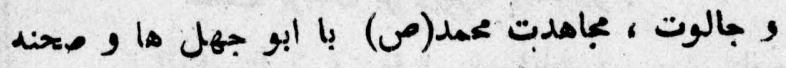

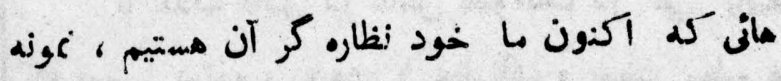
ماى متبرز مستند ديده هاى عبرت إيسند را.

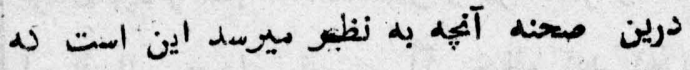

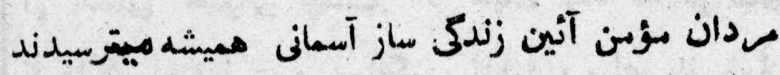

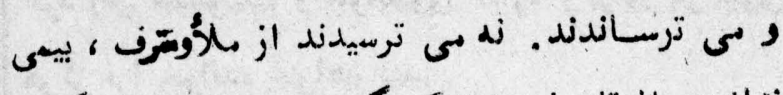

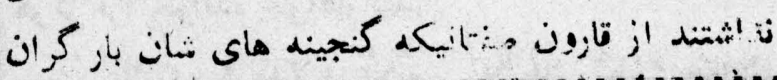

لِيف ساخته اند :

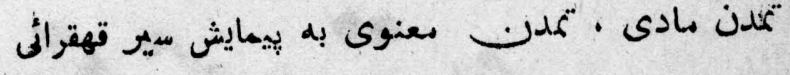

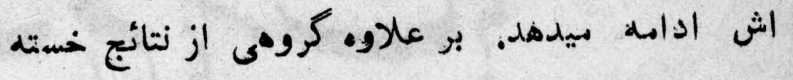

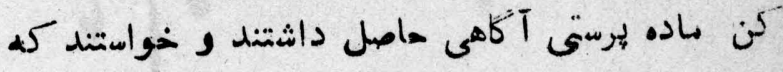

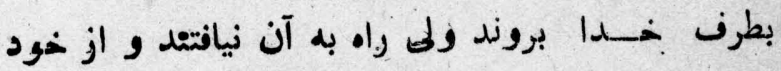

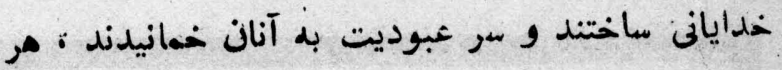
هند كه كامهائه در طريق معنو يت بوداشتند، امبا هركز

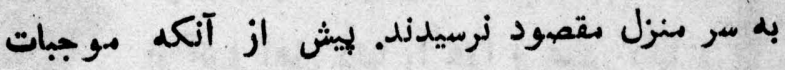

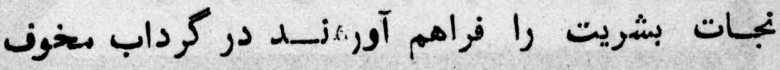

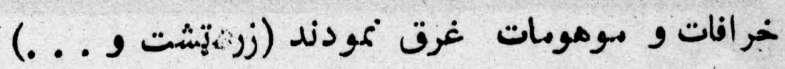

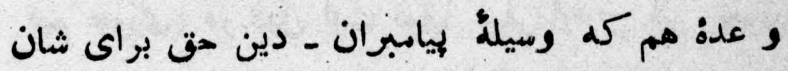

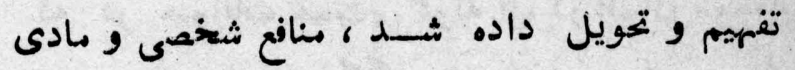

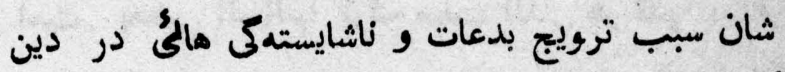

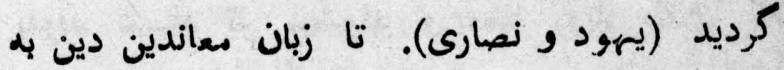

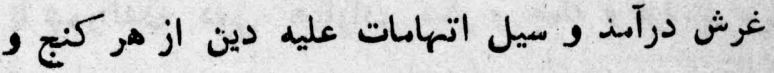
كنار سر' زير گرديد. بهرصورت بمبناى اين نابها ماينها

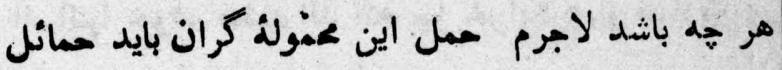

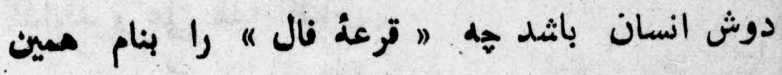
ديواند زده. اذد.

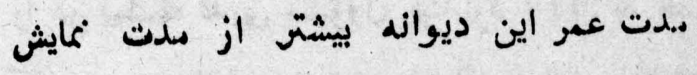

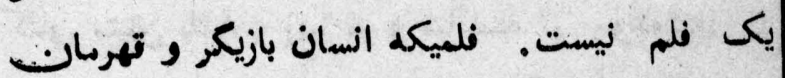

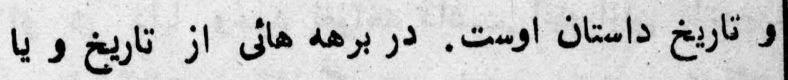

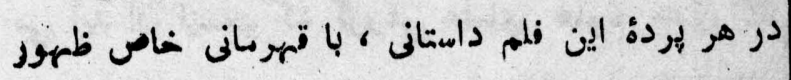

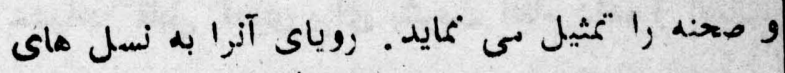

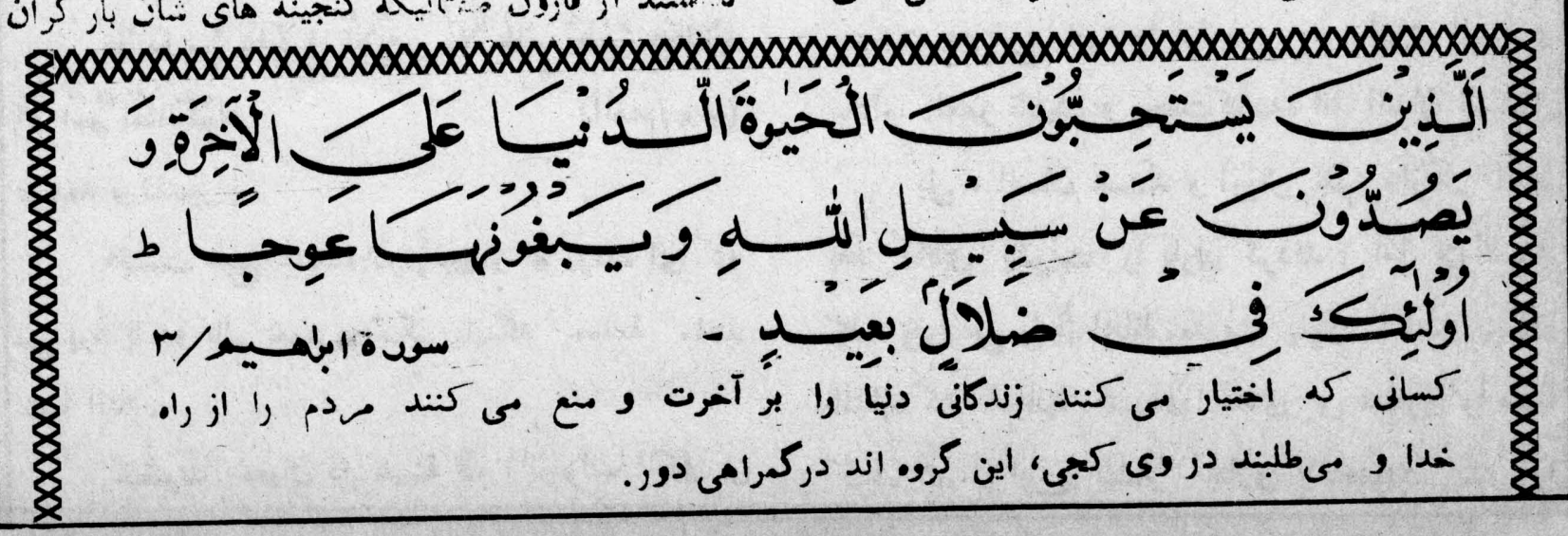


دز مورد آنهله كله در دسترس مان هست و مورد

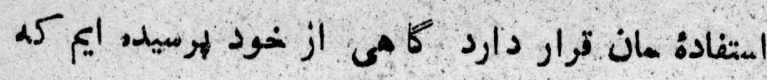

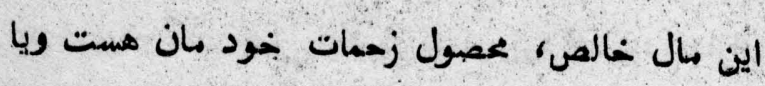

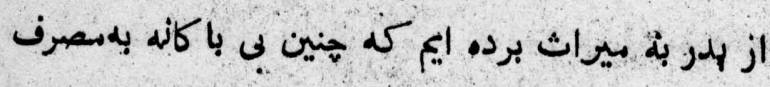
مى

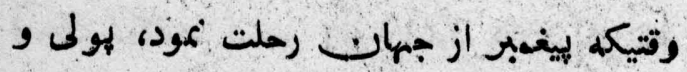

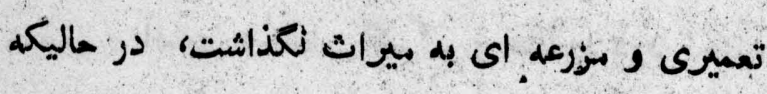

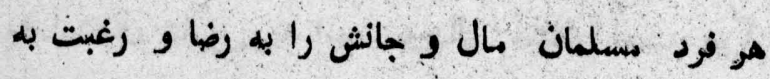

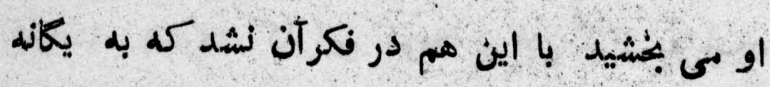

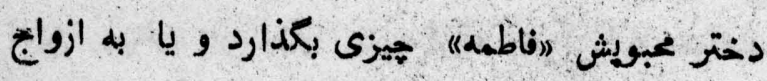

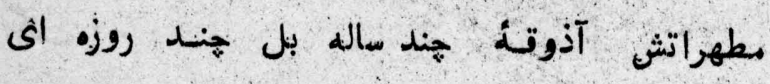
ذخير كند الند

افنسوبس , حسبوت بعال أنانيكه در فكر بيروزىى انقلاب اسلاسى نيستندو به آن به نظر شَّ و ترديد

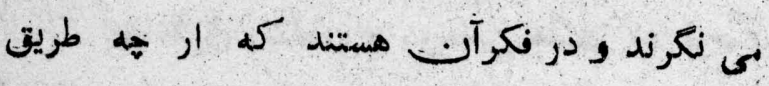

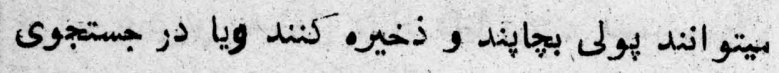

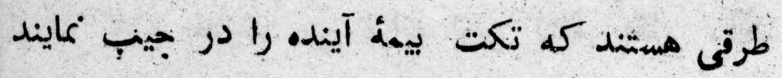

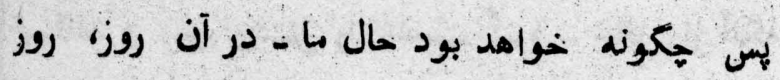

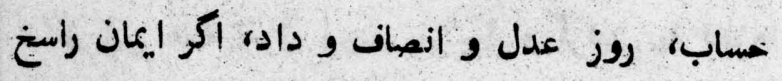

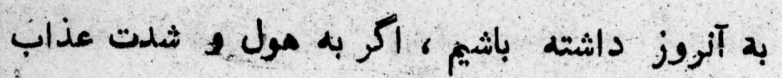

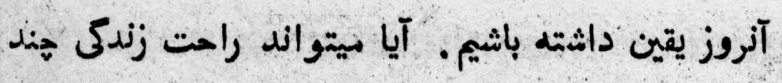

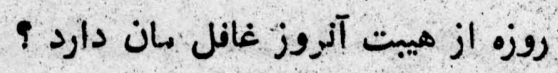

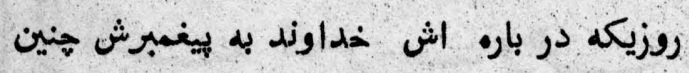

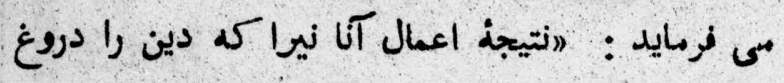

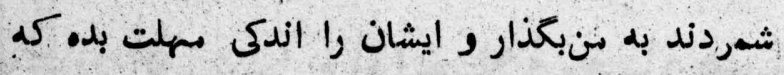

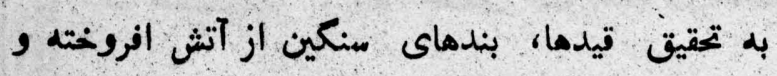

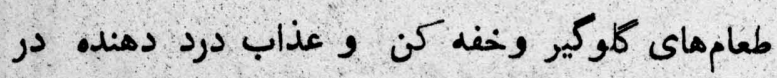

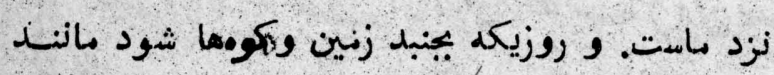

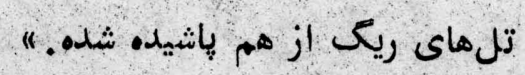

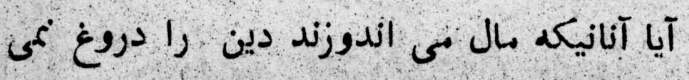

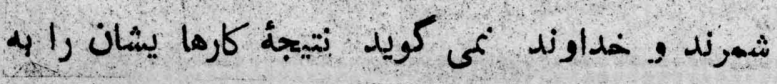

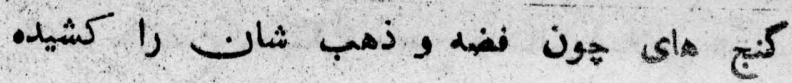
ثميتوانست تا اينكد در قعر زمين به رسوائى و ذلت ونه

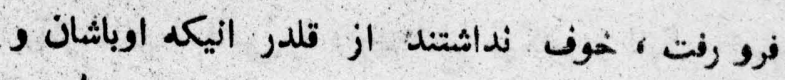

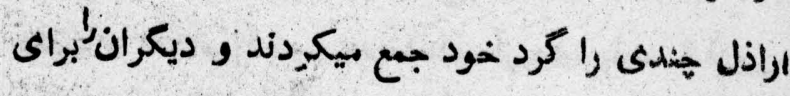
عبوديت شان تخويف و تهديد ميكردنــد ، و مكذا

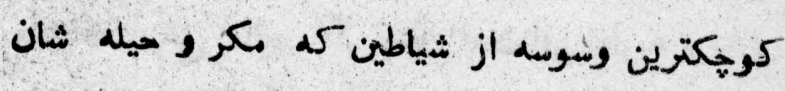

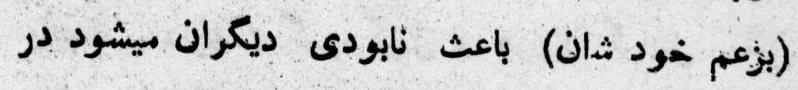

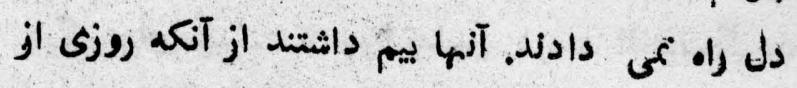
كردة ثان خساب ميكيرند و بايد براى مساب دمى دهى

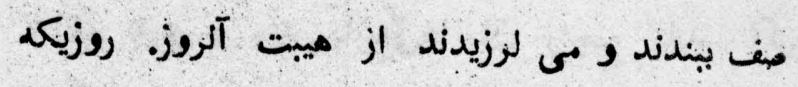

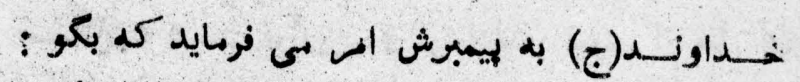

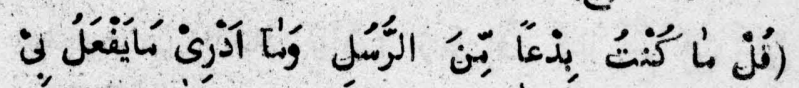

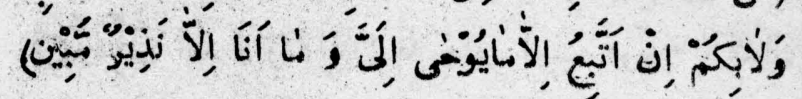

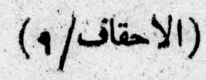

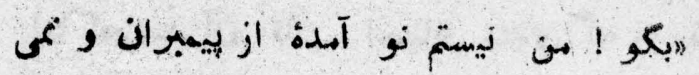

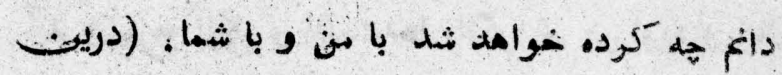

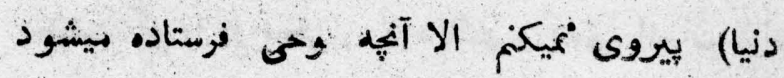
بسوى نن و نيستم من معر تر ساندة آشكاره" .

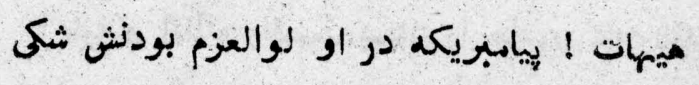

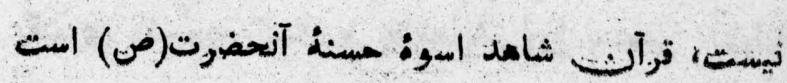

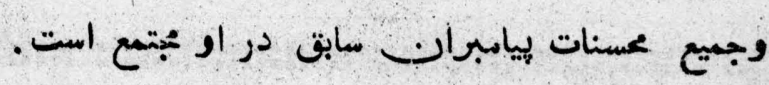
بآزهم از دعوى دانستن علمغيب ابا بى ورزدواز روز

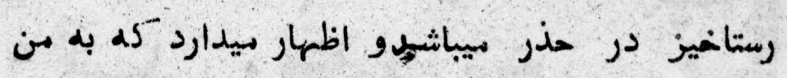

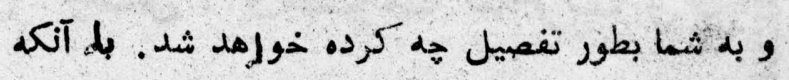

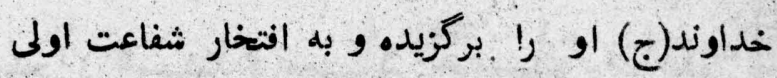

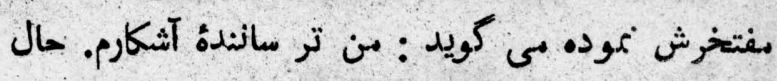

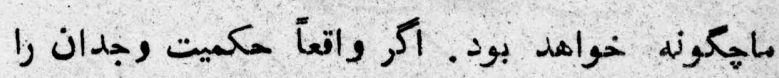

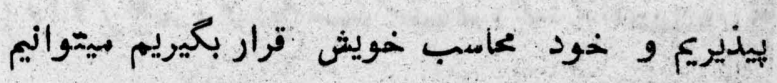

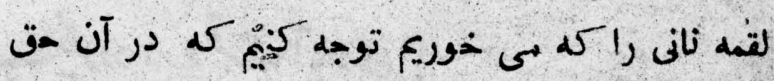

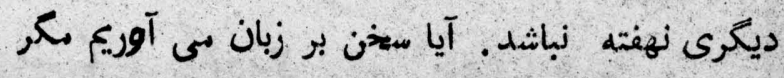
آنكه نفع شخصى وكروهى مان درآن مضسر نباشدو آيا 
غنتلف سازنده يك بيكرة: صحيع و سالم أسلامى هـت و يا اينكه با خنجرماى تيز و تيغماى آبدار جوارح

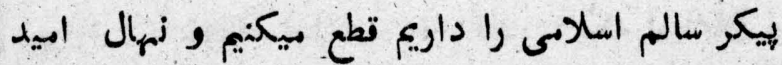

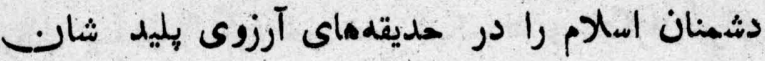

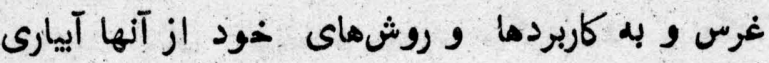

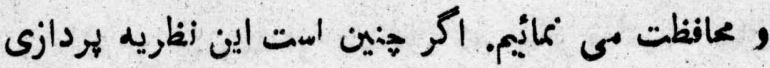

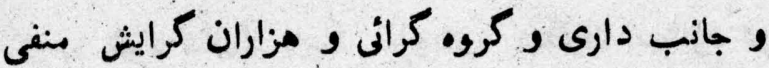
ديكر براى خيمت ؟ هرا تدابير درست التخاذنيكردد كه كينه توزى ها، دشهن ما مسدهاى مان را بزدايد.

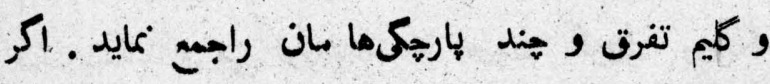
مشكلات هست ترآنـ و ارشادات نبوى از حل آن

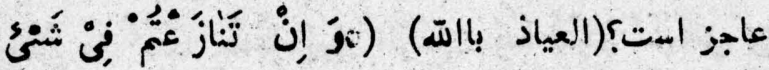

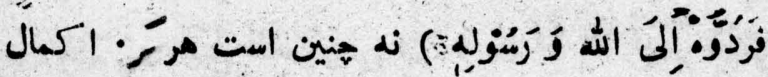
دين سشهود ونيازمندى ما در صورت رجوع مرفوع.

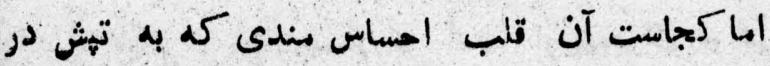

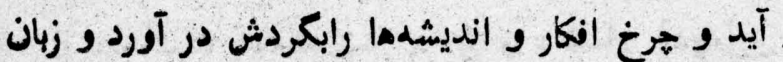

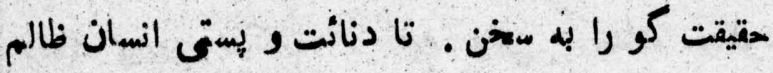

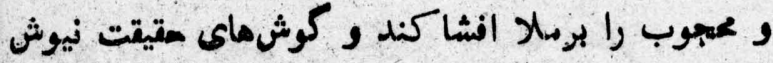
را باز، و انظار واتعيت بسند را بلب 'مايد ازين همد ششرى بانيروى ايمان و عقيده به روز رستخيز بيارايد
بن بكنار و براى هند صباحى بكذار كه با ناز و نعت

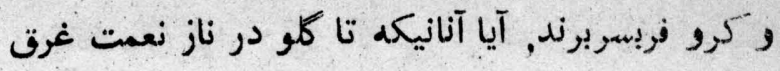

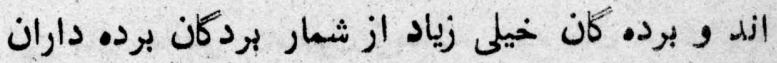
دورذ برده دارى تاريخ دست به سينه وصف بسته بر برد

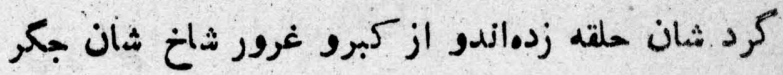

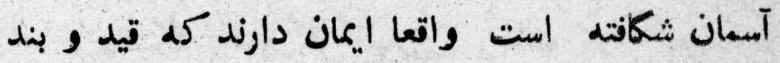
سنكين و آتشين و طعام كلوكير و عذاب درد دهنده

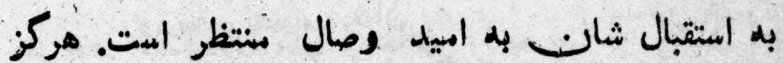

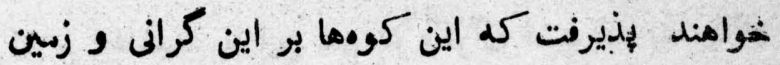
بدين يهنائى ياره بارد شود؟ نه هركز ! و خواهند ماش لله ذيست 3رشم از حساب روز حشثز

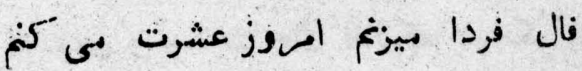

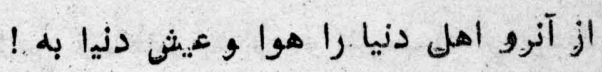
اين تفرق دملمين و موحدين هست كه فرمت

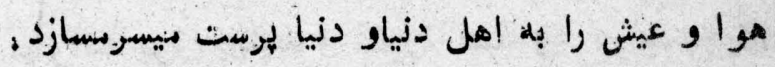

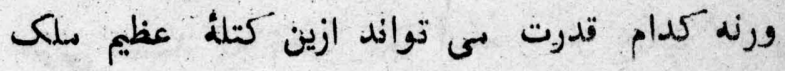

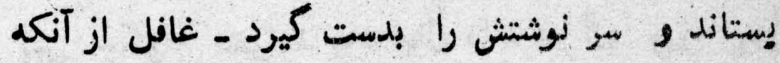
بدانيم إين همه تفرق وهند بيار هيكى وكرايش بذ نظرها

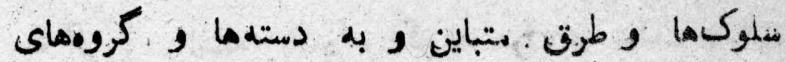


درين روز جزاى آناينكه زندكى به زرق و برق

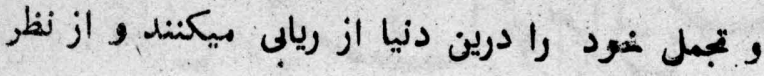

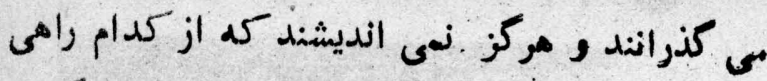

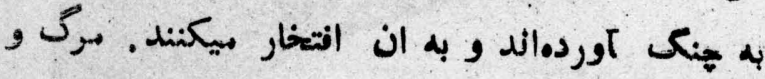

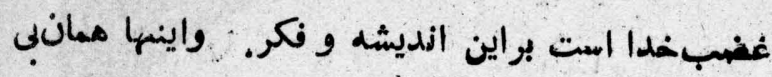

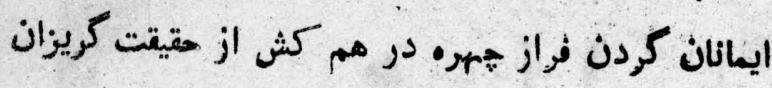

آرى سقر نصيب ثمان باد و نصيب شان همست (iاله)

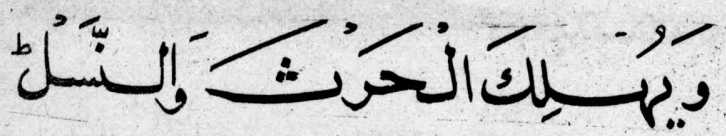

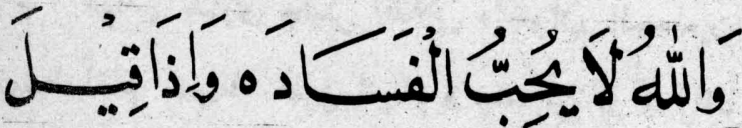

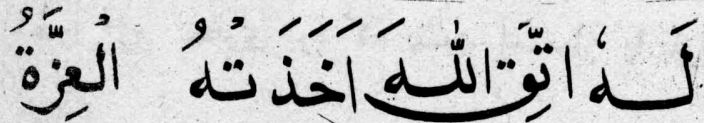

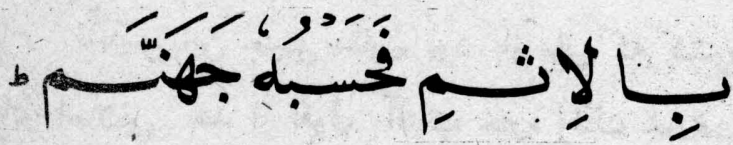

$$
\begin{aligned}
& \text { - ولَ" } \\
& \text { البقةق/R.r-r }
\end{aligned}
$$

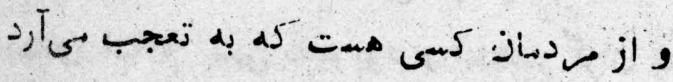

ترا سخن او در باب زندكانز دنيا و كواه مى آرد

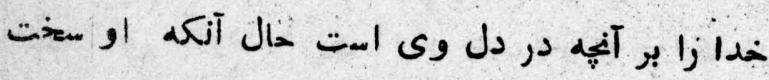

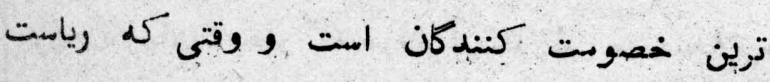

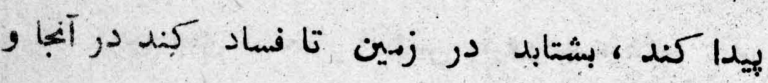

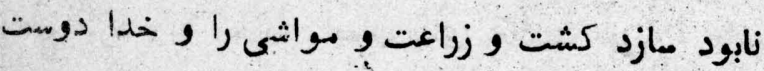

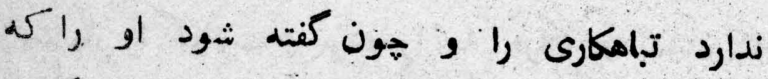

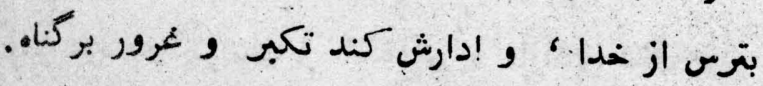

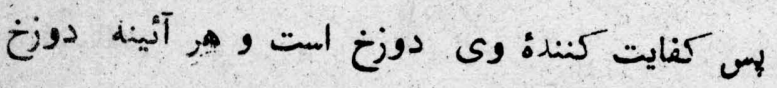

$$
\text { بدجائى امت. }
$$

تا علم توحيد را در روى زمين در امتز از در آورد .

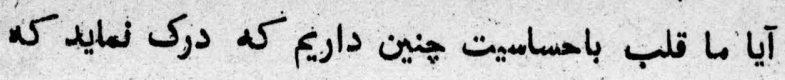
وظيفه دارد تافكر و انديشه مان را به آن وان وا دارد و

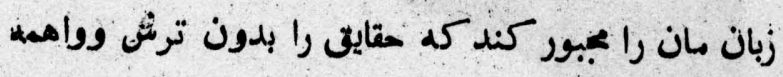

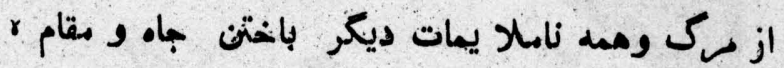
ثزوت و جالال اعتبار و عزت دربار بيان دارد اكر احياناً قلوب هنين بيدا ثود به فريادوفغانش كوشى فرا خوراهيم

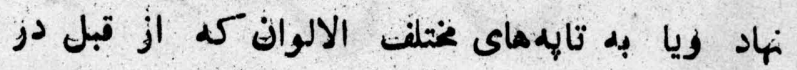
بغل تدارى ديده ايم به هنهو اش نه كوبيم ووابسته

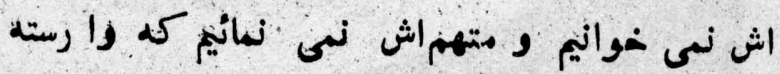

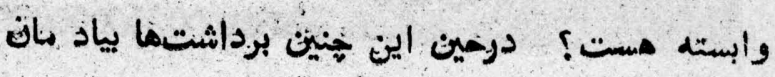

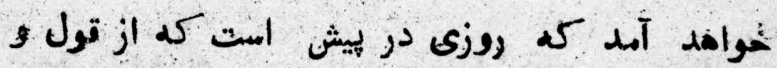

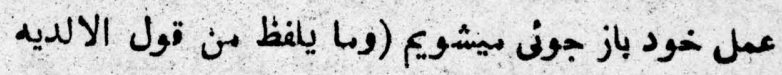
رقيب عتيد. ) آن روز روزيست كم هيتش را يروردمكاز

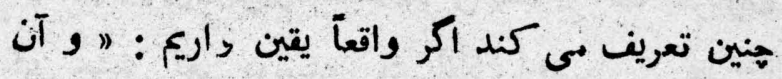

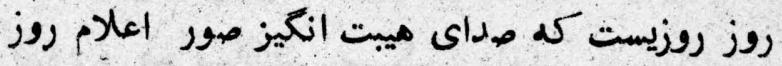

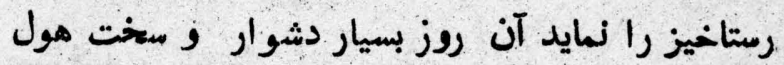

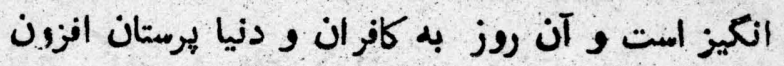

\section{طلب هركز آسان نخخوامله بود . ) اله رور اله}
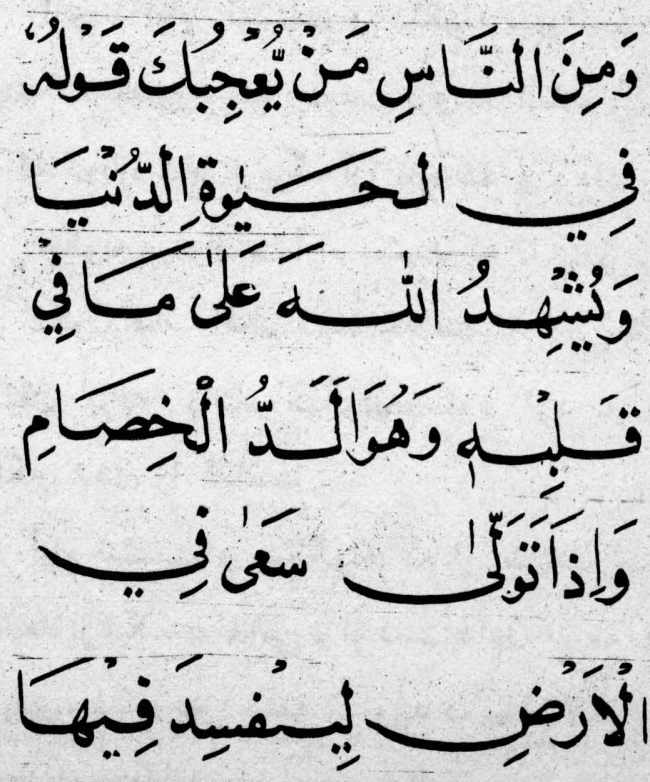


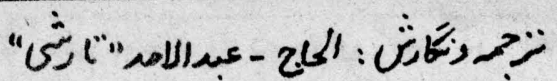
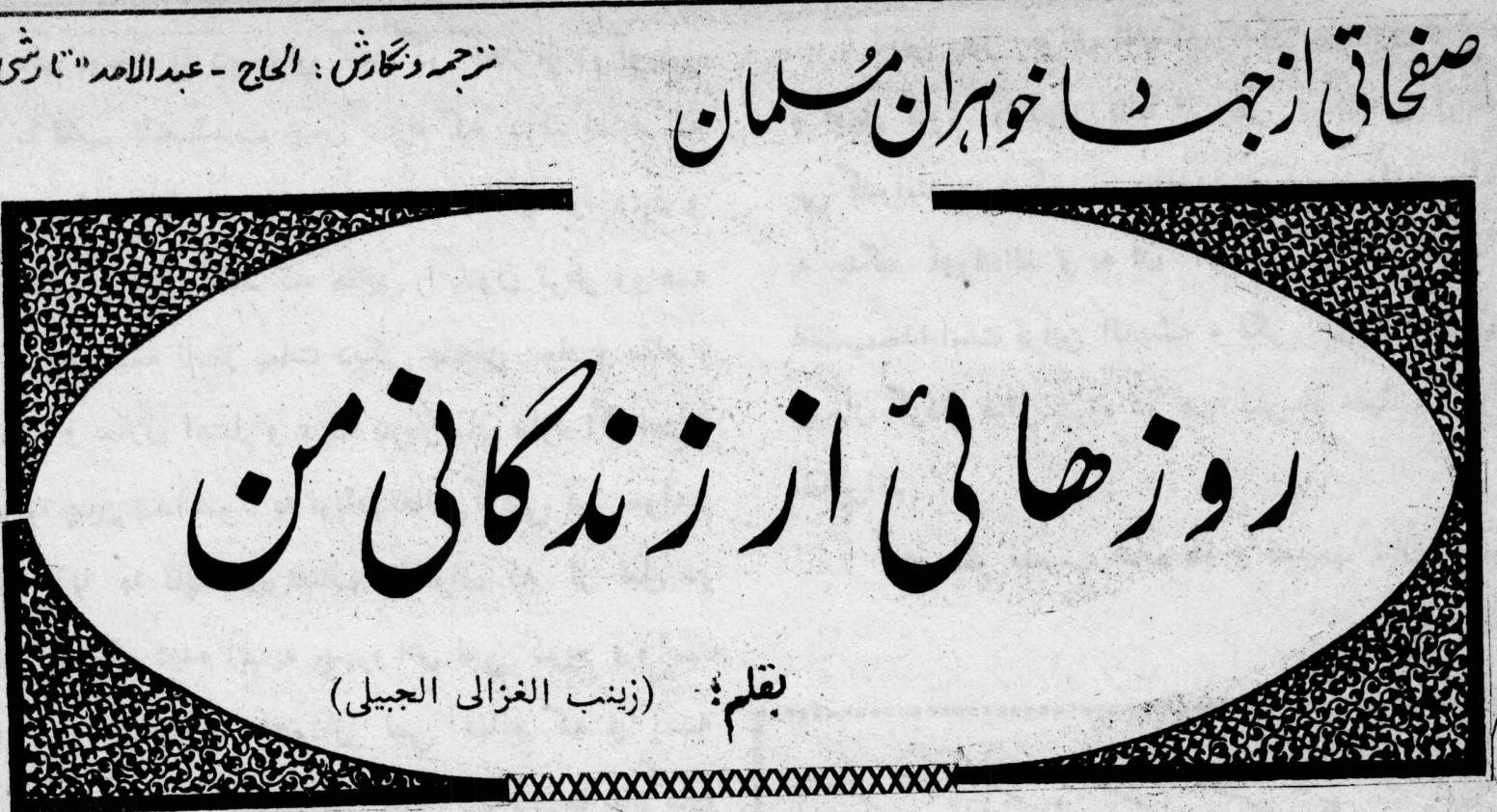

الماس كذارى جنبش انقلابن "اخوان المسلمين" شده. . دوباره در برابرش تلالؤ بيكند هرجه زورتر

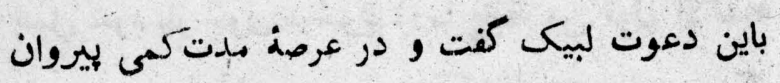

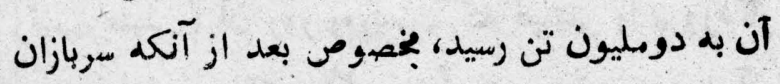
اين جنبش كفن يوشيده براى آزادى فلسطين برعليـيـه

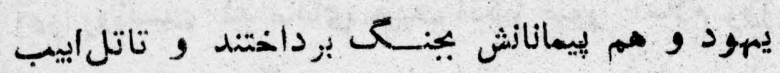

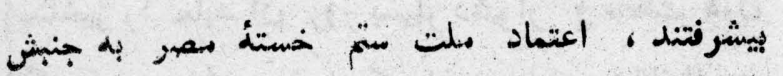

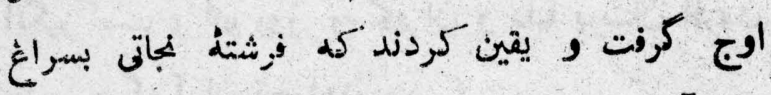
شان آمده است.

از طرن ديكر استعهار زيز آرام ننشست.

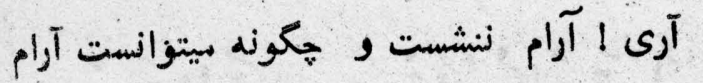

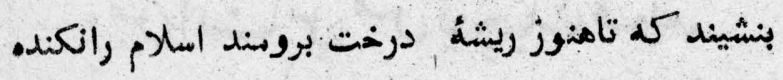

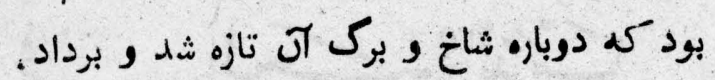

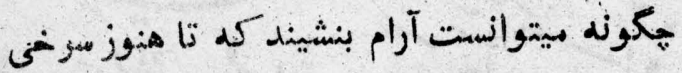

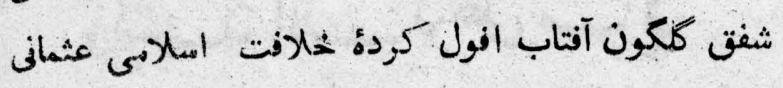

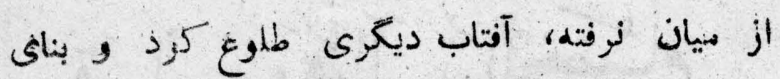
بهلنكير شدن را كذاثت. آرام ننشست و مهانكونه كد از طبيعت استعطار ابتهبعد از شكست نظابى و از دست دادن قدرت مقابلة

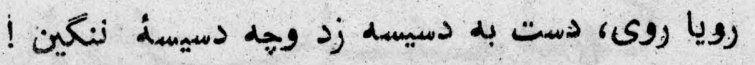
امام بزركوار جنبش "حسن البناء" توسط عمال

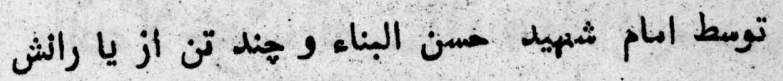

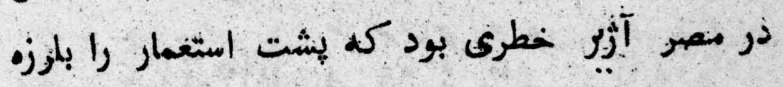
خر اورذ : ذان تأسيين اين بنبش مثارل بود باز مانى كم كشور

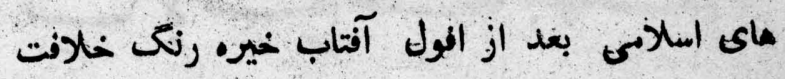

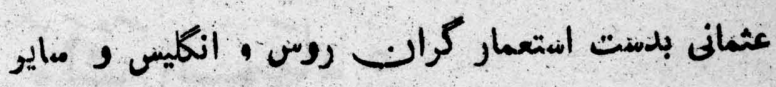

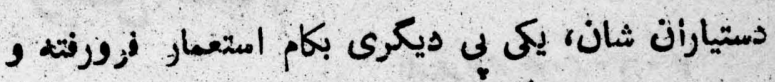

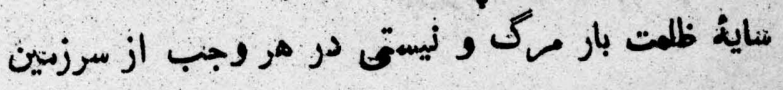

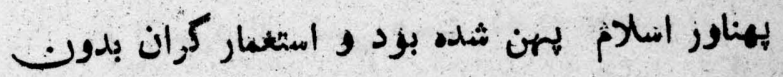

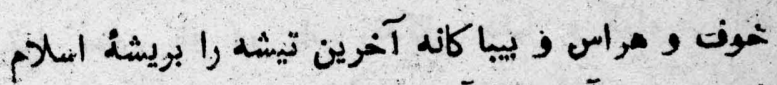

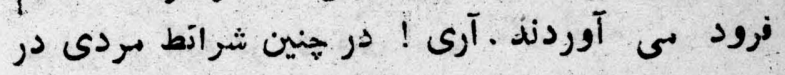

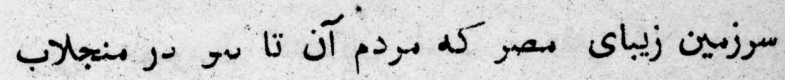

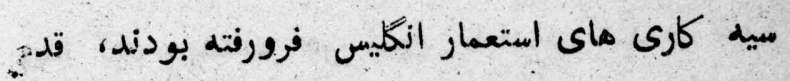

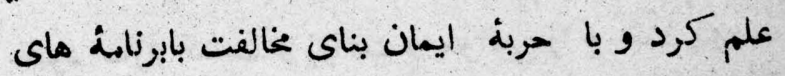

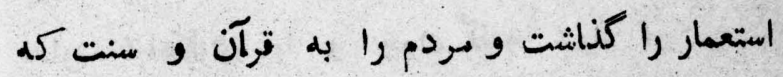
رمزي عزت وكرامت و استةلال و آزادى شان بود فراخواند. ملت مصر كه ميديد، كومر كرانبهاني كه با از

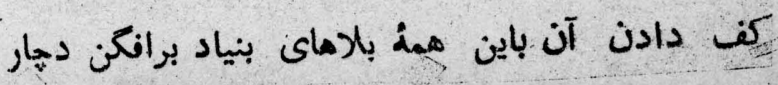




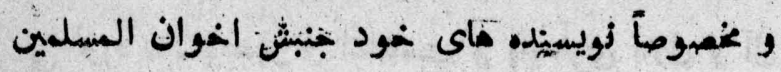

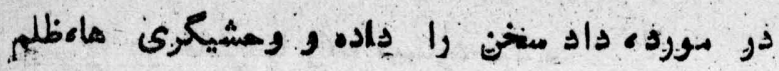

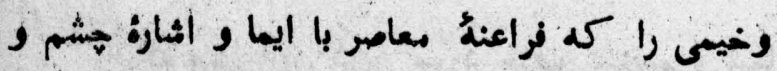
آبروى باداران ثان در حت علمبرداران حق و مي ميدوان فدا كارش كه براى المحاى بندكى بشر براى بشر د

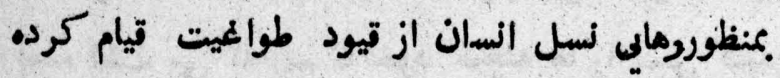

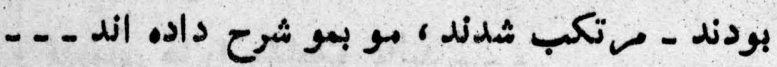
ييشتر اين حتايق تلخ و لكاكوار به دورة مياه

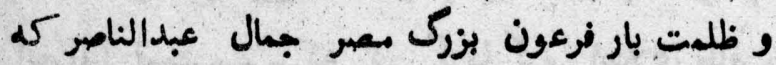

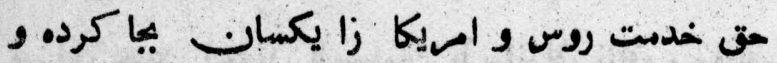

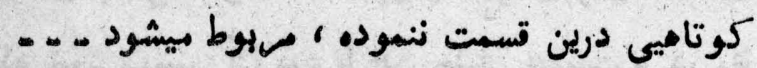
آرى در مهان دورو بود كم سهاميان كمر بستئ

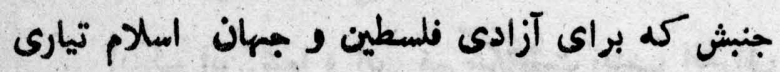

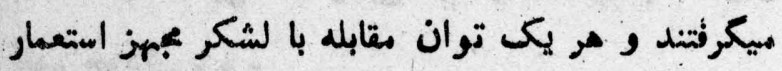

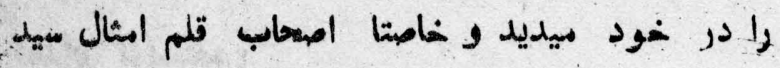

تطب و عبدالقادر عودة كم نيثن : تلمهاى برندة شان

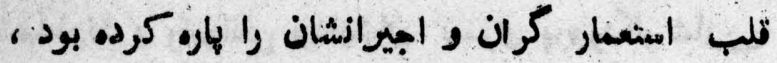

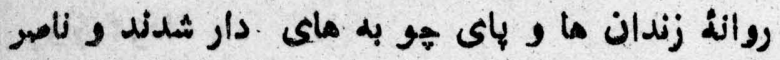

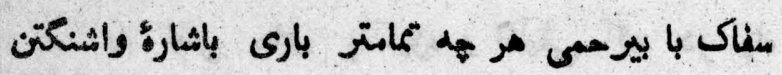

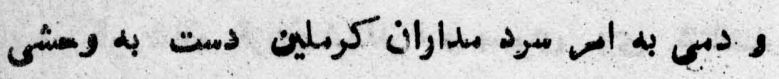

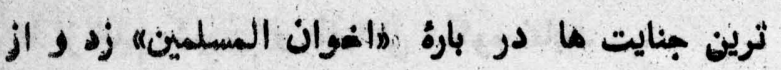

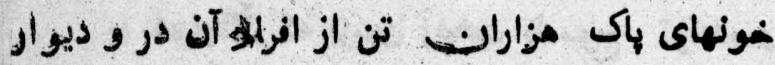

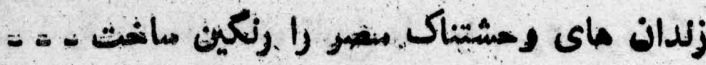

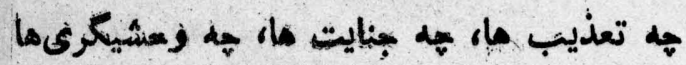

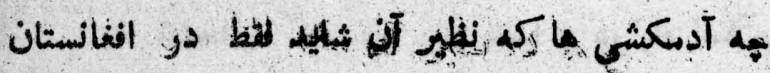

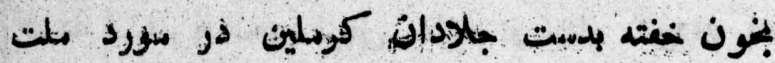

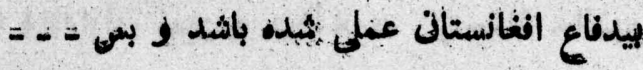
در بانب ديكو ثبات و استقامت و و بايدارثى

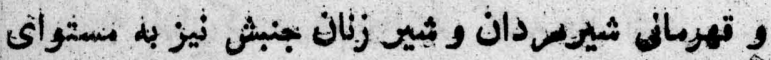
. صيد و استقاتى كم دوران ضلدر اسلام زا بياد
انكليه در توظئن خائهنانه در زمان مكومت فاروق كم باز يهزة بود بدست انكليسهبا، بشنهادت وسيد أما آيا

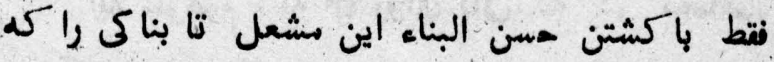

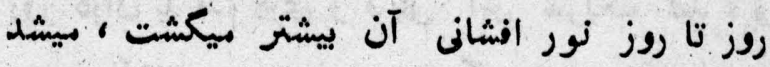
خاسوش كرد ؟ بوز روز

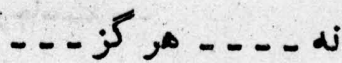

$$
\begin{aligned}
& \text { هر حه رأ سر برند جابـ بدمد }
\end{aligned}
$$

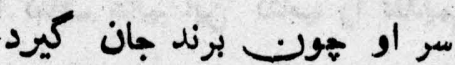

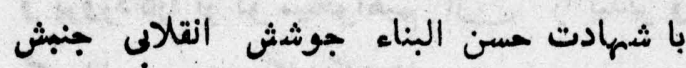

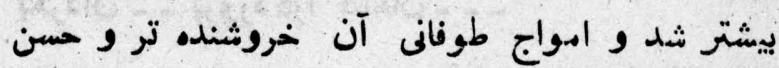

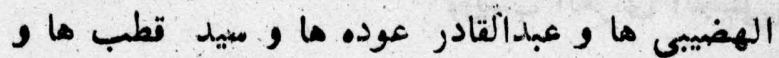

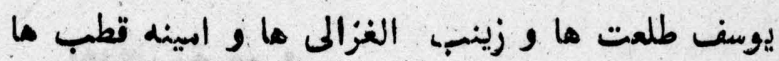

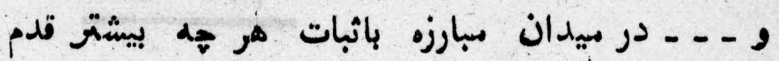

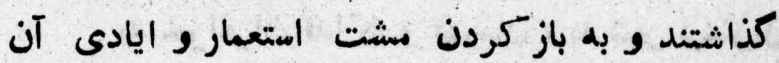
و رئم هاى طاغوتى و استعطارى لهرداختند ـ....

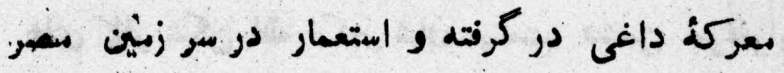
در مال نزع بود -... براى بيان خرباتى كه انكليسها از از تهرمانالن.

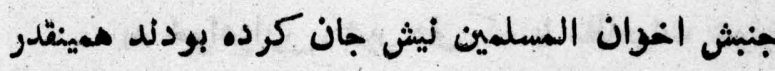
كافيست كد بكونيم يكتن ازين ابر مسدان تاريخ بنام

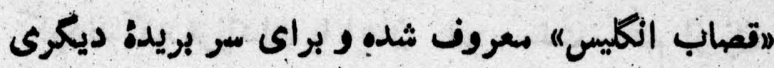

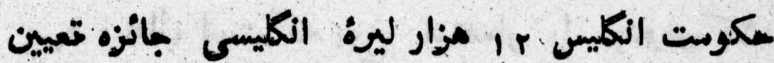
كوده بود - شبرح قهرمانف هايى مر يكى از افراد بانباز

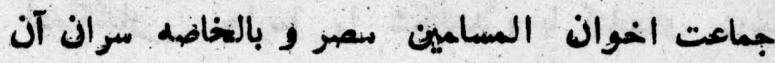

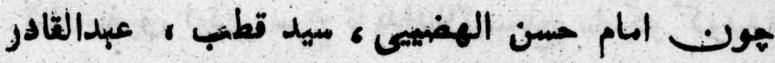

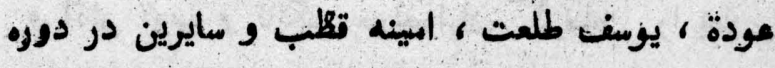

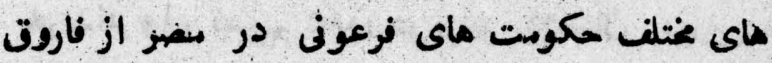

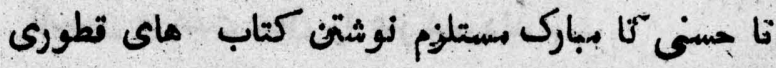

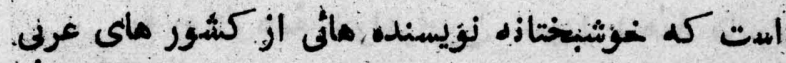
و غير عرى - سملمان و غير مسلطان دوست و دشمن 
زاه خملا زميده بود و المساس ضعف نكزدند و تسليم كأشتند -

به شوهرم ، به آن روان بإكى كم ذر ذر مصانب

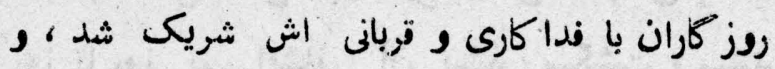
بعد هم آن روح بششثند. و ايثار كر به عالم بالا شتانت

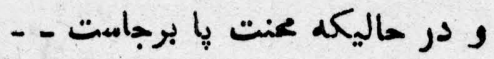
براى همه اينها و براى همه مسملمانان در همه اطراف ـ أكناف عالم اين كتاب را تقديم مى دارم و يروردكارا از تو ميخواهيم آسـ را بهيذير و نافعش

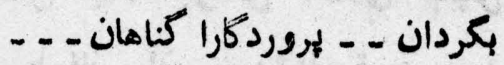

(زينب الغزالى الجبيلى) (- (زيل)

\section{المداى مترجم :}

به خو اهران فدا كار و قهرمان ، به شير دختران ر شير زنان سماهاذ افغانستان به آنهاني كه به نعره

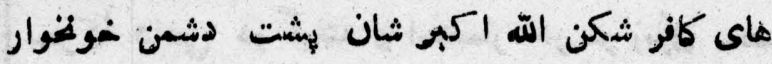
ر وحشى را بلوزه آوردند و با نهونهاى باك شان نهال

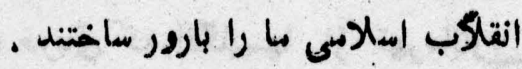
به خواهرات شير دلى كل با مظاهرات خوئين و ثياسهاى بي در بي به ديو جنايتكار كمونيزم ثابت

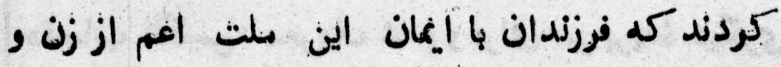
مهد ، معال است كه يوغ استعمار را بردوش كشئد

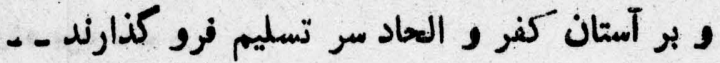
به خواهران مبارزى كه با نوى قلم ، ثلب

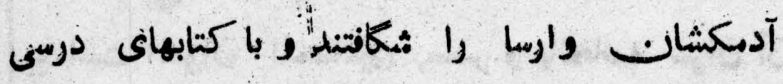
شان بفرق ارتش سرخ ثا بدندان مسلح ماسكو كوبيدند

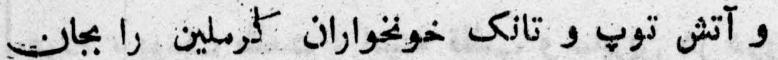
خريدند ولى تستيم شدن در برابر دثهنان ديـــ و كابوس و عفت شان را عار ثهردند - -

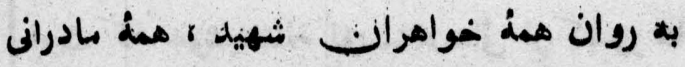
كه با بكر كوشكان شان در اثر بمبارد هاى وششيان

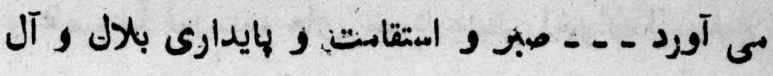
يإسر را در خاطرهما زنده ميسازد - - =

اينكه بيش ازين درين مورد خرف نميزنيم و شها را در جريان ان حوادث و آبـ قهرمانى ها كه در زندان هاى مصر و بر سر يكتن ازجابازان اين مكتب

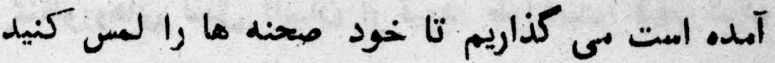
و قهرمانى ما را مشامده نمائيد -... اين قهرمالب ، خواهر رزمنده و مجامد زينب انغرالى است ـ... كم در كرما كرم ابتلاى طاقت فرساى جنبث الهوان المسلمين با مازمان زنان مسلمان

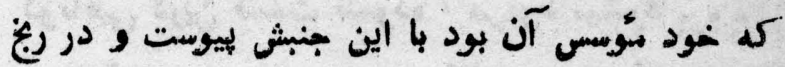

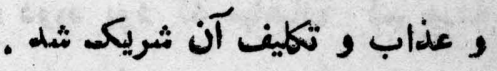

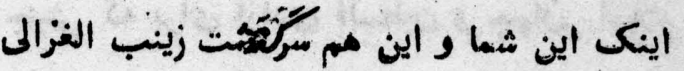

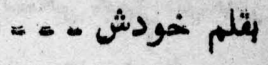
الهاى لمويسنده :

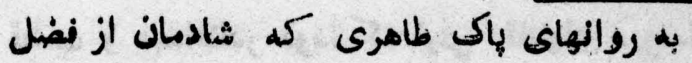

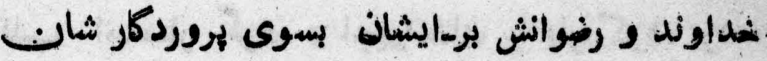

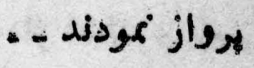
به نغس هاى باكيزه و نظيفى كه در راه هرودمكار شان قربان شدند ، و بسوى وى شتافتند

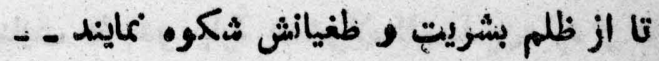

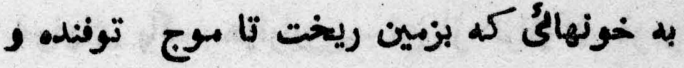

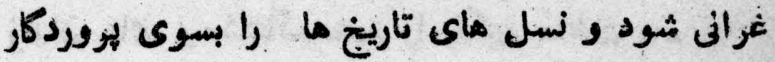
شان سوق دهد - ـ مان

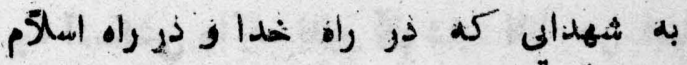

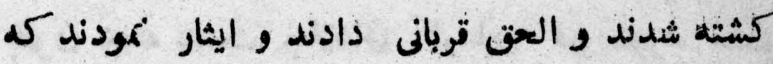

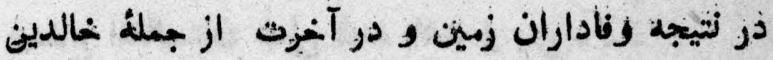
و

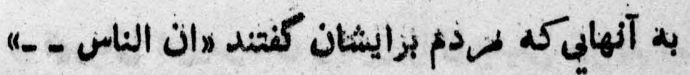

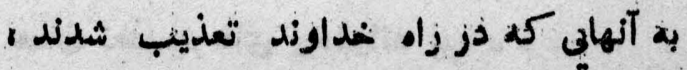
يسن سنست اراده زشدند به سبب آزهه ايشابـ زا دز 
باميد بيروزى نهاني ارتش اسلام در افغانستاذ

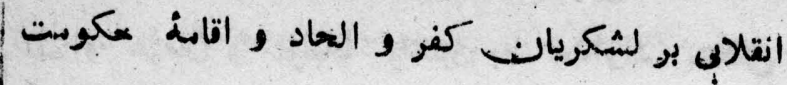

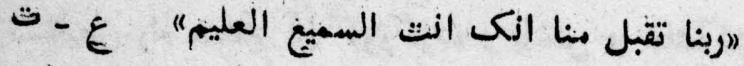

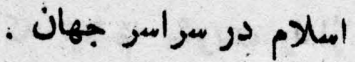

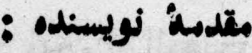

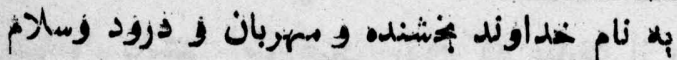

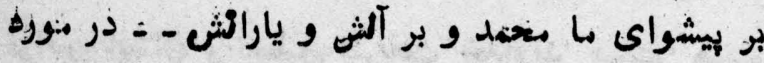

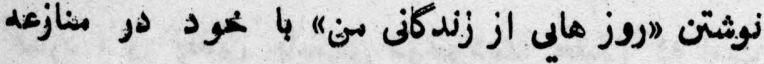

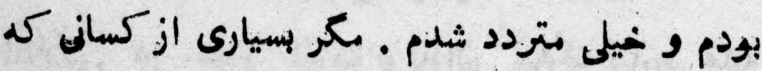

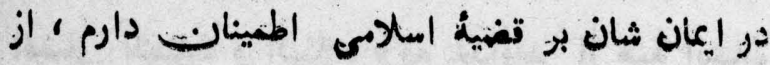

جملة فرزندان و برادرانم بيشواى دعوت و بانياس.

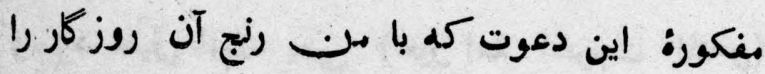

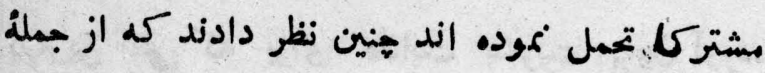

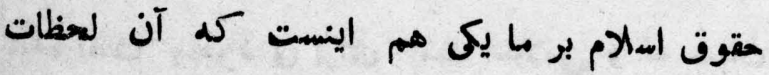

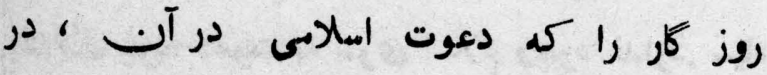
بجبوهن عاربة نيرو هاى الهاد و باطل در شرق و

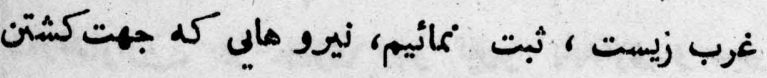

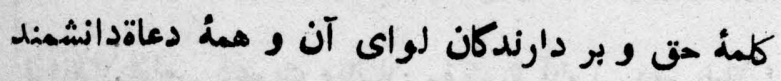

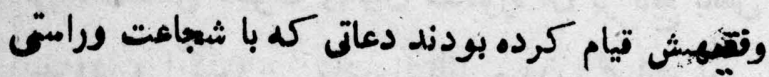

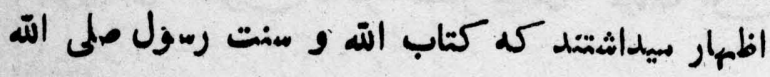
عليه وآله وسلممعطل مانده الست و بايد اين دو مشعل

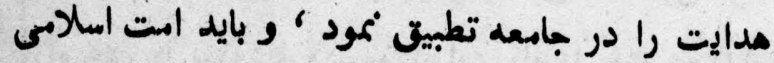

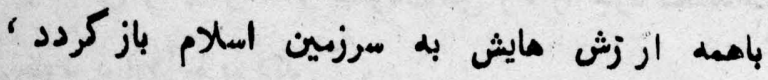

رونهاى ستمكز در زير خهروار ها غاكل زنده بكور

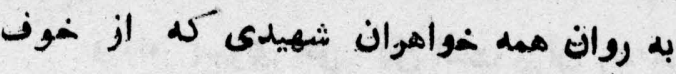

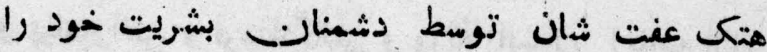

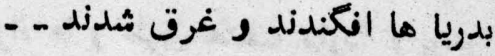
به روان همة خواهران شهيدى كه در زندان

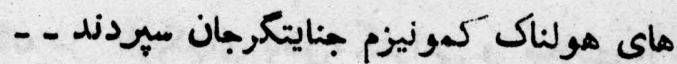

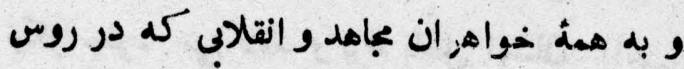

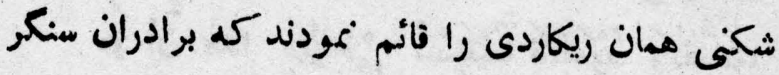

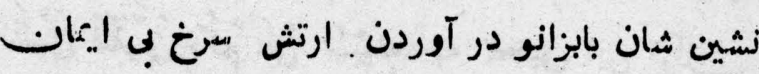
بآن دست يافتند -..

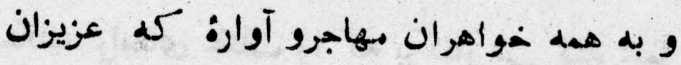

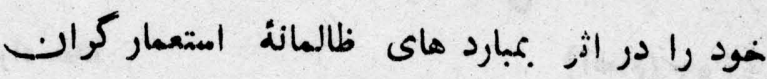
درزده خوى اردو كاه كمونيزم ويرانكر از دست داد داده

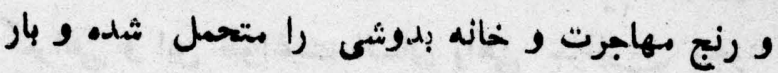

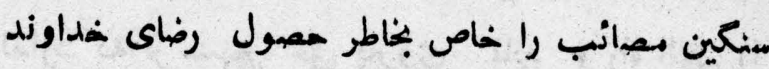
و باميد اقامُ مكومت عدل الههى در انغانستان بخون

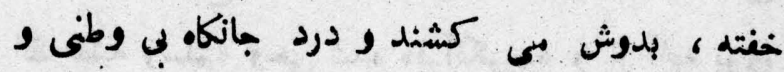

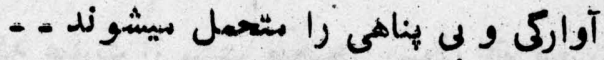

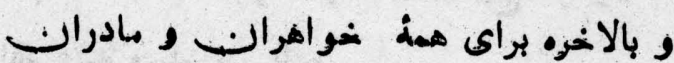

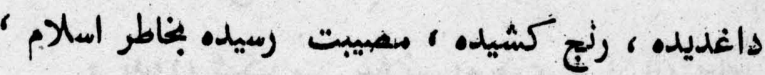
تربعه اين كتاب راكد شمل از شرح زلئدكانى شمواهر

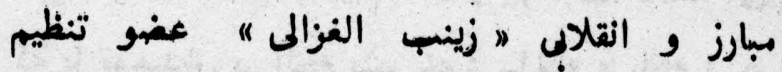

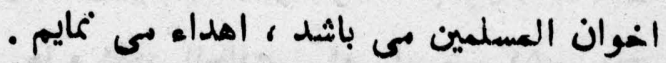

(e)

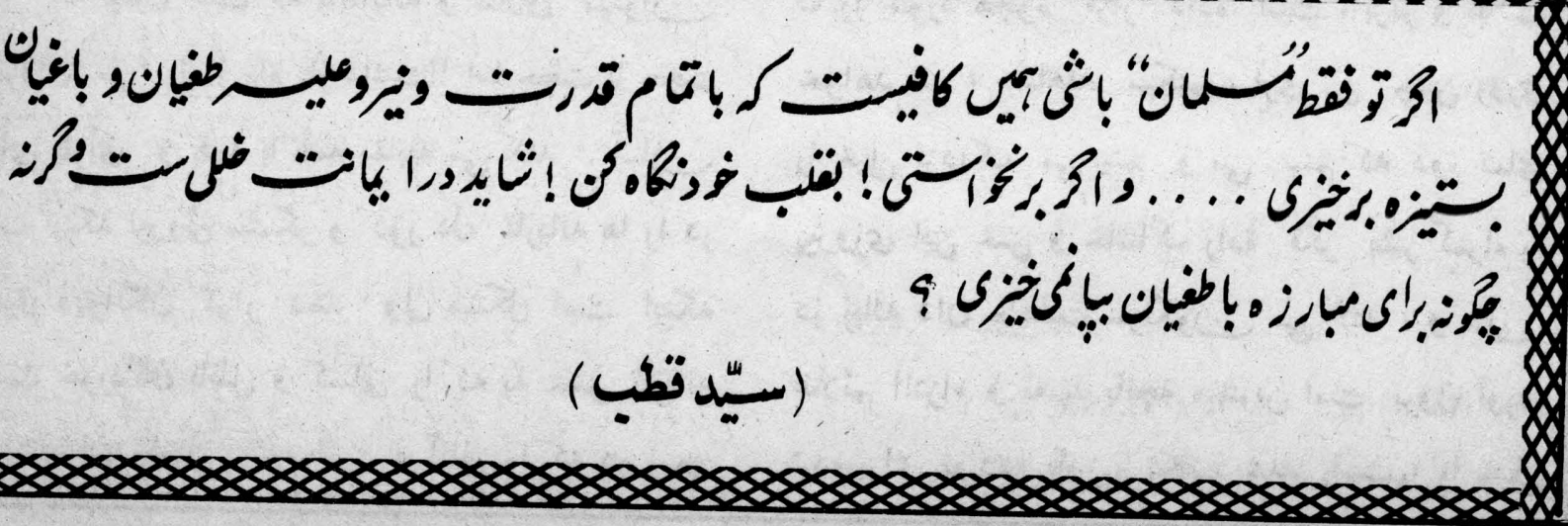


دعواى الوميت مى كنيد، از طريق كراهى فو جهل

شان لاز داثت و به راه راست مدايت شان كرد م. ور راه بسوى حت يكى است و آن راه خداوند و بيابمرانش و فرستادكانث و ورثن ايشان (بياببران)

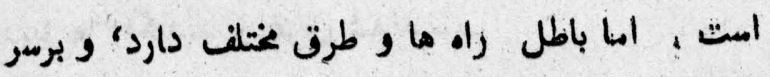

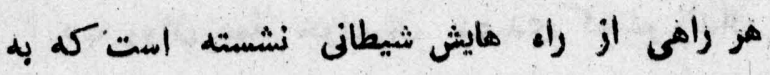

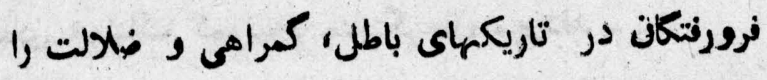

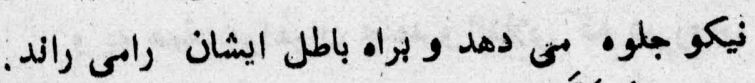

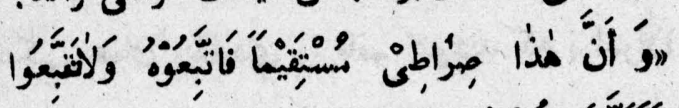

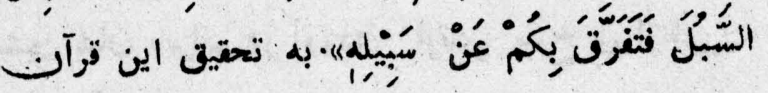

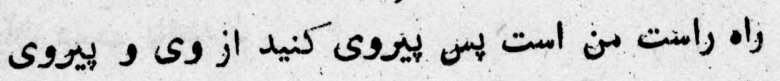

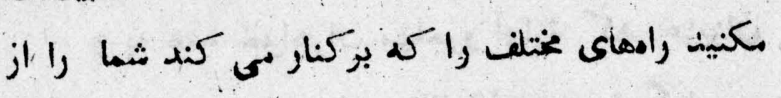

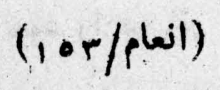

| اله

و امهوز بيشتروى بشريت براى رماقى ازيســ

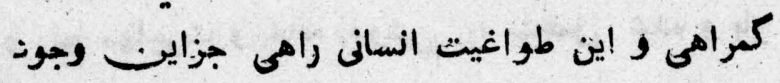

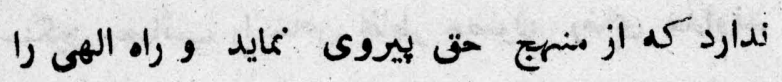

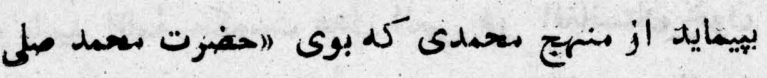

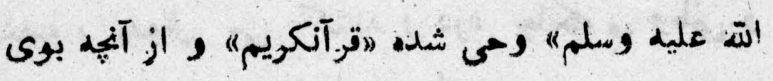
الهام شده كله عبارت أز سنت صسيح رسول الهه صلى وسلى اله عليه وسلم بى باثهد

و بدون شك من علانم ييروزى و نشانه هاى بلى

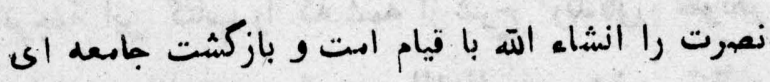

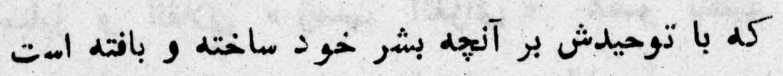

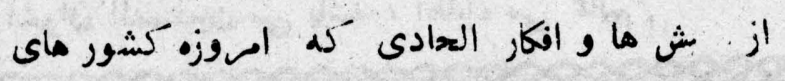

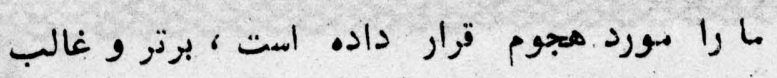

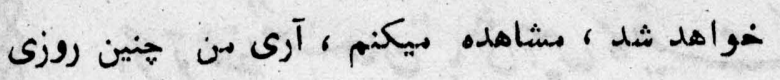

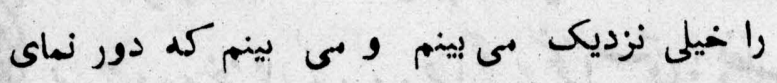

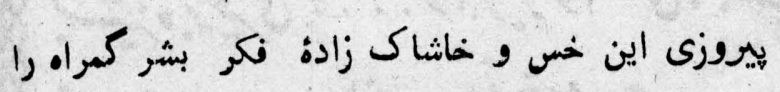

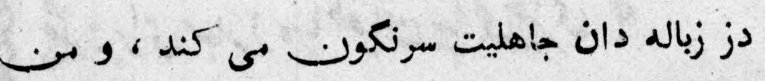

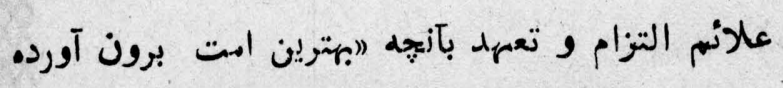

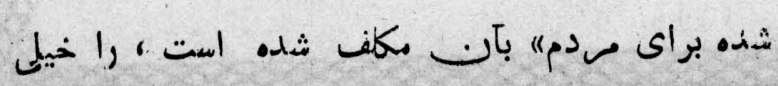

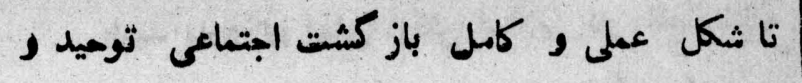

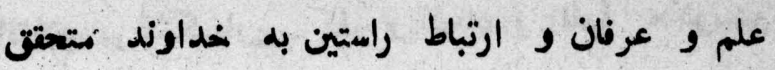

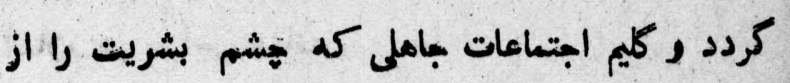
تشغيص راه مستثيم آن كوركرده و باخس و ماثماكث ونش

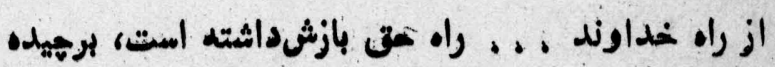

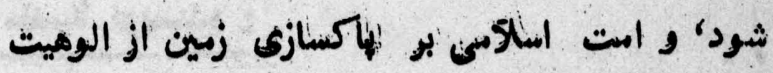
بشر و لمرستش طواغيت زمين كه عبارت از يردون

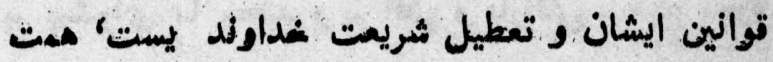

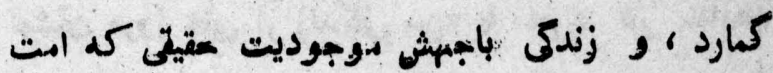

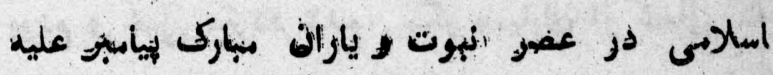

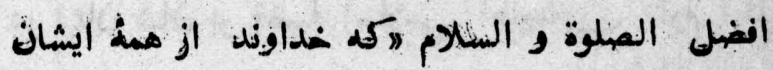

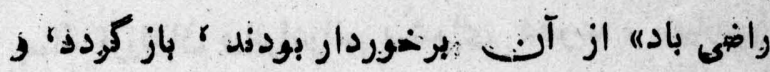

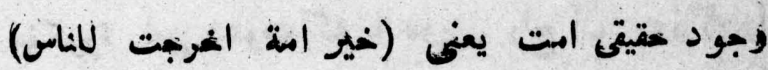

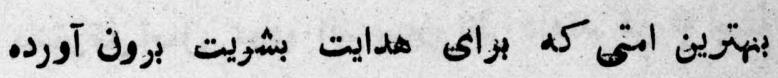

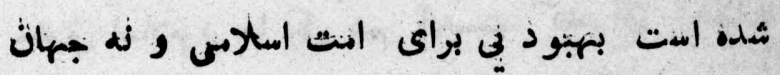
بشريت جزبه دعوت به سموى اسلام وجود ندارذ. سيان

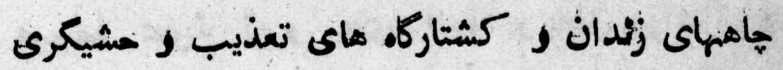

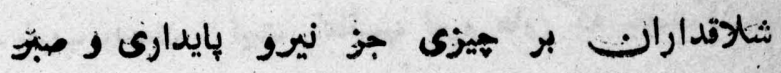
فرزندانغخلص دعوت وبانيان مفكورة آن بر دنع باطل، لفز

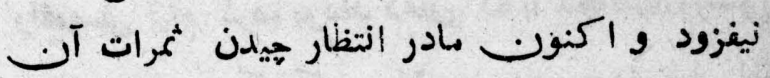

و هم بدين سان بود روزكار آنانى كد قبل از ما

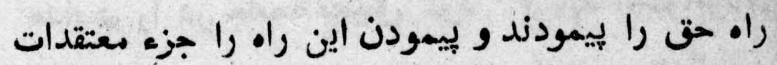
خود قرارداده بودند. نه ينان است كه باتازيانه و شلاق بيتوان.

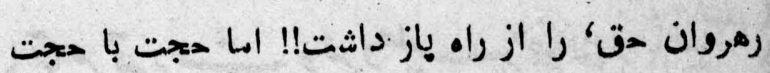
ورأي، بارأى و كلمه باكمه مقابله مي كند ، آساب.

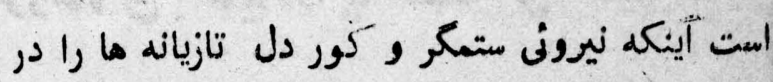

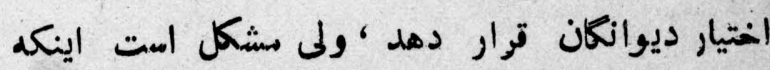

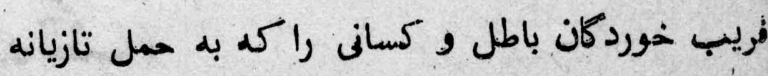

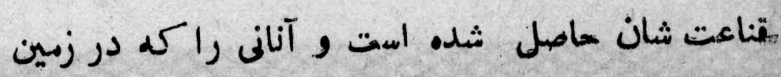


اثهكالش ، آن روزكار را جهنم ناميده اند !!

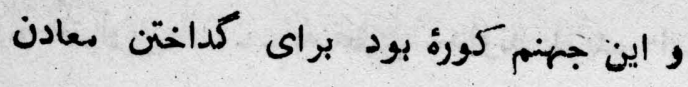

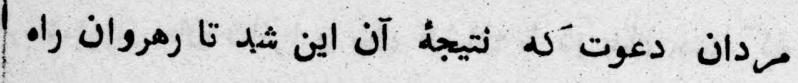

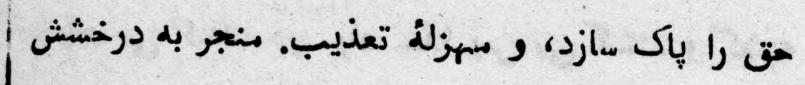

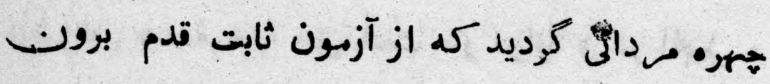

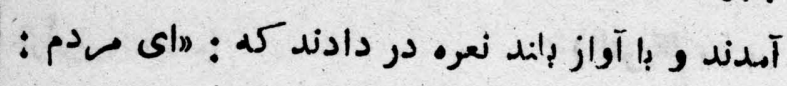
أسلام فقط انتساب نيست بلكه تعهد و بيروى استه" . از خداوند ميخوامم مسا به شرح و توصيف لنش

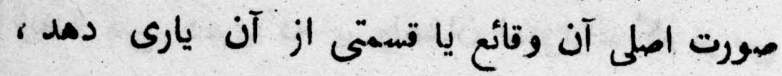

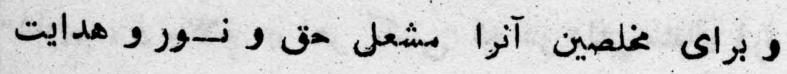
كر.داند.

بس بايد براى كمانهايعان صواط المستقيهى را باز

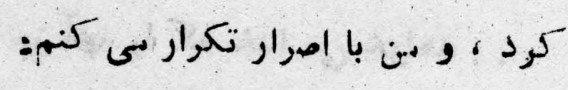

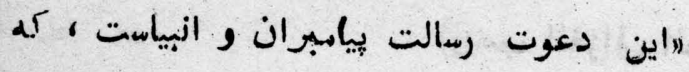

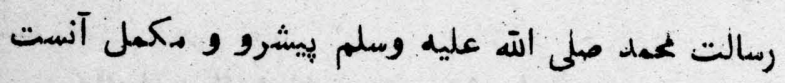

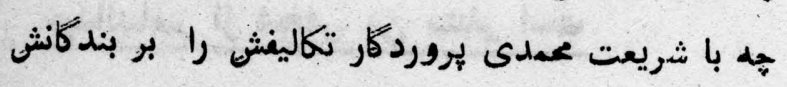
تكميل كرد و هم با آنـ شرائع ما قبلث را منسنوخ

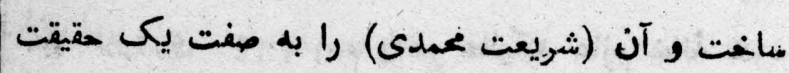

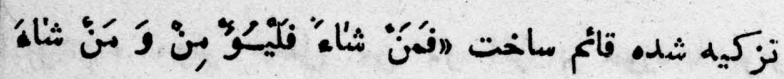

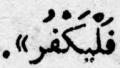

بدون شك آنهائ كه رنج نامهوارى راه را تحمل

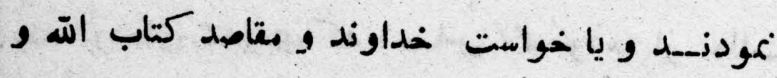

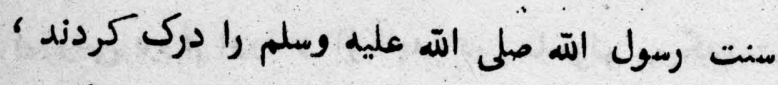

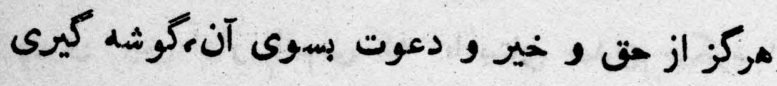

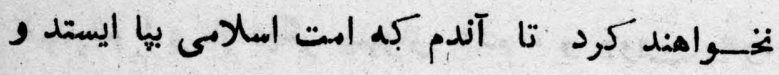

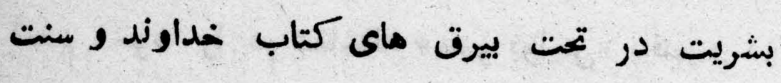
رسولث استقرار يابد. و ما مبطئنا بر رامى كم بركزيده ايم استقامت

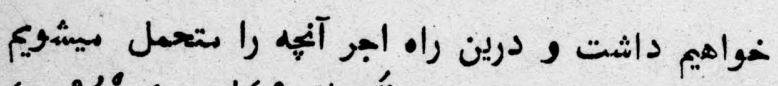

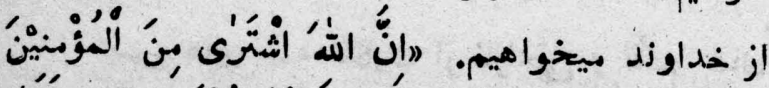

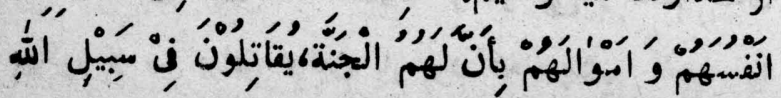

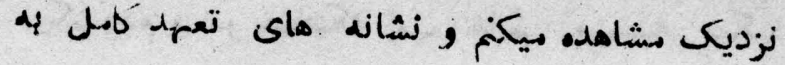

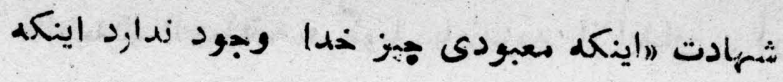

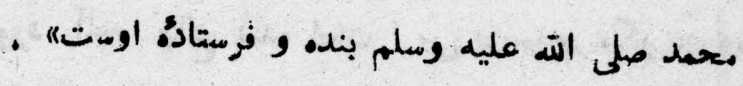

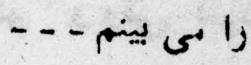

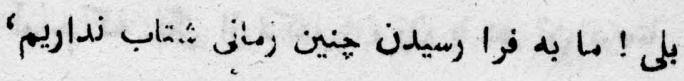

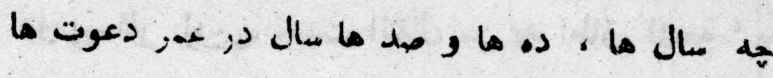

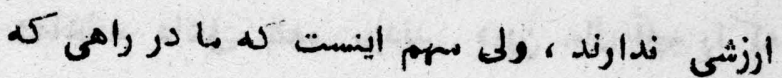

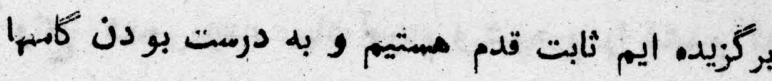
و روشن بودن بينث هايمان ايمان داريم.

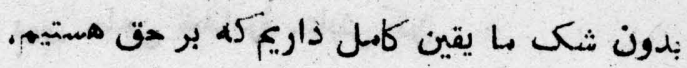

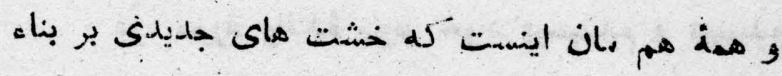

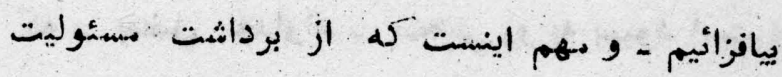

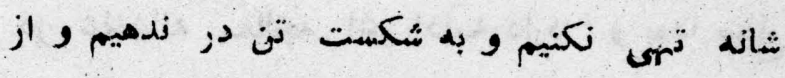

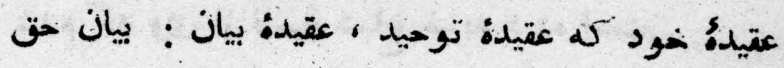

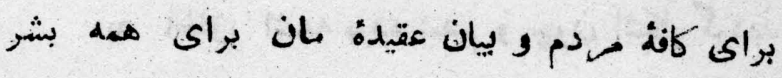
است ' دست بردار نشويم: با أعمان مان بر اينكه روزكار زندان و تعذيب

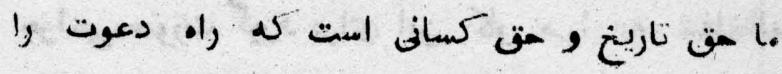

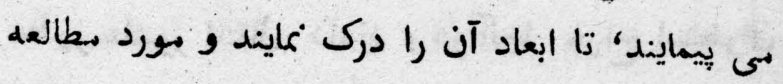
اش قرار دمند تا براه جهاد ثابت قدم باثشند و قضين

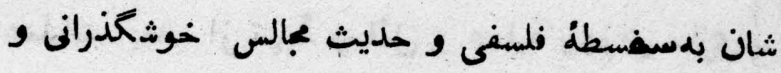

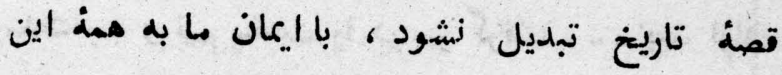

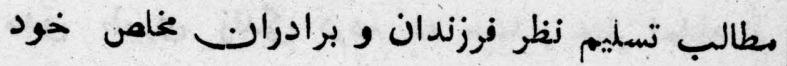

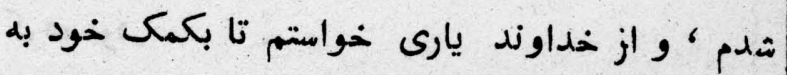
كرد آورى آنجه در حافظه ام از آن وقائع (وقائع زندان

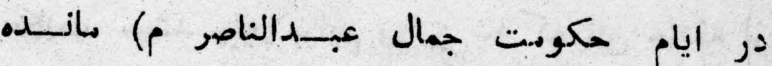

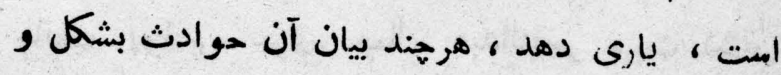
صفتى كله بود ، مشكلمل امت.

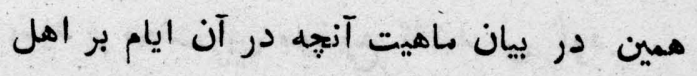

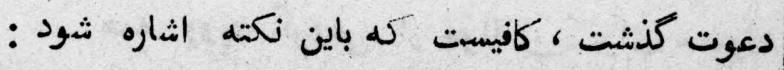

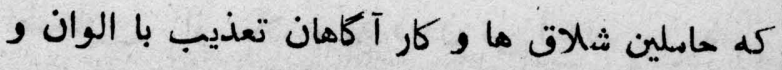


ميكشودم و در حساليكه لب مايم زمزمسه ميكرد

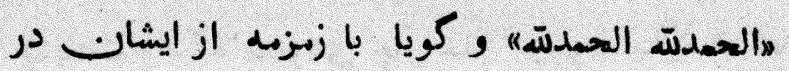

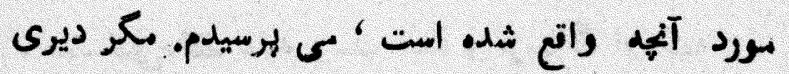

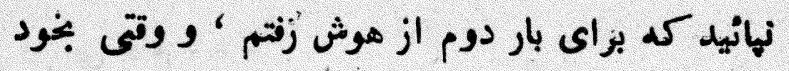

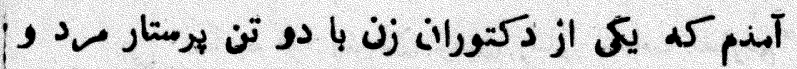

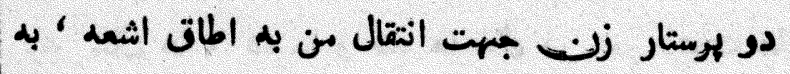

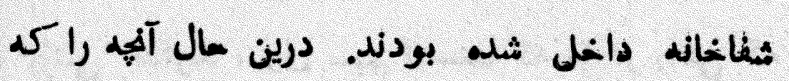

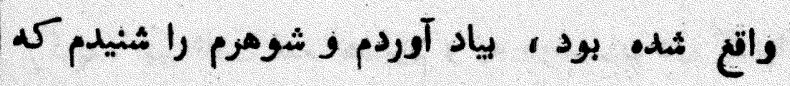

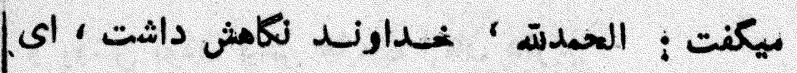
بابل حاجى شدا را ستايش كن. در مورد رانندة موتر خود برسيـدم و فهميدم

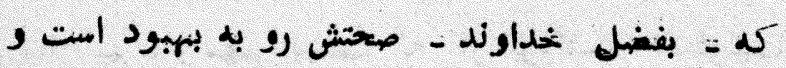

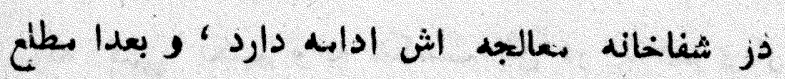
شدم كه وى از ناحية دماغ ضربه ديده است. به اطاتل اشعه برده ثدم و جيون آشكار كرديد

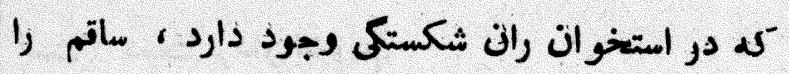

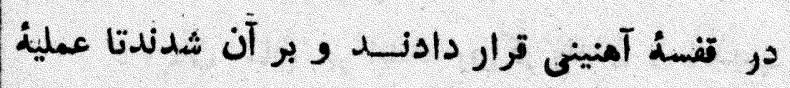

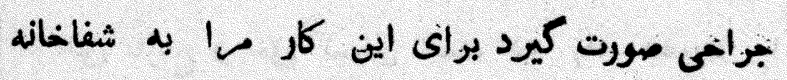

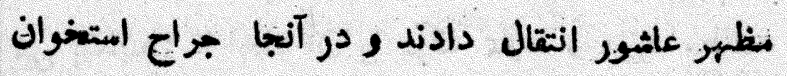

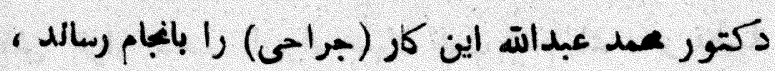

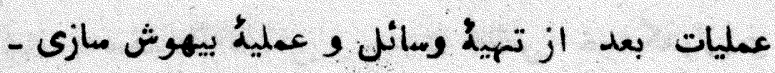

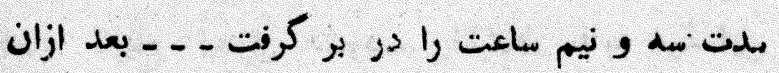

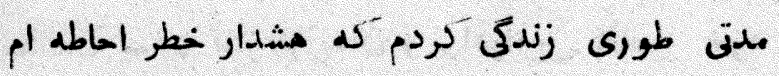
كرده بود.

ايام خطر كذشت و با جمع آورى آئه كغته و حكليت ميشد جنين برايم روثن شد كه اين حادثه از

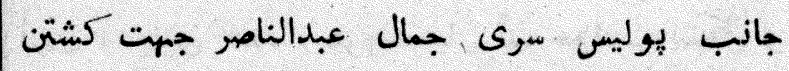
من طرح ريزى ثده بود و اخباريكه متواتر برايم

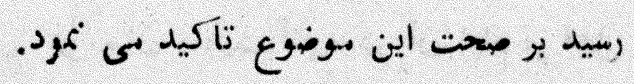

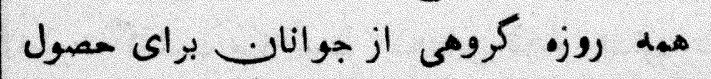

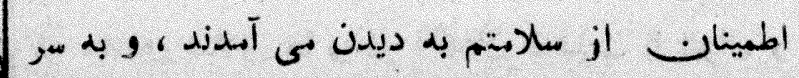

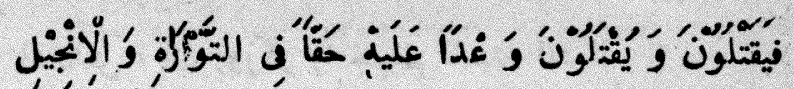

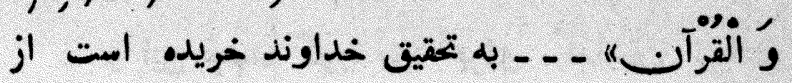

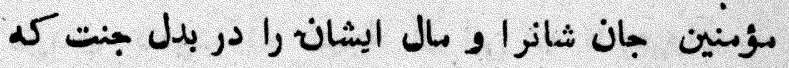

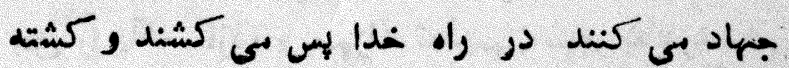

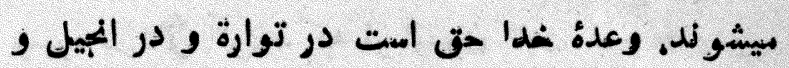
(التوبة/11)

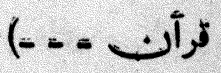

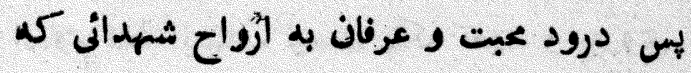

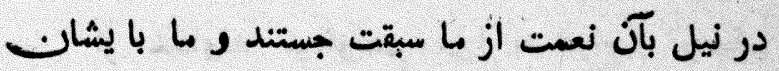

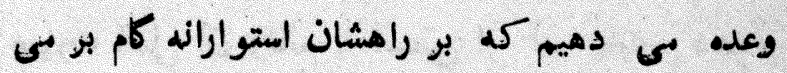

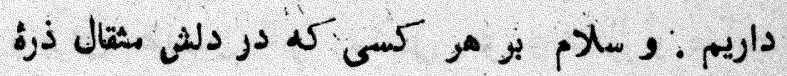

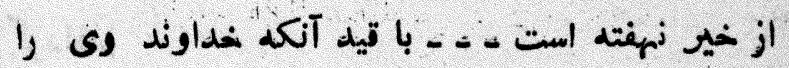

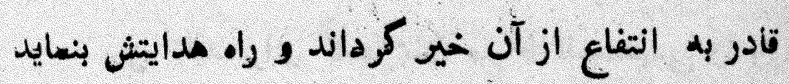

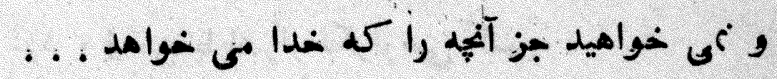
(زينب الغزاله البجييلى)

\section{عبدالناصو از شخغن من متنفر است}

در شام روزى از روز ماى تابستان و در اوائل

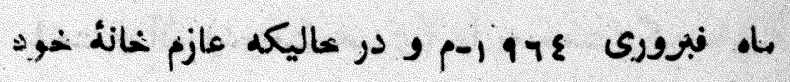

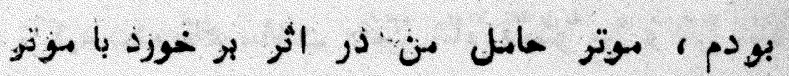

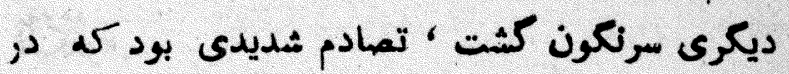

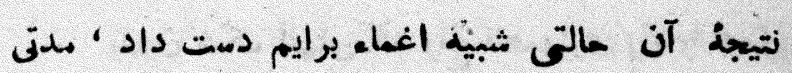

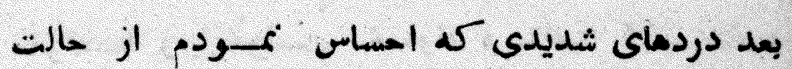

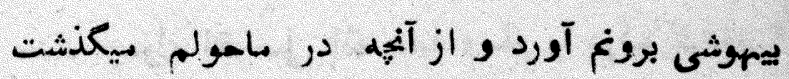

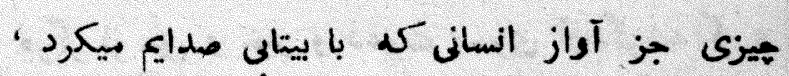

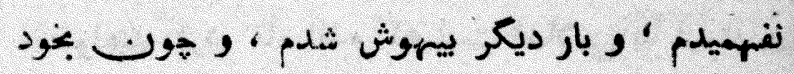

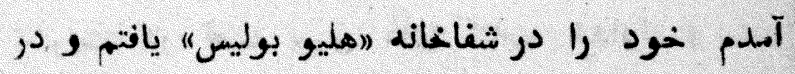

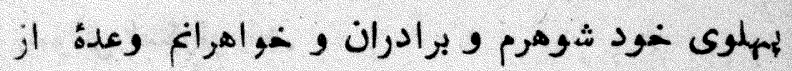

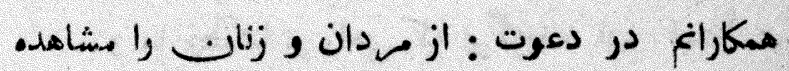
كرد بر.

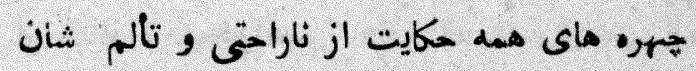

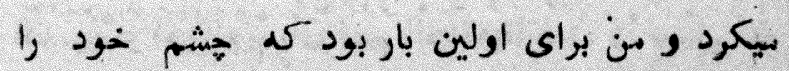


أتخادم و از شوهرم سبب را إرسيذم ، وى دليل آورد

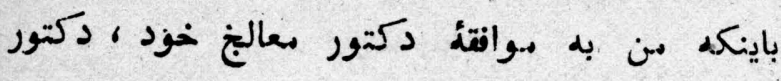
عبداله لياز دارم.

ثوهرم بنزد د كتور رفت و لحظاتى بعد با دكتور

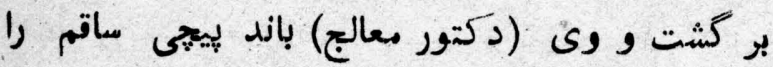

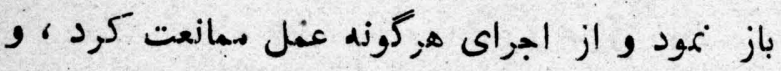

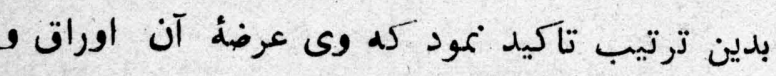

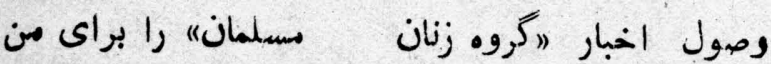

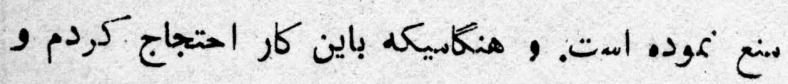

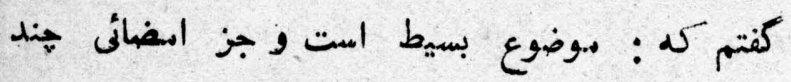
با آن اوراق كارى ندارم ، وىى باصرار خود افزود ـ. بعد از كذشت هند روز از طبيب التماس كردم : اجازه بدهد در مين اينكه در بستر مريضى هستم

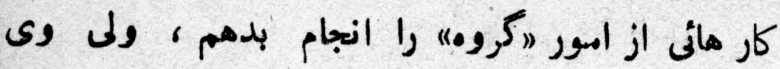
اين خواهش مسا نهذيرفت ، و يقينم بر ايــ بيشتر

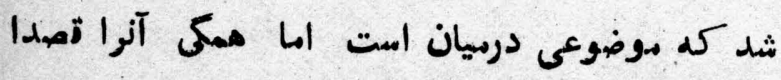

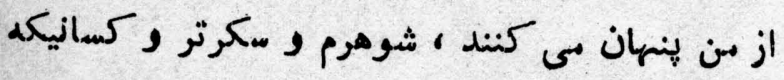

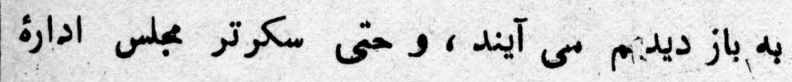

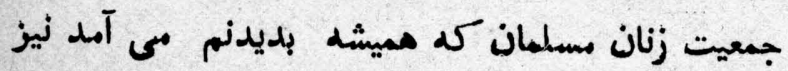

دستى اين جوانان برادر شهيد عبدالفتاح عبده اسماعيل قرار داشت ، و جون آن اخبار (طرح توطئه قتل از جانب بوليس سرى ناصر) برايم رسيد از وراز

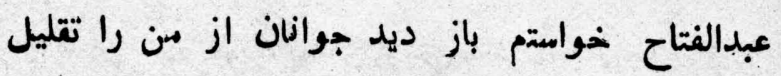

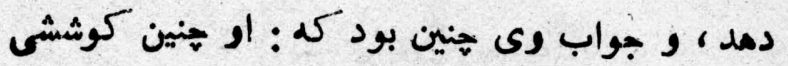

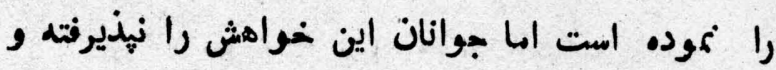

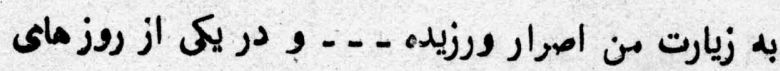
بعدى سكرتر ادارى "كروه زنان مسلمانه" در خاليكد دوسية اوراقى را بدست داشت ، بديدئ آمد و آبن.

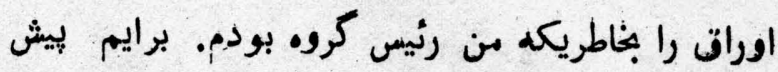

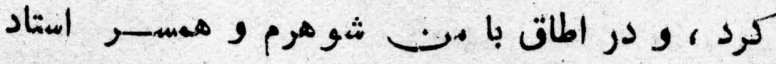

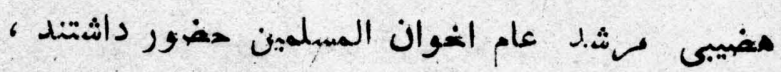

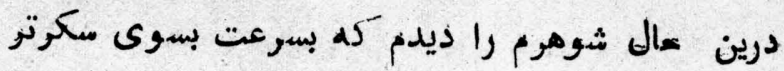

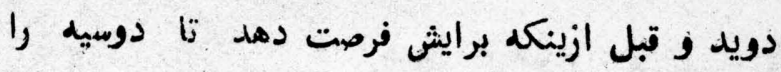

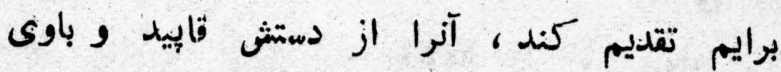

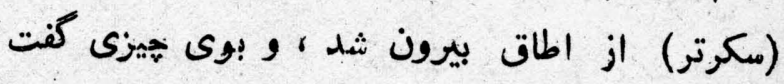

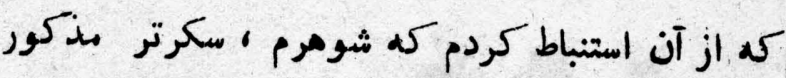

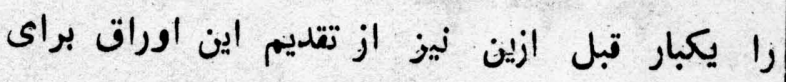

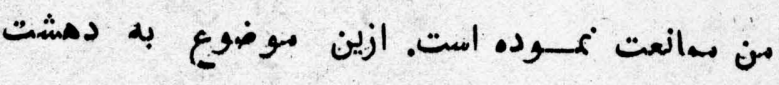

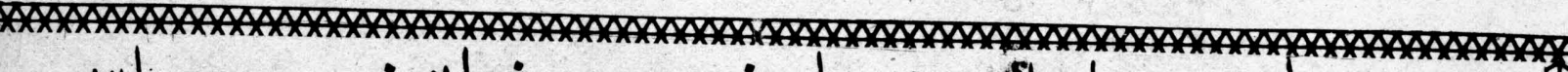
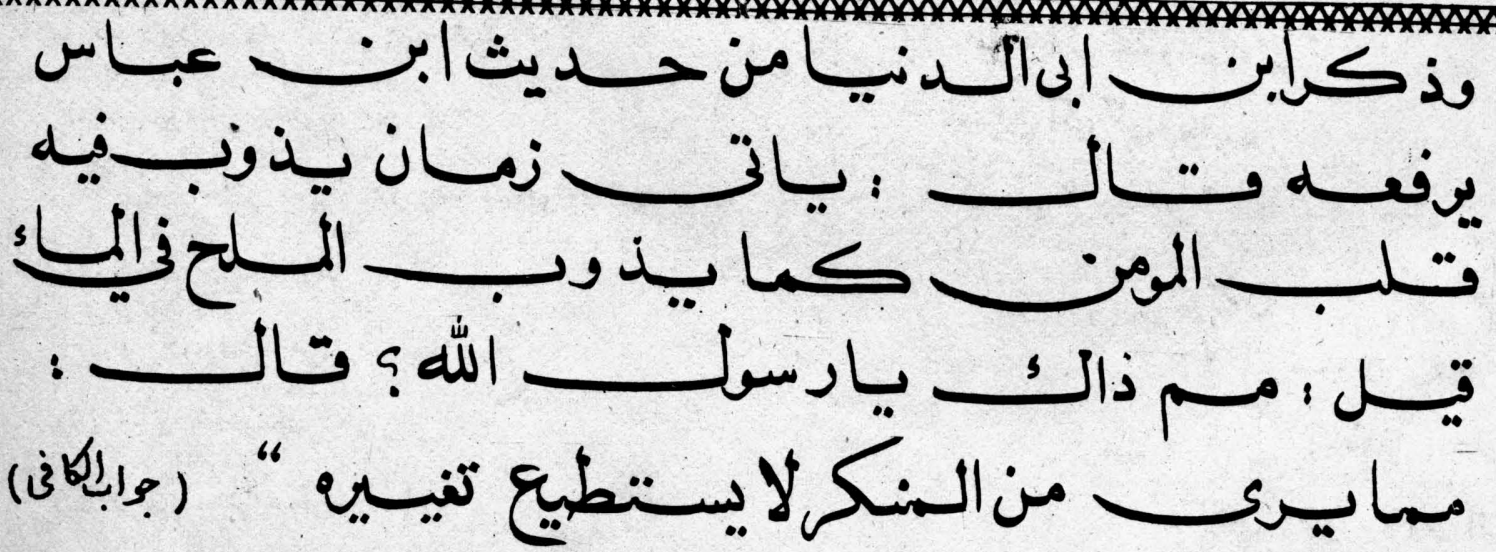

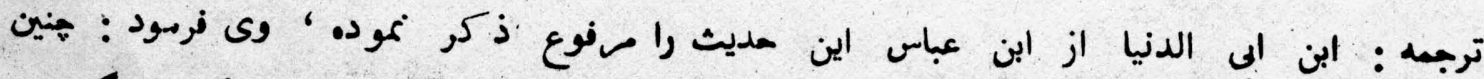

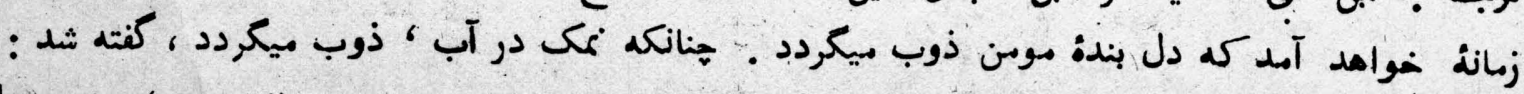

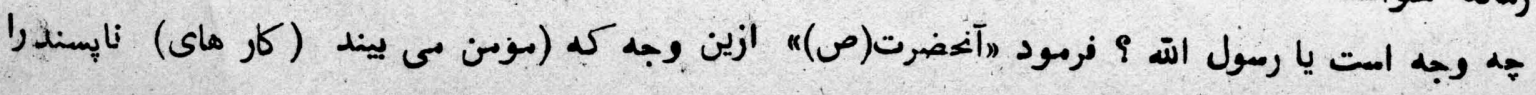
ولى نمى تواند كد آنرا تغيير دهد. 


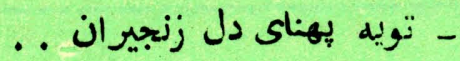

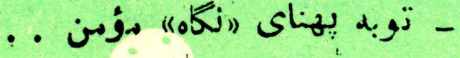

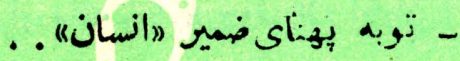

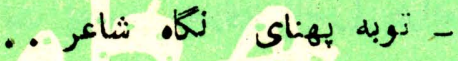

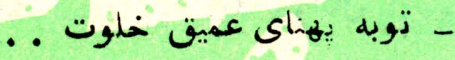

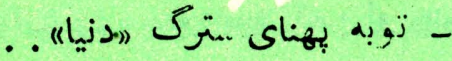

- توبه بهناي "وجودم، غمها . .

- - خوهر "(رمز)" نهانى ، آرى .

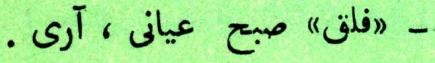

- مهرة ادرد زمانى ، آرى .

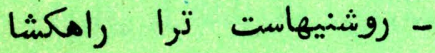

-

تا عبور از دل تاريخ "جفاله . .

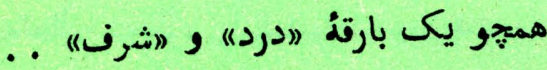

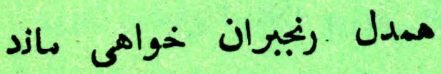

" اهمرة)" درد كشانخواهى ماند

تاجهانست "جوان خواهى ماند

$$
\begin{aligned}
& \text { YYM } \\
& \text { " . }
\end{aligned}
$$

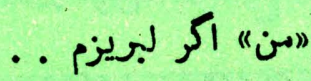

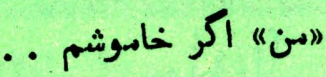

$$
\begin{aligned}
& \text { " . }
\end{aligned}
$$

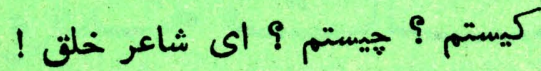

- مزرع سوخته ابميدم ..

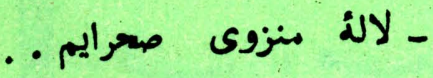

ـ طيث رنبكش دنيايم . .

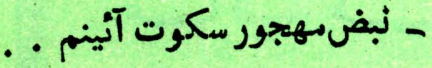

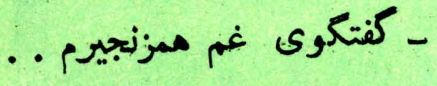

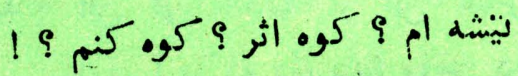

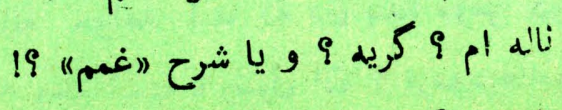

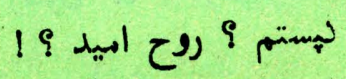

\section{وارث زلنجيه}

درد دل شاعرانة با هايون شاعر درد مند تارير تهايخ

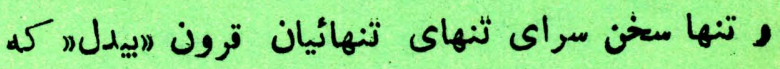

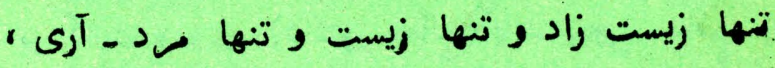

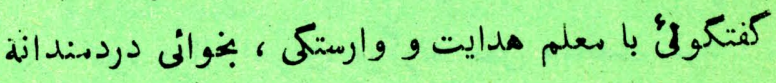

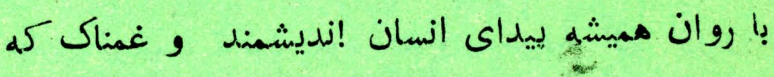

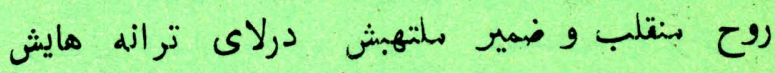

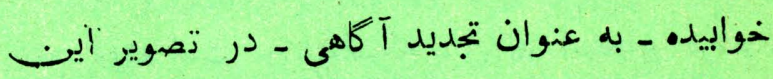

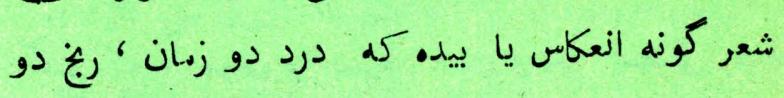

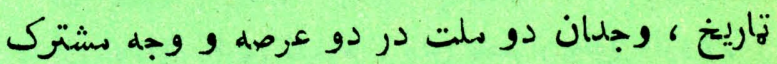

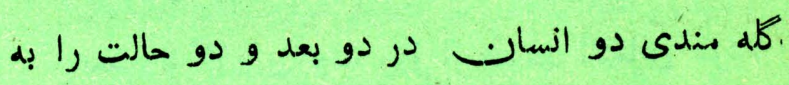
نمايش بيكذارد . .

(وما توفيقى الا بالة)

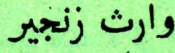

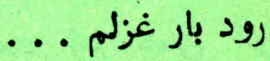

رود بار غزل تنهائي ...

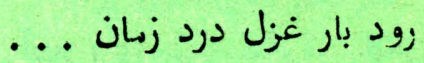

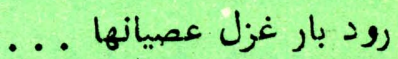

رود بار غزل خششم و خروش . . .

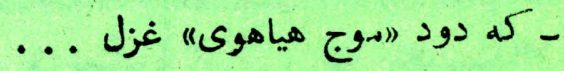

در سرا يردة" "إيدائي" من . .

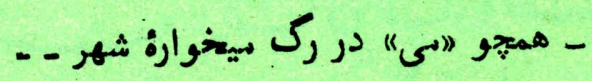

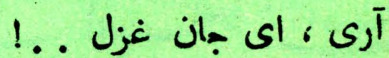

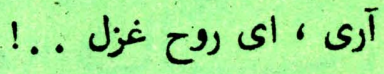

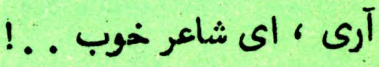

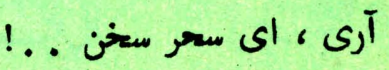

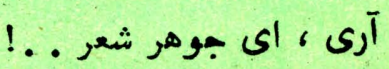

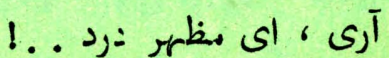

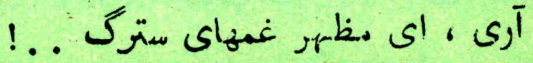

- توبه يهنائدل درد كشان ـ . . 


\section{XYK \\ : وكنون اي همدم ...

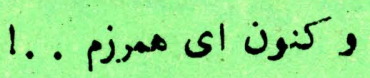

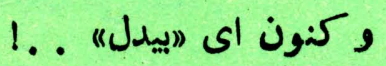

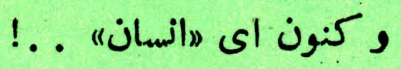

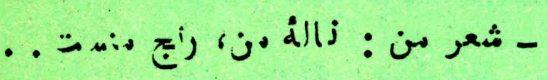

-

انطرابيم وشكستيم و رسوييم وهلكاك

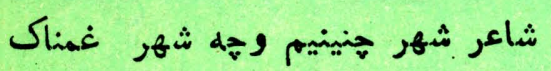

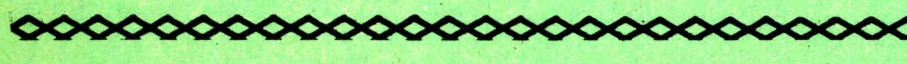

" نازولى يتيمان

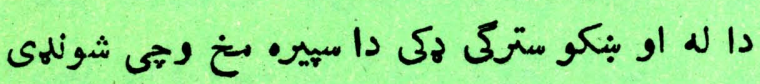

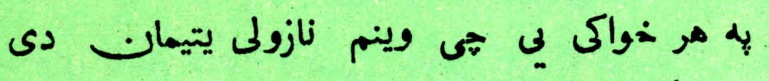

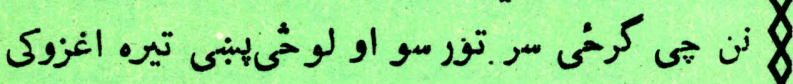

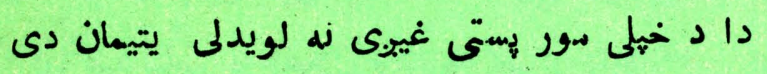

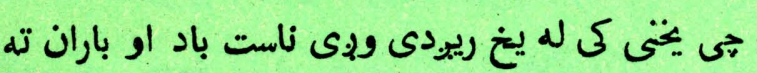

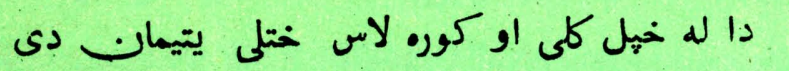
تورو شهو كى يهى له خو به كنكس كيج كإيى آهو نه

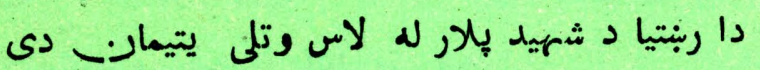

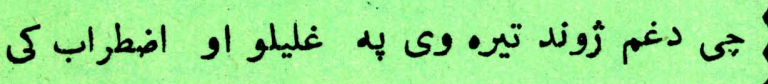

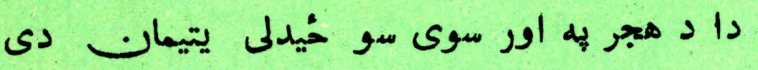

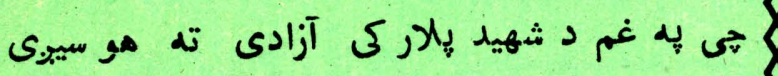

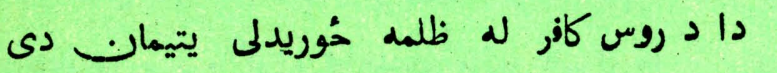

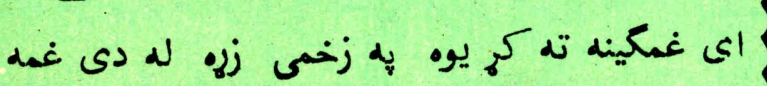

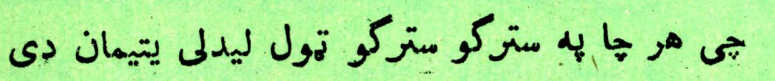

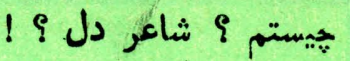
تو بكو ! نهم زمان 19

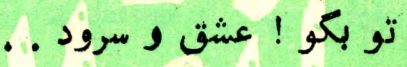
.. ! $91 \%$ व

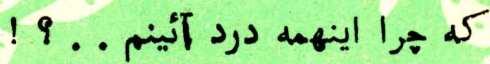

و

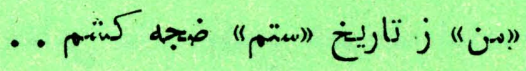

"

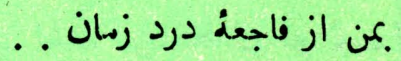

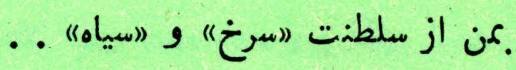

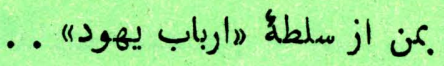

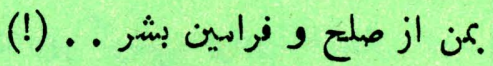

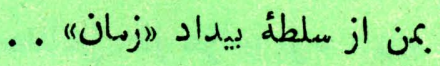

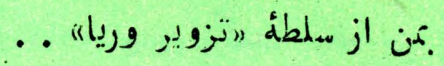

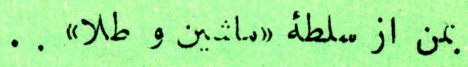

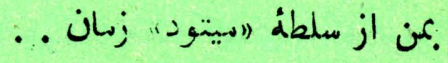

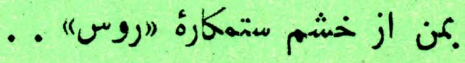

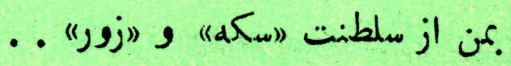
يمن از سلطنت جمعى لمن "ظلم" . .

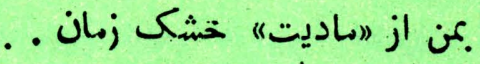

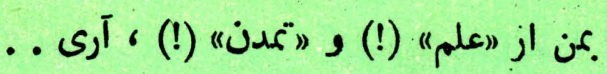
. كمن از جهل ابو جهلى و فقر . .

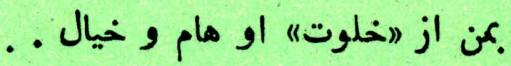
كمن از ضاف "درون" و " "بيرونه" . . . . بمن از فقر شناسائى "خوده" . .

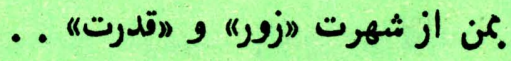
كمن از "دلقى" و "ترس" و و "طمعع" . . .

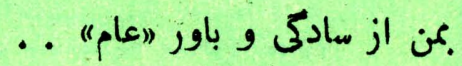

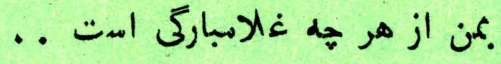

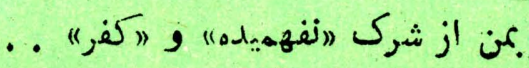

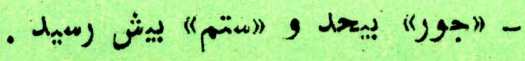

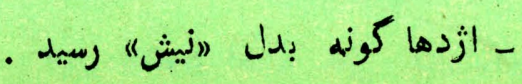




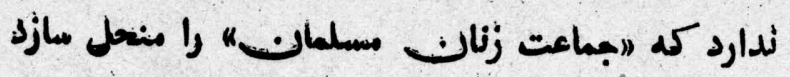

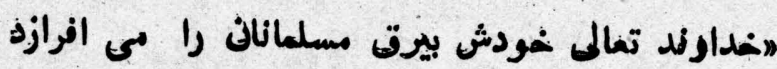

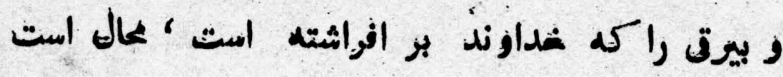
بشر سرنكونث سازدها.

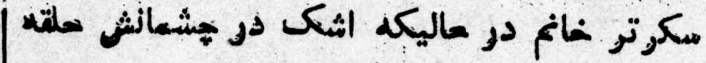

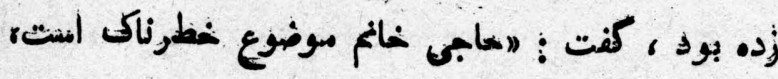

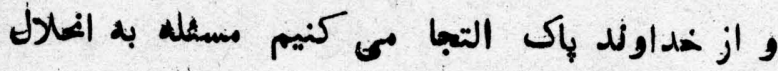

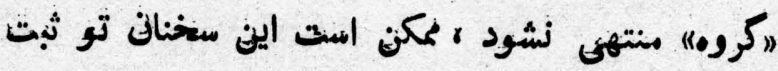

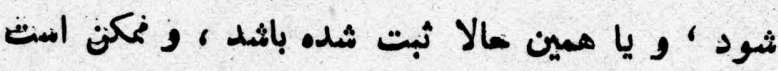

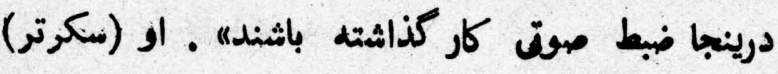
اين كلمات را بعهورت زير كوشى بزايم الظهار نمود

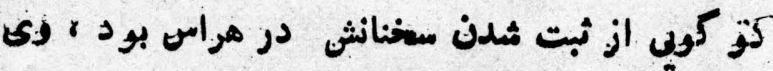

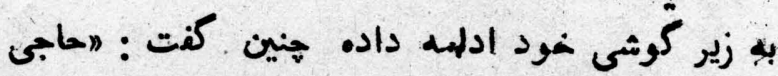

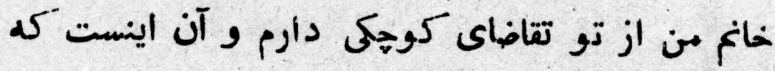

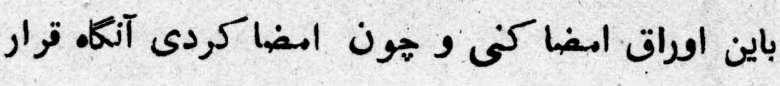
انحلال لغو ميشوده" .

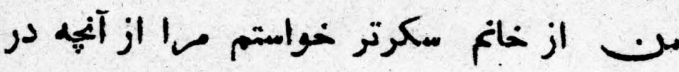

اورات مورد نظر موجود امتت مطلع سازد و حينيكه

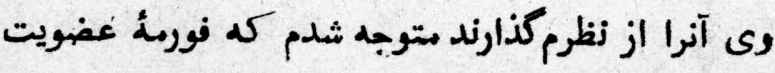

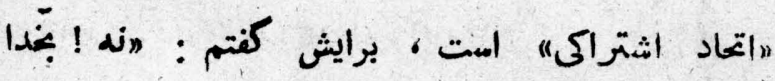

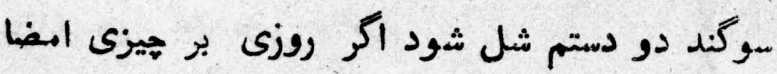

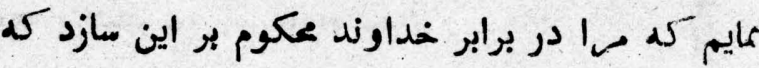
هكومت جهال عبدالناصر, طاغوت قاتل عبدالقادر عوده

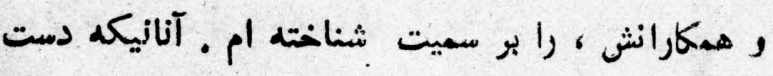

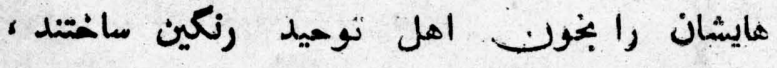

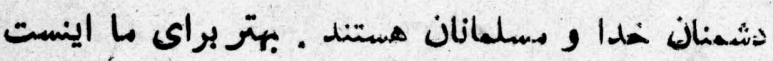
كه مكز عمومى "زنان هسلمانه منحل شودد". رى مرم را بوسيد و با كريد كفت : آيا اطمينان

دارى كله من ذختر توام

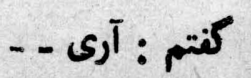

كنت : اين موضوع قضيه قتل عبدالتادر عوده.
طورى رفتار ميكرد كد از جواب مالى بـ ريطث به

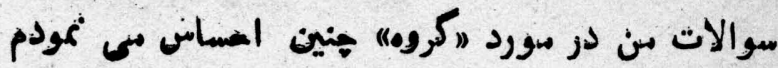

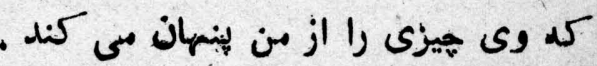

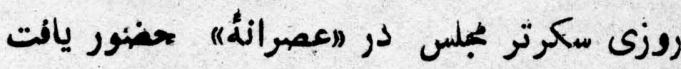
و همه شجاعت خود را بمع كرد تا در حضور شوهرم

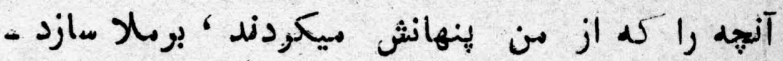

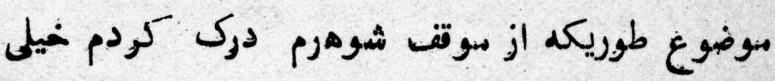

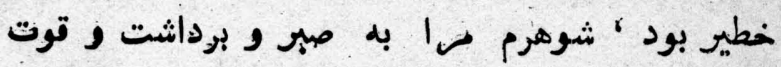

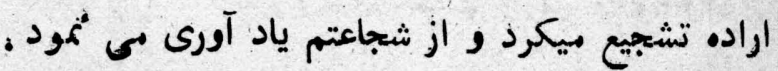

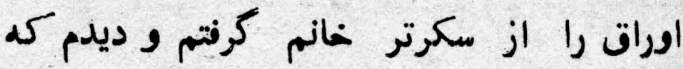
هاوى دستور انحلال "هركز عمونى كزوه زنان منسلمان"

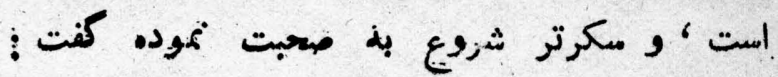
أطبكاًحأجى خانم تأثير موضوع نسبت بشمها خيلى شديد استه من كثتم "الحمد له ، ولى مكومت حق ند ندارد

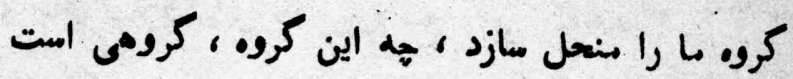
اسلاسى" وى باسغ داد : "كسىى ياراى اين را ندارد

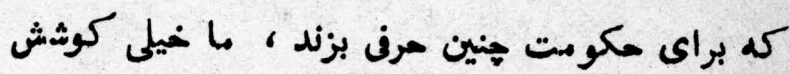

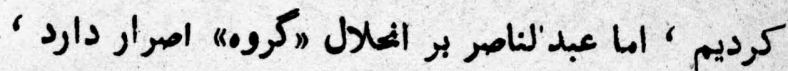

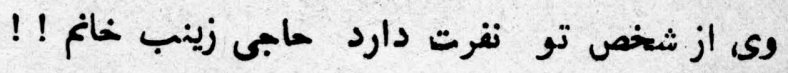

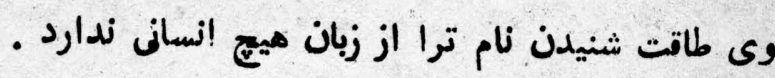

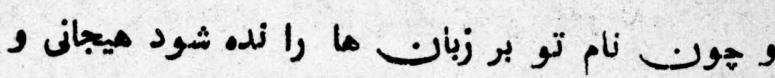

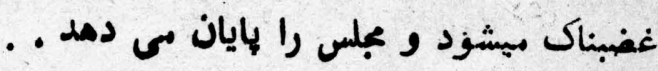

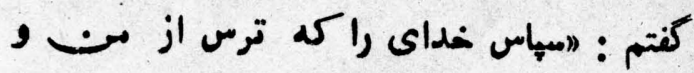

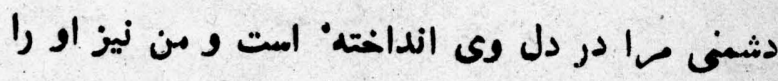

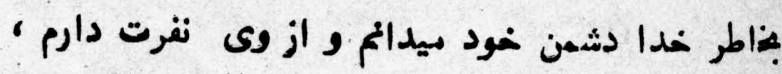

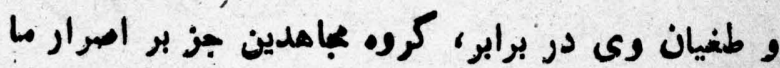

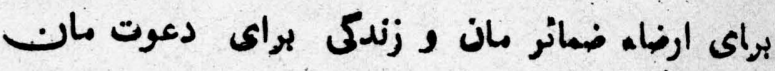

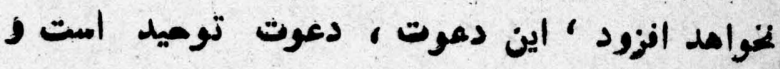

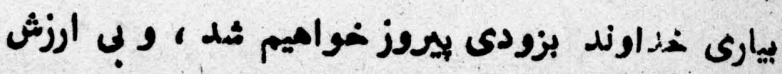

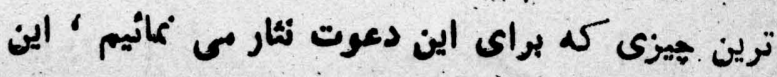
است كل در راه آن به شهادت يوميم م عبدالناضر مست 
ولايت : قاهر.

اين كارت از طريت بوسته برايم رسيد و با آنــ بندى نيز بود كم ثابت ميساخت بن حتى العضويت

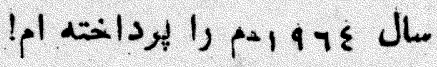
خندة تلخى بهال "مصري" كل "نا اين سرحد بد بديتى كشانيدة شده است نكودم و ايابى را بيادآوردم

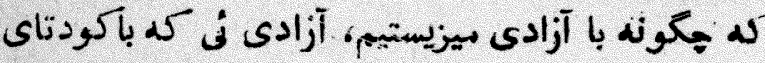

$$
\text { نظابى شال نفرينش كردزده . }
$$

بعد از تكميل معالجه در شفاخانه به منزل باز كشتم و مهزمان با آن متواتر از طرف اتحاد سوسيالزم يا اتحاد اشتراكى دعوت نامه هابي برايم ميوبيد كه در

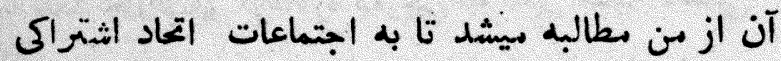

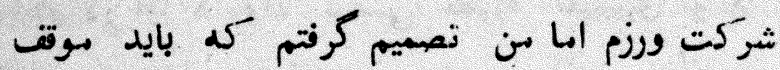
منفى اتخاذ نمايم . منرم

هند روز بعد دكتور معالجم اجازة خروج از خانه و ليشبود كار هاى مركزعموسى زنان مسلمان

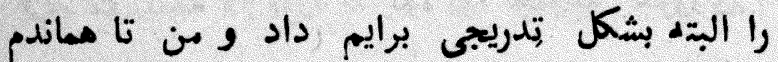
باعصا راه مى رفتم .

صبع يكى از روز ها كل در مسكز عمومى زنار. دسلمان حضور داثتم · تيليفون زنك زد و سكرتر از هن خواست باكسى كله از اتحاد اشتراكى ميخواهد بال. من هرف بزند صحبت نمايم ، كوثى را برداثتم و كفتم : "السلام عليكم" از آنسو شيخصى كم تيليفون

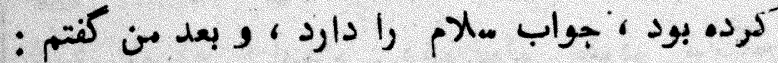

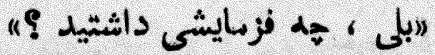

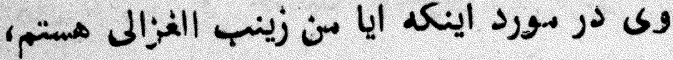
ميرسيد و هون جواب مثبت شنيد ، كفت : (اينجا مقر اتحاد اشتراكى است و ما منتظر آنيم كد انشاه الته

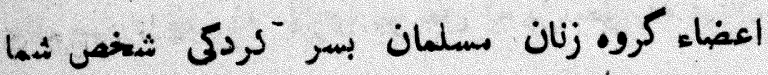

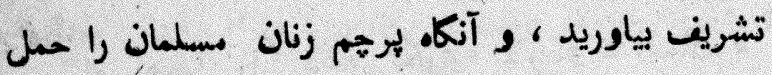

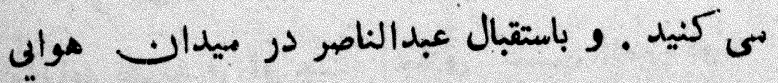

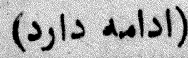
و - - - ) را كنلر بكذار --

كتتم : خوب - - كنار مى كذارم ، ولى هر كز

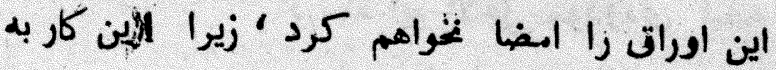

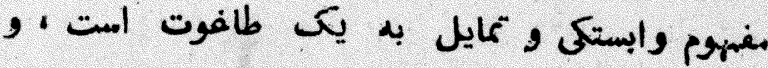

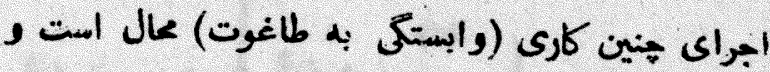

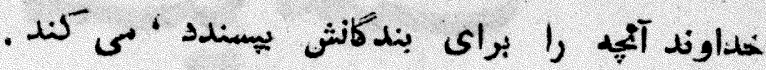

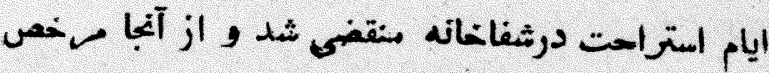

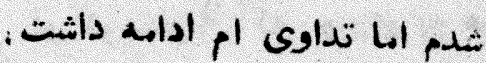

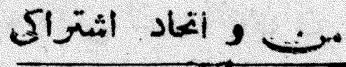

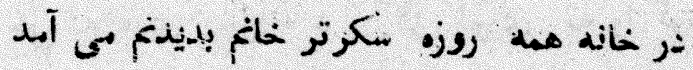

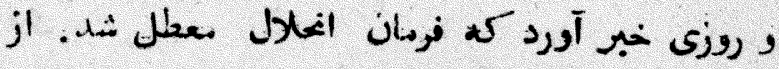

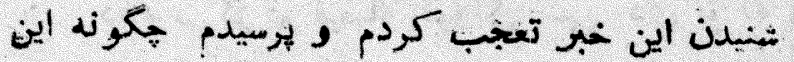

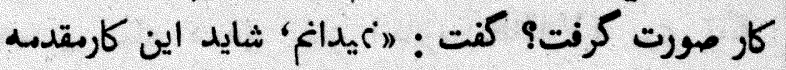
و فتع بابى باشد در جهت قايم ساختن ارتباط باتوه.

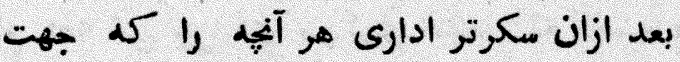

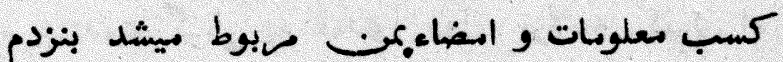
بى آورد و من نيز اجراى امور مـوكز عمومى زنان

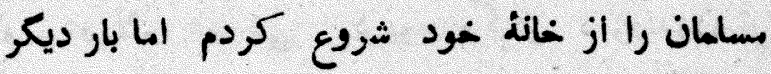

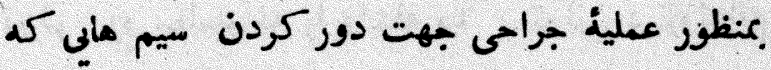

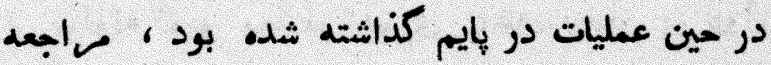

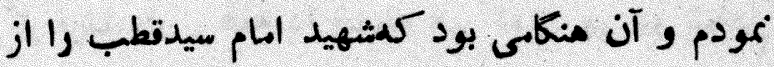

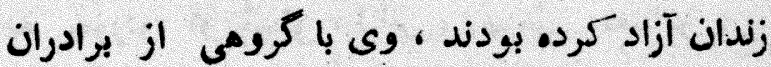

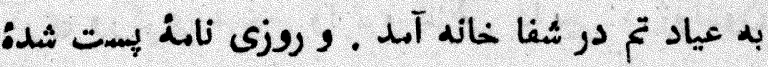
رأ كل عبارت بود از كار تى كم در آن عبارات ذيل نوشته شده بود ، دريافت داشتم عبارات كارت " هين بود : "اتحاد سوسيالزم عرنى" آزادى - سوسيالزم - وحدت

أسم و شهرت : زينب الغزاللى الجبيلى سشهور به زينب الغزالى وظيفه يا كار ادارى : رئيسه مهركز

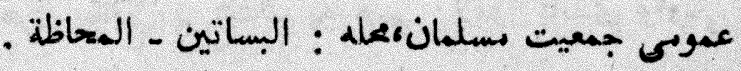
ولسوالى : مصر جديد 


\section{د محمد اجان "حقهاله زيإي.}

\section{د سيد ابو الاعلى مودودى كيلنه}

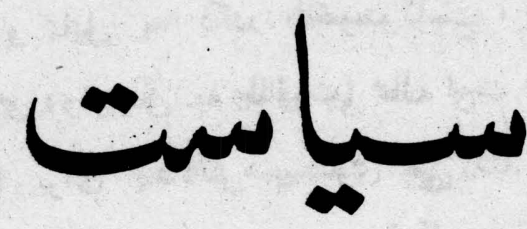

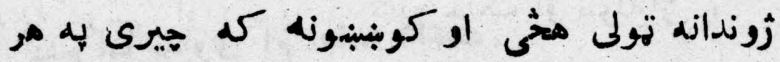

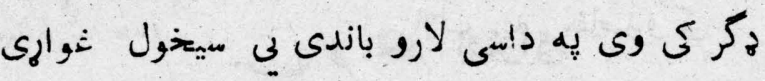

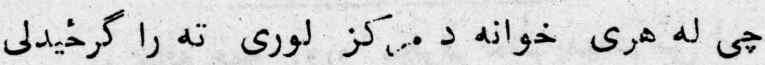
وى

دغه مكز يو فيصله كوونكى شى دى نو له

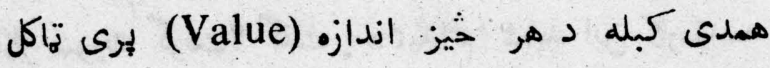

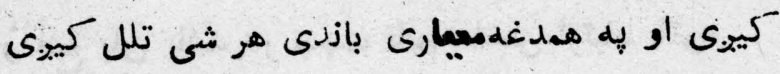

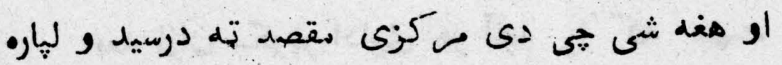

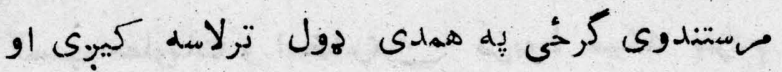

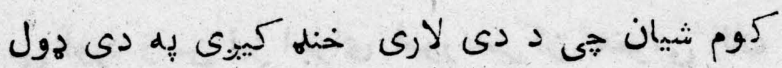

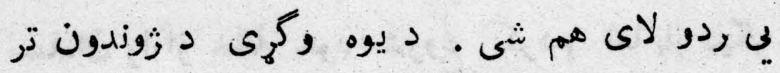

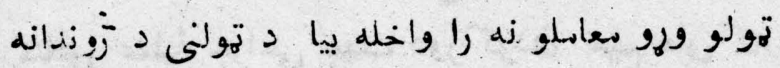
تر تولونه لويو معاملو يورى دغه ثمعيار يو رول

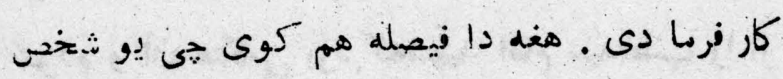

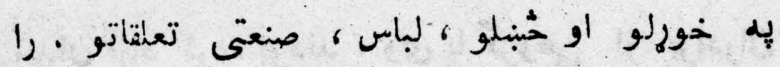

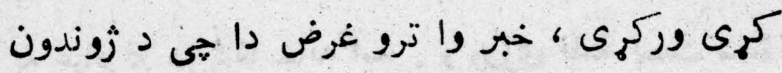

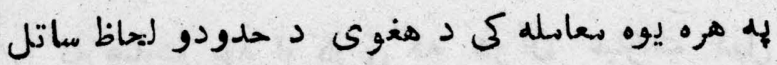

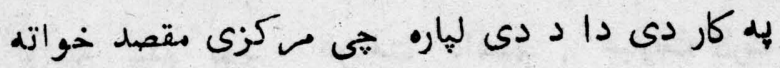

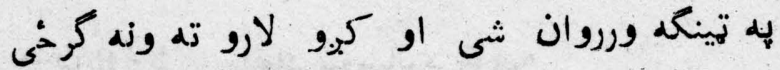

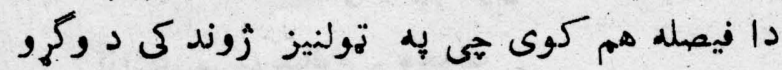

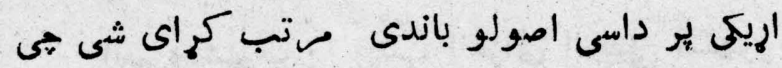

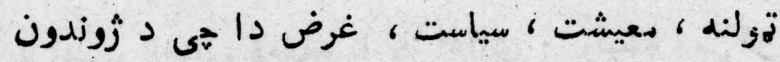

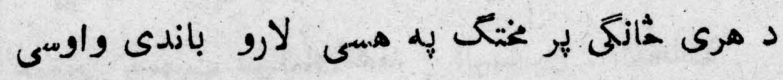

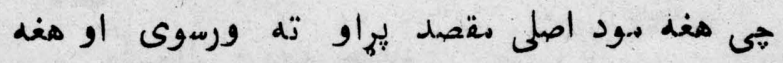

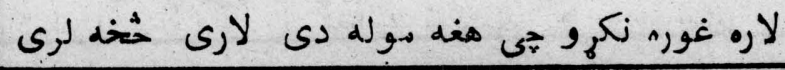

\section{كيرى كنى لبسى}
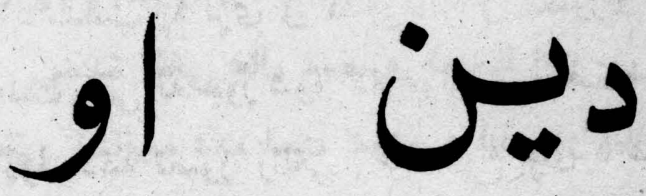

مذهب او تهذنب ! Attitude of (اسلام د فكر يوه خانكرى لار لار

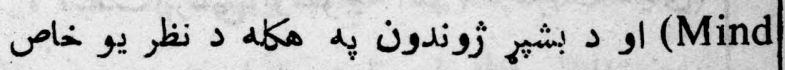

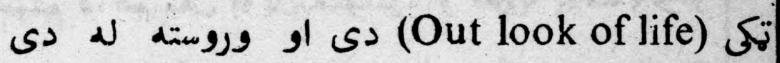

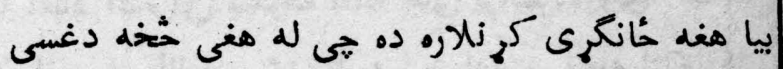
فكرى لار او د زوند دغسى نظريه تعينيبوى نو د

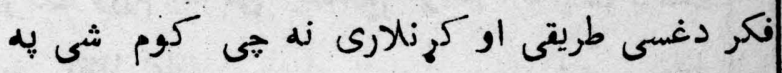

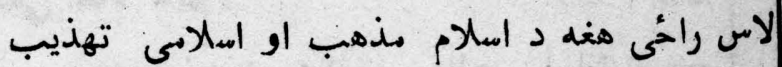
|دى بهلدى كى مذهب ، تهذيب او تمدن يو له بله

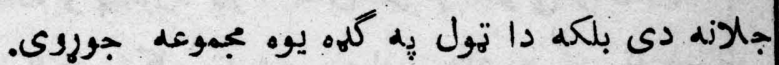

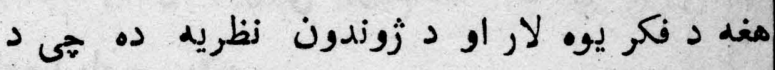

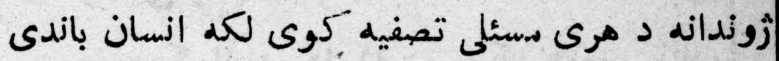

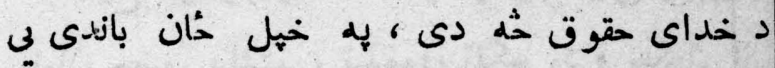

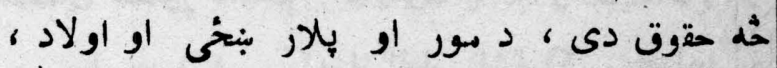

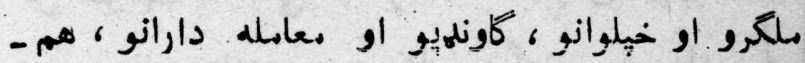

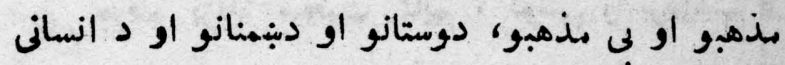

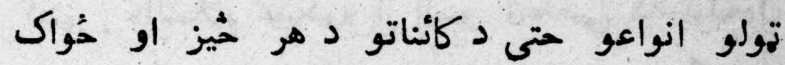

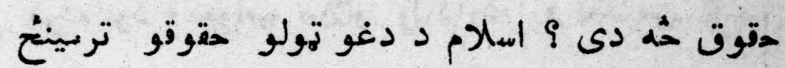
بشبي توازن او عدالت قايموى او د يوه شخضر د

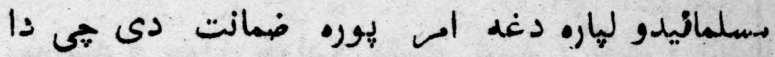

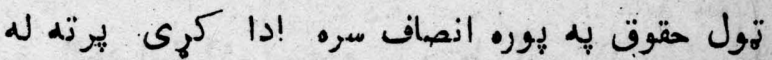

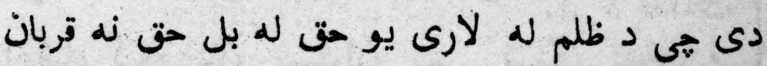

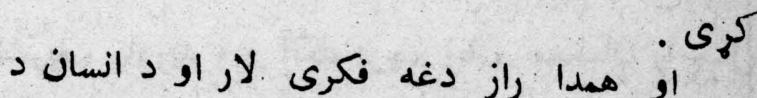

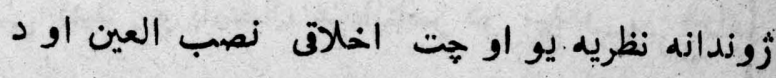

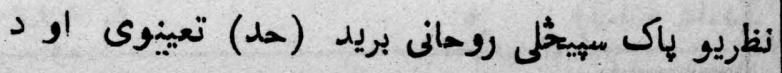


اريكله يرا كيي.ى او له هغو تهولو زله د ماشين.

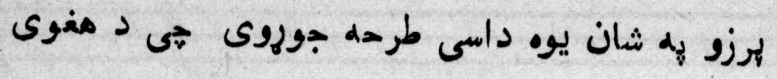
له مركت او تعاسل تله صرف يوه نتيجه راوخى .

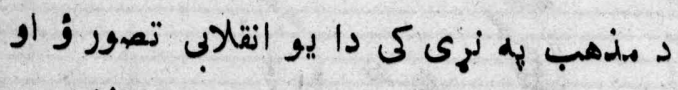

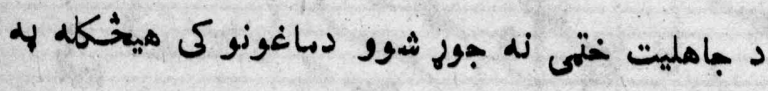

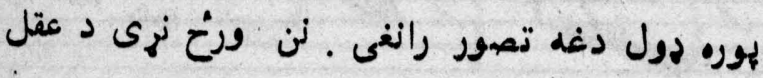

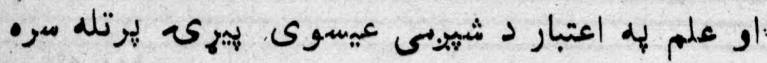

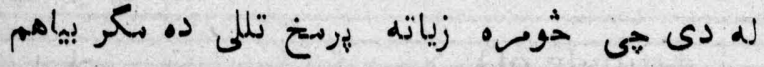
دومه قداهت ليرستى او ليوت إندى (تاريك خيالى) هو جوده ده هیى د ارويا يه سشهورو افاقى يوهنتونونو

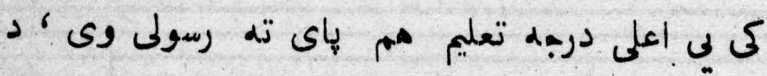

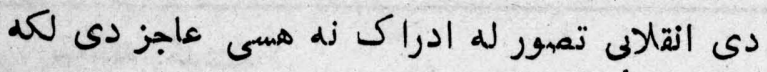

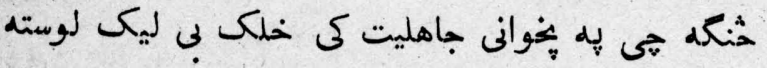

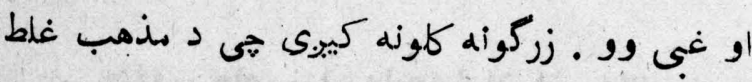

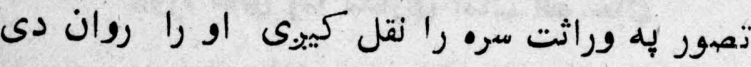

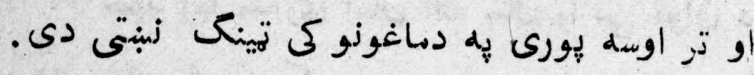
د عقلى تنقيد او علمى تحقيق خو راغورو تربيى خينى هم د هغوى د منزو غوتى خلاصى زله شوى الهي او د_خانقاؤ او جوماتونو يه تورو كوتو كى او سييوى

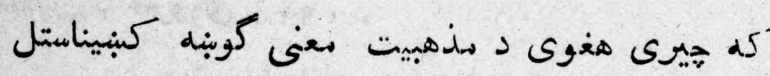

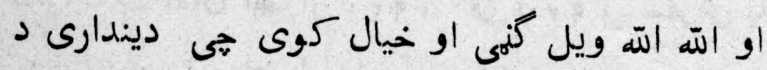

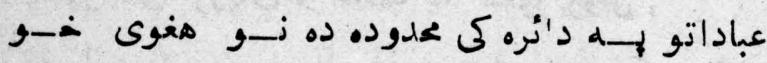

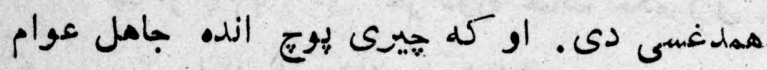
مذهب دباجى غمنولو ، حأن وملو او له غوانى خينى

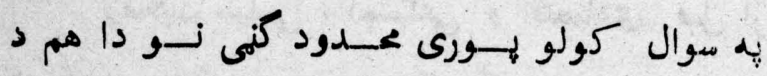

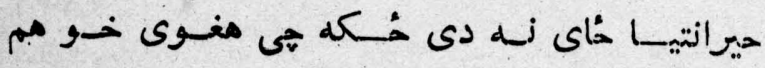

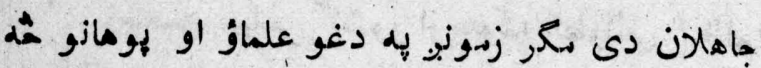

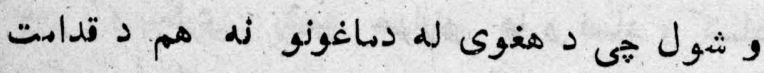

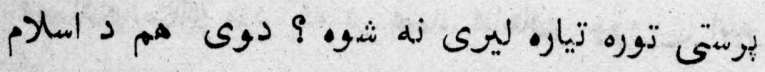

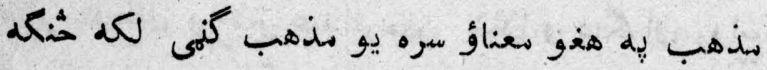

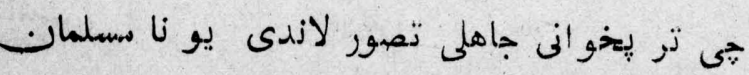

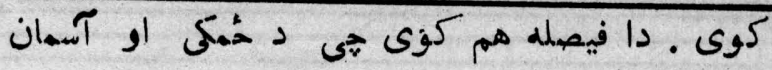
به قوتونو باندى النهان و بإوهول شى او كوم ثيزونه

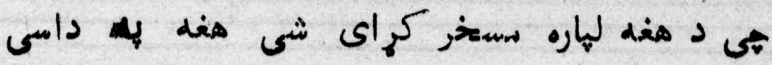

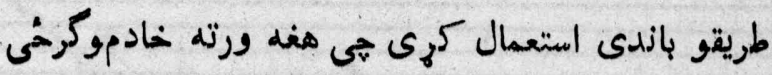

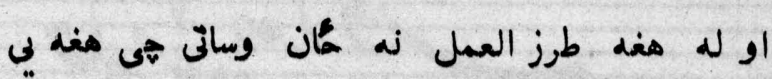

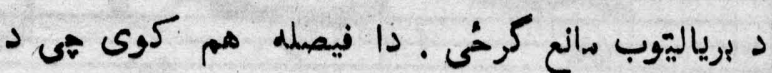
اسلاسى تولنى وكرى د غير اسلابسى تولنى له وركرو

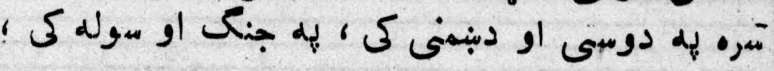

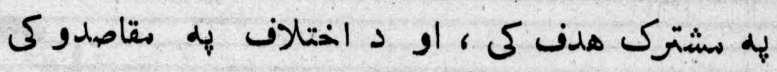

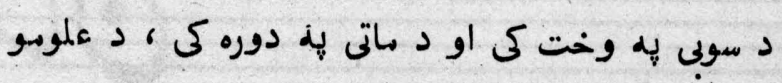
او فنوزو ليه حاصلولوكى او د تهذيب او تمدن يه

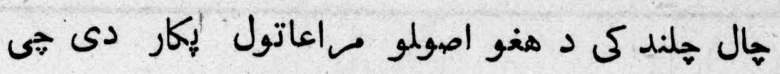

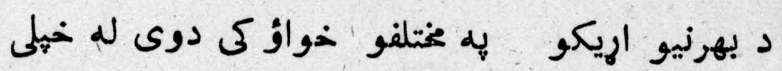
مقصودى لارى نه وانه روى بلمكه تر هغى اندازى لهو

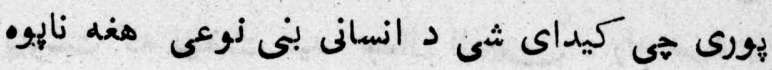

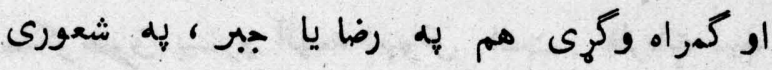
يا غير شعورى هول د هغd مقصد لهاره راوبولى هـى

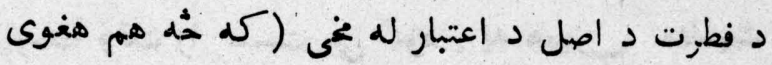

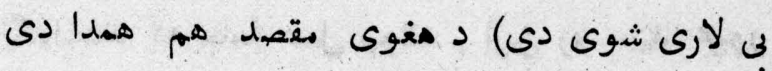

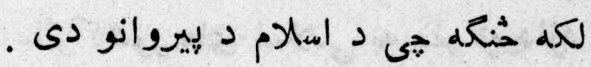

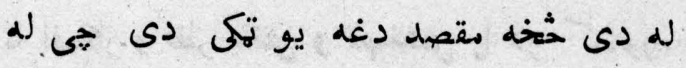

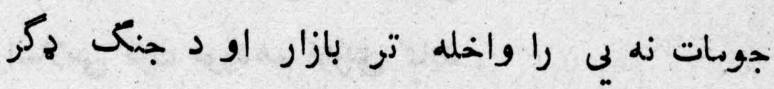

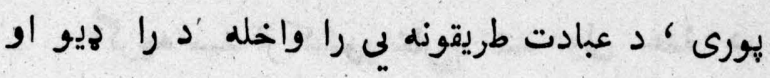

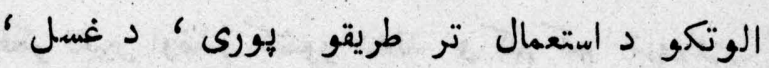

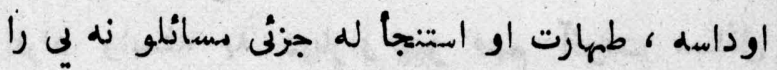
واخله ان ترلو يو تولنو ، معاشياتو ' سياسياتو او د

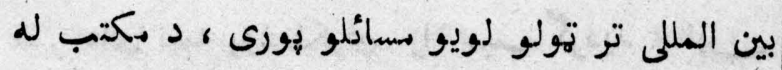

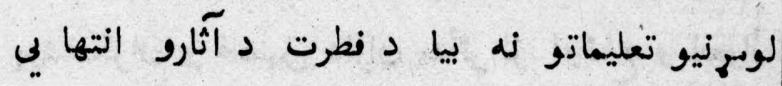
سشاهداتو او د طبعى قوانينو تر تولو لورو تمقيقاتو

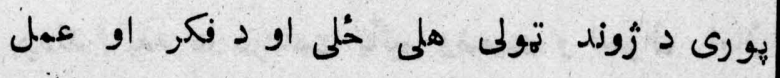

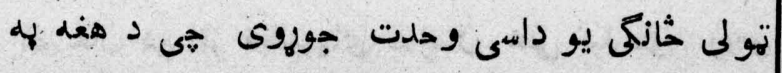
توكونو (اجزاؤ) كى يو هدفمن ترتيـب او يوه ارادى 


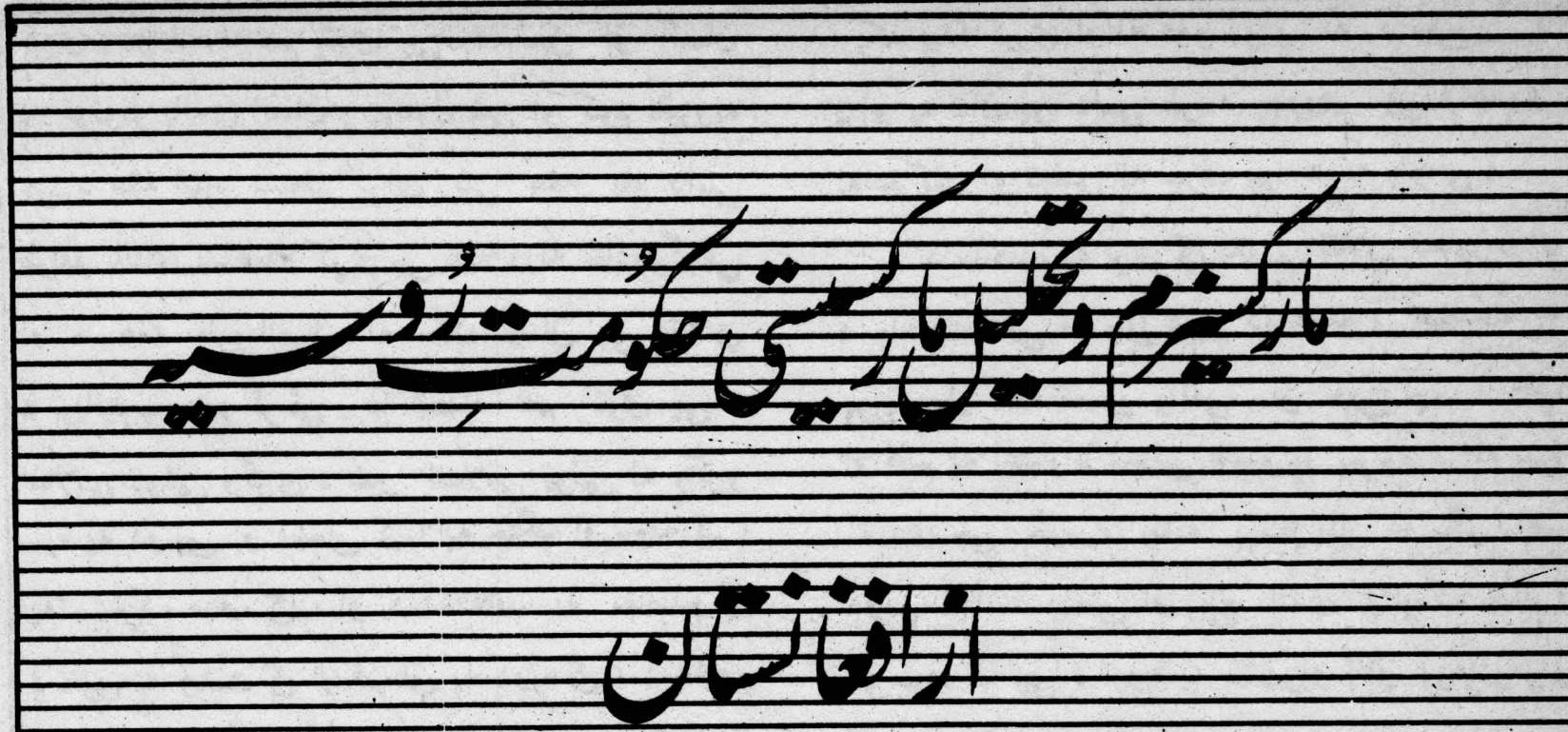

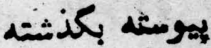

قرن زوزدهم در بعضى از كشور هاى اسلامى بوقوع

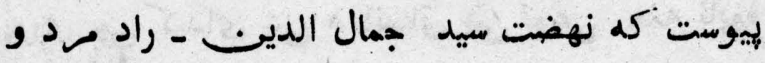
مفكر فور بيشرو آنهمه نهوض است . نظريات سيد در كشور رتضمن تغيير بنيادى بود و بنيان مكلم خود

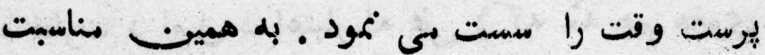

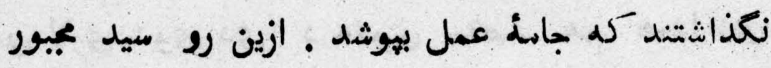
جرديد كله به سائر كشور هاى اسلامى به مفر بيردازد تا افسكز و زنظر ياتش و زمغتش را در كشور هـاى

$$
\text { اسلامى قرن زوزدهم ترززئق نمايد . }
$$

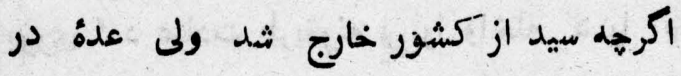

فكور تغيير اوضاع كشثور شدند وكم كم درميالن افراد وابسته به دوبار و هيز فهم آنوقت هـائل

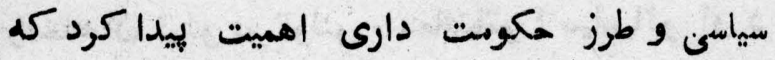

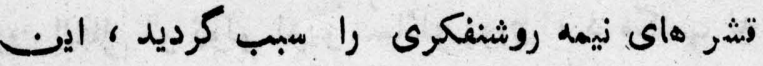
روشنفكران و تمصهيل داران متاثي از اوضاع و احوال و رويداد هاى كشثور هالى از قبيل تركيه وغير. بودزله ـ بعد ها در.تحت تأثير وضعيت و احوال امان الهه خان در اثو فعاليتهاى مازمان مغنى تبليغاتى روس

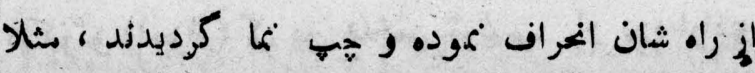

\section{دورو ماى زما مهارى امان الته غان}

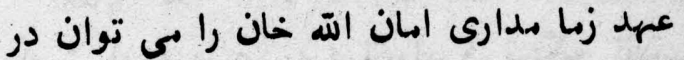

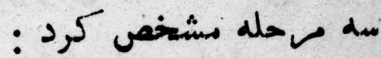

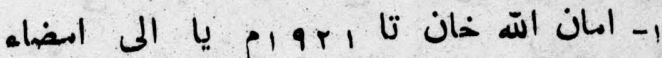

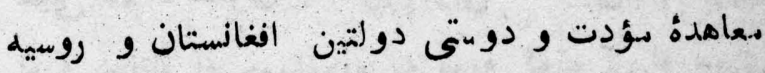
- 1

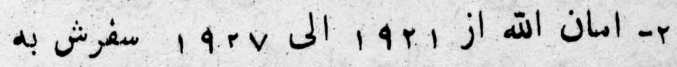
كشور هاى اروياى و خاصتاً به كششور روس .

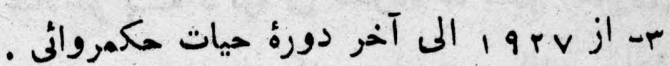

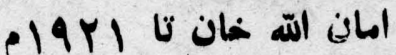

رضغيت سياسى ، اجتملعى و اقتصادى قبل از I9r| وضعيت سياسى كشور از ملوك الطوائفى ' ظلمه جبر · و بيكارى · رشوه خوارى ها و فساد و كساد

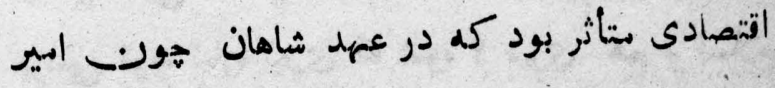
شير عليخان و امير عبدالرحمن خان و ديكران رواج داثت نهوض در قِّال مظالم شاهار. ـ و طاغوت در 
(بيكارى) براى مأمورين رسهى ظلم مأمورين و استثمار ذهقاذان خوردميشيد .

اجتماغ كشور مـذّب از طبقهُ فيودال و دهقان

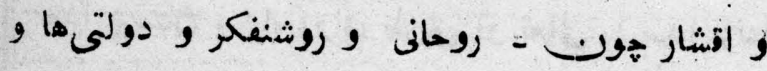

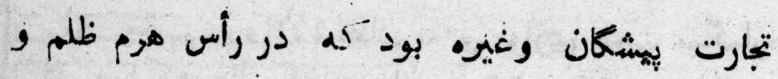

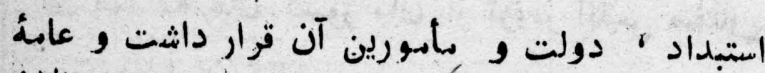

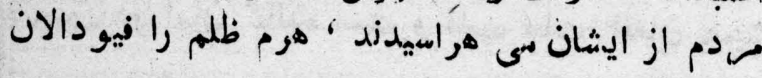

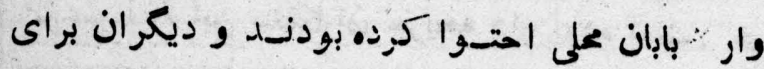

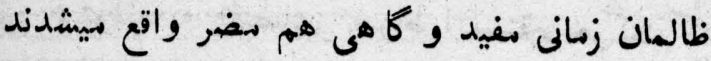

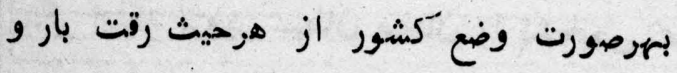

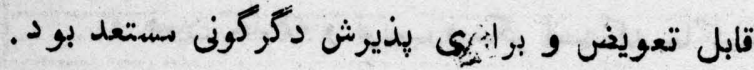

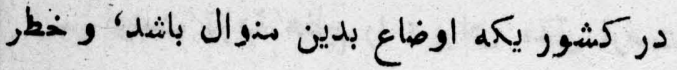

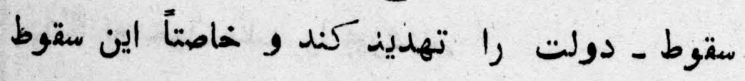
ناشى از وضع درهم و برهم اقتعادى باثــاه لاعمال

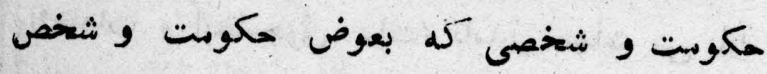

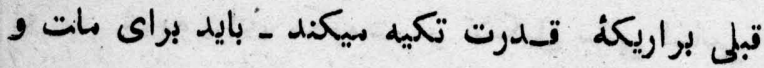
نيروهاى نهفته و كمين نشاتهه ايكه در صدد تجم و

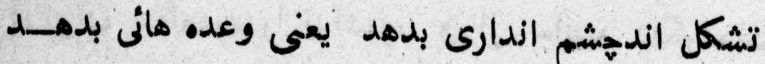

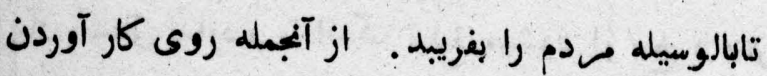
اصلاحاتيست كه بآن زيروهاى زهفة و در كمين نشته

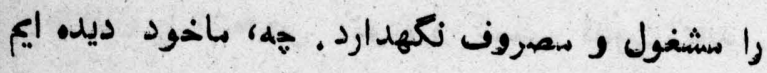
هنكايكه در نظامهاى بى نظم و بـ هدف' طرح نظم

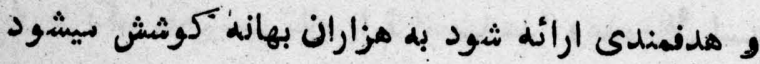

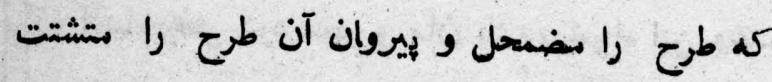
نمايند.

به مبطالعة تاريخ خصوصاً تاريخ افغانستان و على الخصوص در قروبن. اخير كه اوضاع و احوال

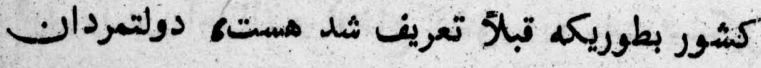

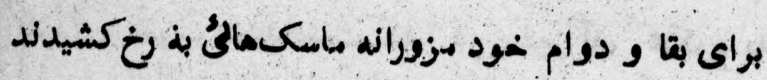
تاخود را مسدمى نشان دهند.

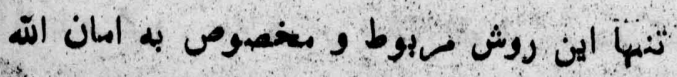
لبوده ' مستند عده ايكه به منكاسى در ثرايط نابودى
ترك آداب و رسوم سلى را ولو بِعنديده هم مى بوه

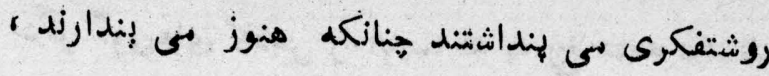

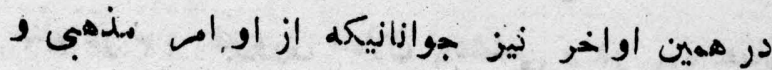

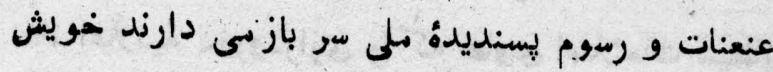

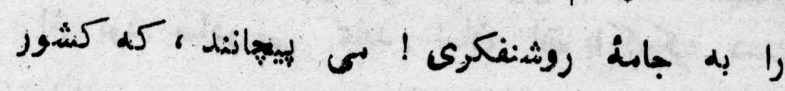
اكنون كريبان كي فرآورد هاى آنهاست،

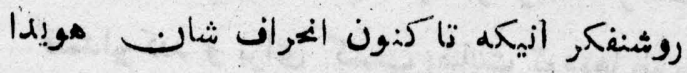
زبود نيز با دولت مخالفت بى ورزيدند و براى برانداختهن

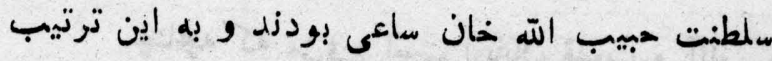

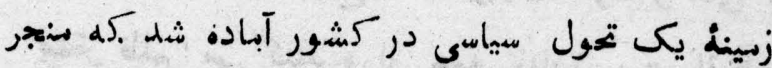

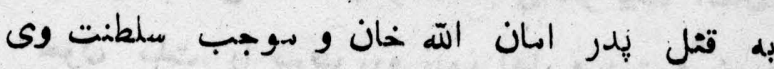
كرديد المان الهه خان بر اريكذ قدرت تكيه بى كنــــ

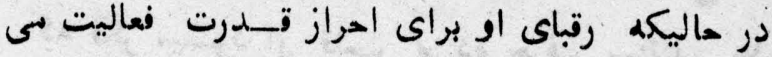

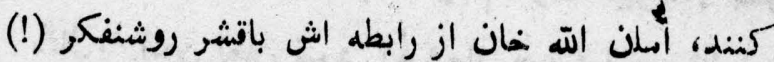

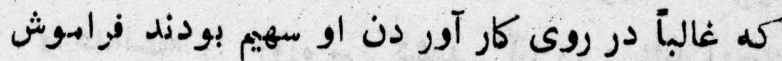
ثمى كند و دست به اصلاحات و ريفورم هائى مى زند.

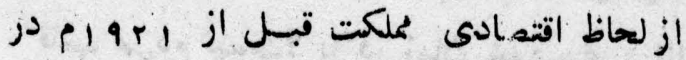

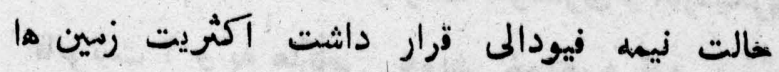

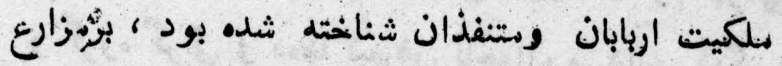

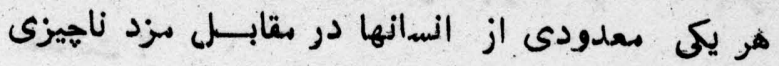
نيروى كار شان را به بصرف مى رسانيدند و و عدة مهم

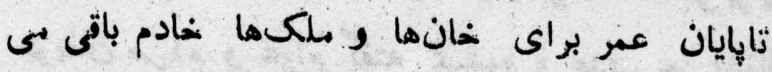
ماندند ، زراعت توسط وسائل قديمى و مروجه هورت بهائ

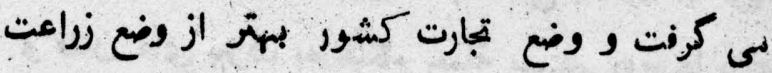

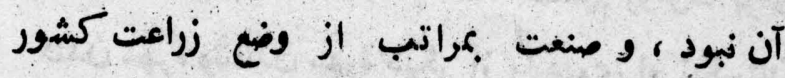

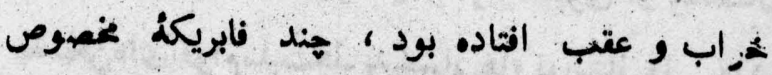

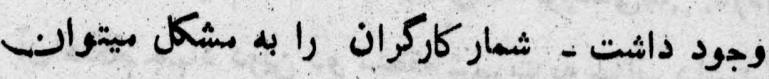

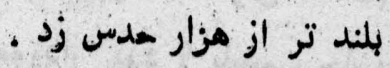

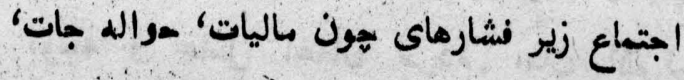
ظلم و تعدى ارباب و فيؤدال، "حدمات رايكاس. 


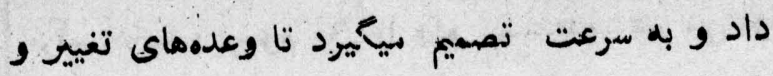

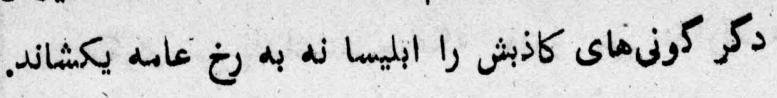

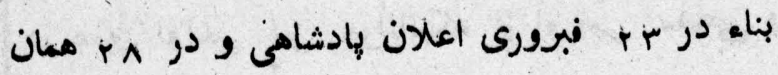

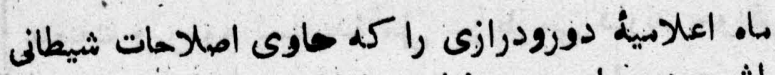

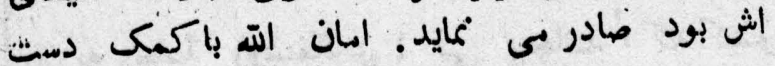

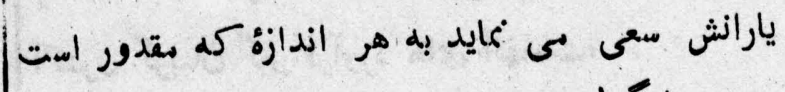

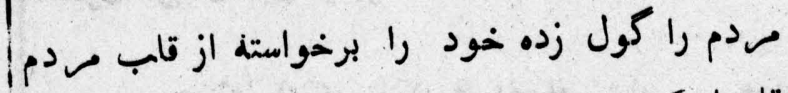

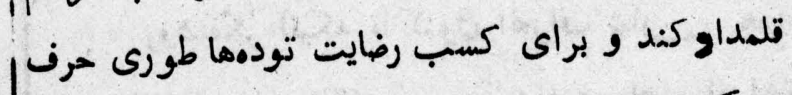
بزندكه تا ثهرة حق بجانب را دارا كردده.

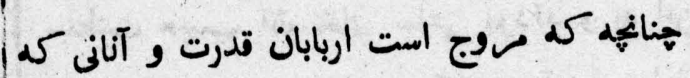

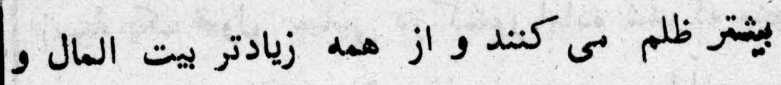
خون ملت را صرف زرو زيور امل و بيت و خويش ونس

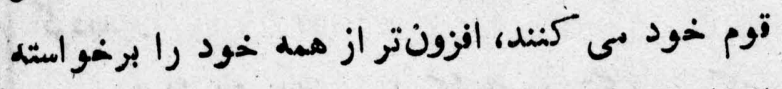

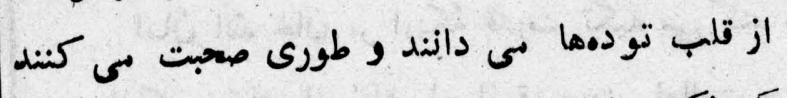

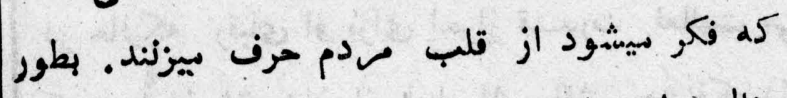

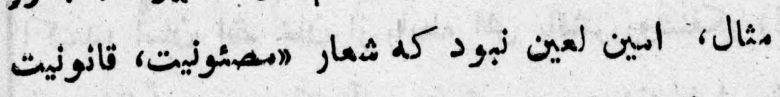

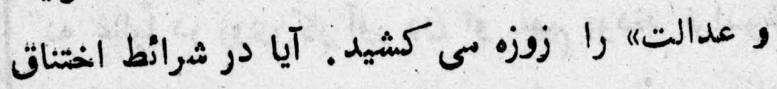

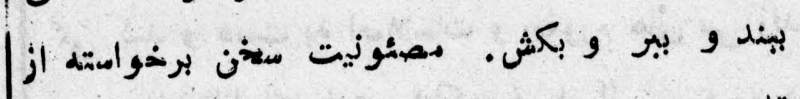

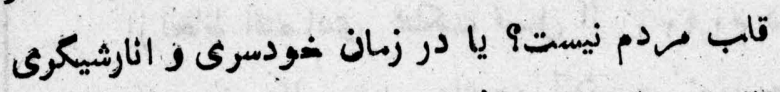

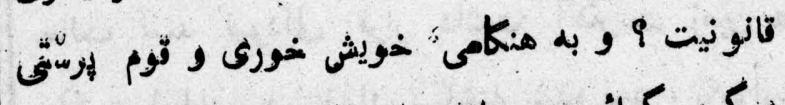

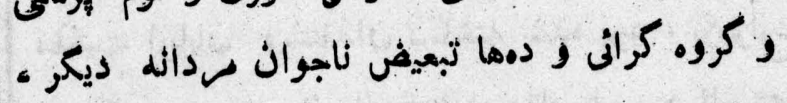

اينها همه سخغنان خوب و نيكواند، الماجز براى مريفتن مهدم و عوام كنته نميشود و هدف جز اغنال

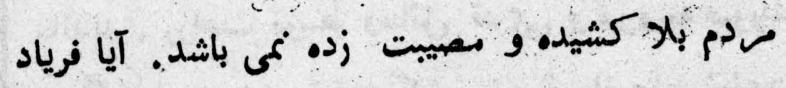

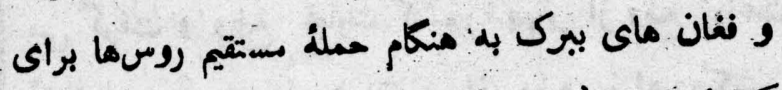

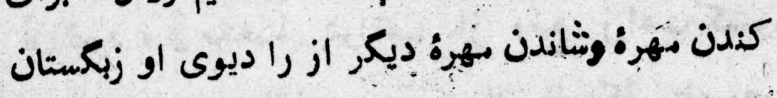

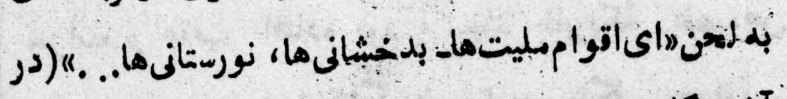

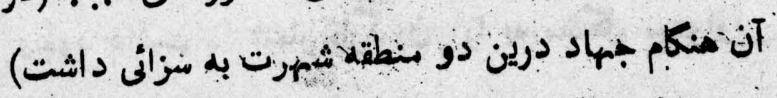

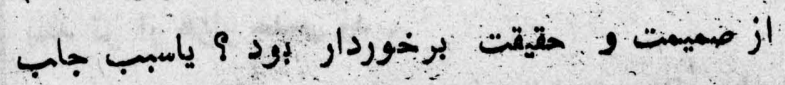

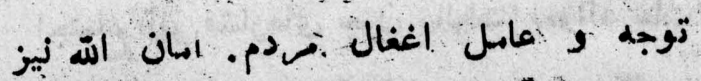
معبتمانقى كرد تا رضايت ملت را كسب مكايد بادعانيه
و سقوط ترار ميكيوثن إيش از آنكه بخدا(ج) و قرآر.

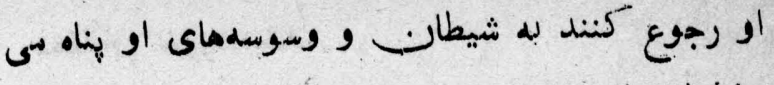

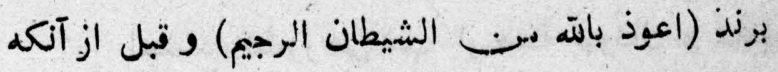

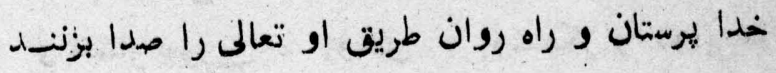

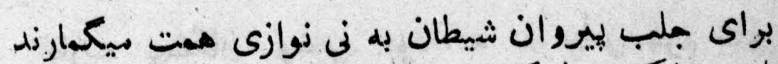

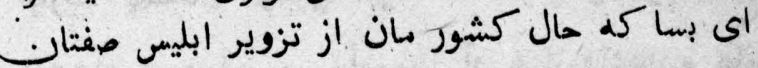

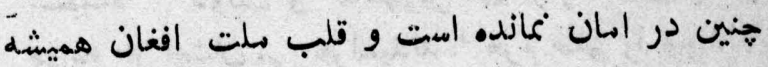

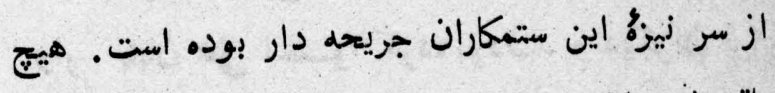

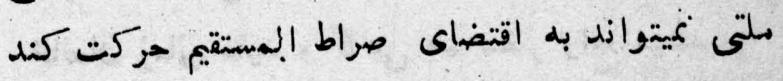
مكر أينكه تزوير شيطان صفتنان را تشخيص نمائده.

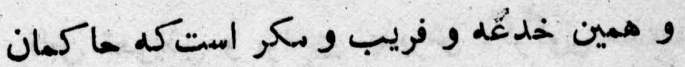
برسر نوشت تودة عظيم را ، براى مدتى فرصت ميد ميدهد

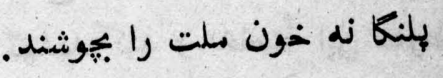
بايســــترتيب شخص و يا دولت از ساتور

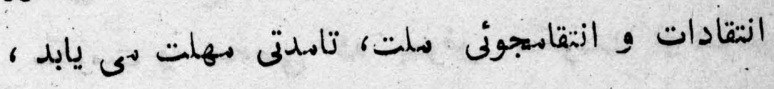
و اين شيوه براى حكو.ت نو تشكيل مشى اساسى و

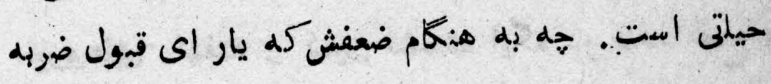

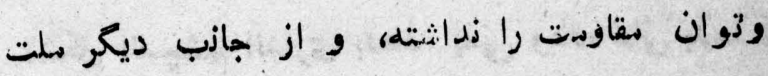

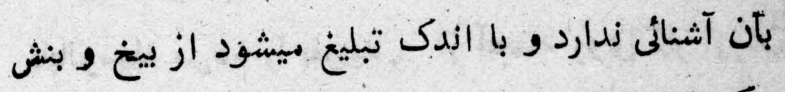

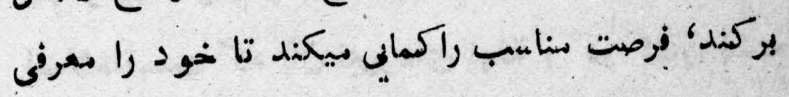

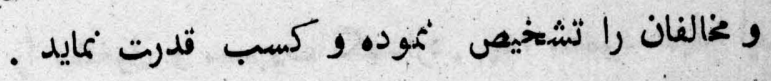

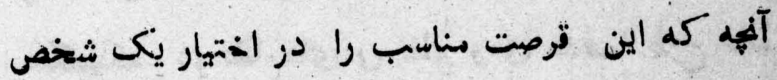

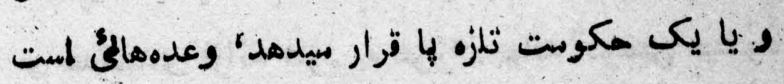
كم التيام بشث درد تحر و مان باثددا، خواه اين وعده.

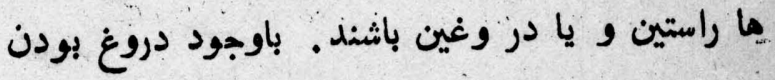
نيز عمرى دارد كه در طول آن ملت فريفة شود. امان اله با وقوف اين وضعيت، وعده ماى كاذب دركر

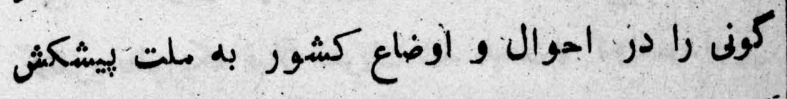

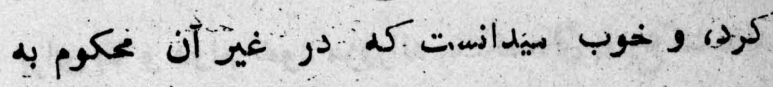
ستوط است به همين لحاظ فرياد دكر كونى و ريفورم

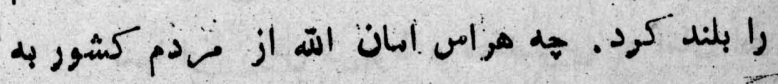

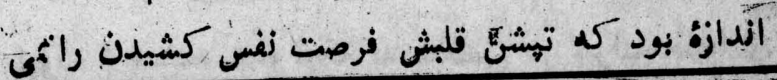


آنهج كه از وضعيت سياسى، اقتبطادى و اجتماعي كشور

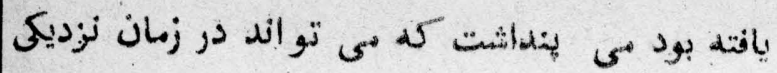

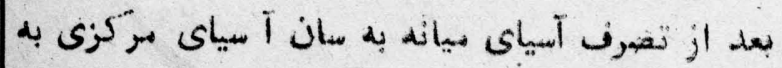

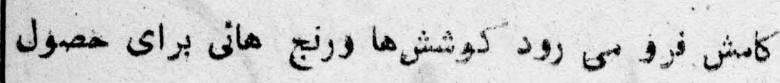

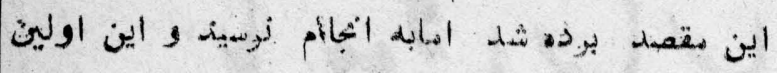

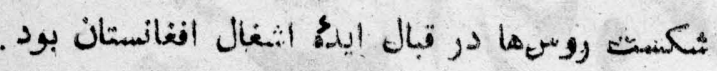

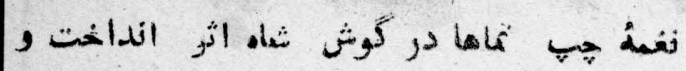

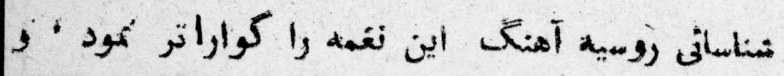

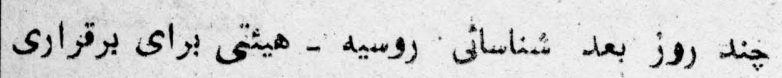

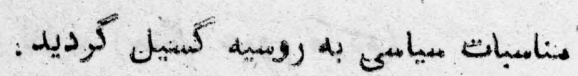

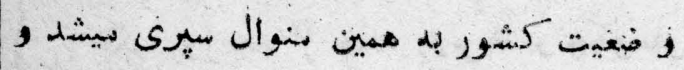
زوسية شوروى باهرانة ازين و ضعيت براى تعييه

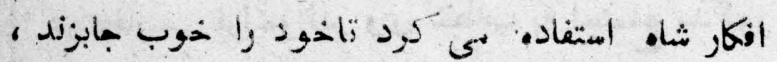

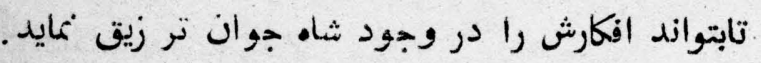

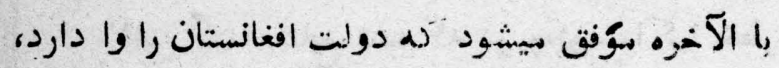

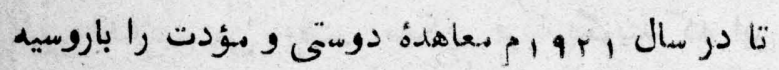

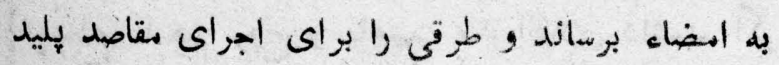

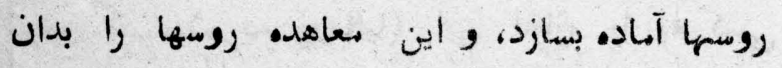

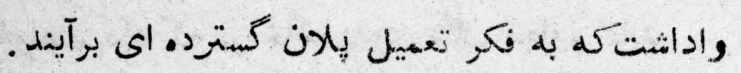

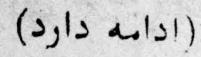

هين خواست، خود را از بلت دانسته و سشى آيند. اش را اظهار نمايد :

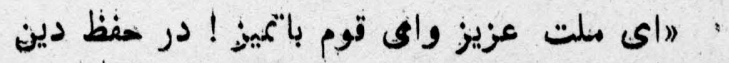

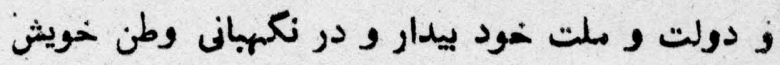

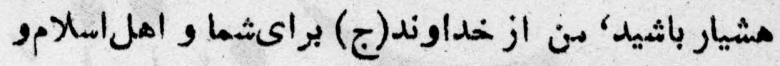

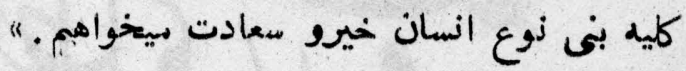

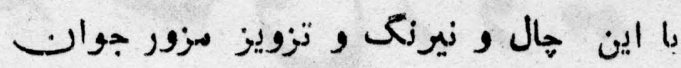
توانست خويش را شياه جوان و مورد حمايت مردم

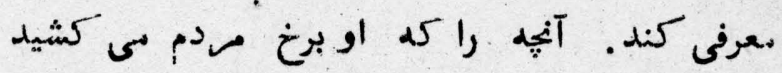

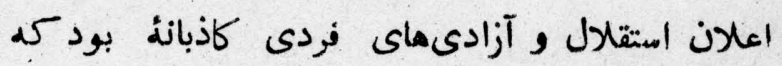

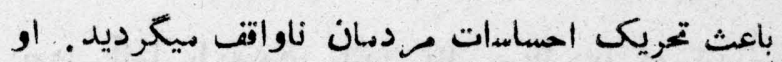

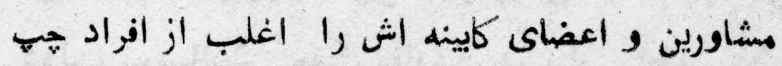

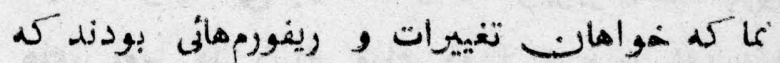

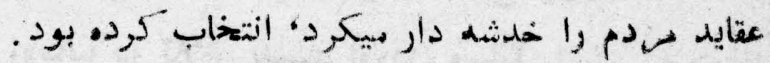

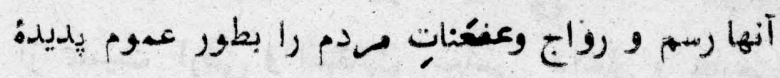

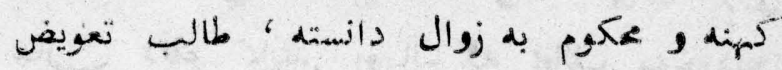
و مبادله آن بودئد. و شاه را بيشتر تشويق مى كردزند كله با روسيه

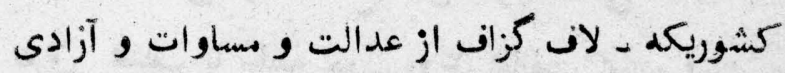

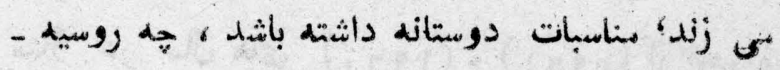

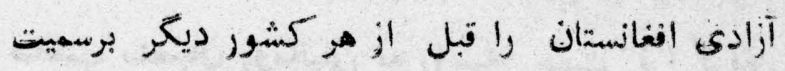

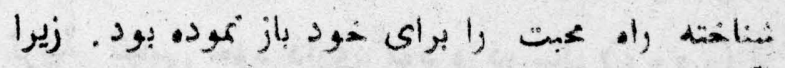

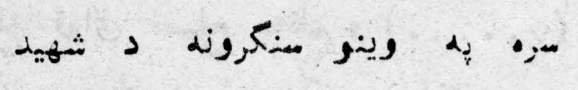

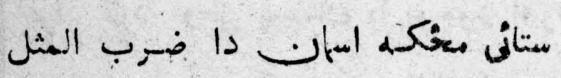

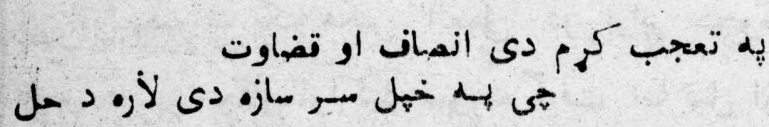
خداى دى كوى تباء به زره تور خاننان

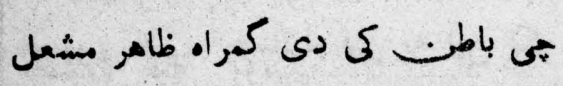

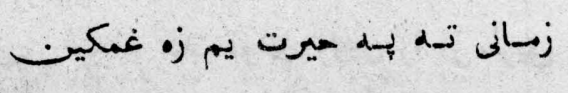

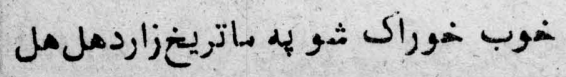

\section{د غمغين اثر}

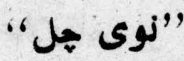

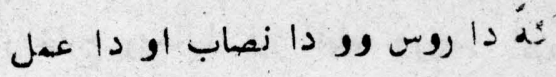

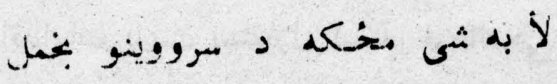

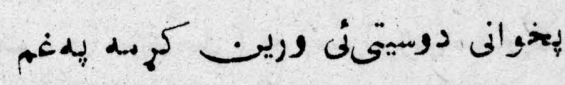

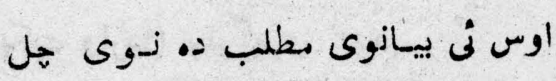

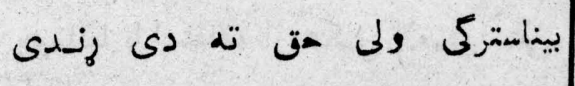

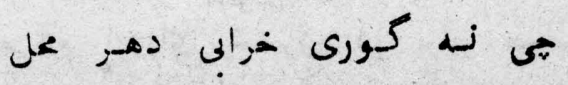

وطسـ كندى كنه والى شو به بمبارد 


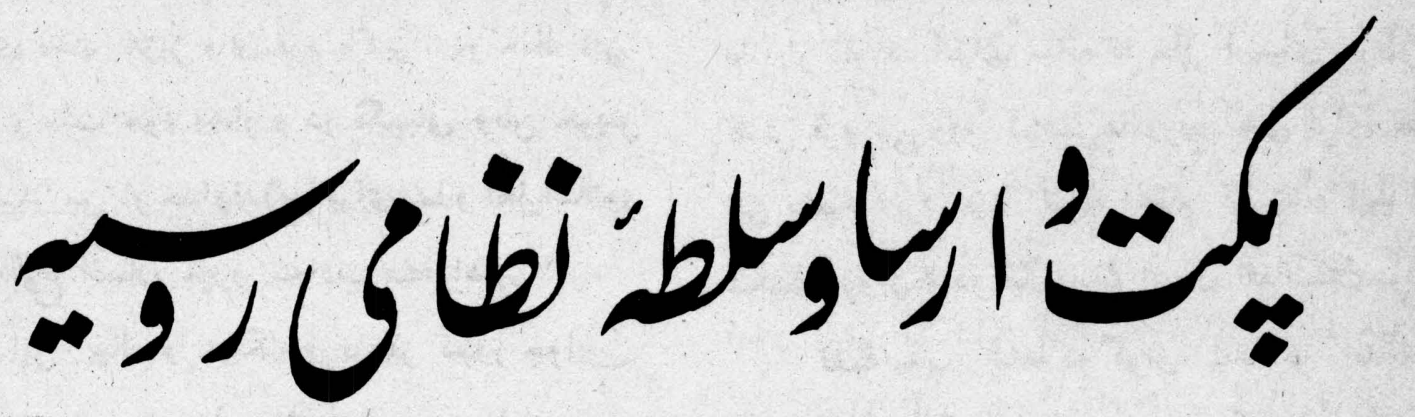

هيومته بكذثته

روميانيn و نظطريس (جنك عموم مردم)

بود. آنها با بيروى ازين نظر هينائي ها كم بايد هر

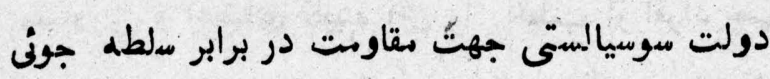

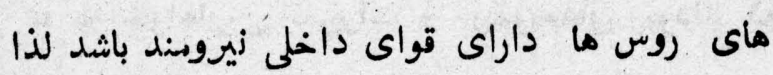

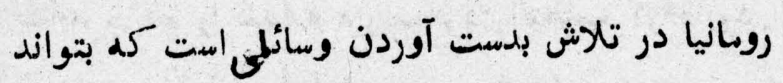

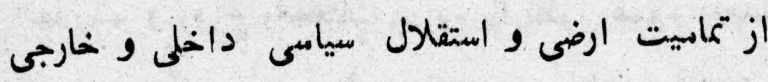

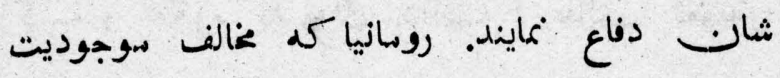

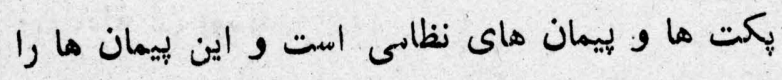

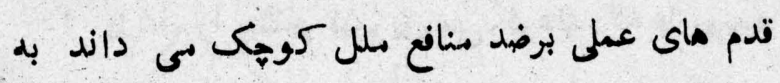

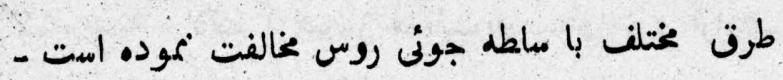

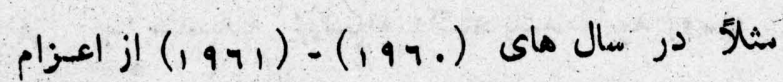

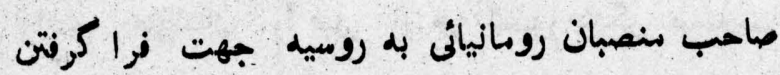

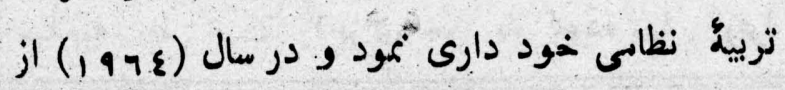

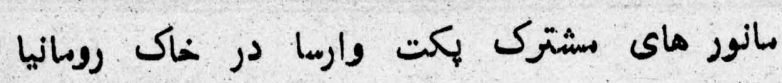

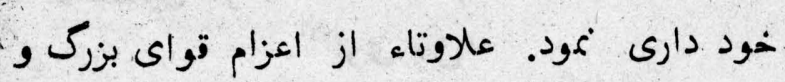

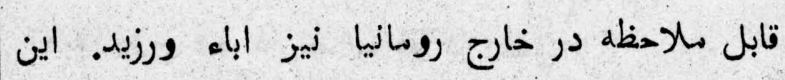
اقدامات باعث استقلال بيشتر فرماندهى عساكر رومانيا

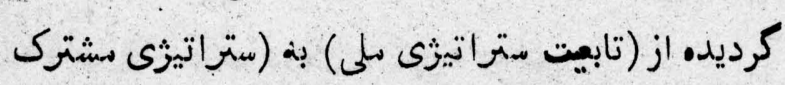
هكت وارسا) جلوكيرى نمود.

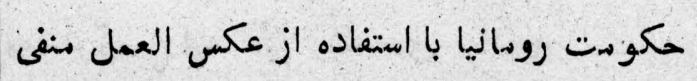

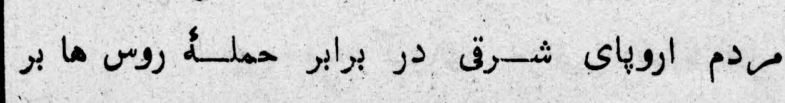
جكوسلوا كيا توانست (سيستم دفاع از كشور) خود
يكى روز بعد از همله زوسها بر هكوسلوا كيا -

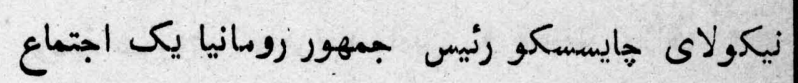

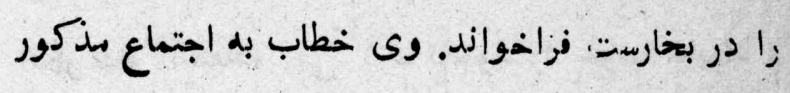
كفت : "اين كنته شايع شد. كله در هكوسلوا كيا خطر ضد انقلاب مى زفت. سمكن فردا بكويند كه اين

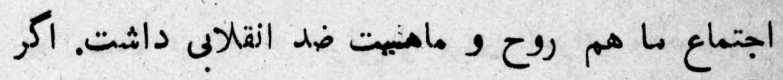

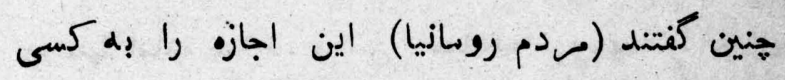

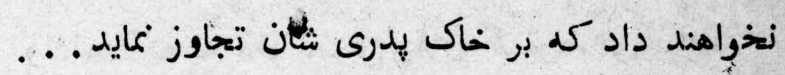

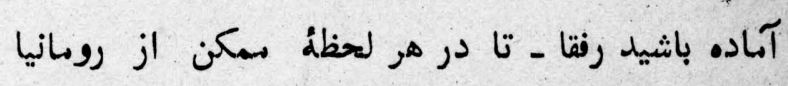
ازين خاك يدرى سوسيالستى تان دفاع نمائيد".

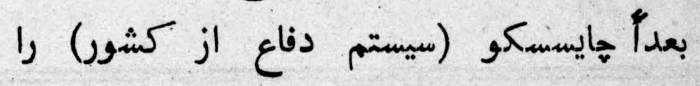

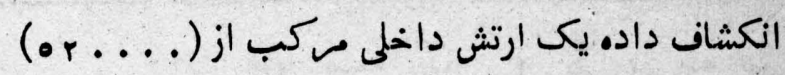

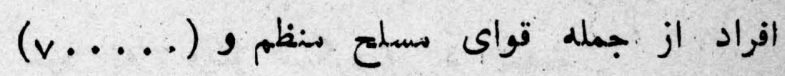

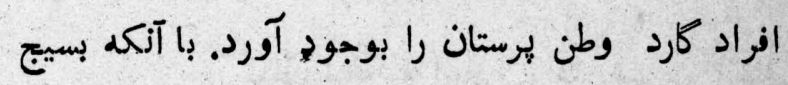

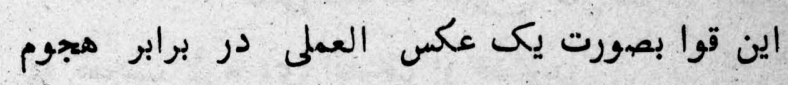

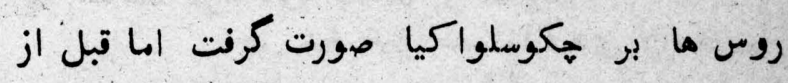

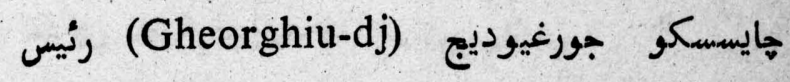
جمهور قبلى رومانيا نيز به اين فكر بود و مقدمات

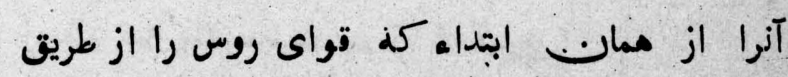

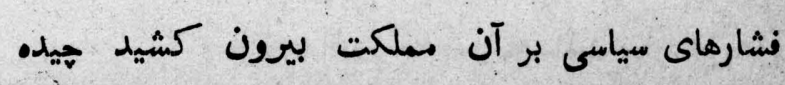


مدمر را آنساده ساخت كه در مقابل هنين اشغال مقاومت نمايند و نكذارند كه متجاوز به اين اهداف لهان

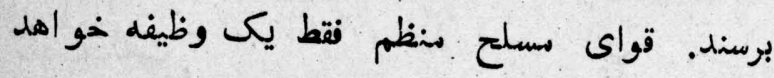

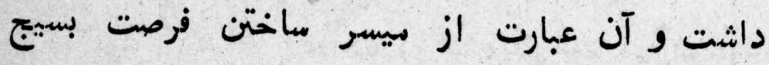

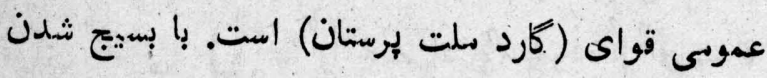

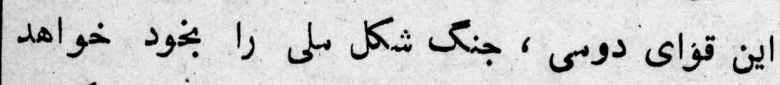

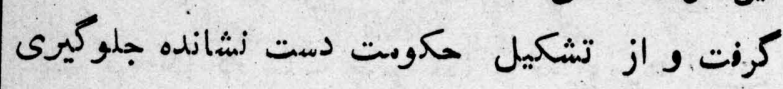

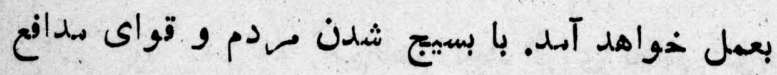

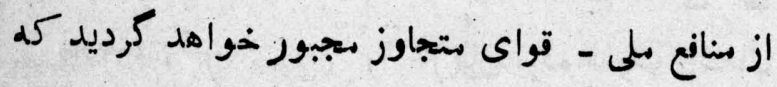

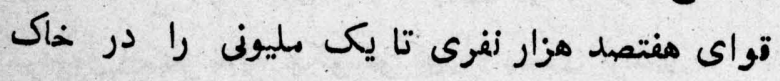

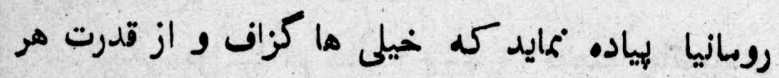

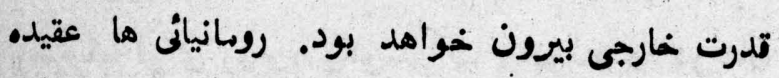

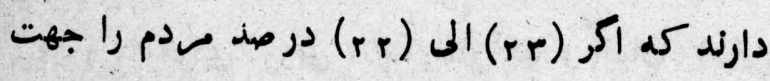

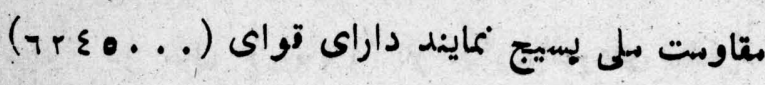
نفرى خو اهند بود.

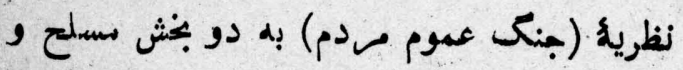
غيو مسلح تقسيم مى كردد. بخشث غير مسلح آن لِّج اساس عمده دارد :

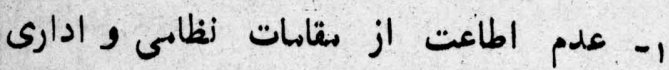
اشغالكر و عدم مسكلرى با دشمن.

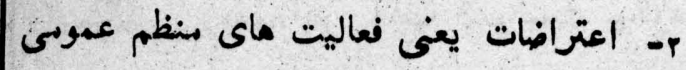
و دسئه جمعى برضد اقدامات اشغالكر در هر ساحه.

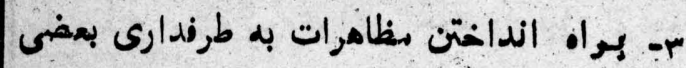

هوضوعات از قبيلن رهائى زندانى ها.

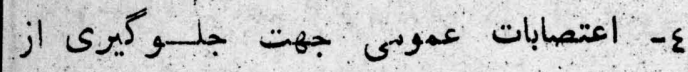
استعلال منابع و وسائل اقتصادى مهلكت توسط قواي اثبغالكر.

ه- - خرابكارى ها و از بين بردن و ختنى 'مودن اقدائات ادارى و اقتصادى دشمن.

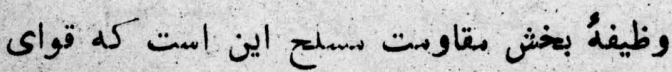
متجاوز را بكونه ماى مغتلف مصروف نكهدارد و
را مثل يوكوسلاويا عصرى مازد. رومانيا با انكشاف

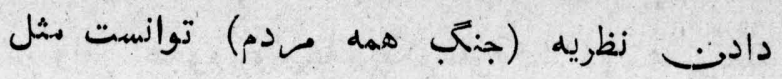

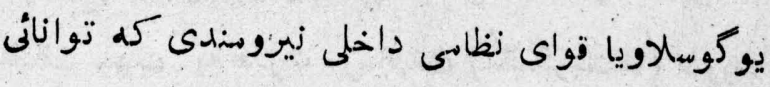

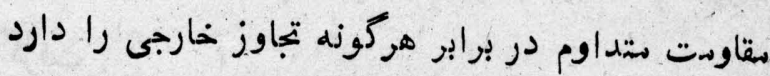

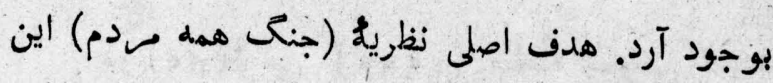

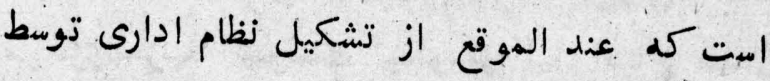

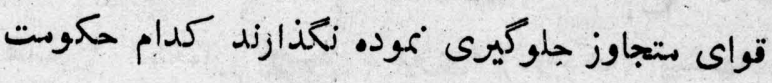

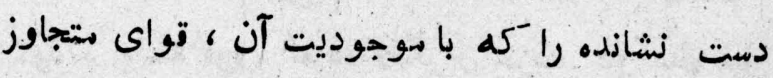

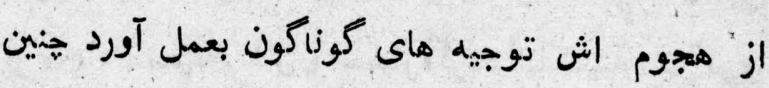

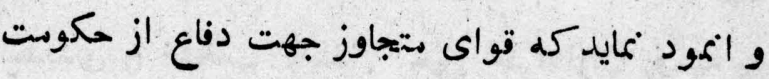
قانونى به حينين عهل دست زده.

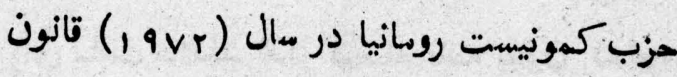

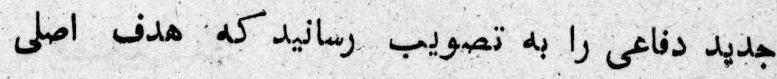
آن اثبات هر هيه بيشتر استقلال نظابى و سياسى رومانيا

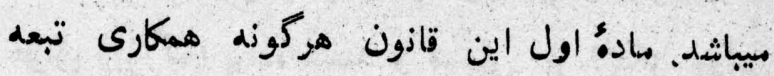

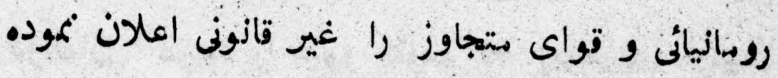
(هيتهس نميتواند تجاوز كدام دولت يا مؤسسة : ريكويد : غارجى را تحت هر كوزه شرايط صرف نظر از ماهيت

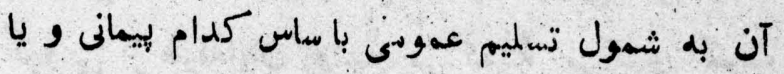

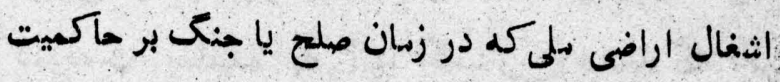

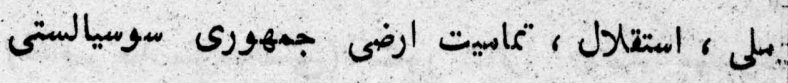

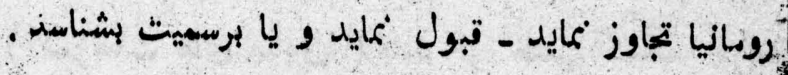
"قبول و يا برسميت شناسى هر كونه ازين اعمال غير

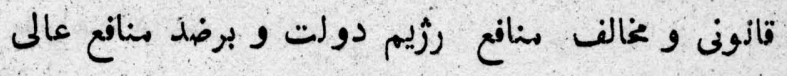
دولت سوسيالتى ما امت.

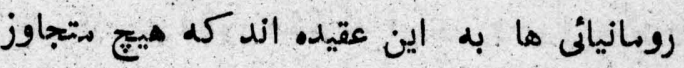

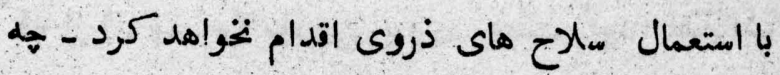

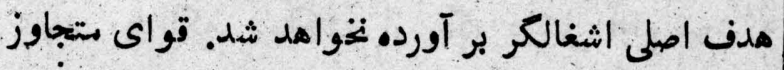

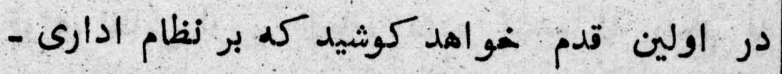
اتتصادى و ارتباطى مملكت تسلط بيدا نمايد لذاء بايد 


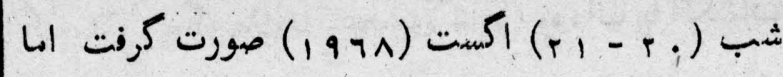
در واقع هجوم روسها برجكوسملوأكيا در مثه مرحلة

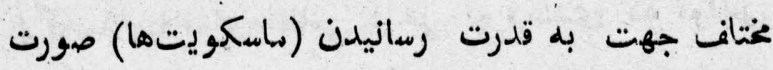

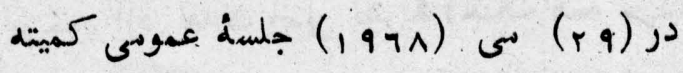

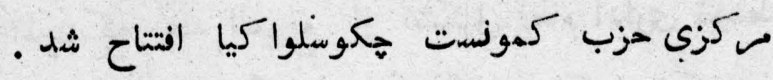
خخالفين استعهار روسيه برهبرى (دوبيكى) بيشنهاد

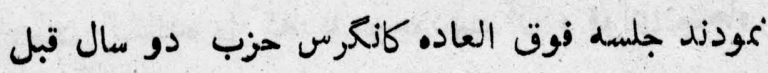

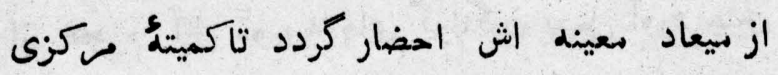

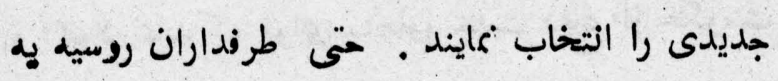

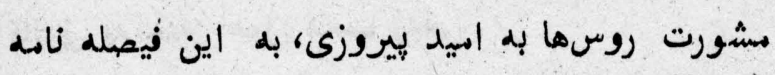

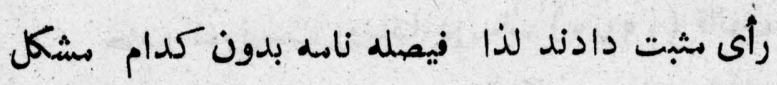

فرد اى آنروز قواى فراشوتى روس در درد ميدان

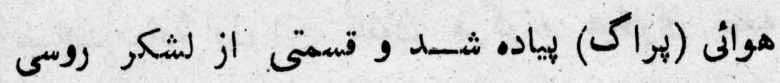

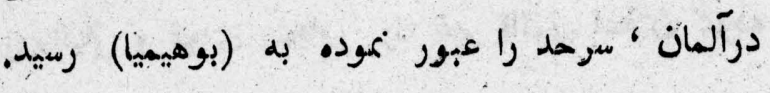

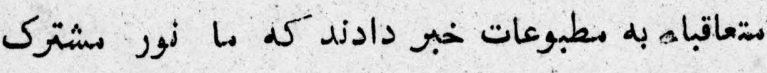

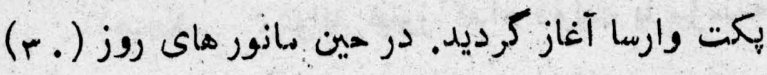

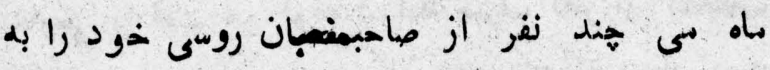

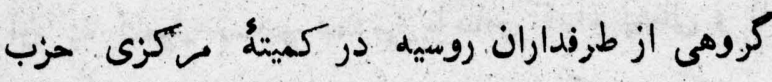

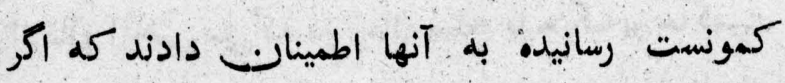

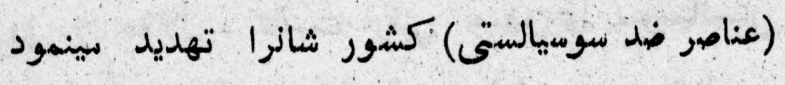

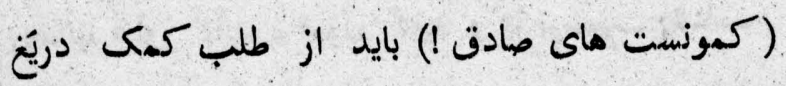

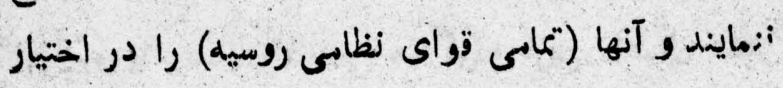
غواهند داشت.

ז- تواى اضافى روسها داخل خاكى هموسلواكيا شد تا در مانور مشترك قواى روس و خكوسلوراكيا

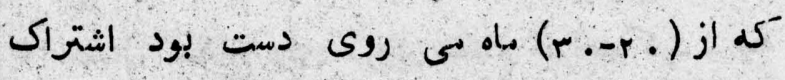

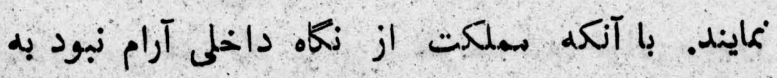

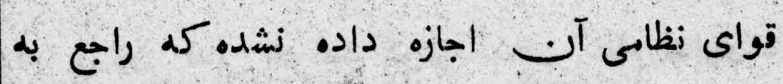
مسائل حتى فكرى نمايد. روس ها با روى دست كرفتن

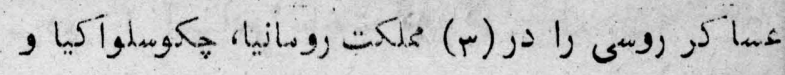

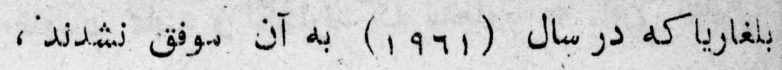
آنساده ساخت روس كله ازين مالكل در تشويش بود مى كوشيد

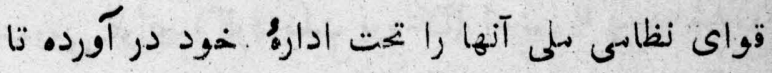

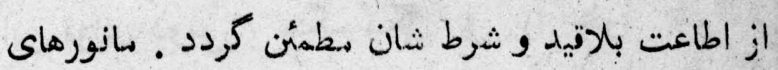

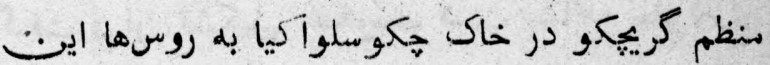

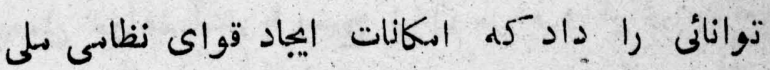
جهت (دفاع از بيهن) زال از بين برده قدرت الشغال سريع و وسيع خاك خكوسلواكيا را بدست آرند .

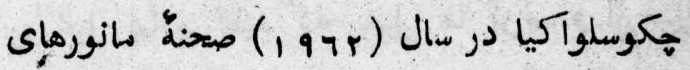
مشترك قواى روس، جكوسلواكيا و يولند و در در سال

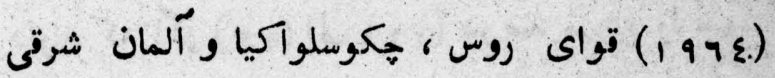

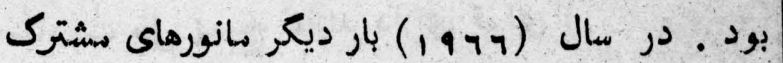

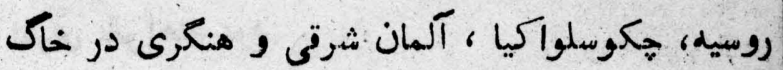

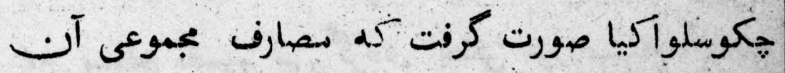

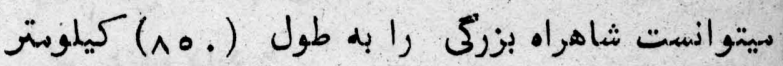
الحداث نمايد .

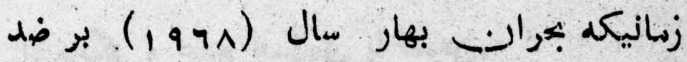

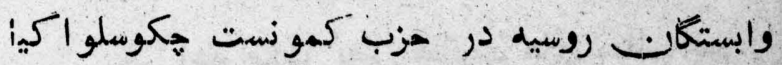

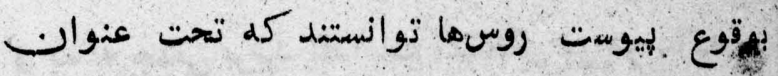

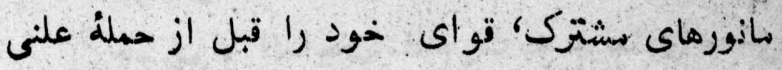

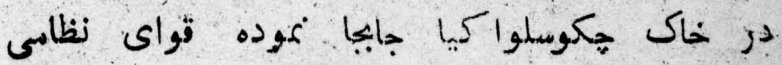
هكوسلواكيا را هم از فرماندهى ملى آن يحروم سازند .

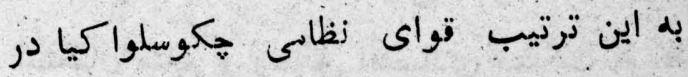

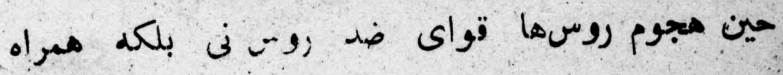

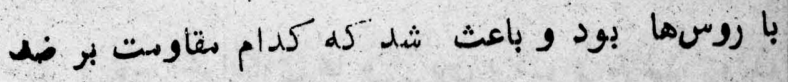
عسا كر روسى صورت نكيرد .

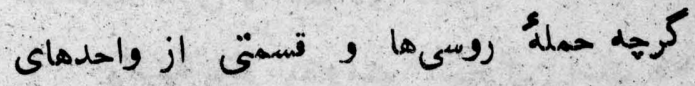

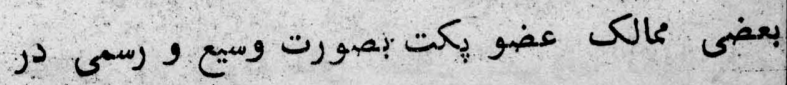


آن مملكت. در مانور هاى (شوماوا Shumava) تحت فرماندهى روس ها مشغول بود و اصلًا فرصت توجه به مسائل ملى را زداشت. بعد از مانور هاى مذكمور در حين مواصلت (مكتوب وارسا) قواى روسى در خاكل

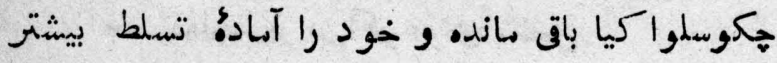
بر اوضاع مينمودند.

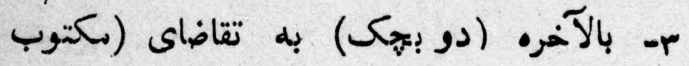

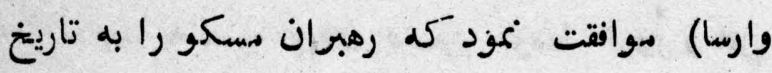

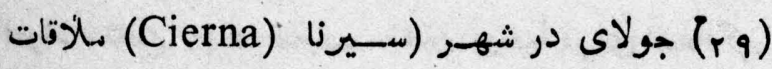

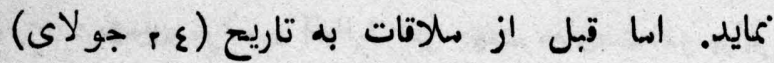

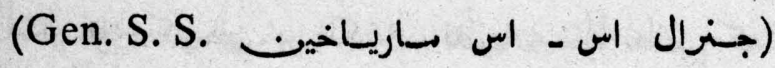

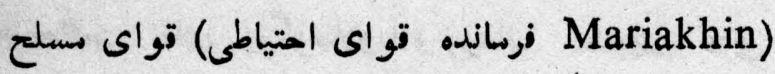
روسيه (نيمان Neman) به تمرينات وسيع لوجستيكى دست زده با ختم مذاكرات (دو بجزك) و فرمانروايان

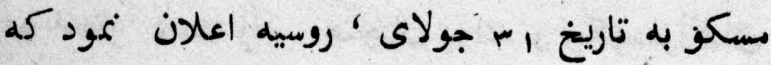

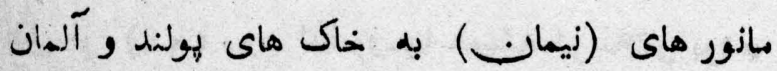

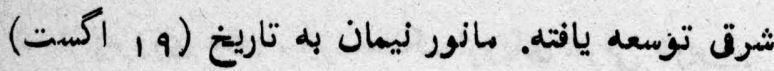

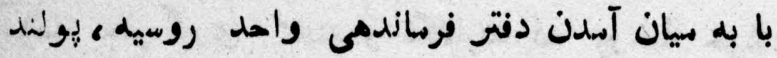

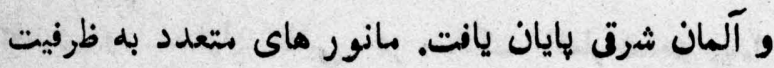

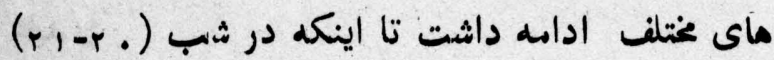
اكست واحد ماي مذكور بر هكوسلو اكيا حملة علنى و رسمى نموده آن سملكت را در اشغال روسيه قرار داد.

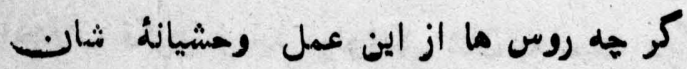
توجيهات غمتلف بعمل آوردزد الما اين عمل ومل غير انساني

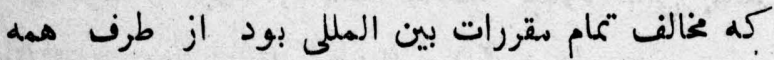
تقبيع شد. حتى سمالك كمونستى شثل حين ، رومانيا

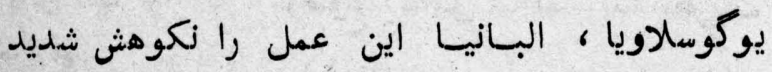
نمودند.

يكى از موضوءات قابل ملاحظه سيستم (كريهكو)

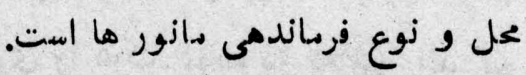

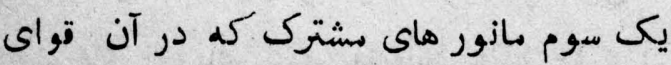
مسلح ملى إولند ، المان شرق و هنكرى در بين سال

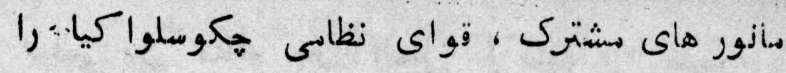

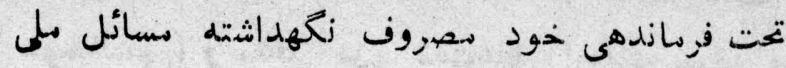
راتحت الشعاع قرار دادذند.

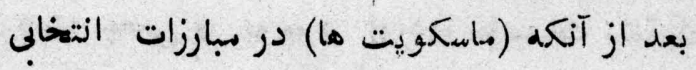

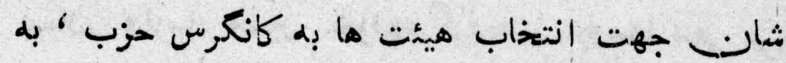

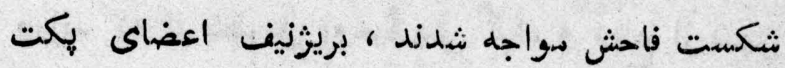

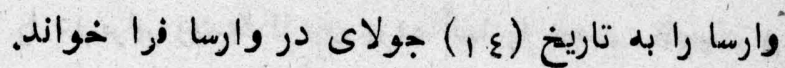

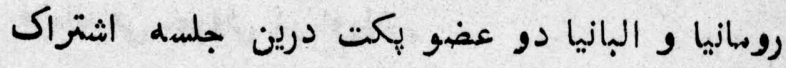

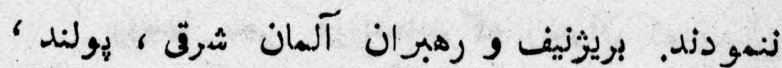

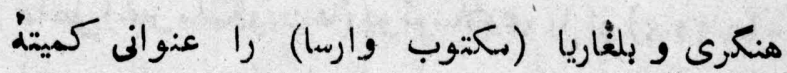
منكزع حزب كمونست هكوسلموا كيا زوشته از مخالفين روسيه درخواست نمودن_ـد كه بايد عناصر طرفدار

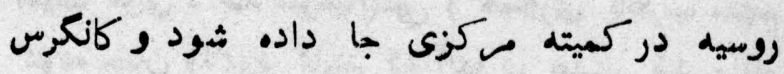

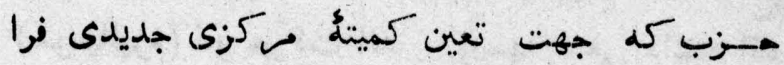

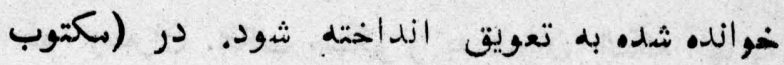

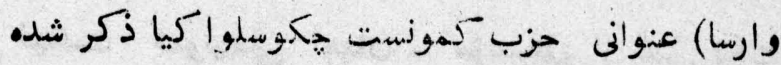

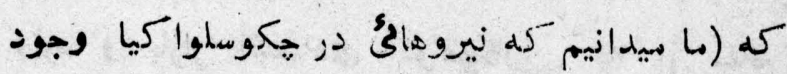

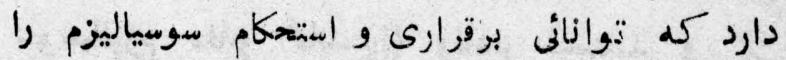

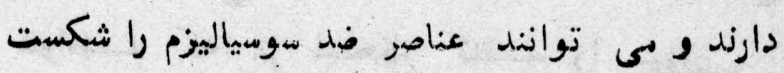

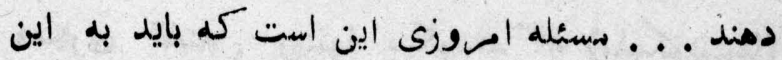

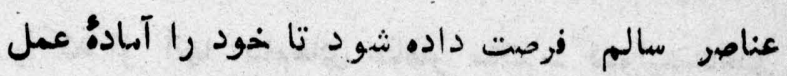
كموده در مقابل ضده ازقلابيون بسيج كردند).

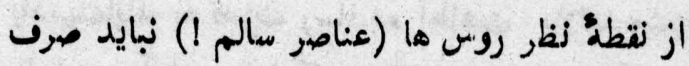

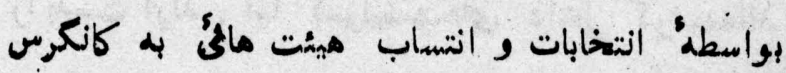

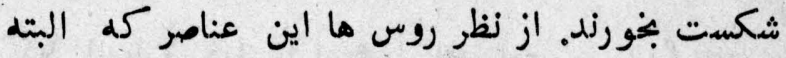

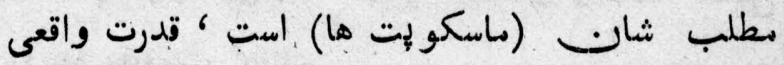
كشور ها مى باثشند. سر مقالةُ روزنامهُ (يراودا) سورخه

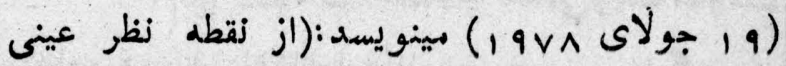

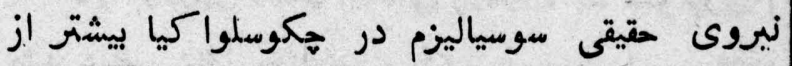

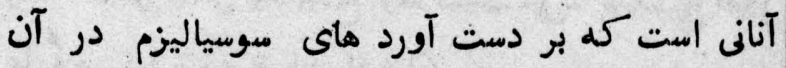
مملكت تاخت و تاز رينمايند. در حاليكه در داخل |رزيم جكوسملوا كيالى ثباتى حكمفرما بود' قواى نظانى 


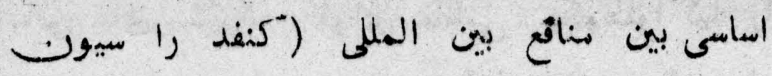

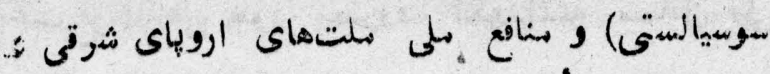

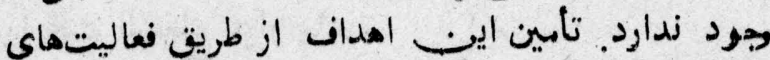

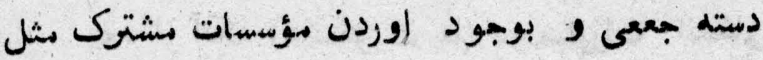

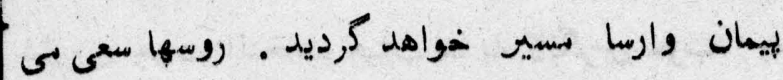

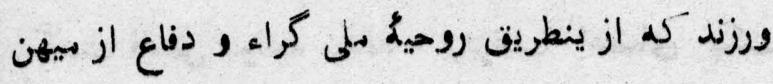
را در برابر روسها از بين مرده آنها را تحت تابعيت و فرماندهى خويش در اورند . روبهها سعى ورزيدهاند كه رهبران كمونيستى

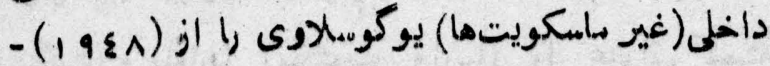

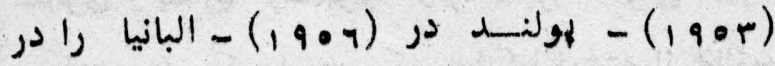

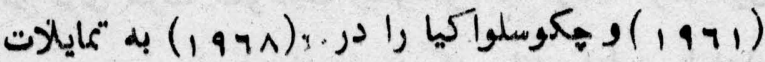

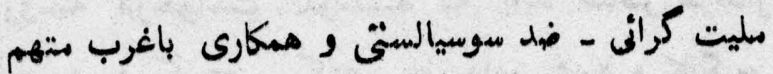

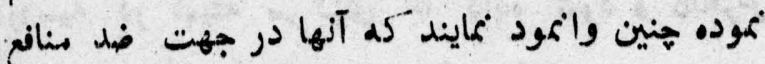

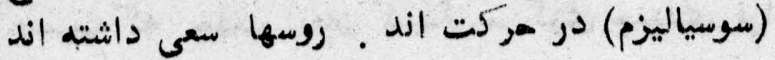

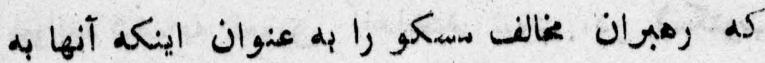

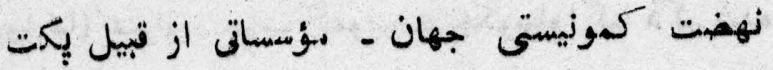

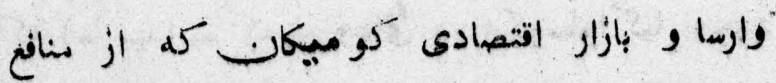

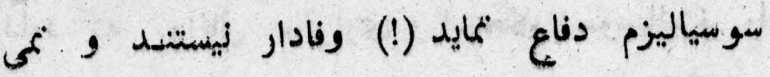

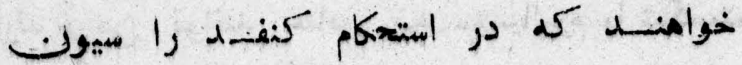

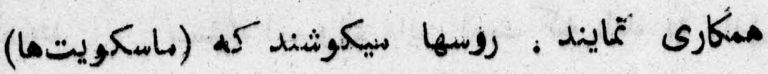

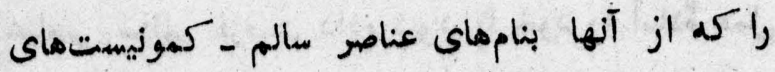

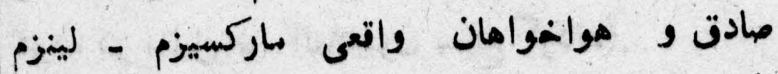

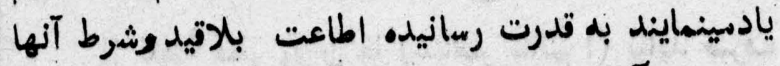

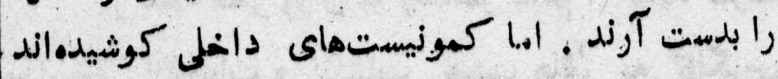

كم از طرق ذيل با استشمار اقتصادى و سلطمة زطامى روسيه مقاومت نمابندد.

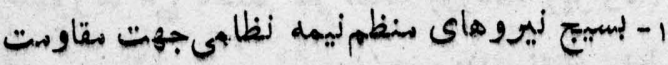

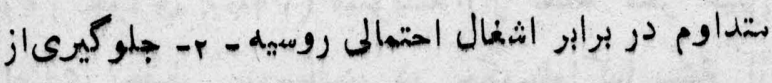

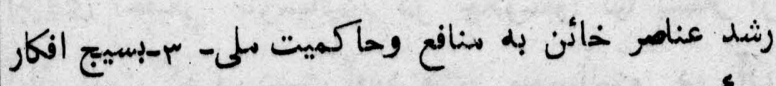
عامله مدم برضد قواى الشغالكر روس .

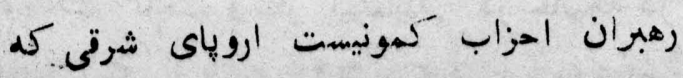

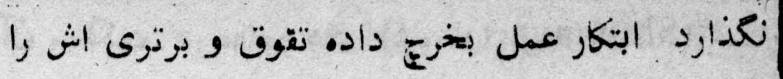

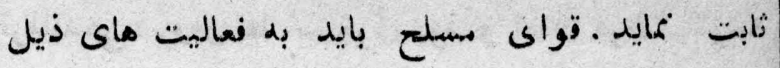
: دزت

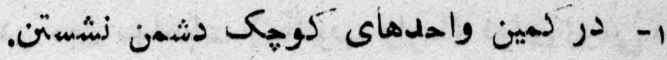
ז- تهاجم بر مساكز قوأى دشمن.

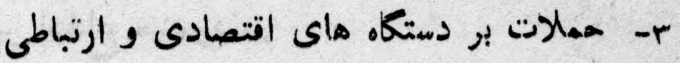
دشن.

ع- به متوه آوردن دشمن توسط ترور و قتل افراد دشعن جهت ضعيف ساختن روحيدُ قواى اشغالكر.

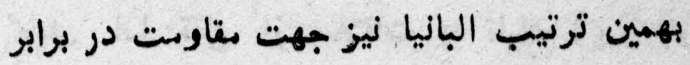

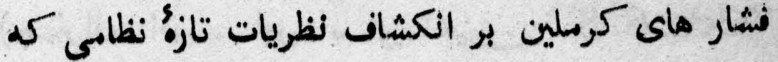

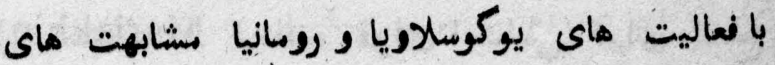
نزديك دارد بردداختند. البانيه نيز در تلاش است كد

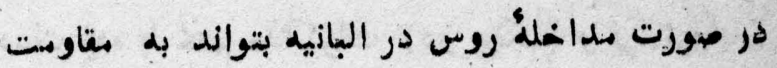

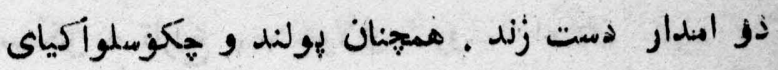

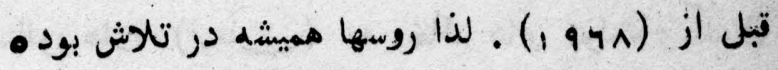

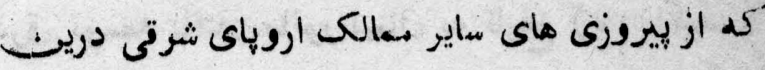

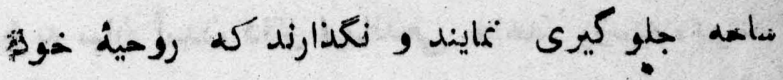

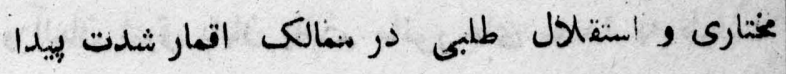

زمبران اهزاب كمونيست اروياى شرقى كد

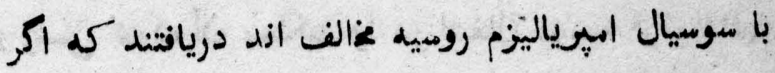

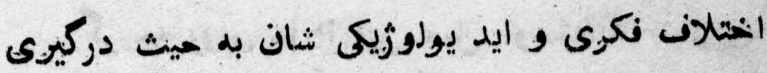
دو حزب و كروه در يكى ساحهd علدود باقى بماند

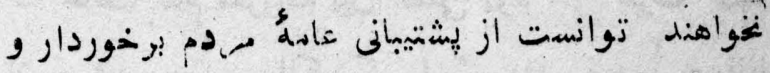

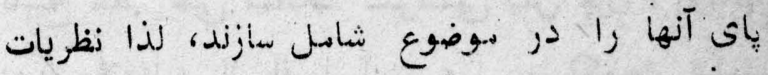

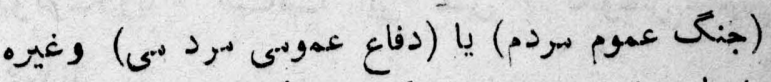

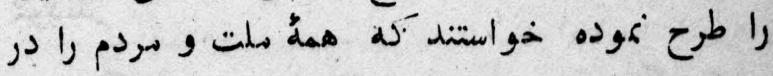
فعاليتهاى خنثى سازى برناسهoاى روسيه دركير سازند.

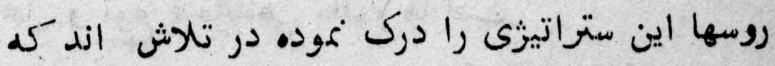

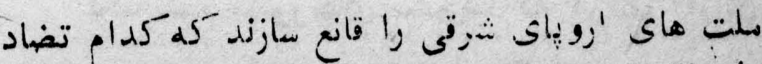


سنكوب 'نودن انقلاب هنكرى" موقف سياسى و نظابى

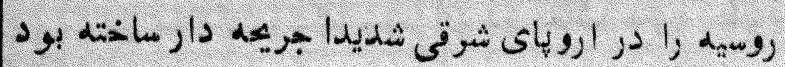

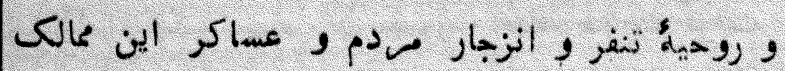

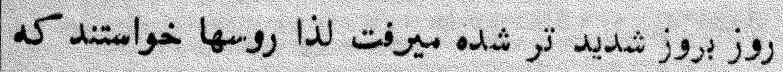

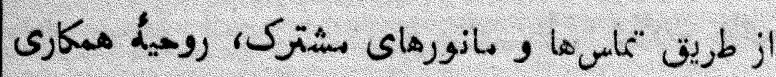

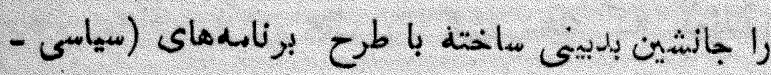

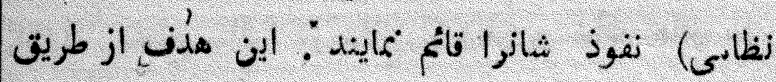

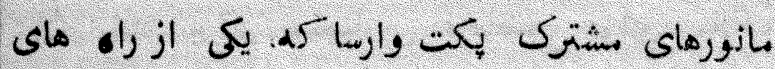
استعهارى روسها است تا اندإزة تأمين ميكرديد.

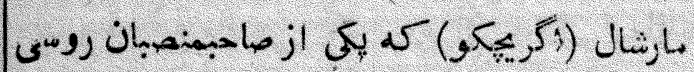
بود در طول جذى جهانى دوم در مقابل نازيها

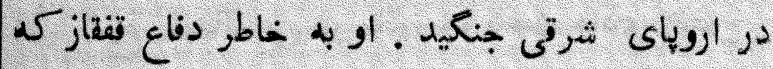

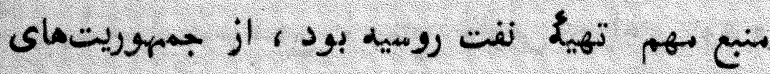

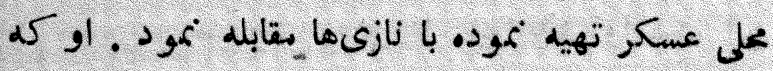

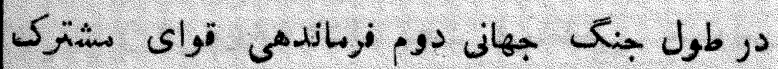
جبهوريتهاى غغتلف را بعهده داثت ترول تبارب زياد

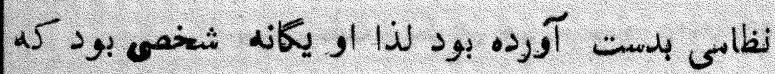
بايد فرماندهى كل قواى لركت وارسا را به عهده كرنته

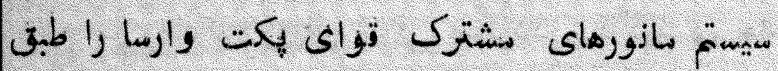
تجارب خويش تنظيم نمايد. او شخصاً مانور بريا رأس اولين مانور بزرك و وسيع بكت بود (Buria) فرماندهى نموده اين مانور كله ساحة بين سوحدات غربن

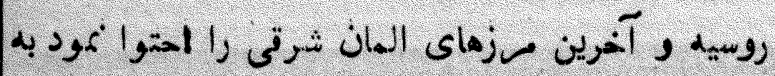

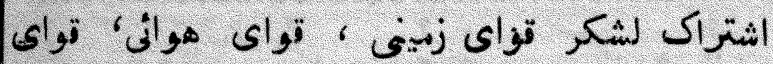

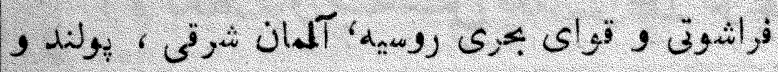

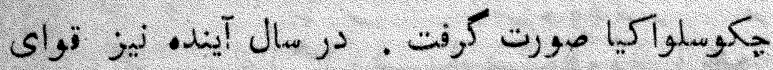
نظانى روسيه و عالكى اروبايى شرقى بـه مانورهاى

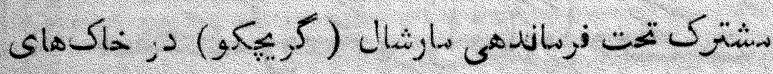

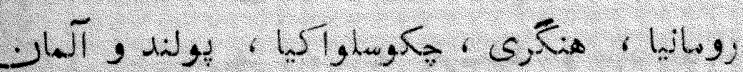

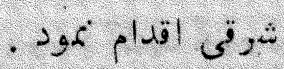
سيستم سارشال كريكيكو زمبينه دوباره داخل ثدن

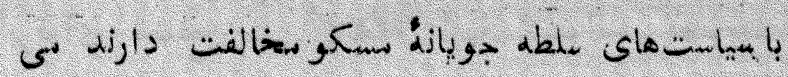

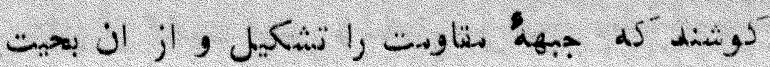

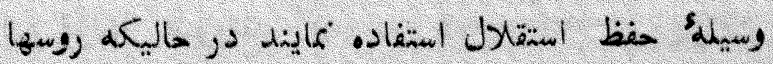

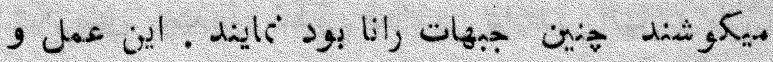

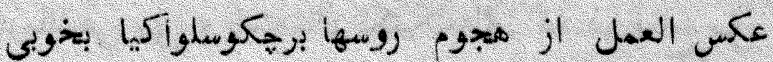
آشكار نى كردد . " ل

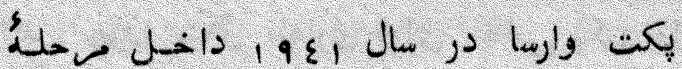
جديدى شد . مارشال كريهيكو در اين سال سيست

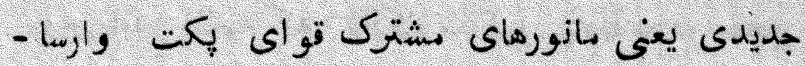
را روى دست كرنت تا بتواند از انكشاف و سؤثريت

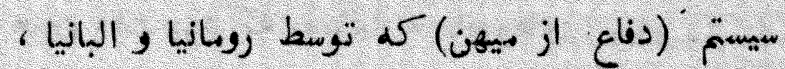

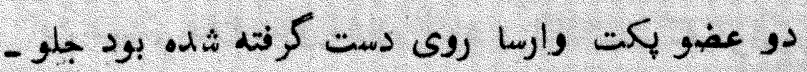

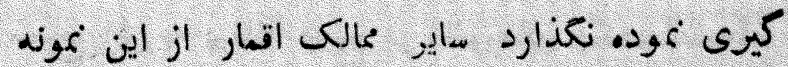

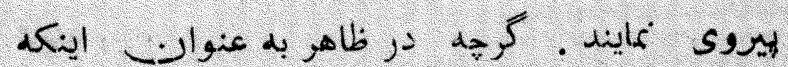

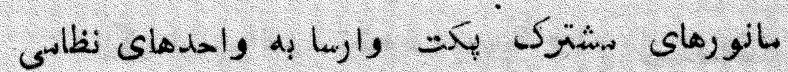

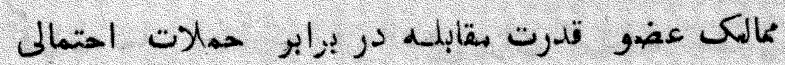
ذروى ناتورا خواهد د.اد اها در واقع اين روشى تازه جهت برآوردن اهداف ذيل روى دست كرفته شد :

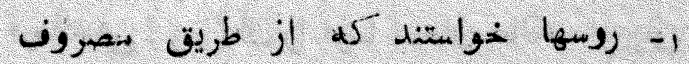

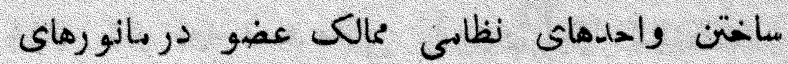

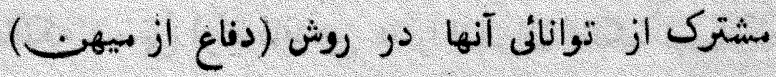
بكاهند

r- بابيا نمون ون واهدماى قواى نظابى روسيه در خاكهاى ممالك اروبائى شرقى , شناطت غربى

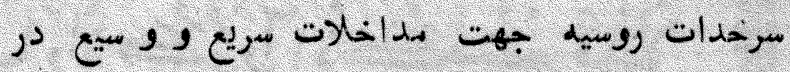
مالكى اروياى شرقى .

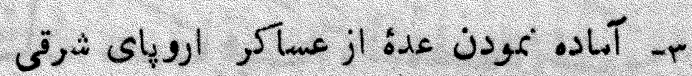
را جهت اشتراك سهبولين در مداخلات روسها در ابور داخلى عمالكى اروياي شرقى .

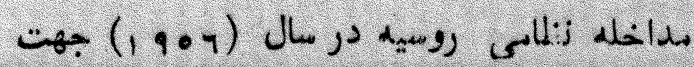




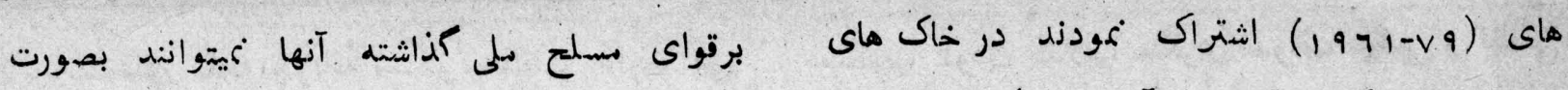

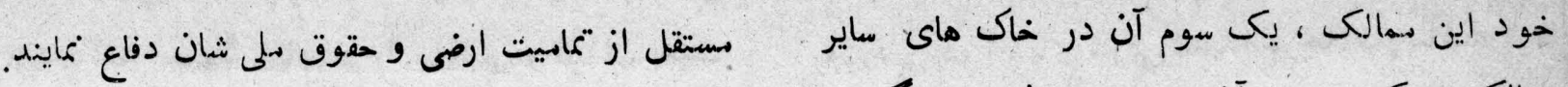

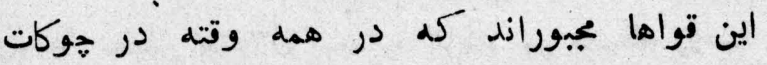

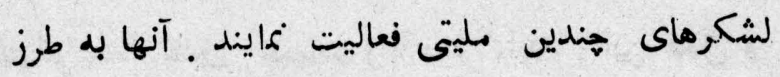

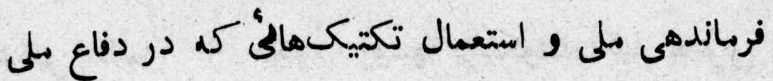

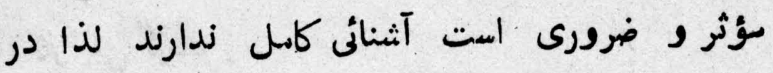

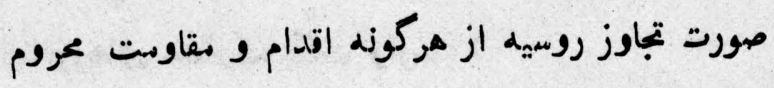

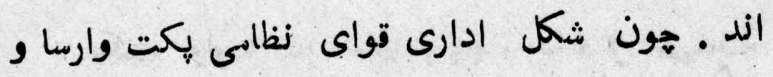

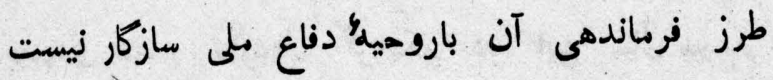

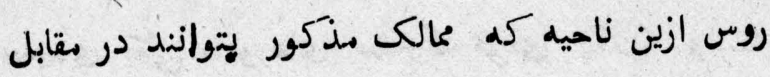

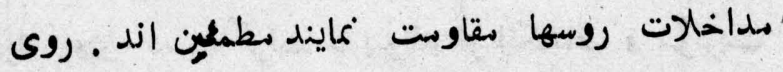

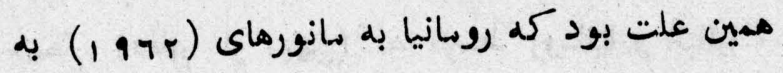

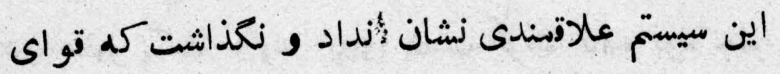
مسلح اش به بيمانگ وسيع در مانورهاى يكت اشتراك مانى نمايند .

يكى از جوازب تضعيف روحيو دفاع ملى بوجود

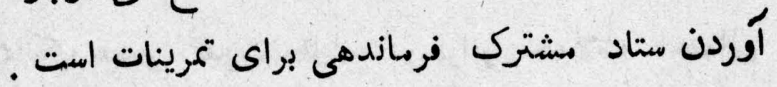

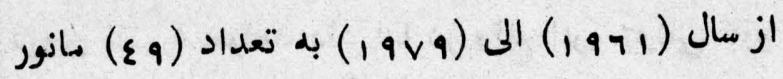

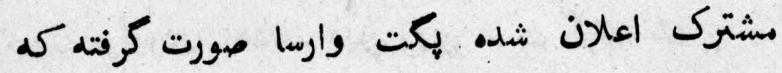
فرماندهى (

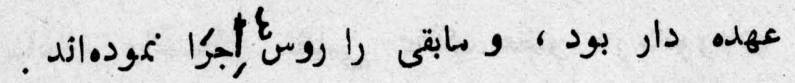

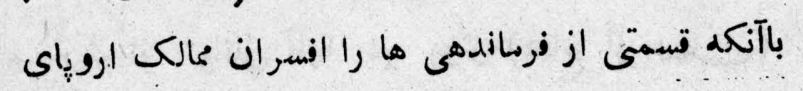
ممالى و يكى سوم آن بصورت مختلط صورت كرفت. در حاليكه از اين نوع مانور ها در خاك روسيه قطعليه

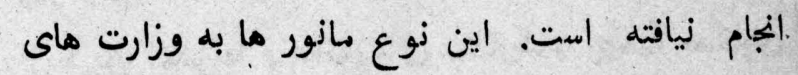

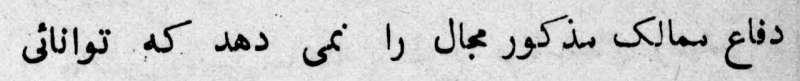

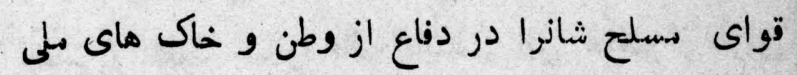

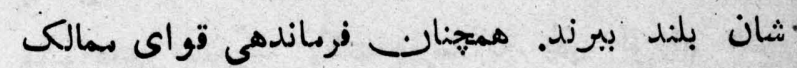

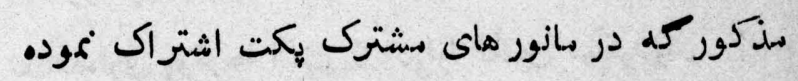

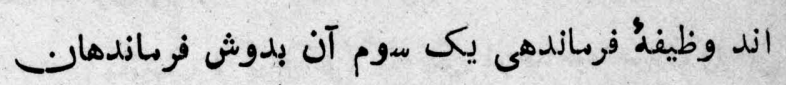

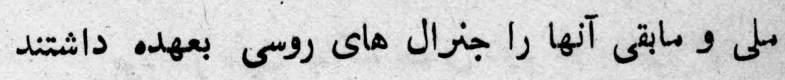

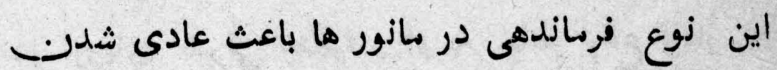

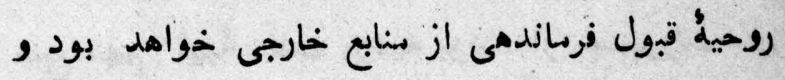

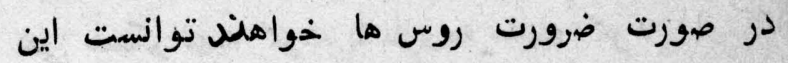

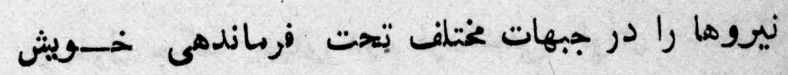
رهبرى نمائند.

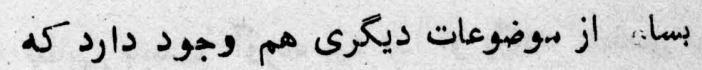
مانور هاى نشترك بكت وارسا باعث تضعيف توانائي

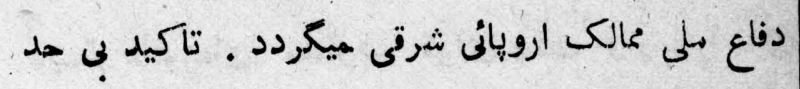

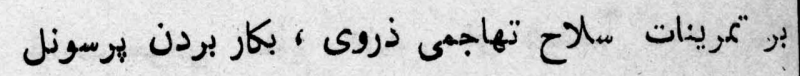

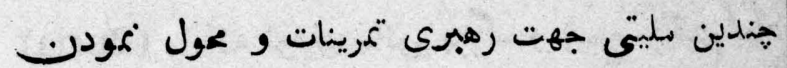

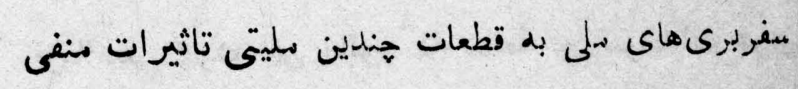

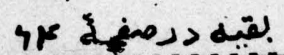

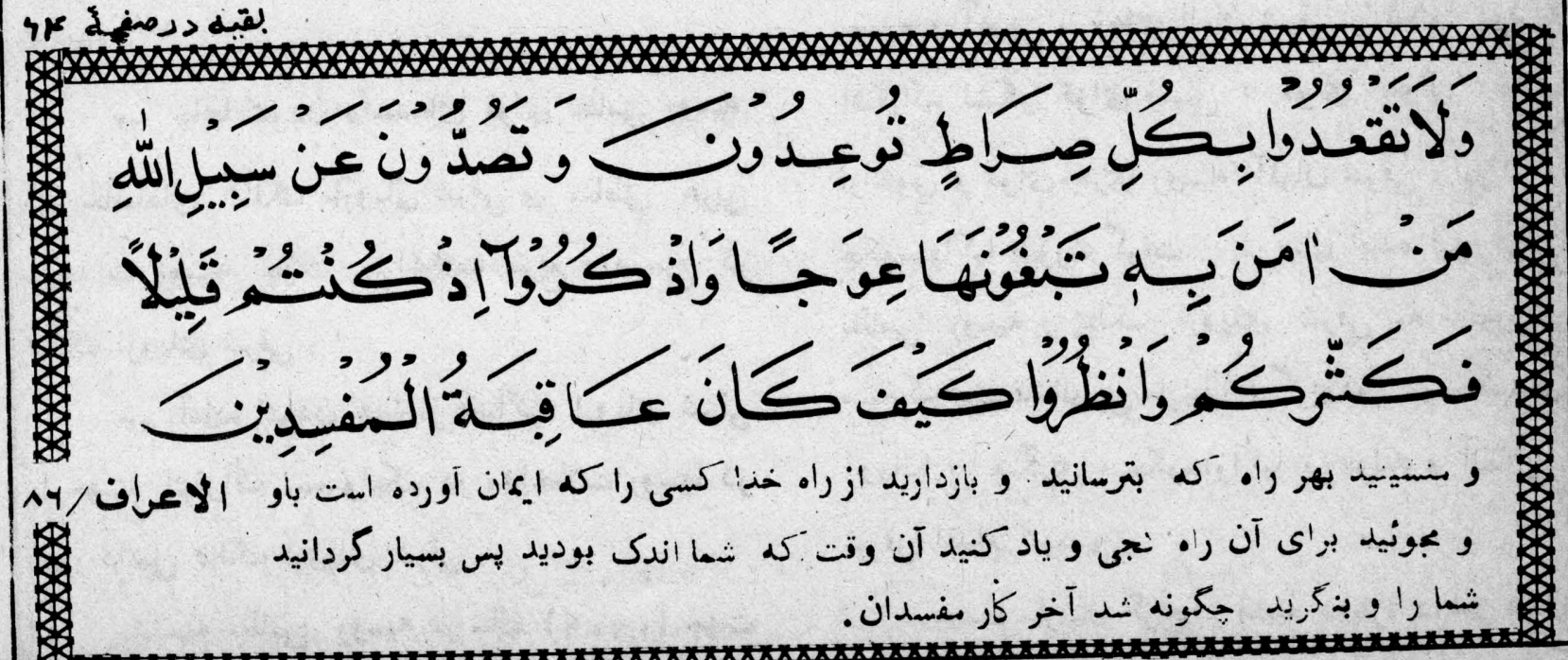




\section{oq}
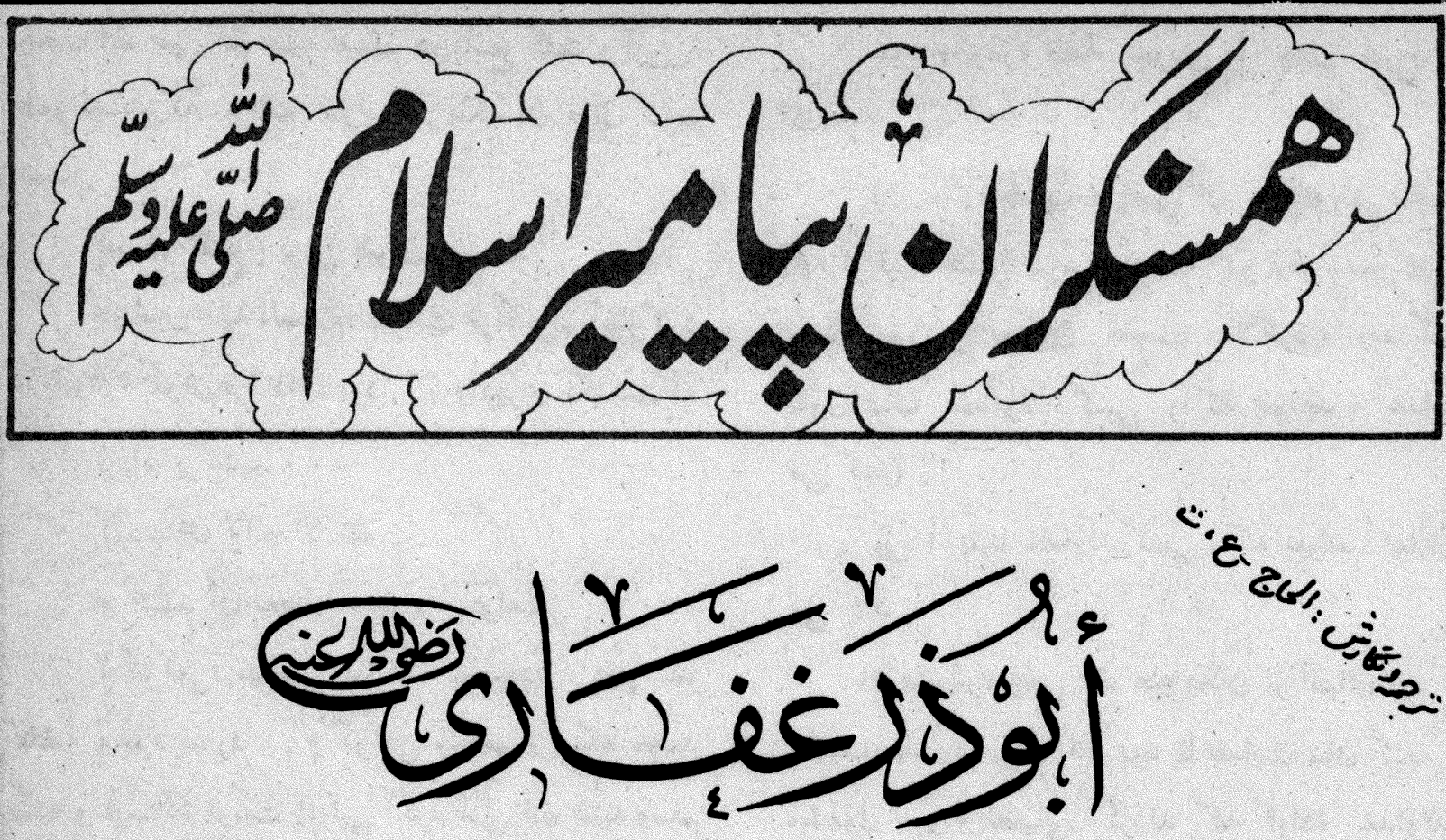

مسدى باثد كل بخاطر وى صحرا ما ما رابيموده است

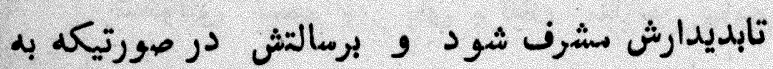

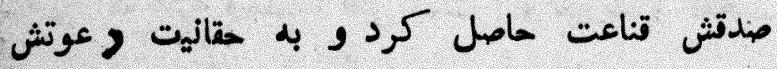

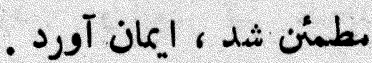

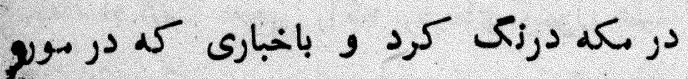

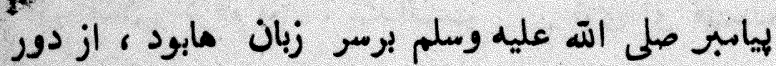

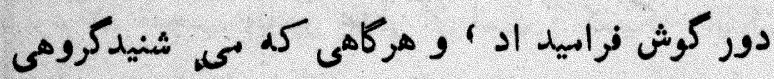

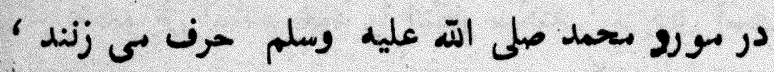

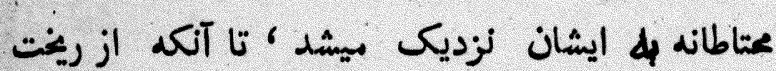

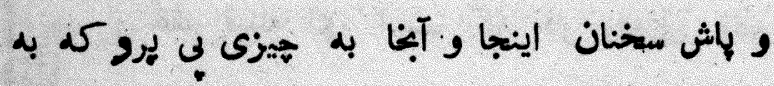
شوى معمد و جائبكه ميتواند در آن جاوى را ييند

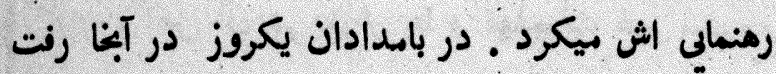

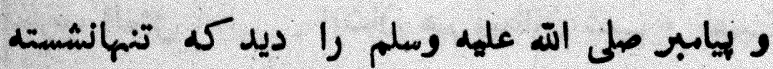

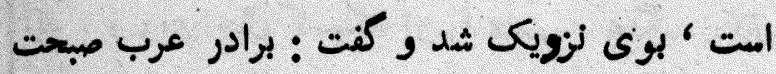
- بنير هيامبر عليه السلام باسغ داد :و سلام برتواى برادر عرب. ابو ذر كتت . از آيهه ميدانى براى من بسراى
با تلبى سرشار از سرور و خوشى به مبوى مكه

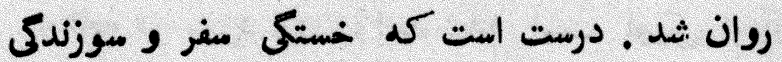

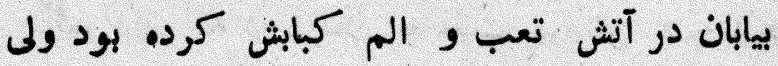

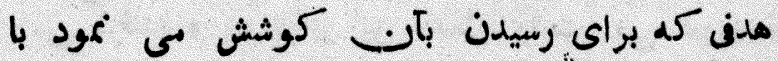

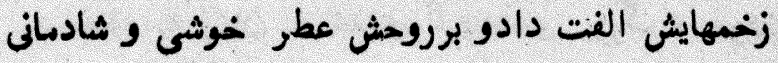
و بشارت را افشاند . مشهون غريبه اى به مكه داخل شد ، توكويى

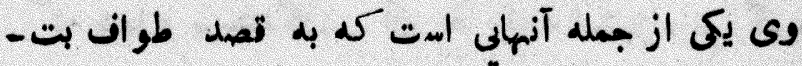

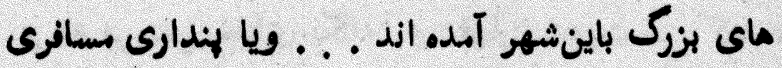

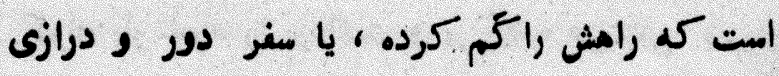
در اييش دارد بـ راه زيادى ليسوده است و باينجا (مكه)

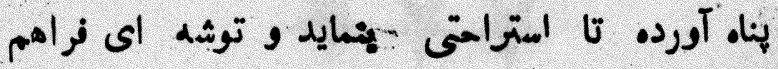
كند . اكر اهل مكن ميدانستند كم وى را جستجوى

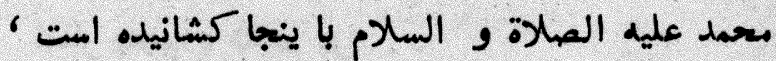

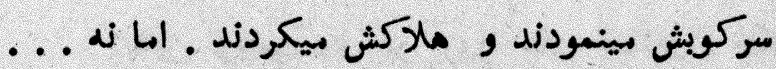

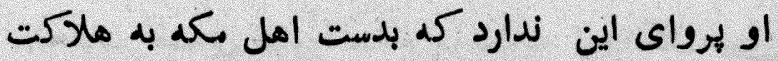

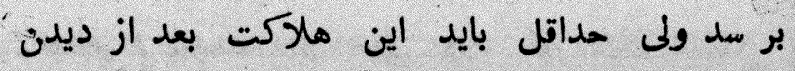


خود "ابوذر" قصن خويش را جنين شرح بى $:$ S

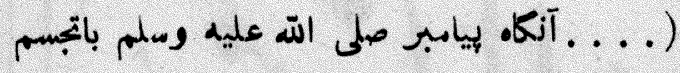

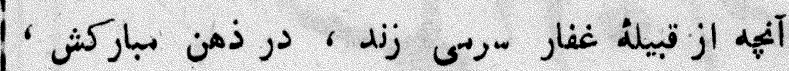

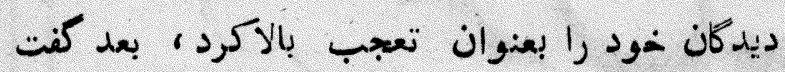

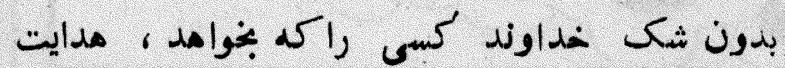
بلى ، بقينا خداوند كسى راكه بخواهد ‘مدايت .

و "ابوذره" رضى اله عنه يكتن از آنهاى بود كم

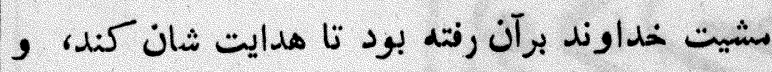

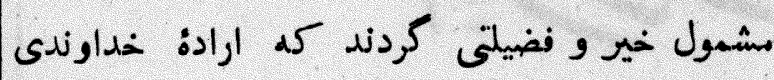

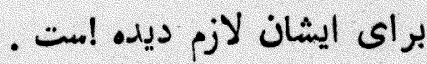

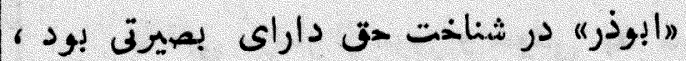

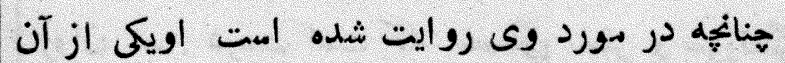

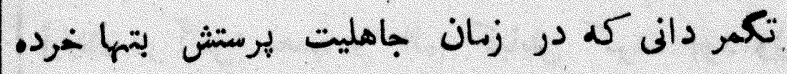

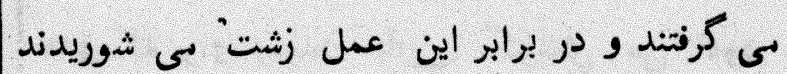

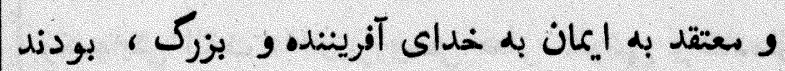

$$
\text { بشمار بى رفت . }
$$

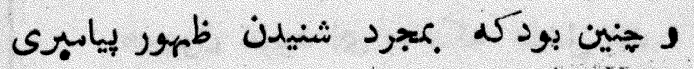

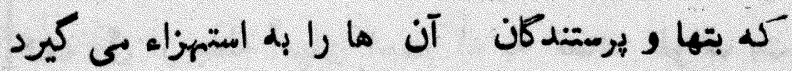

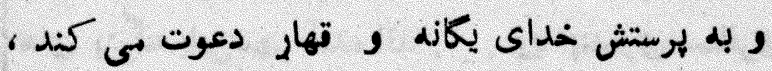

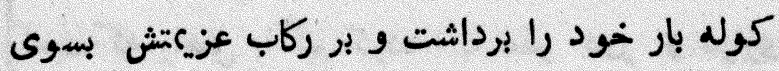

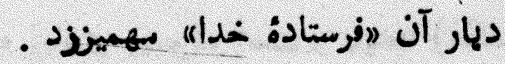

\section{MY2Y}

"ابوذر" . بمجرد رميدلث به ديار يارمسلمان

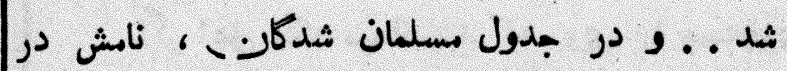

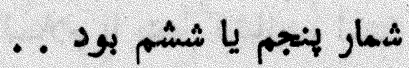

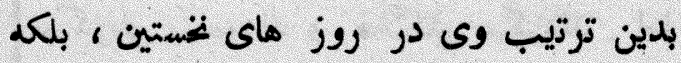

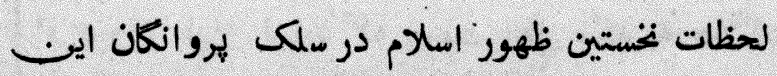
خلجزراغ ليوسته ، و خيلى زود نور تابان اسلاز

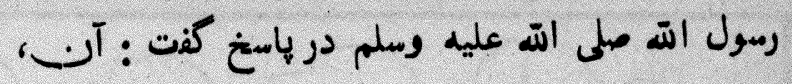
شعر نيست كل برايت سرايم ، بلكه آن قرآن كريم عليم

$$
\text { ابو ذر كنت : برمن بخوان }
$$

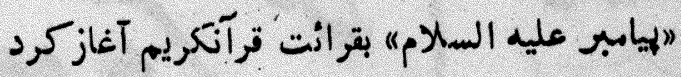
و "ابوذر" كوش فرا داده بود .... و ديرى نكذشت كنه

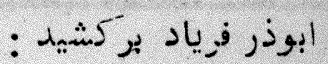

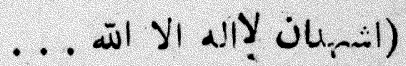

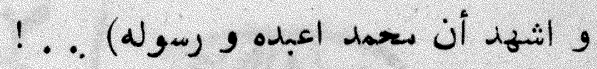

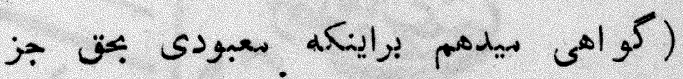

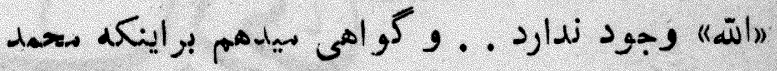

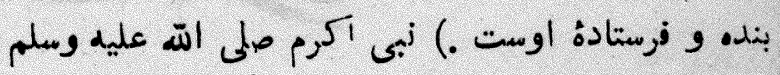

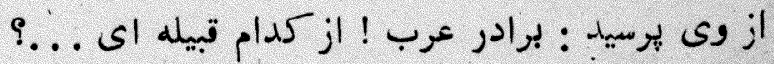
ابوذر جواب داد : از غفار .

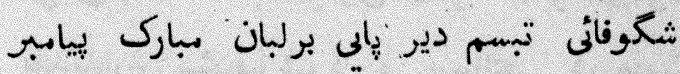

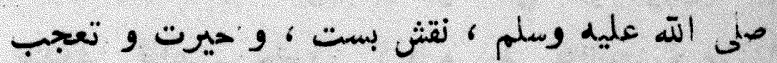

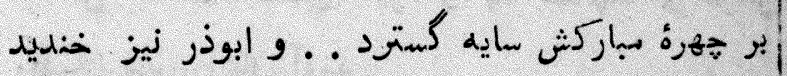
جهه ، او علت تعجيى راكه برسيماى رسول عليه السلام

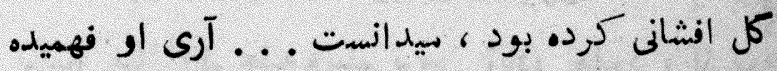

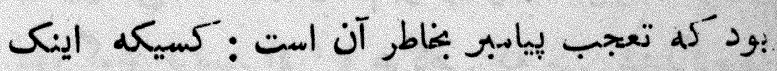

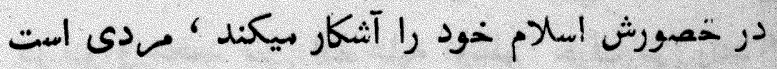

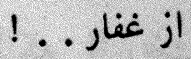
و غفار قبيله اى است كد در راهزنى نظير

$$
\text { ندارد . . . . ن }
$$

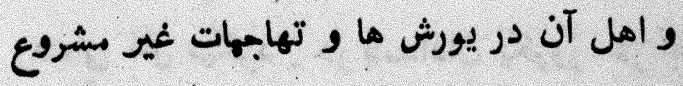

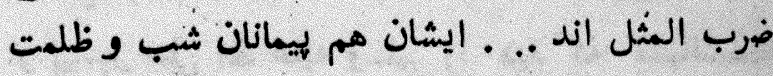

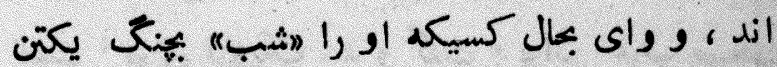

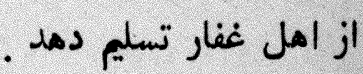

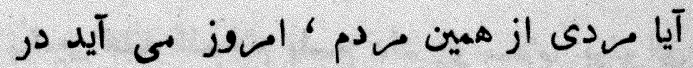

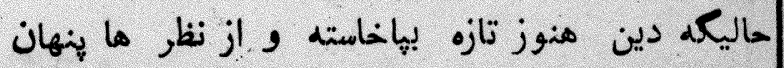

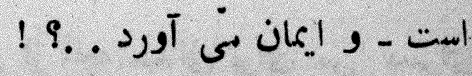


همزمان با مسلمان شدنش، از بيامبر عليهالصلاة و السالم برسيد : اى فرستاوة خداوند ، به خه دستورم ميدهى . .

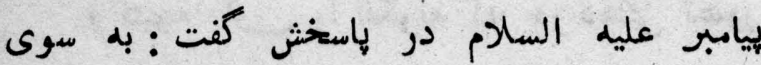

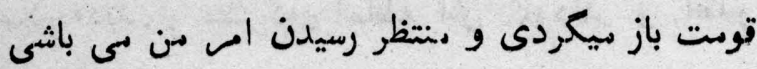

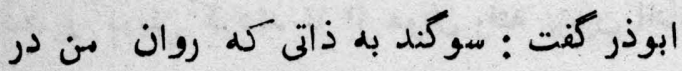

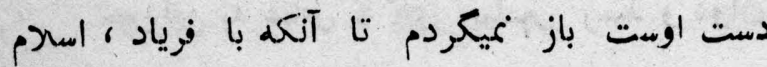

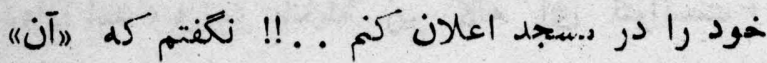

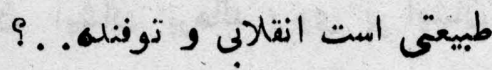

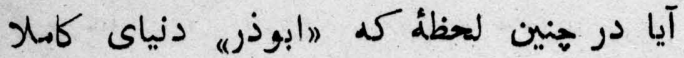

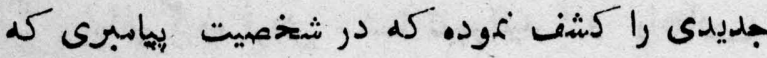

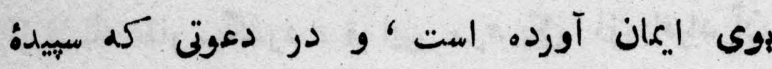

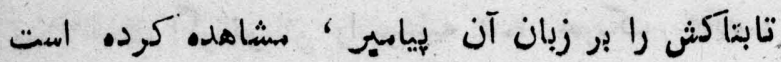

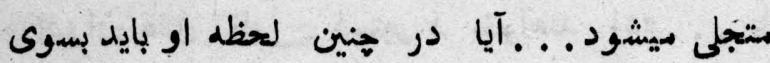
املث خاسوشانه بركردد ؟.... اين كاريست بالاتر از طاقت وى . . .

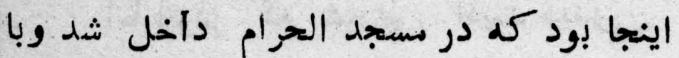
صداى بلند بانك برآورد : أشهداكَالا اله الا الهه ...واشهد أبلـ محمدا" رسول اله.

اين فرياد ـ تا آبخاكه ما ميدانيم ـ اولين فرياد

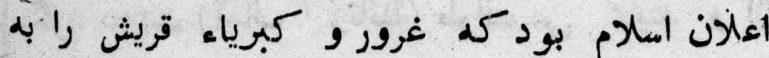

سر زمين وجود او را تسخير كردده بود . زمان اسلام وى مصادف با اياسى بود كم بييامبر صلى الهه عليه وسلم دعوت را سرى و بشكل

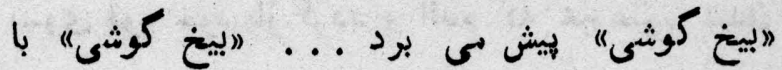

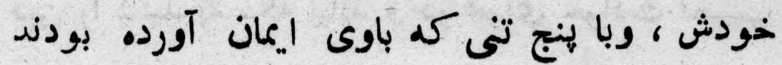

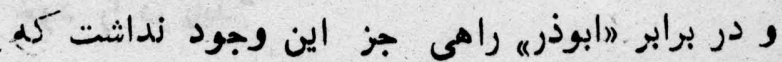

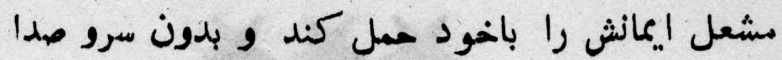
كه را بسوى قوم خود ، ترك كويد . . ولى ابوذر - جندب بن جناده _ داراى طبيعتى نرون است شورنده و طوفانى. او براى اين آفريده شده است كم برعليه به باطل

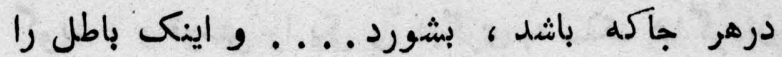

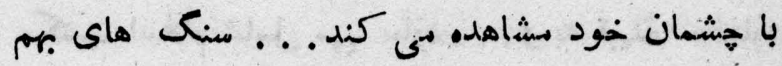

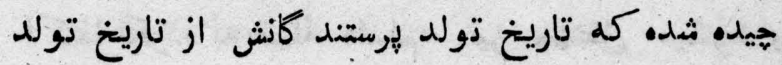

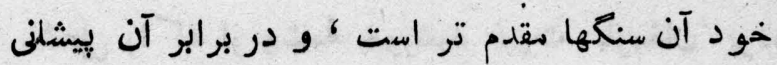

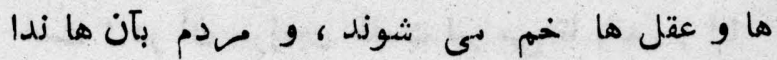

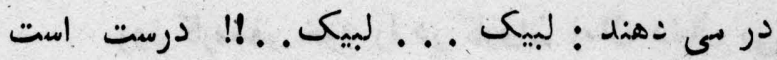

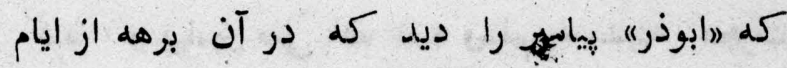

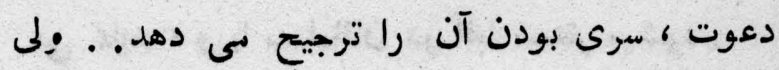
به عقيدة وى ، ضرورت بركملبانك فريادى كم از حنجرة

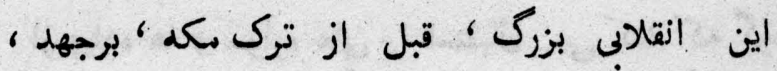

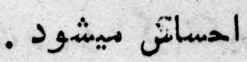

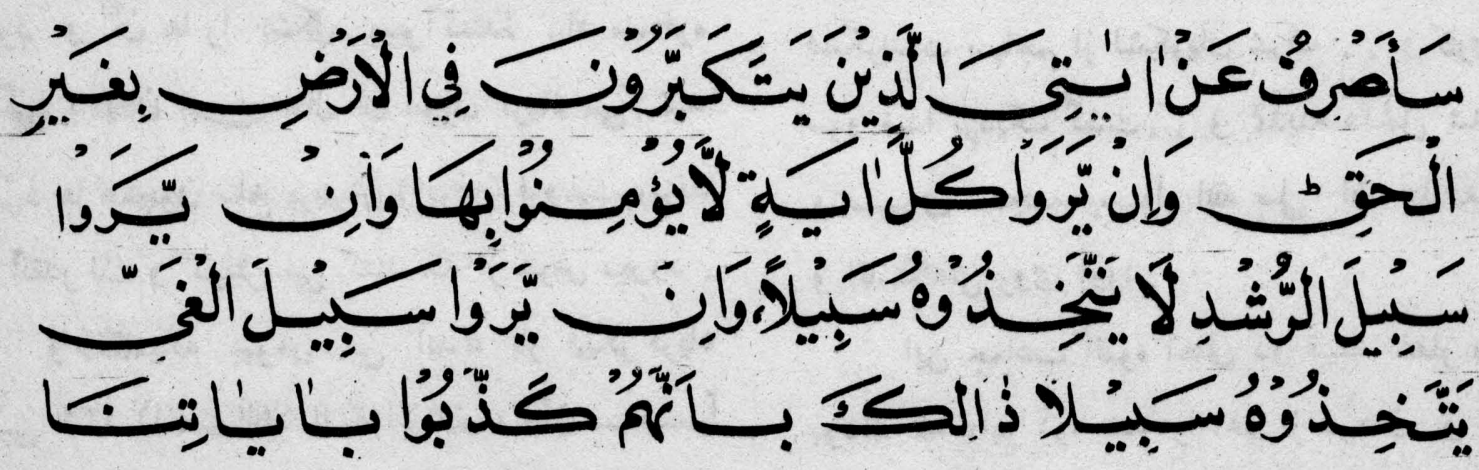

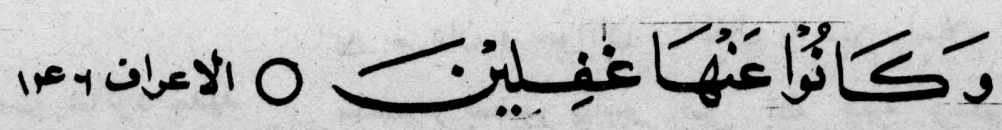




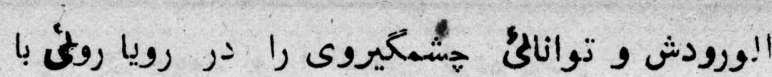

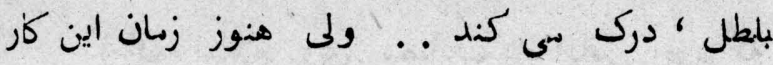

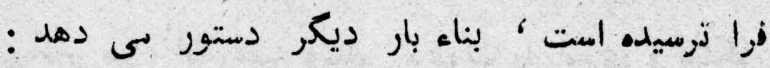

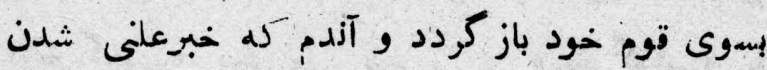

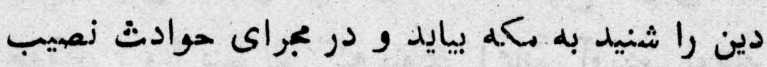
خود را در يايد:

\section{MYM}

و "ابو ذره" بسوي قبيله و قومش باز ميكردد ه

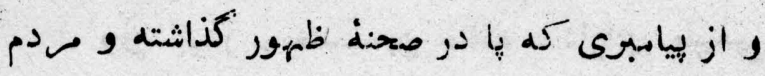

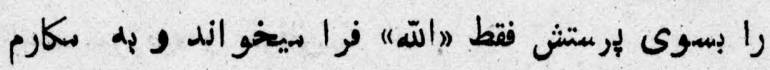

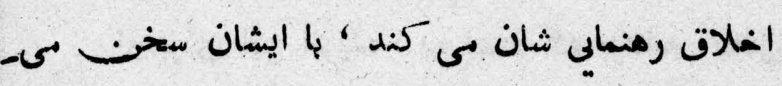
كويد ، و قومش را يكى بي ديكرى به سلى شا كرّدان

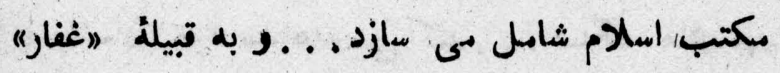

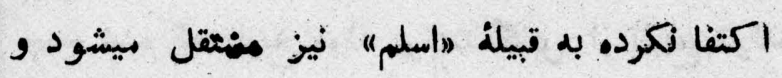

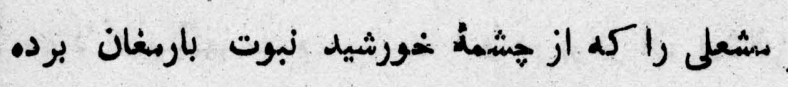

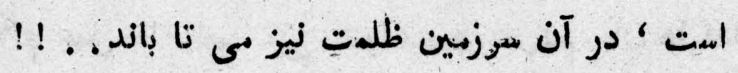

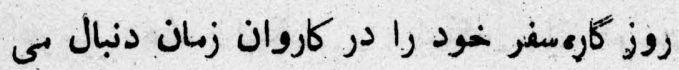

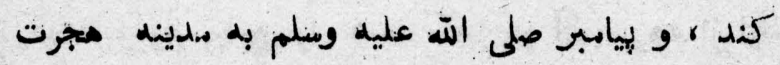

نى نمايد ، و با هنسلعانان در آلجا مستقر منيشود .

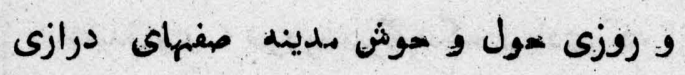

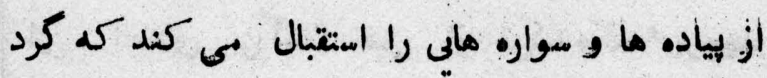

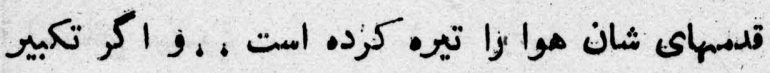

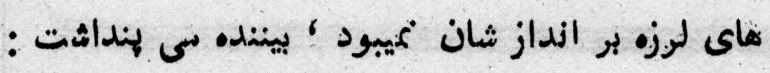

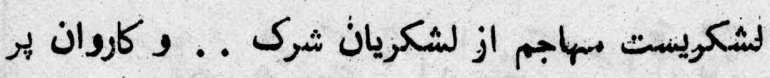

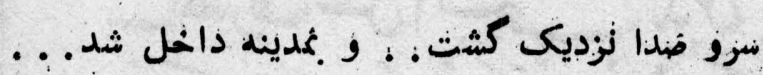

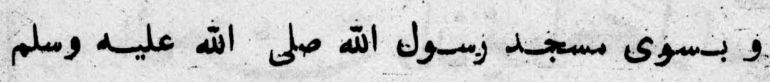
و اقامتكامش روى آورد.

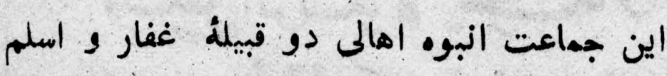

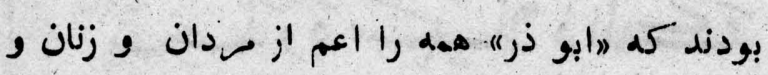

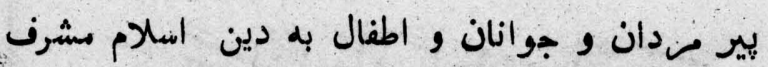
ساغته و بحضور بيانبر صلى اله عليه وصلم آورده

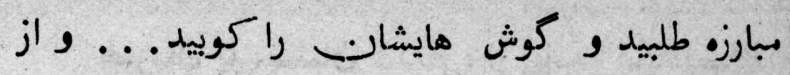

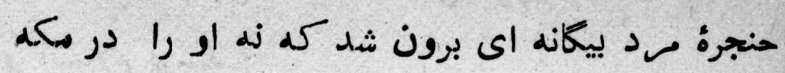
حسبى است ونه نسبى ونه حمايتكرى .

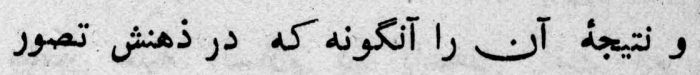
ميكردبديد. . . مشركين احاطه اش نمودند و و آنقدر

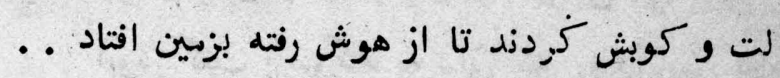

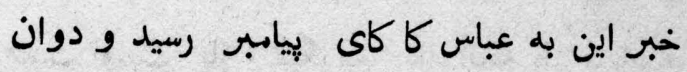

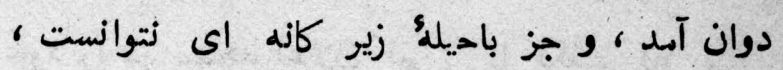

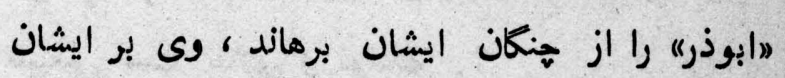

راى كروه تريش • شها تاجرانيد ‘ و راهتان.

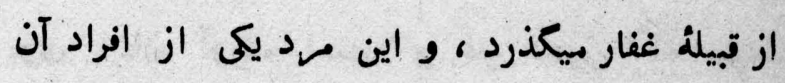

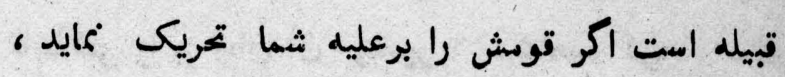

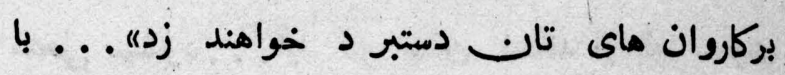
شنيدن اين سخنان عباس ، بخود آندزند و رهايش كردند.

اما ابوذر كه شيرينى .اذيت ديد. لـ در راه.

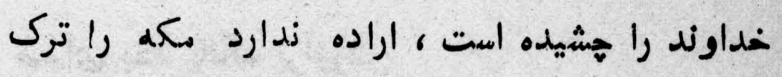
كويد تا آنكه ازين شكرميتان بهرهُ بيشترى بردارد ه . .

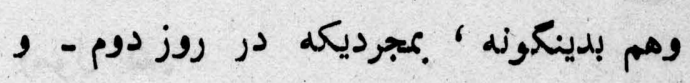

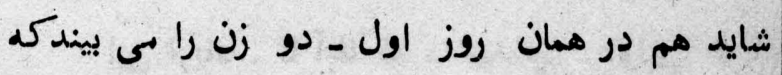

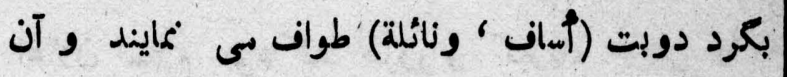

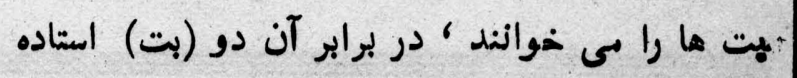

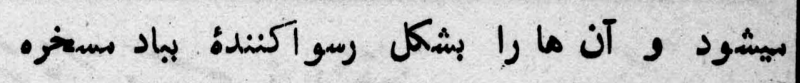
مى كيد باديدن ايــ حال آن دوزن فرياد مى كشند و مسد ها همجيون ملخخ برسرش (ابوذر) فرونى ريزند

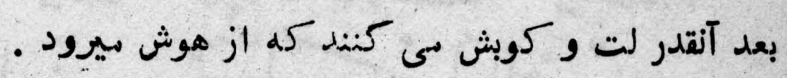
و هنكانيكه بهوش مى آيد ، بار ديكر فرياد

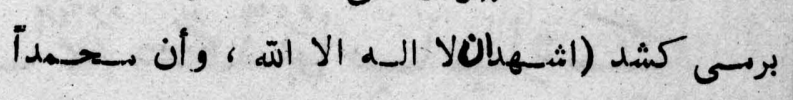
رسول الة).

بيامبر صلى اله عليه وسلم طبيعت شاكرد جديد 
آرى. . بزودى اجر فراوان و تحسييتـ مباركى

نصيبش خواهند شد . .

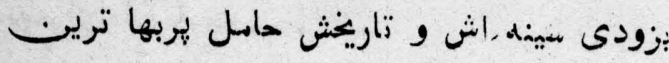

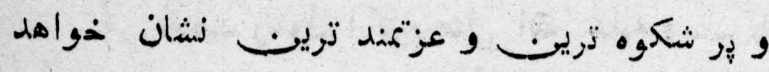

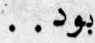

بزودى قرنها و زسلمل ها بباد فنا خواهند رفت

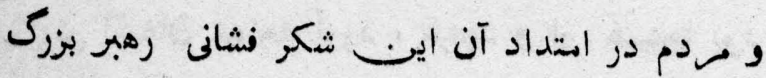

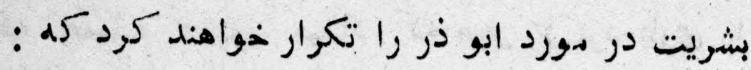

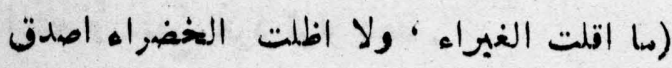

$$
\text { لهجة من ابى ذر) ...! }
$$

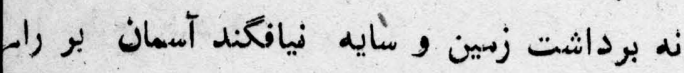

$$
\text { ستكو تر و صريح اللهجه ترى از ابو ذر. . . }
$$

بدون شك بيامبر عليه الصالاة والسلام آيندة

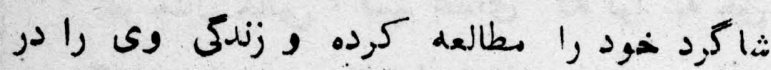

$$
\text { كمات فوق خلاصه نمودد . . }
$$

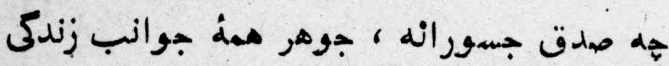

$$
\text { ابو ذر است .. }
$$

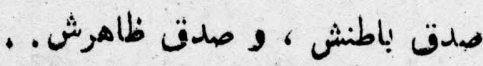
صدق عقيده اش ، و صدق لهجه اش .

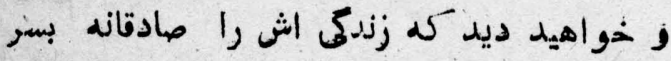

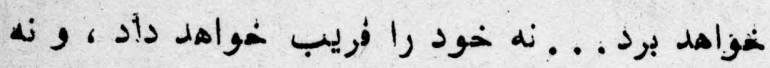

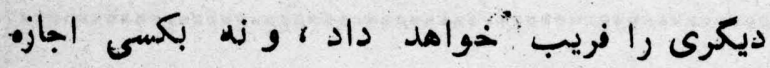

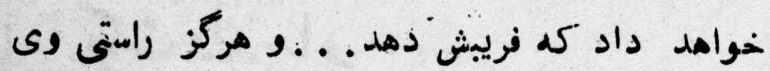

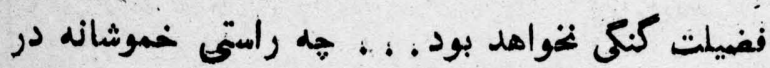

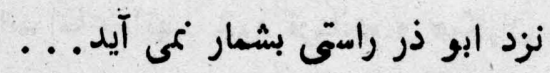

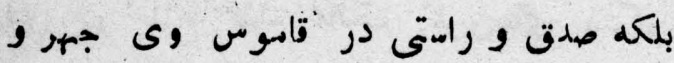

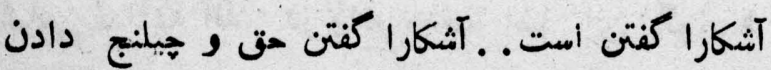

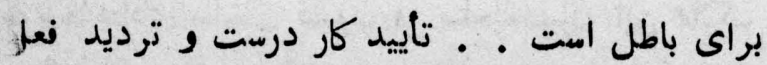

و نبى كريز صلى اله عليه وسلم حق داشت به تعجب و حيرت خود بيافزايد . .

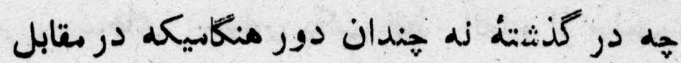

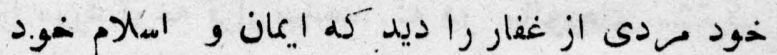

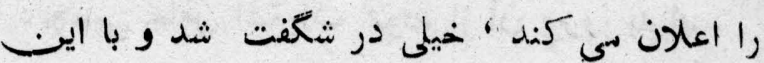

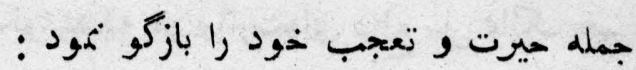

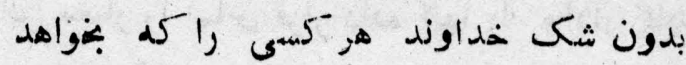
هدايت مى كند :

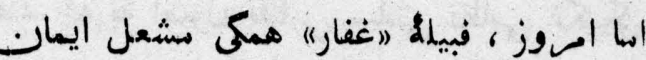
بركف به حضورش مشرف ميشوند . . . و از وتتيكه

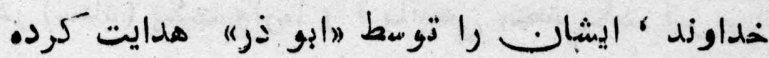

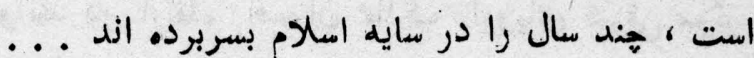
و با آن ها قبيله اسلم نيز آمده است.

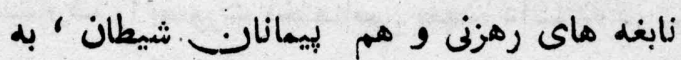

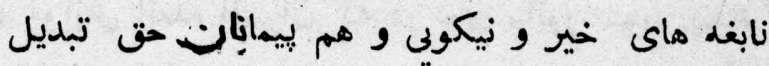
شده اند.

آيا نه جهنان است كه بدون شكى ، خداوند هر

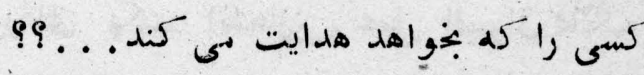

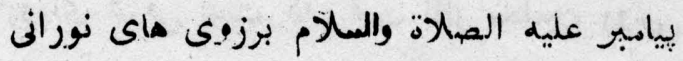

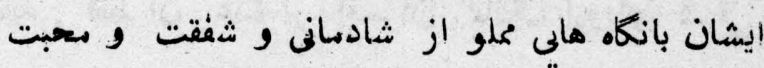
. . . مي

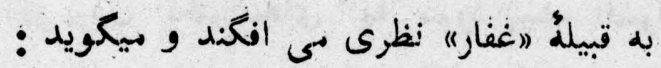

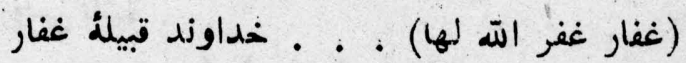

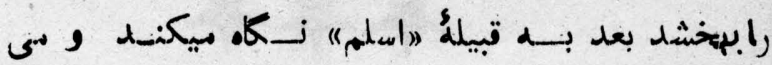
فروايد : (واسلم سالمها اله) ... . و خداوند قبيلهُ اسلمم

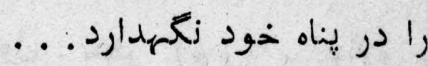

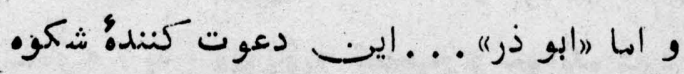
هند . . . سر سخت ، كم زنظير . . آيا بيانبر عليه العلاة والسلام با تحسينى سر فرازش نميسازد . .؟؟ 
يكى از لمعيارهاى ارتقاء صاحبمنصبان مانكى

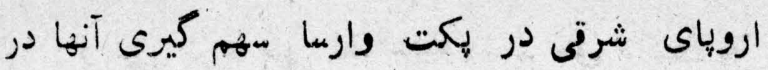

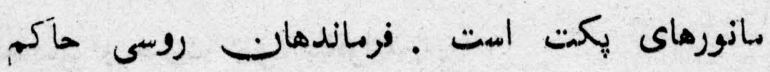

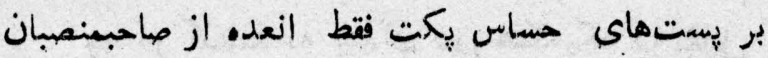

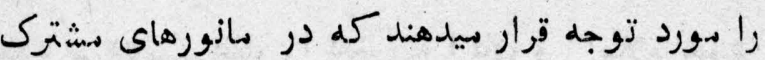
با دلجهيهى خاص اشتراك نموده از آن بيروز بدرايند .

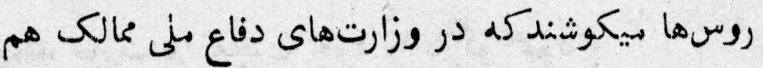

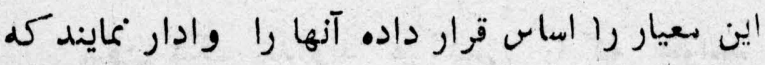

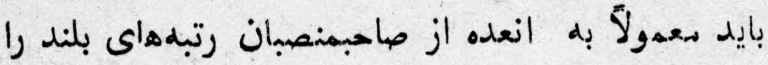
بدهند كه بذ اصول نظامى سياسى نظاسى تكتيكى بكت

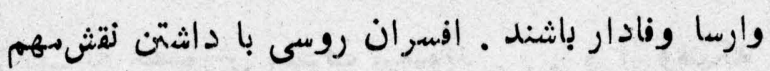

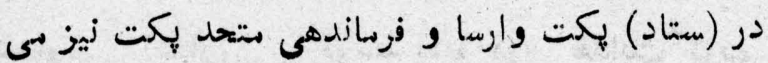

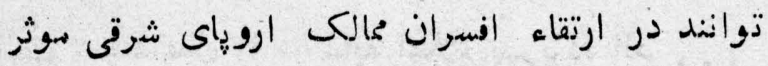

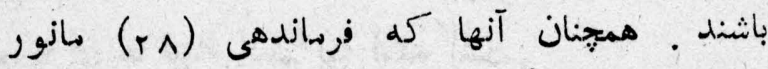
مشترك را بصورت اختصاصى بعهده داثتنده در مرورش

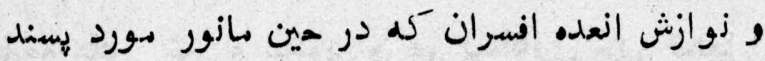
شان بوده تاثير دارند و سعى بى ورزند كه آنها را لهان

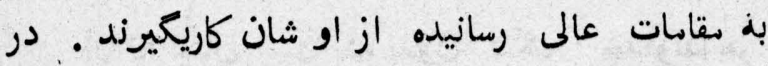

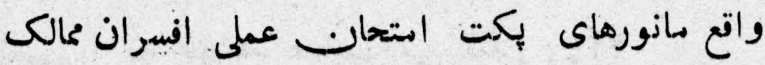
اروباى شرقى است كه تحت نظر معلمين روسى انجام

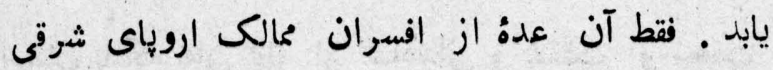
هيتوانند به درجههاى يختلف ارتقاه 'نمايند كه طرز كار

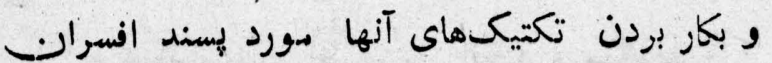

$$
\begin{aligned}
& \text { زوسى باثد . } \\
& M Y M
\end{aligned}
$$

تصنيع ضرورى :

در شمارة ههارم (ثمارة قبلى) ايز مجله - دز

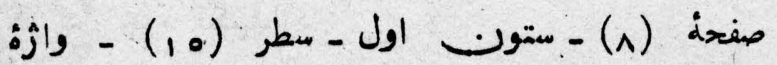

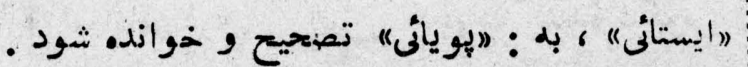
(اروار )
"راستى" إشتيبانى مردانه ازحق ، و تعبير دلاورانه از آتــ است ، و مهسفرى تند و هابكانه بهمراى آن است...

در هقيقت رسول اكرم صلى الته عليه وسام با بان

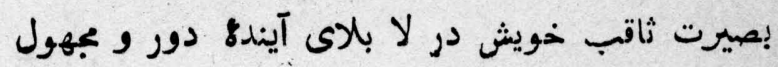

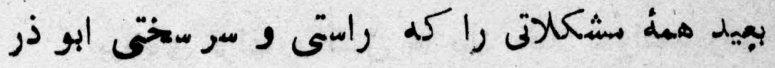

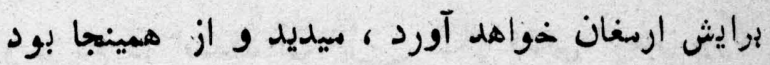

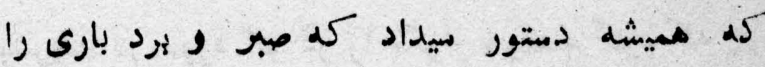

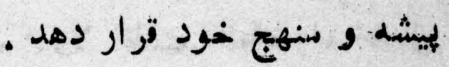

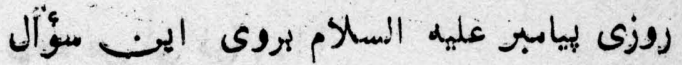

$$
\text { : المطرع مورى }
$$

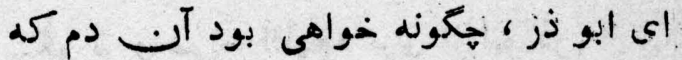

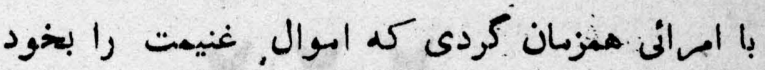
اختصاص نى دهند). . .

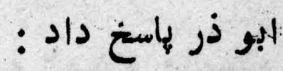

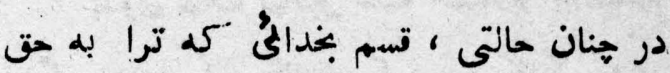
بر انكيخته است ، حتما با شمشير خود هواهم !!... (م)

بياسبر اكرم صلى الهه عليه وسلم براى وى ك5:

(آيا بر عكس العملى بهتر ازيــ ترا رهنهانى کكنم ....

(باتق

\section{... م}

شرقى انجام دادهاند اما با انهم خود فرمانده و همكران

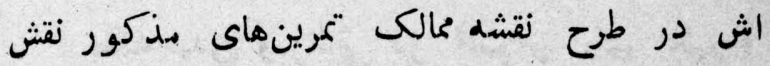

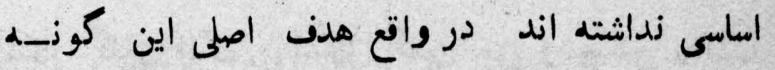

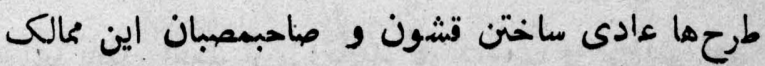
دمر تُبول فرماندهى فرماندهان غير ملى است . 
عيسى محته عصست تانع
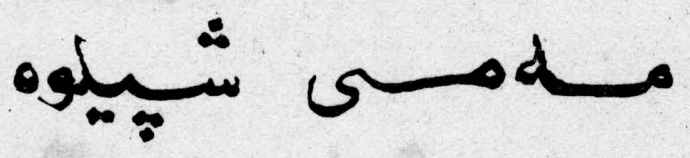

اوس هي مطاغه بنراله نازنين دلوى افغان دننك شمله خرخدكر.

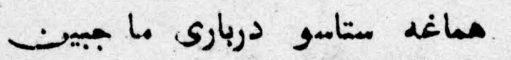

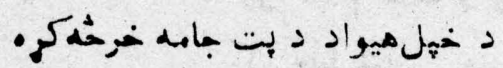

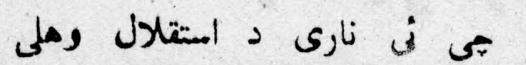

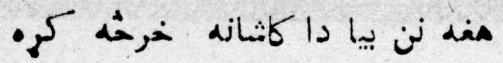

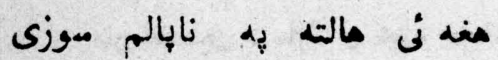

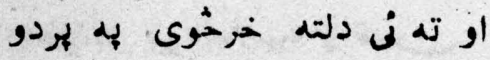
دغه مظلوم دغه بيوزله ملت

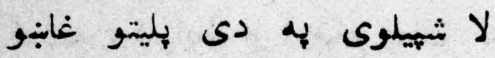

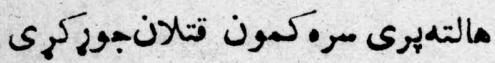

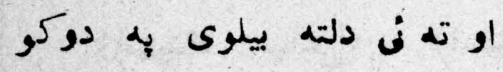
لي خه حيا او لبر خده شرم وكر اله

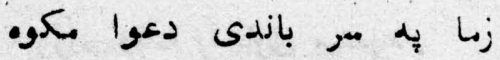
زما دد درد او دمبا بهراسب عامله

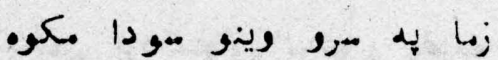

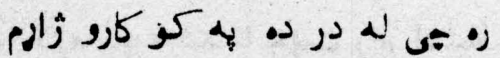

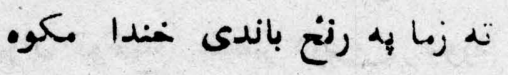

نواى له درباره شرل شوى اخا بس ده مدوكى مى نور مه ثه ثريهلو ها دخهل دين او وطن غمته برييده.

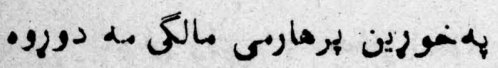

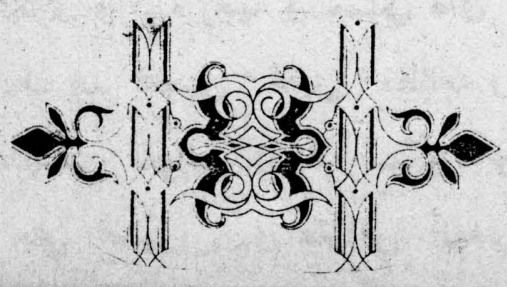

اى لد درباره شرل شوى آغأ

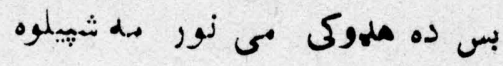
ما دخهل دين ار وطنغمته بريزد.

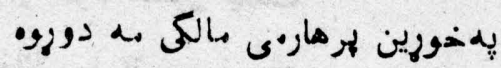
هلته خو مم سيتا با دارى هليده زه دى شرير او تخريب كار كثلم

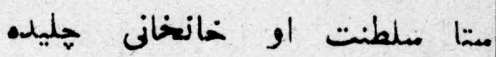

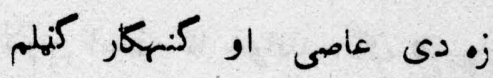

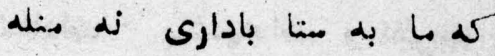
تا به باغى او غت اله اثرار كنلم

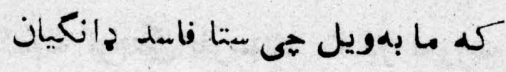
يوه ورخ زما كور او وطن خرخوى

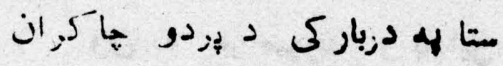

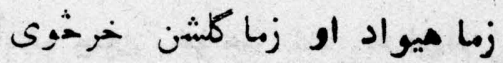

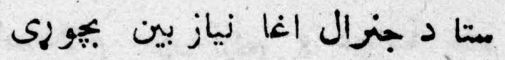

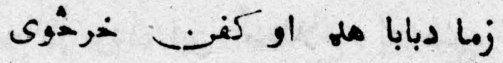
تا به ويل هى ليونتوب مكوه كه نه زه خيلخروري بـهياندرشهم كه دى له بلى بانلاخولى سون وكاوه

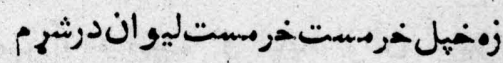
هیى زه دزبارى خرقه يوثالـ درى شهم

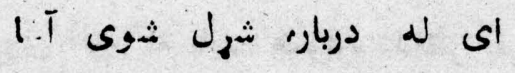
بس ده مهوكى مى نور مله ثهيمون

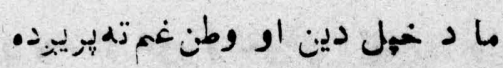

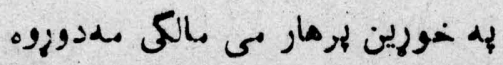




\section{7}

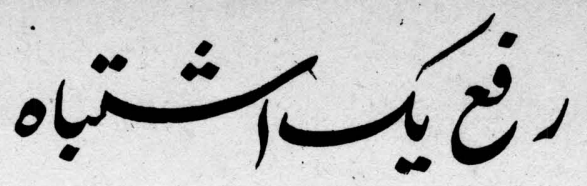

شرايف اله فقيرى

\section{|- |-}

هر كلغم صاف و زوثن در خود تغسير نيست

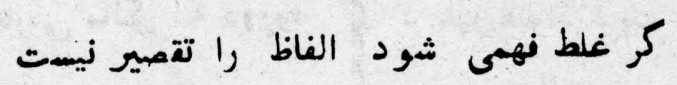

\section{\.}

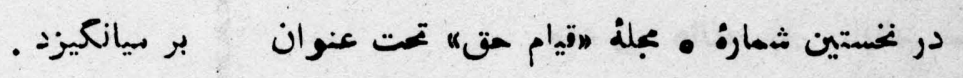

كرخه اصولا لازم است تا خواننده كان متترم

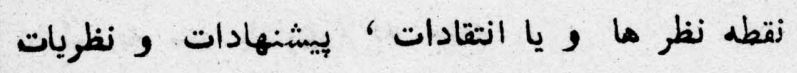
خود را بصورت خصوصى و كتبى به آهريت نشرات

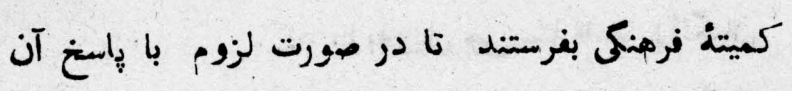

$$
\text { نشر كردد. }
$$

ولى بد مر صورت و با اين اميدوارى كه در

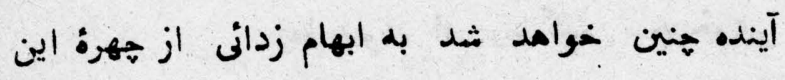

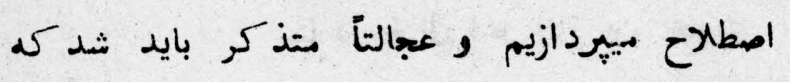

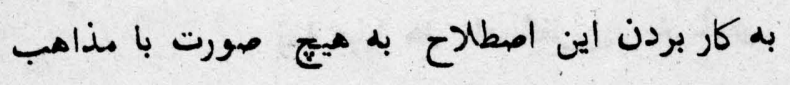
دين بين اسلام ارتباط نذاثته .

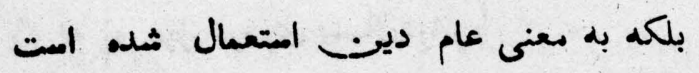
طوريكه معبولا بصورت مذمب اسلام" عيسويت وغير.

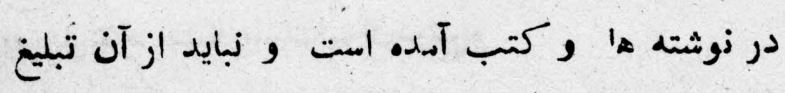

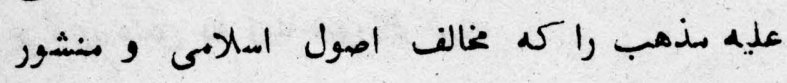

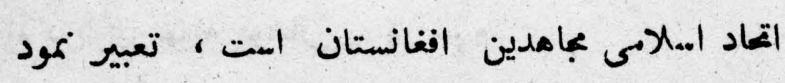

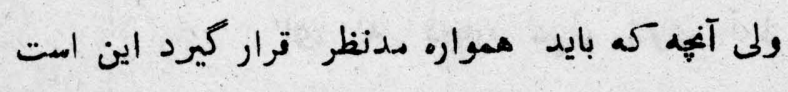

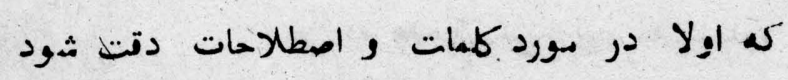

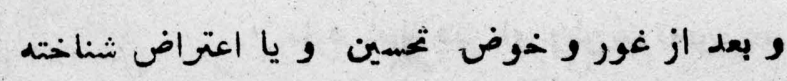

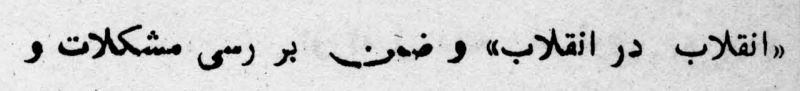

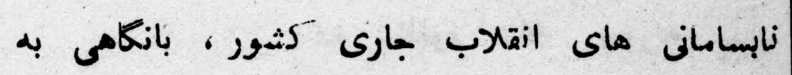

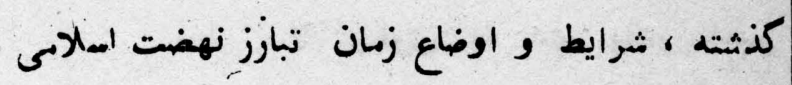

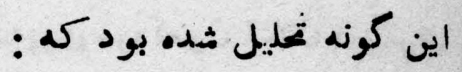

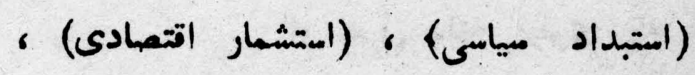

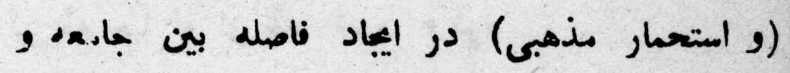

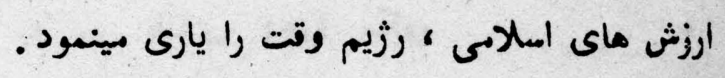

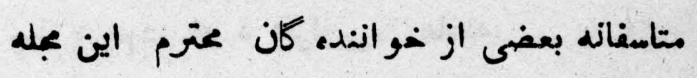

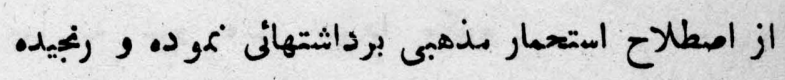

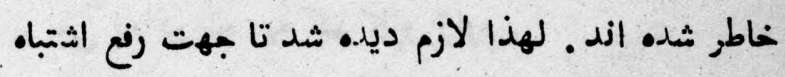

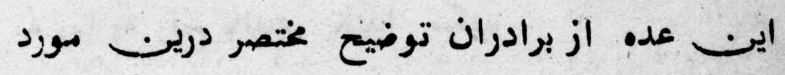

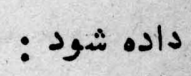
اولا بايد متذكر شد كم براى آمسيت نشرات

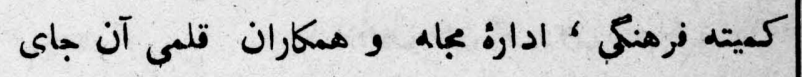

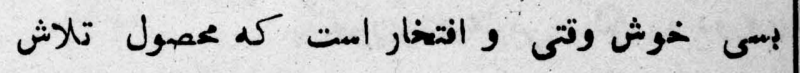

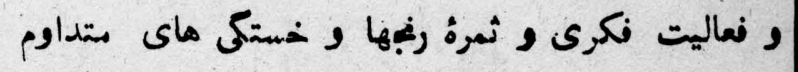

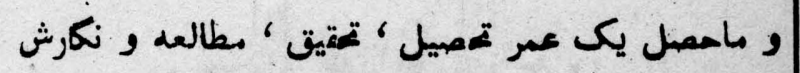

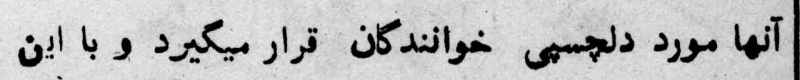

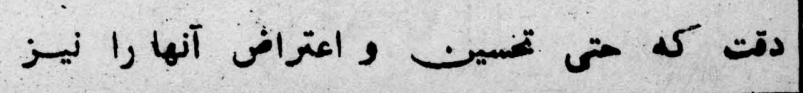


وو در رو قرار دادن جوانان و علماى دين به آسياب دثمن آب ميرختيد ورو مرد

و از ممين جاست كله مغرضين و دشمنان املام

با استناد بل كفته هاى خود. ماغتلة اين عناصر ، اسللم را بباد استهزاء ميكيرند. واقعا ام به معروف و نهى از منكر قرآن كجا و "لعيسى و موشى به دين خودا" استحمار كران كجا.

و "مام تعاليمى كل بنام دين جهت المتحلقار مددم ماخته شده. امت و يا تحريف كرديده و صدها

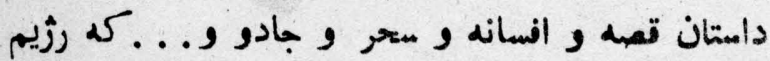

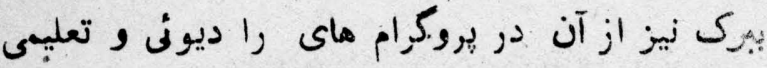
استفاده مينمايد. اين تعاليم را يا دشمنار.ـــاملم ماخته اند و يا ارباب تزوير به نام دين و غاطر دزياى خود و لركردن جيب و شكم خود اختراع كرده إند و يا به غاطط تعبير و تفسير ثده است و مهله

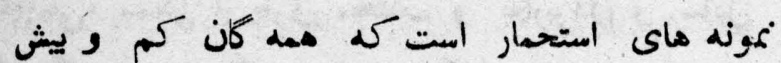
با آن آشنائى دارندم:

و در اخير بايد افزود كم به كواهن تاريخ

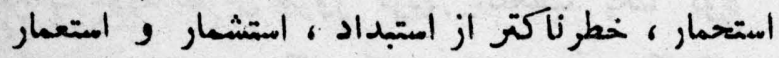
بوده و در برابر دعوت اسلامى بيشترين مقاومت را را نموده است.

اميدوأريم اين عغتعر آن اثثتباه را رفع نموده. prontlo

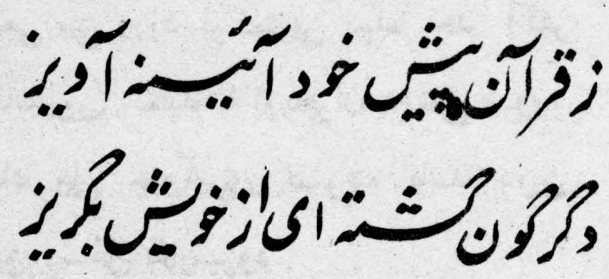

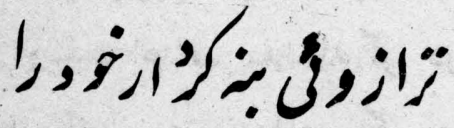

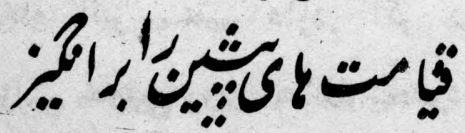

(آبال)

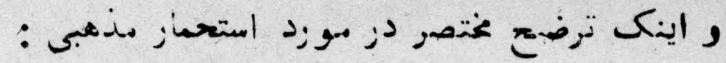

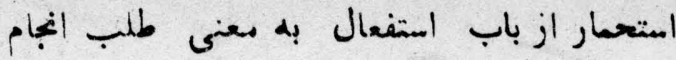

كر و استعملار به معنى خزماختّن و قيد مذهبى يعنى مددم را از طريق مذهب سوارى) كردن. و درجوامع

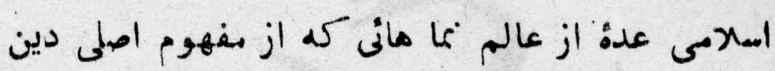
نا واتت بودند و يا اكر واقف هم بودند، حرص مال و متاء زندكى دنيا :زر آنها غلبه كرده. و :ين رادر

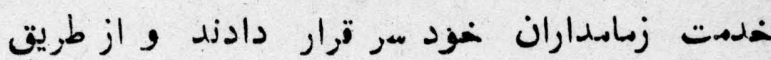
مذهب و دين به اغواء و فريب مردم إيرداغتمند

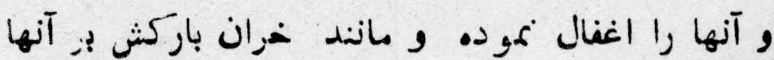

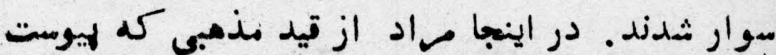

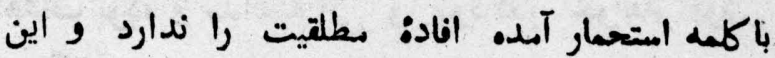
براى عكوميت مذمب نيست ، بلكه براى اقامن دعوى عليه كسانيست كله از مذمب سوء استفاده ميبرند و دين را دو توجيه اعمال نارواى زمامداران ضهد اسلامى و خود كمه به استفاده ميكذارند. مانند كسانيكه به نفع رزيم فاسهد و ضد اسلامى مدلطنتى علماى عاهد املكام را كله عليه كفر ، كمونيزم ثراب خوارى و. .. . قيام نموده بودند بنام باغى ياد ميكردزند ممجينان تاكيد بر دورى از سياست و اعتقاد بر جدانى دين و مياست و .برهبز از امور دنيوى و كزينش ثيوه رببانيت كار هي كمانى بوده است و

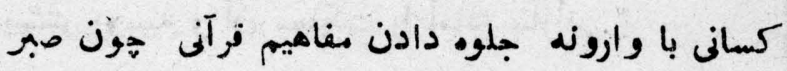
كم به معنى استقامت و شكيبائى امت آنرا دز جهـ رضاء و تسايم در برابر ستم ظالمان و ماكمان توجيه و تقسير مى نموتوند و جه كسانى با استناد نا بها به آيات خدا دشمنان دين غدا را " "ظلل اله في الارضه" معرف مى نمودند و هاسب كرامت هفت وله ميدانستمند

و در شرايط سماس كله ميلاب كفو و ك.ونيزم

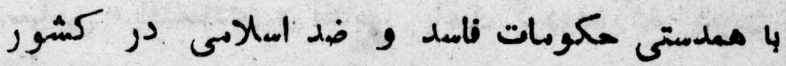
مرا زير شده بود با بزرى مساختن 

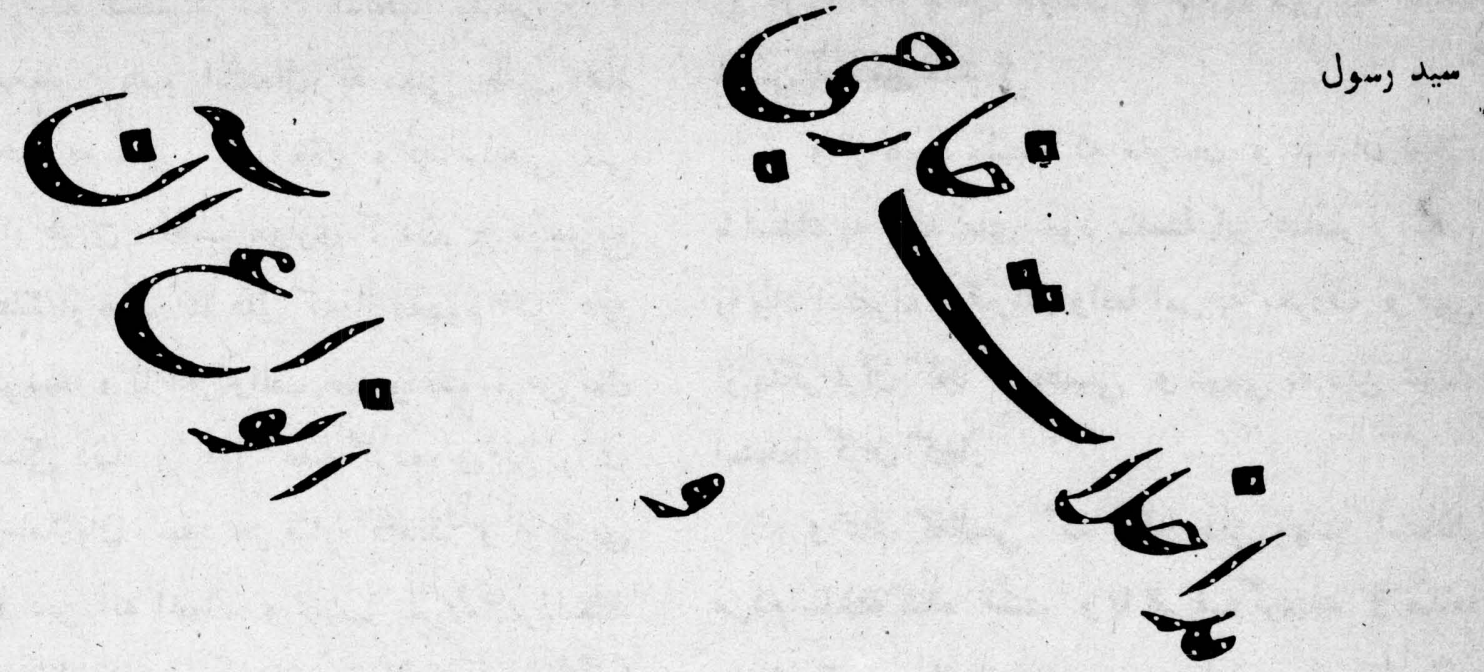

اهداف بوده و مداخلهُ آنى و زودكذز خواهد بود.

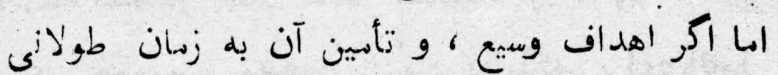

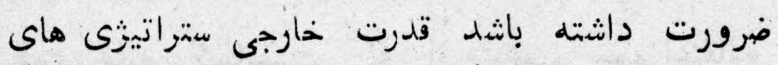

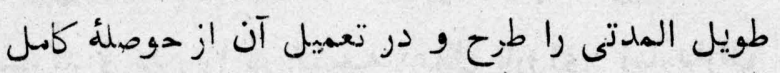

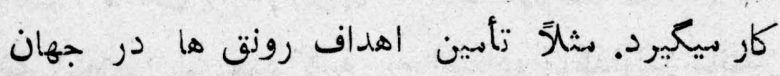

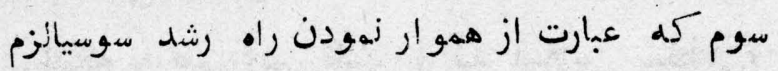
الست به ستراتيزى خاصى ضرورت دارد و مسداخلات

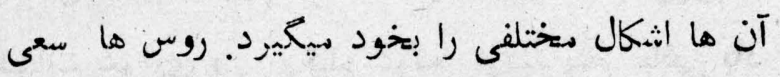

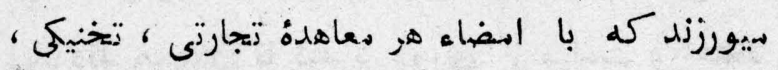
و نظاسى يرسونل كافى در مملكت طرف مقابل بفرستيند

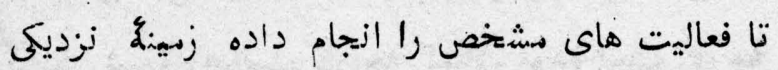
بيشتر روسيه و آن مملكت را آساد. سازند.

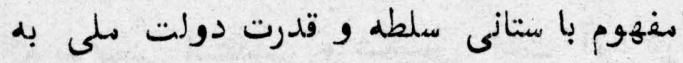

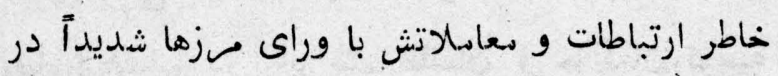

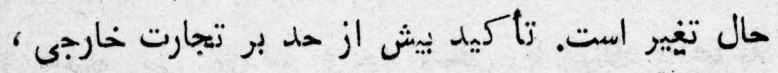

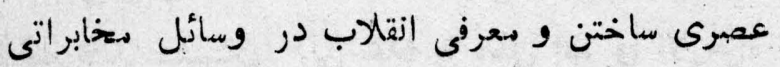
و حمل و نقل ، وسعت قدرت خارق العادة سلاح

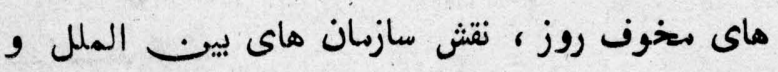

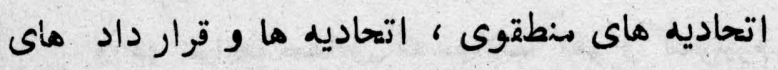

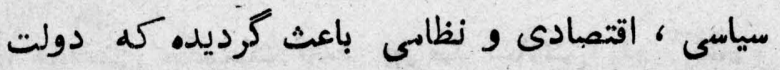
ها در معرض مداخلات كوناكون خارجى قرار كيرند.
صنف بندى مداخلات خارجى به انواع فوق بله

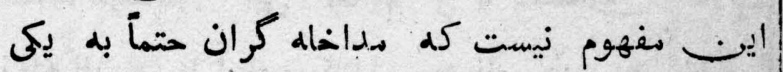

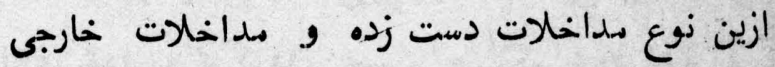

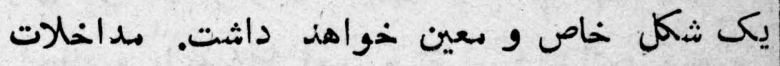
خارجى، ممكن از طرق مختلف و بكاربردن و سمائل

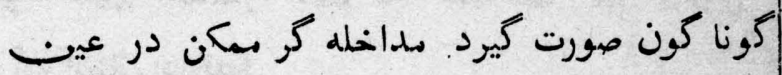

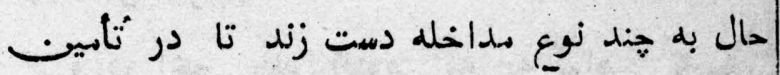

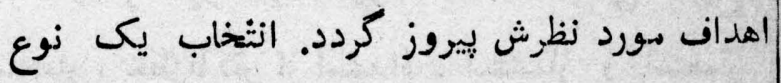

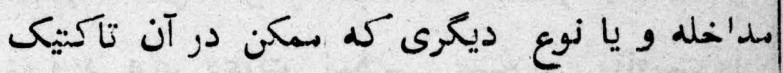
هاي مختلف بكلروود به عو اسل ذيل مسبوط است : 1- بهاه و مفادات مداخله. r- وسعت اهداف مداخخاله كر. r- دورنهاى وسعت نهخالفت ها.

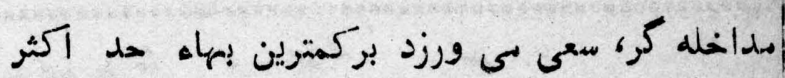

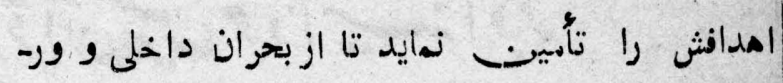

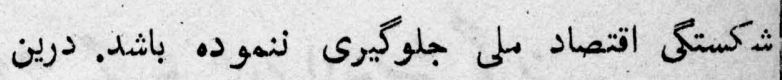
اصورت ارزانترين وسائل بكارمييرود .

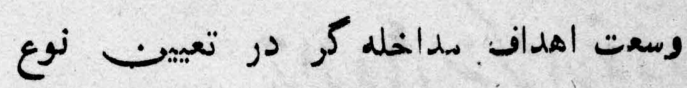

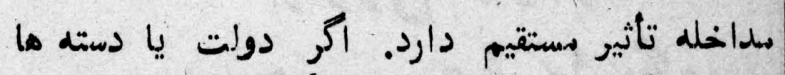

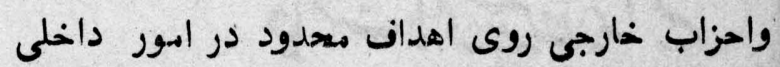

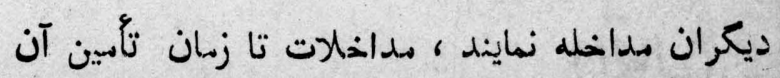


ازجاميد الها اين آزادى ها هنوزثمل واقعى ندارد.

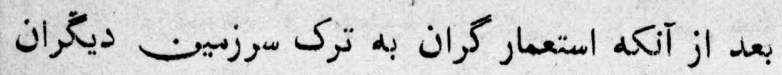

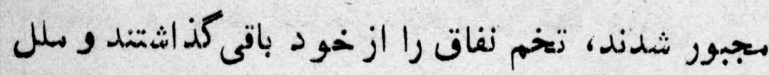

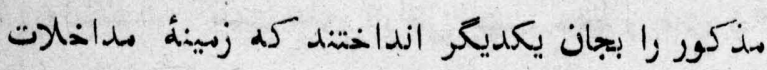

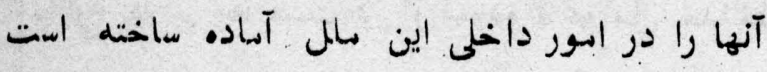

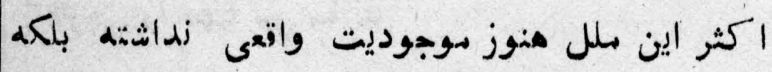

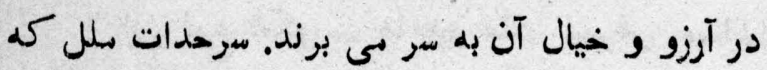

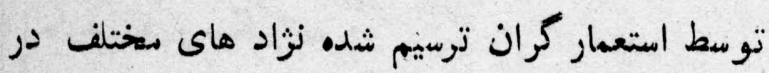

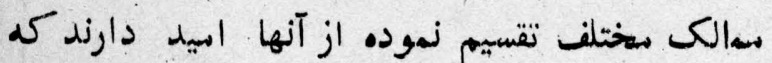

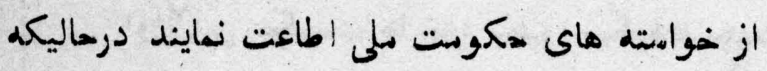

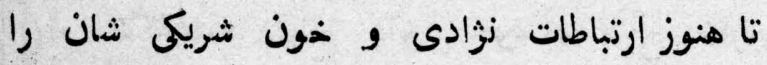

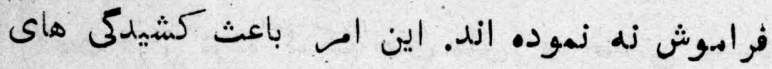

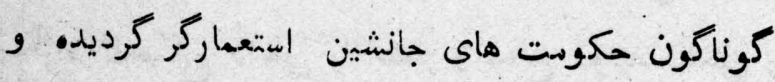
باعث شده كه استعماركران بمداخلات شيان اداده داده داده اهداف سياسى و اقتصادى شان را تأمين زمايند. زد و خوردهاى بلل تازه به استقلال وسيده ، رو.ى سسايل مرحدى معدولا مشكالات اقتعادى و زنظابى در قبال

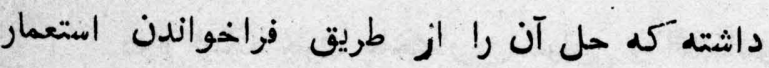
جستجو نموده اند.

آنهه بر مشكلات حكومت هاى امسوزى افزوده

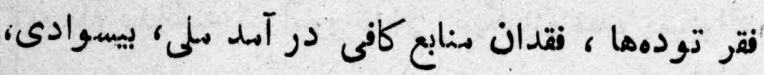

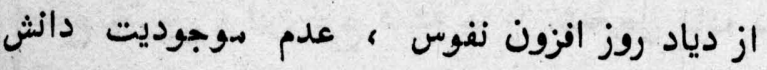

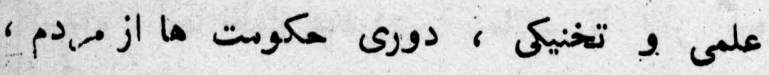

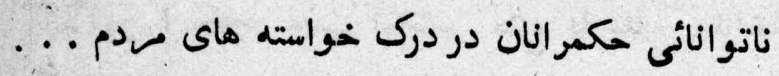

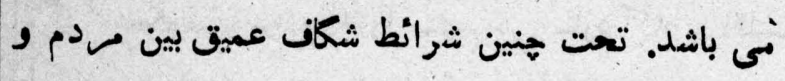

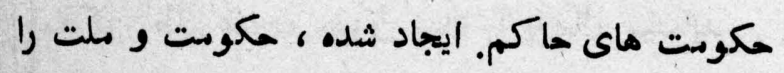

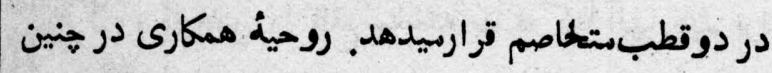

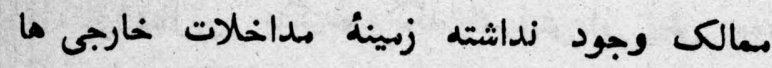
كاملاك مهيا است. اكر مكومت ها ، به اين موضوعات

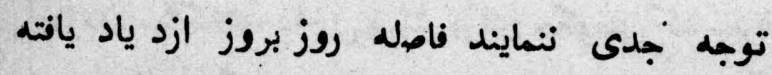

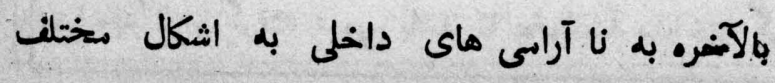

جان هرز John Herz مى نويسد كم : نفوذ نايذيرى

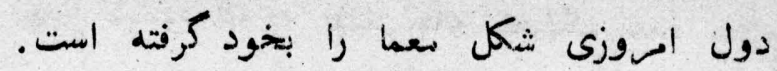

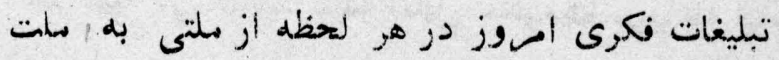

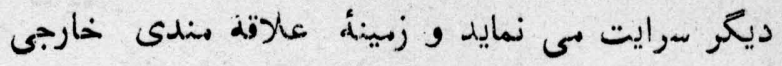

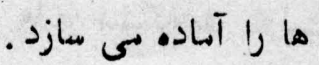
اندريو سكات Andrew Scott مينويسد كه :

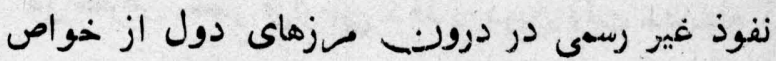

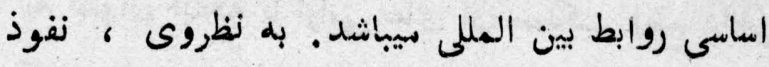

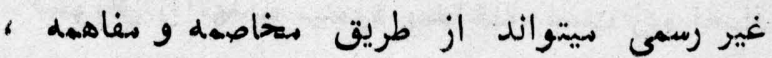

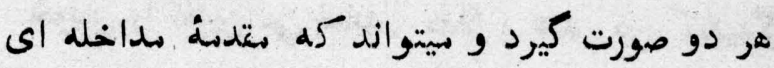

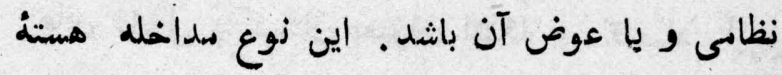

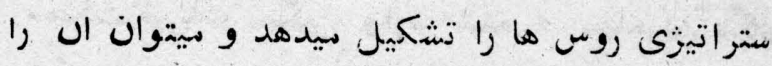

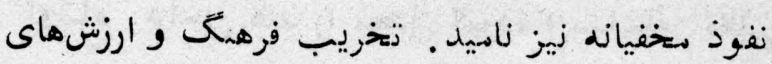

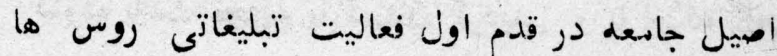

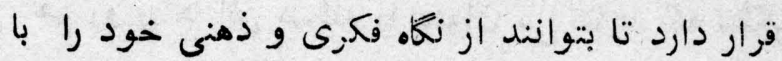

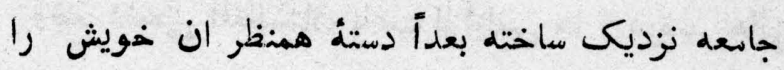

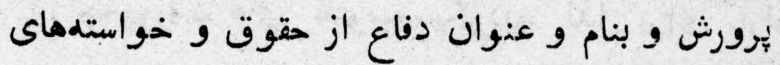

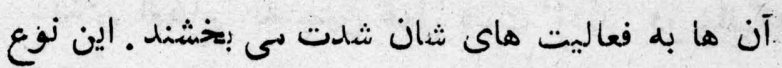

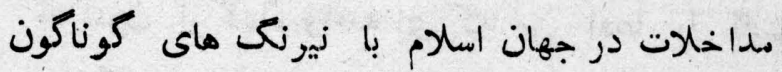

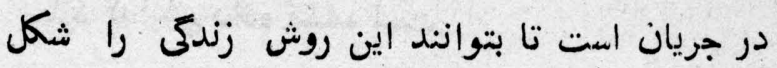
رسوبى دتحض داده قدرت سازندكى آن را نابود نمايند.

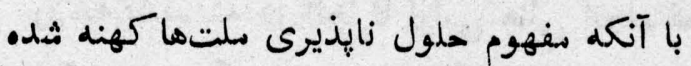

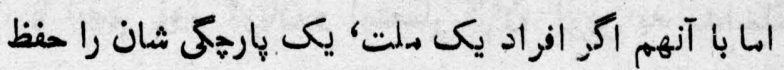

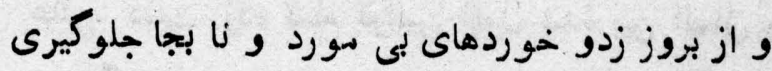

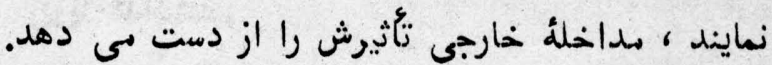

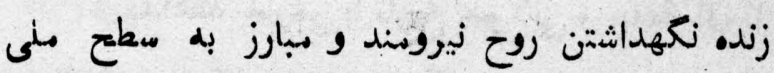

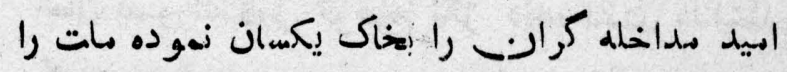

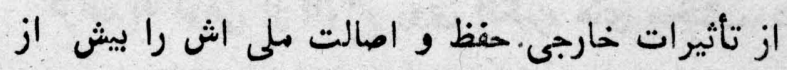
يیش تبارز خواههد داد.

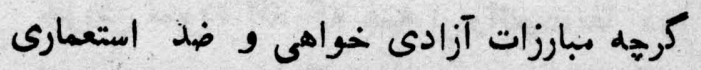
به استقلال تعداد زيادى از مالل آسيائى و إفيقائى 


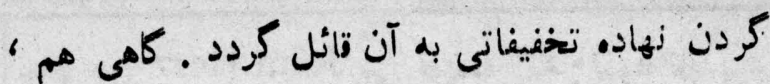

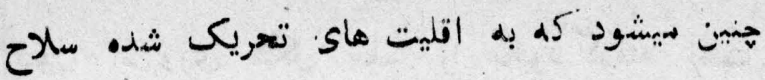

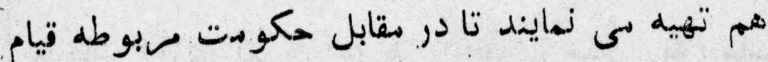
نمايند.

قيام هاى سسلحانه اقليت ما بر مشكلات دولت ها افزوده ساختمان سياسى و اتتصادى آن را بيشتر

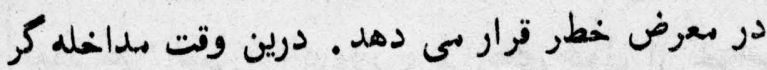

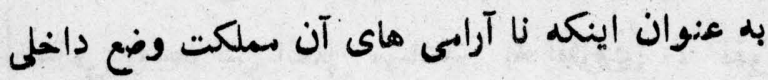
كشورش را تهديد مينمود بهداخله دست زده اهداف لهداف

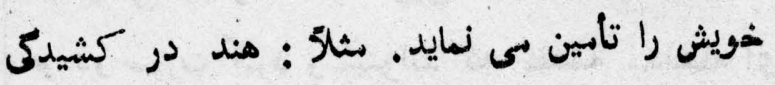

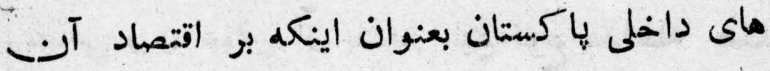

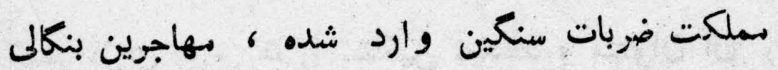

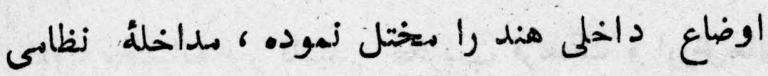

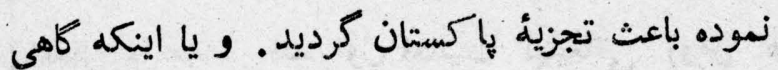
هم روس ها اين مسئله را عنوان مى نمايند كه ممكن

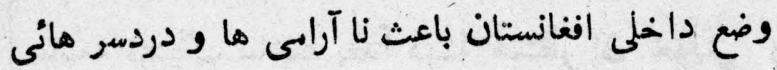
در جمهوريت هاى جنوب ميكرديد لذا براى آرام

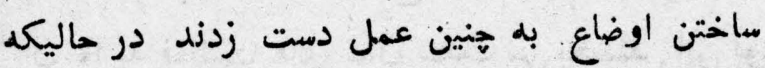

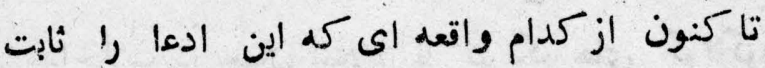
سازد كذارش داده نشده است.

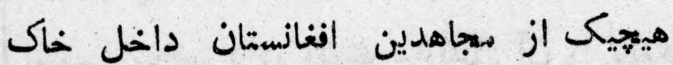

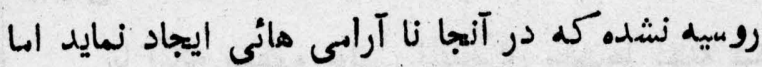

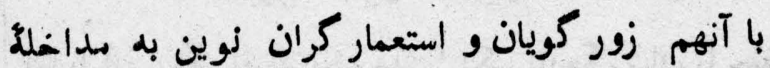
على دمت زده تمام توانين قبول شده بين الملل را لهار زيريا كذاشتيند.

مداخله خارجى با تاريخ طولانى و سابقه آن تا ـ هال بصورت كامل توضيع نكر ديده است. سداخله -

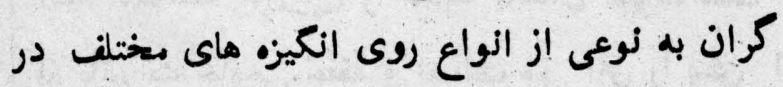

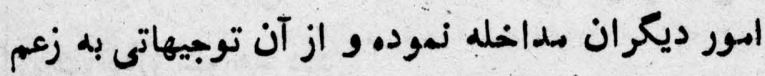

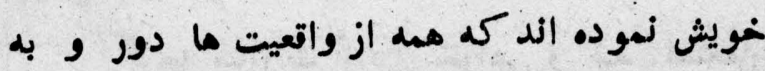

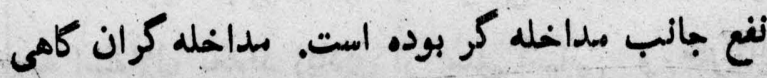

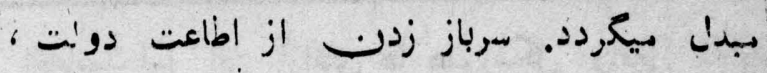

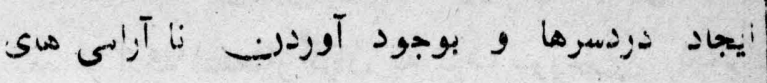

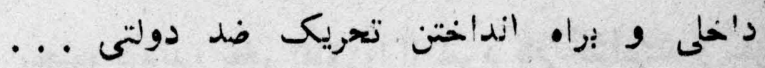
رونما شده، اقليت هاى ناراضى جهت حفظ و بقاى شان

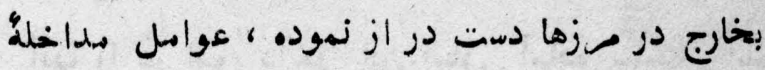
خارجى را سهيا بى سازند. اين نوع هكومت ما بدو علت معرض مداخله خارجى قرار ميكير :ند :

اولآين حكومت ها خود مجبور ميكردند جهت رفع مشكالات و روانع داخلى خود به هنابع خارجى

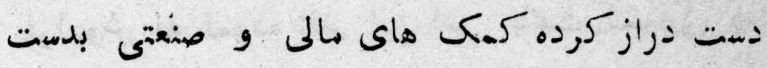

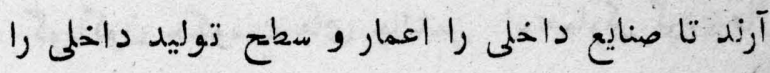
بلند برده درجه بيمرى را تقليل دهند. اين امس خود -

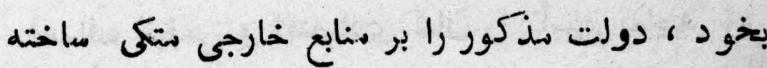

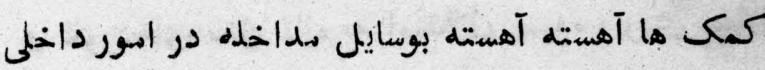
دريافت كنيدة كمك مبدل نيكردد.

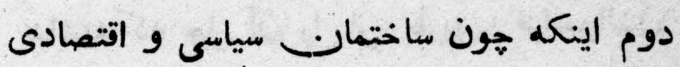

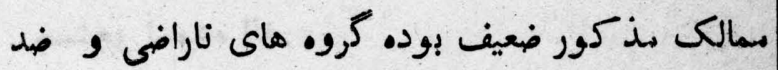

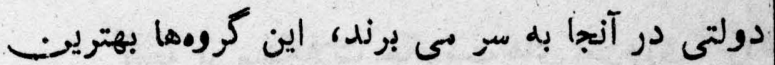

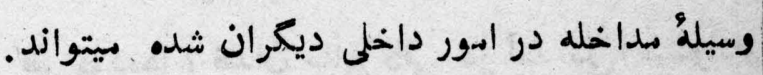

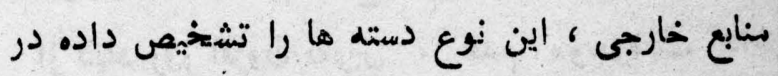

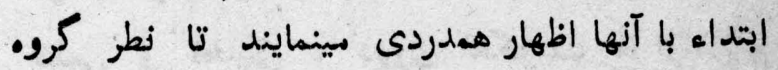

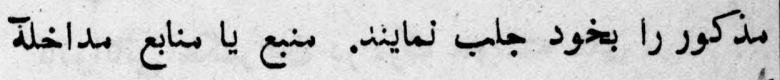

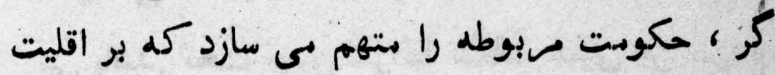

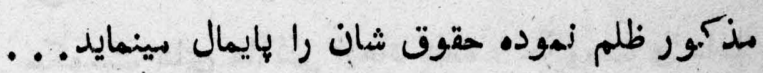

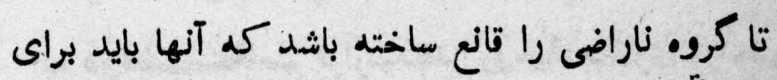

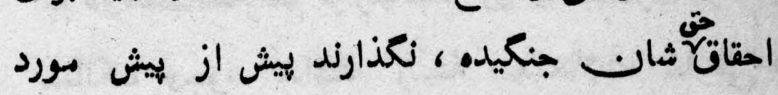

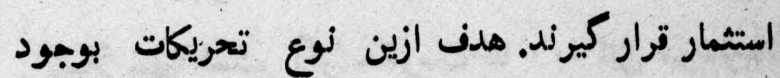

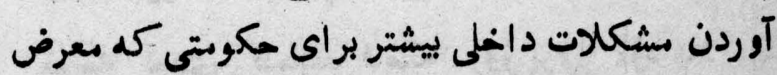
مداخله قرار كرفته ، مى باشد تا بخواسته مداخله كر، 
ايديولوزيكى داشت سياست داخلى روسيه را تهديد

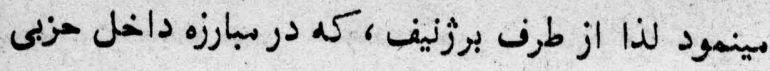

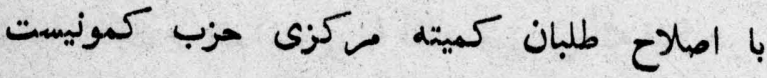

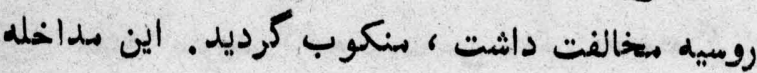

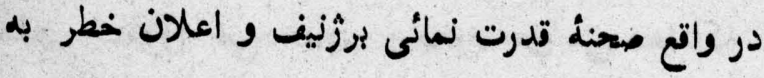

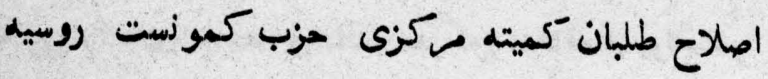
بود كه قدرت شخصى برثنيف را تهديد مى مي نمود.

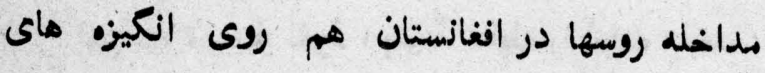
سياسى و تأمين شنافع سلى روسيه صورت كرفت و آنجه

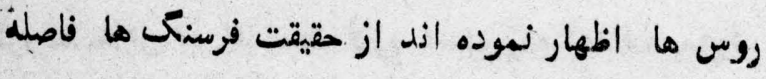
دارد.

يكى از شرائط قبلى مسداخله بوجود آوردن شرائط

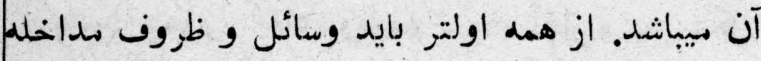

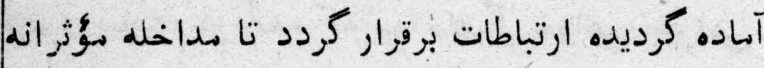

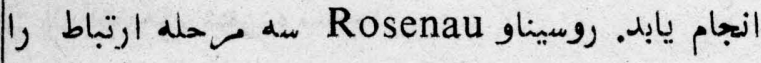

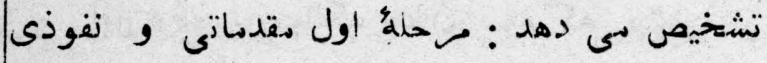

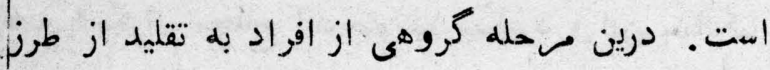

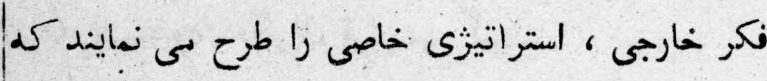

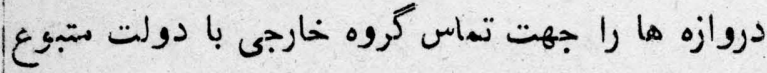

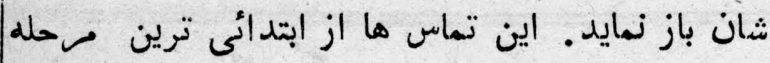

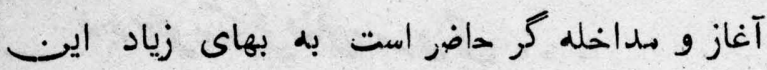

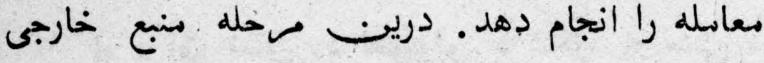

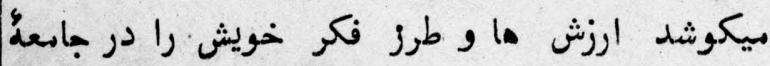
مورد نظر بذر نموده انتظار حاصلات آســ را بكشثد. سحلة دوم آن حالت انعكسى را بخود ميخيرد.

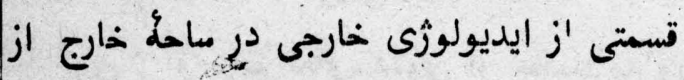

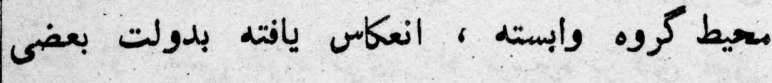

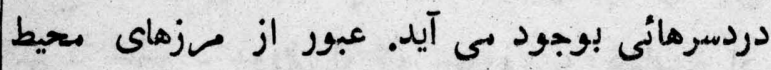

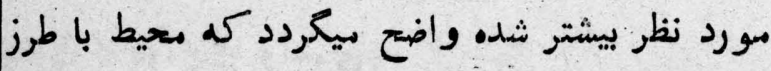

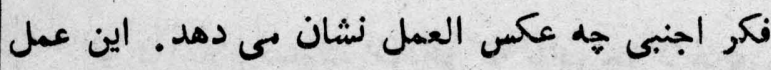
و عكس العمل ها متراتيزى آيندة مداخله كر را لغيين
با فعاليت هاى جندين جانبة قبلى خويش وضع داخلى را

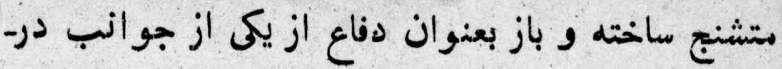
كير ، مداخله نموده است. سداخلات آمريكائى ها در

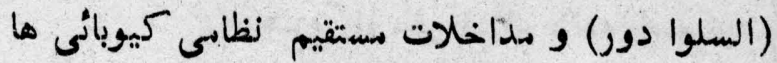
در انكولا و حبشه و مداخلة ويتنام دركمبوديا از نمونه.

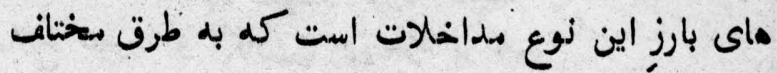
جهت تأمين اهداف خاص سياسى صورت كرفته است. اين نوع هداخلات أز طرف مهالى كمونستى بيشتر

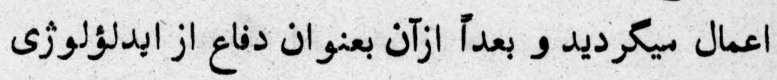
و انجام وظيغه و مكلفيت. أنترناسيوناليستى توجيه

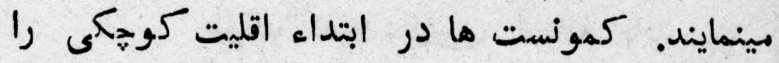

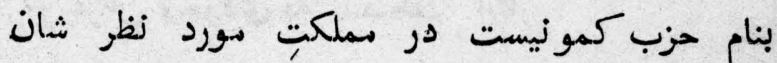
تشكيل و بعدآ در دركيرى هاى آن با دولت ، مداخله نموده از اقليت مذ كور بدفاع ميهردازند.

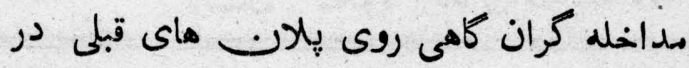

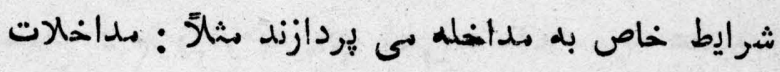

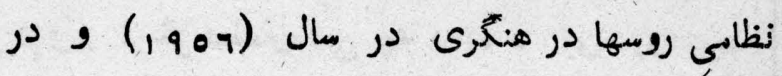

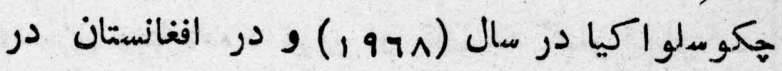

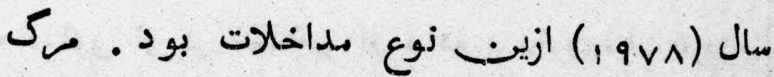

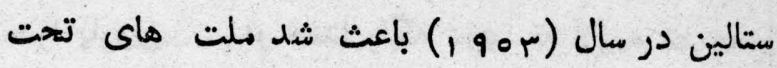

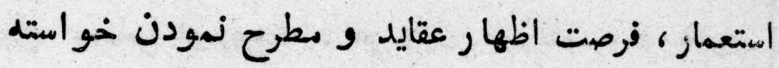

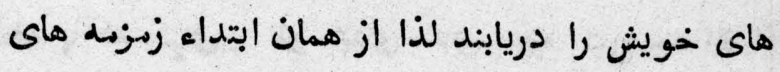

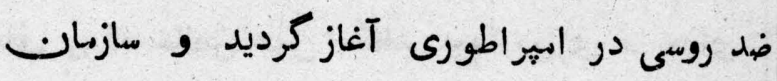
جاسوسى (ك-جي-بى) اين روحيه را دركى نموده در

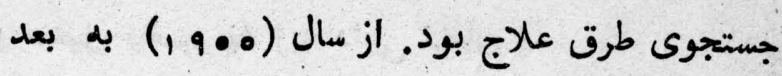

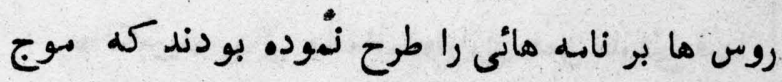

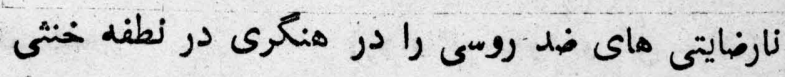

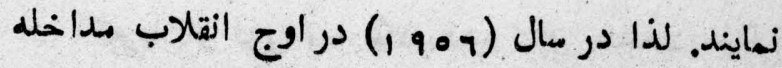

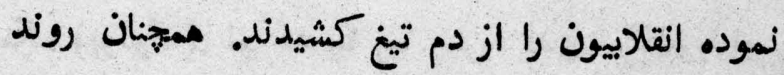

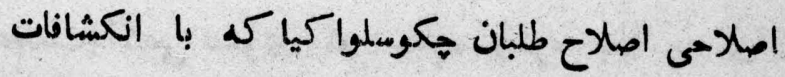
ورويداد هاى داخلى حزب كمونيست روسيه ارتبان ارتباط 


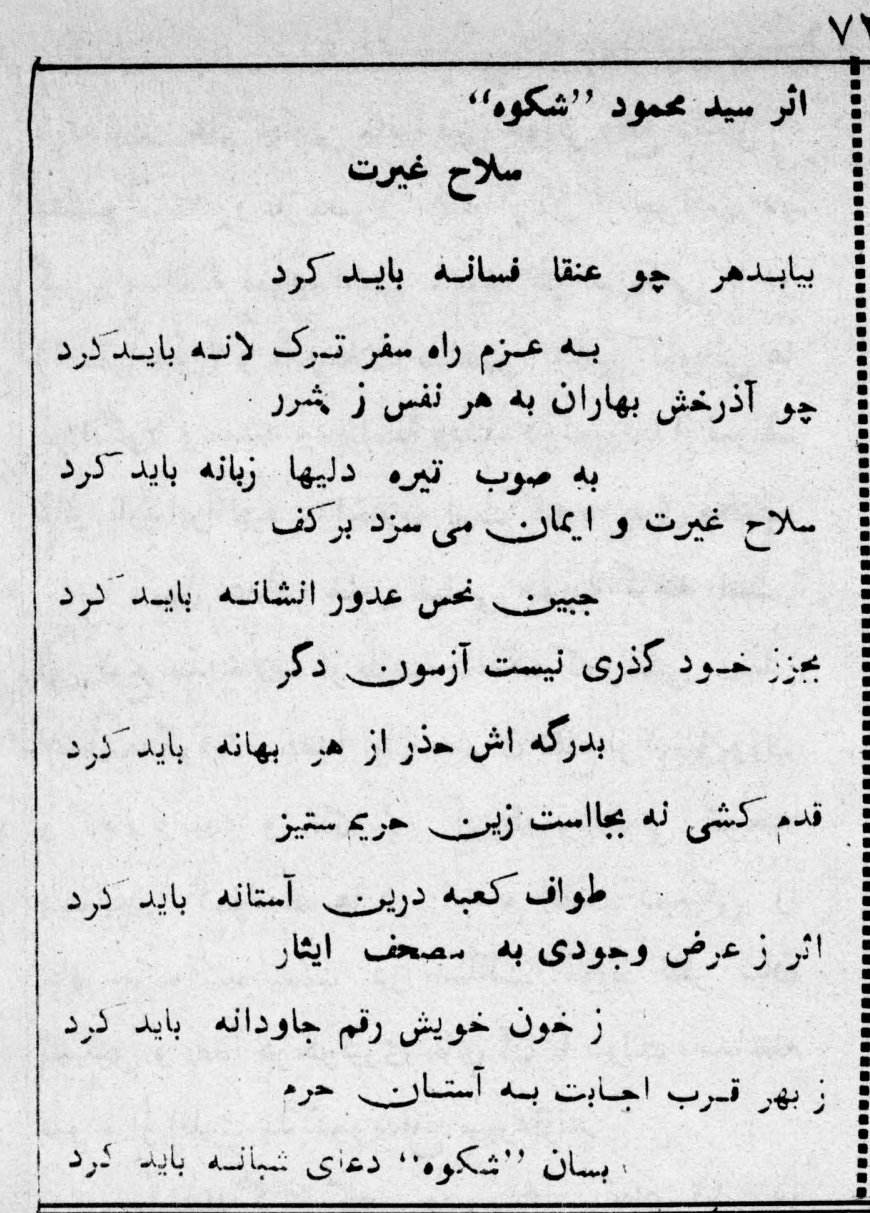

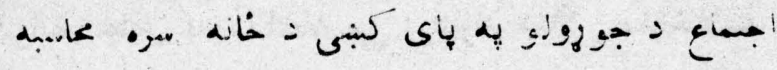

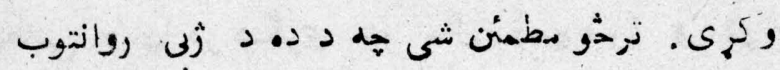

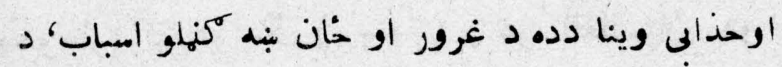

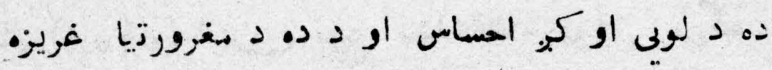

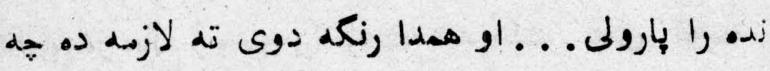
خهل احساس او روحيه د هر ديل نا ولن ولتوب او خيرو

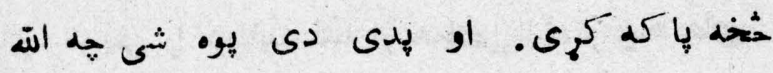

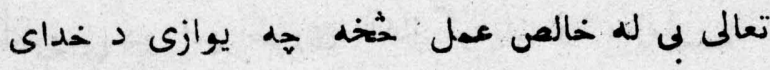

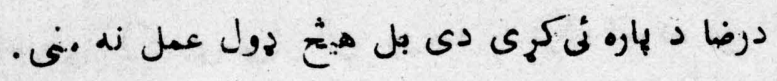

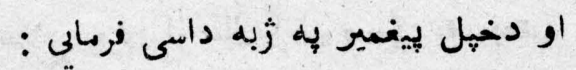

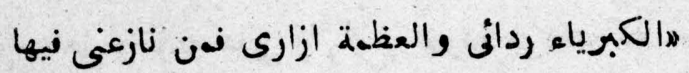

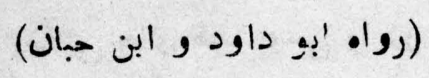

udionas

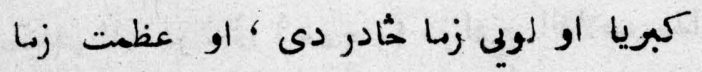

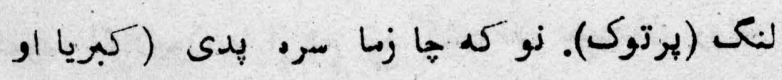

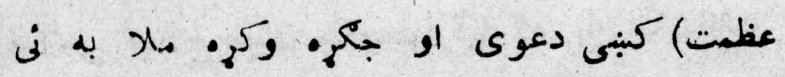
ورناته كرم.

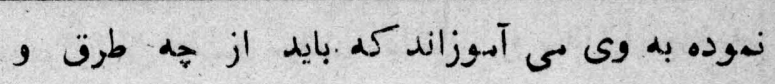

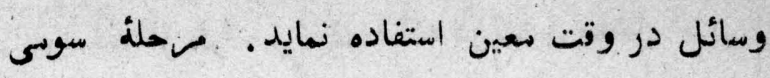

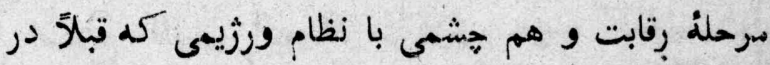

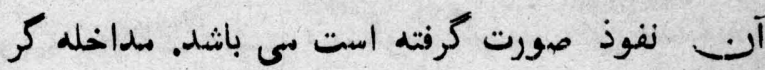

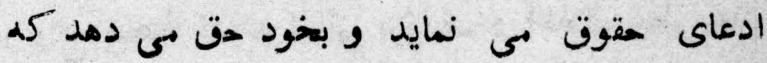

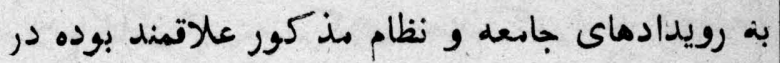
قبال انكشاف آن بى طرف باقى نماند. اين سه مرحله نفوذ ، زمينه سلطه را آماده ساخته

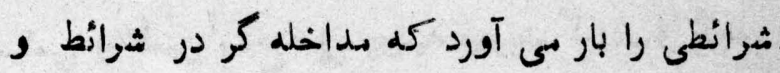

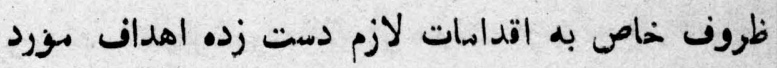

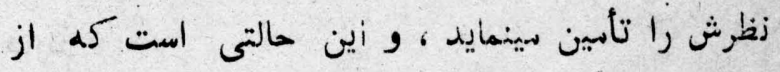

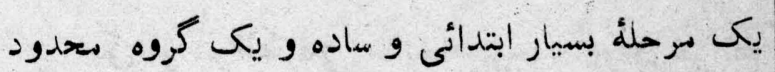

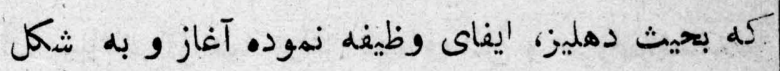

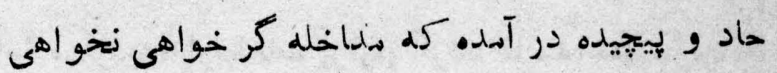
در آن ذيدخل شمر ده بيشود.

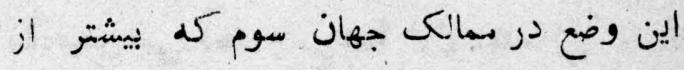

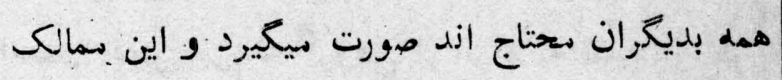
إر معرض نفوذ ديكران قرار مى كيرند.

\section{دوعوتكونَمى روحى...}

او دالته تعالى د نعمثونو د شكر او مننى د

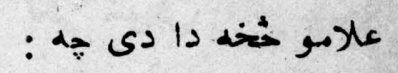

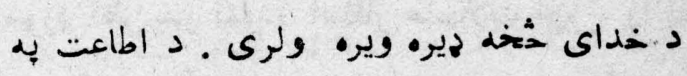

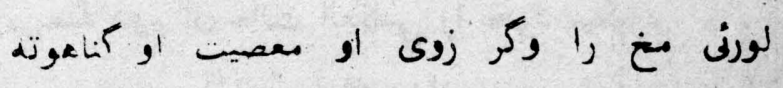

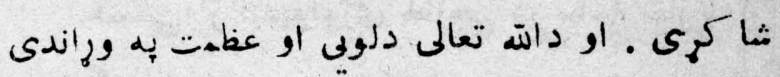

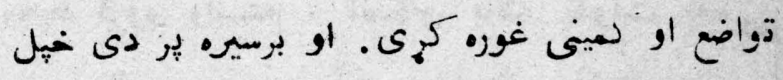

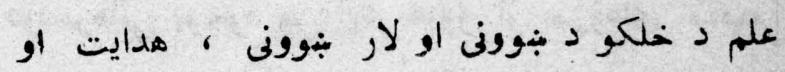
سمون د باره بكار واجوى.

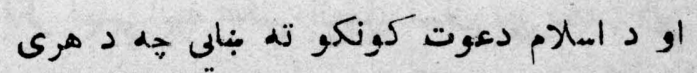
وينا او بيانى دايراد ، او د مقالى خ ليكو ، او د 
شهرت لنعيال
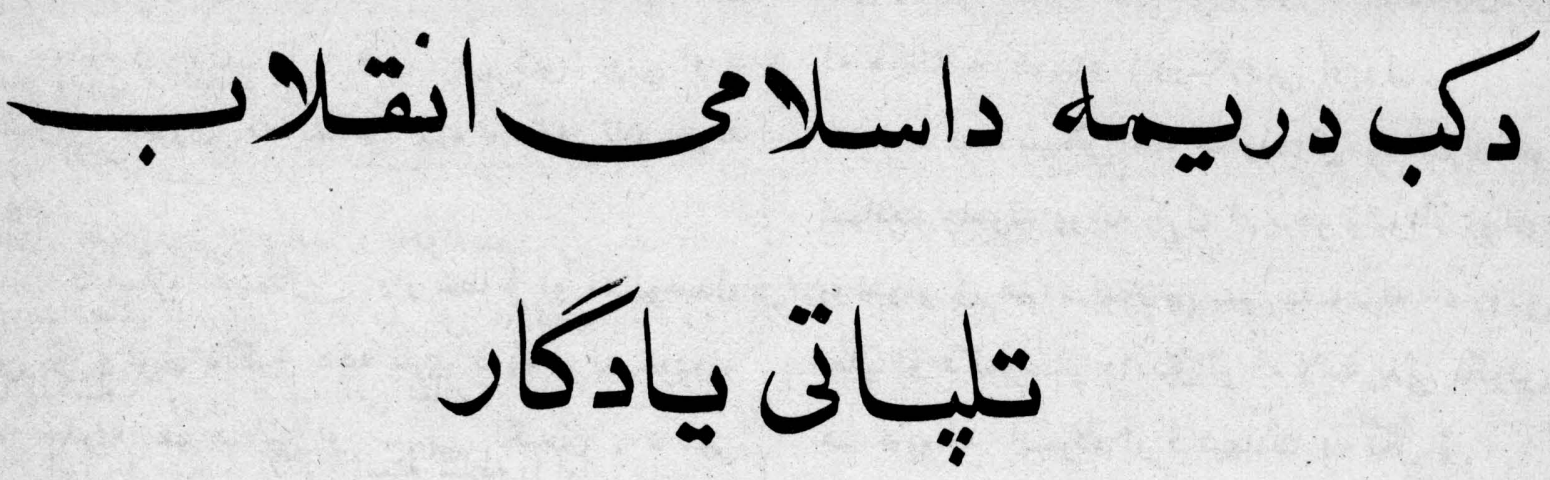

د كبل بنار منظر. او بنه هسى الوتى به نظر كابل بنار به فضاكى زمزمه كيدلى.

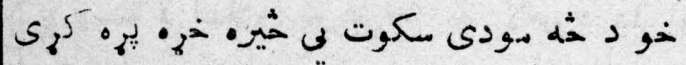

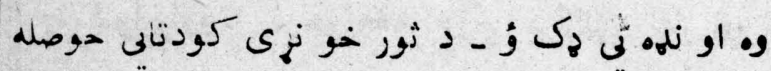

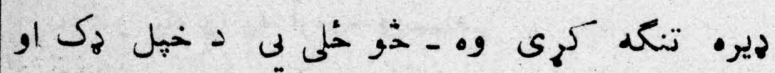

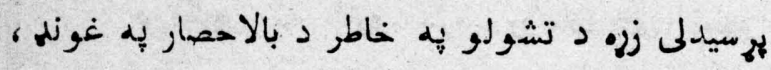

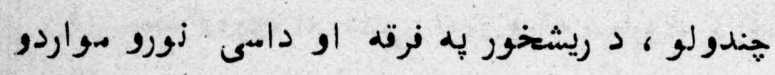

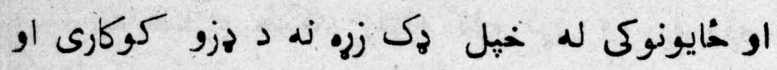

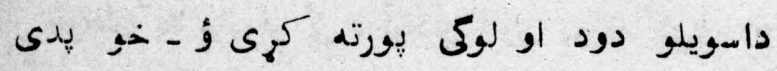

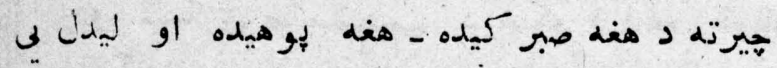

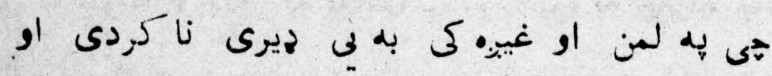

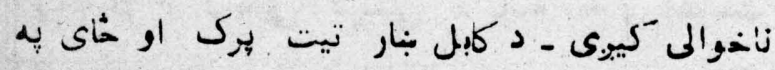

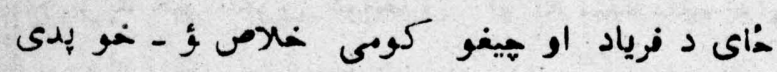

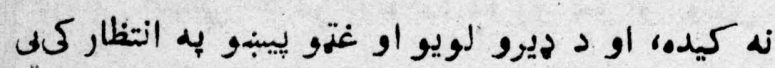
كرى شهارلى او لاره يى ورته نإكوله.

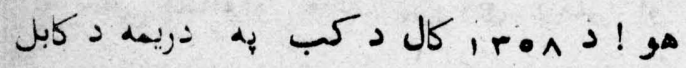

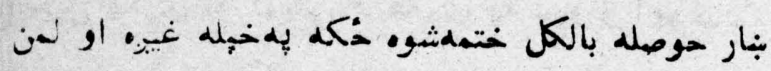

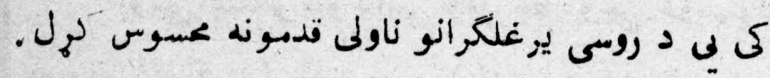

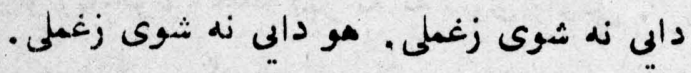

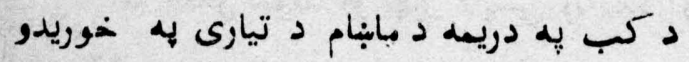

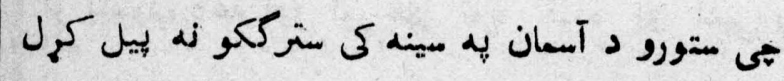

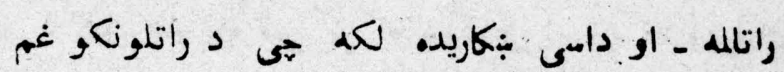

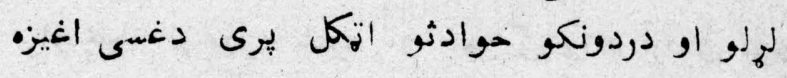

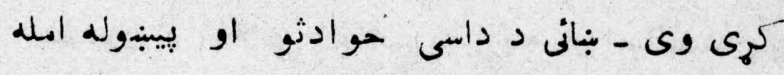

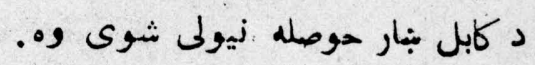

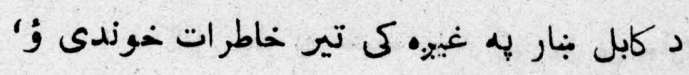

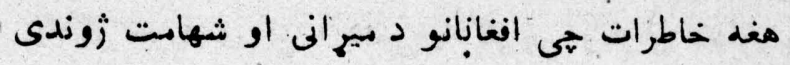

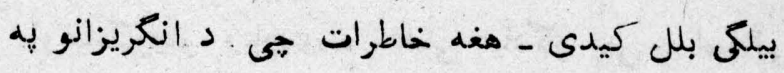

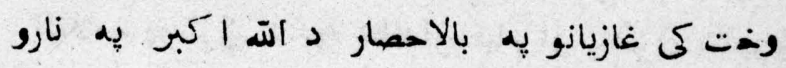

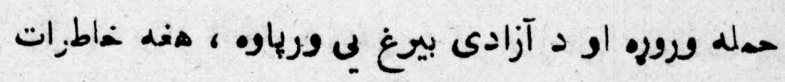

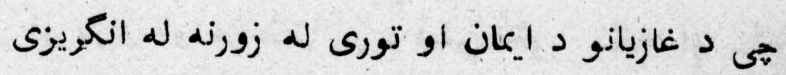

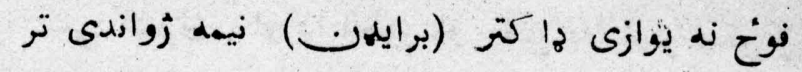

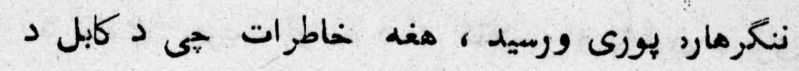

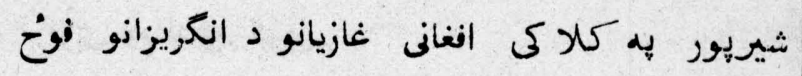

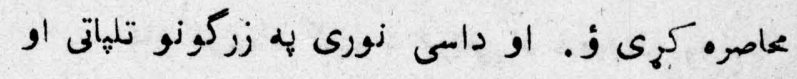
نه هيريدونكى خاطرى او كارنامى .

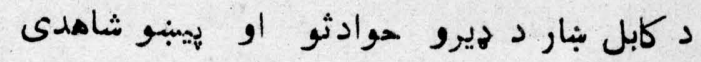

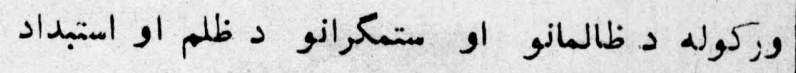

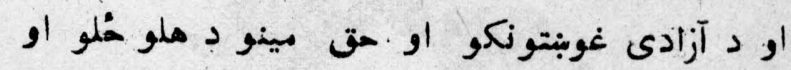

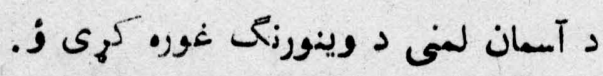

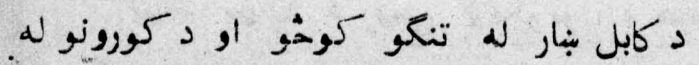

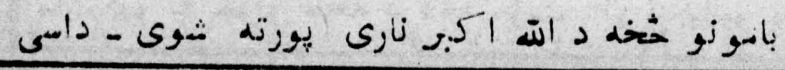


لور لمبى إيورته شوىيه ياخه سرك او واتو نوكىنوينو

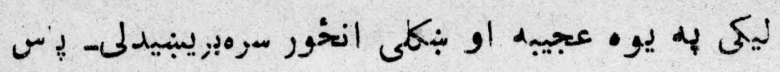

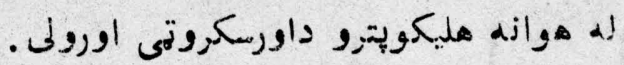

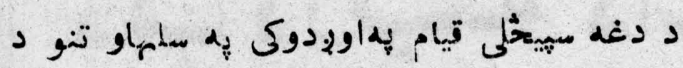

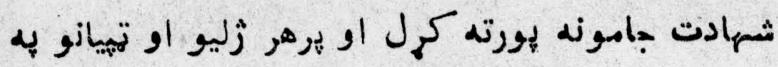

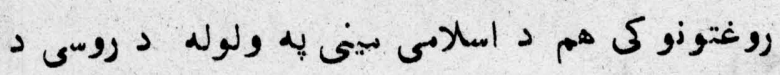

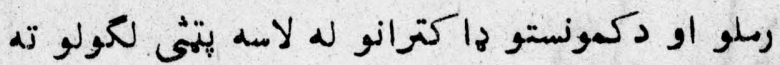

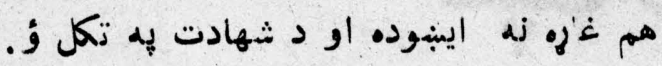
مغه ورخح د كابل بنار لكه تبى ايشيده او وينو

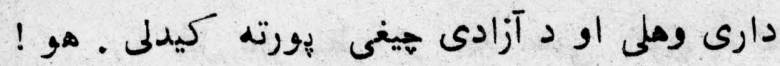

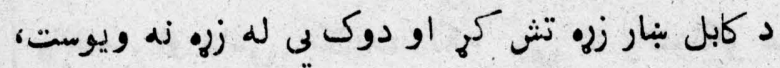

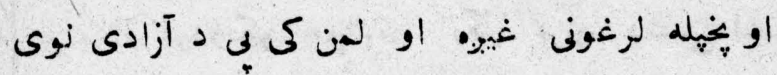

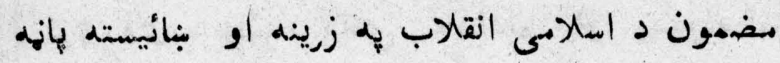
د وينو يه رنى انخور كم.

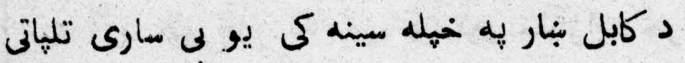

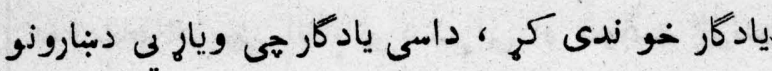

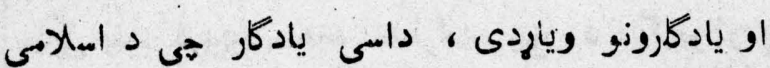

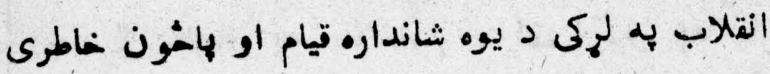

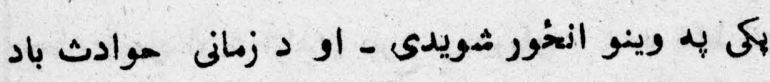

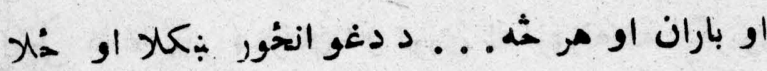

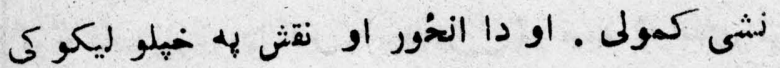

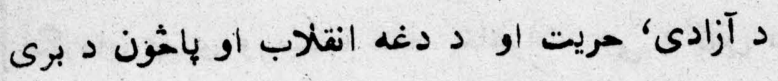
زيرى وراندى كوى.

باد دوى دكب د دريمى د شهيدانو روع !

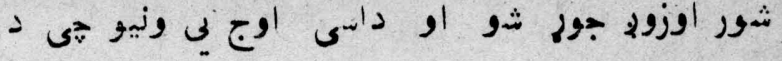

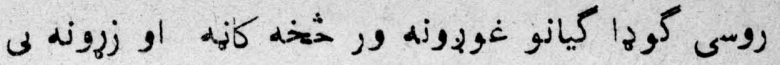

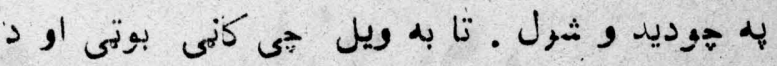

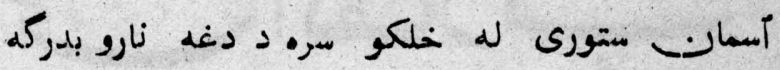
كوى . د اسلام دبنمنابِ وار خطا ؤ او زه يوهيدل

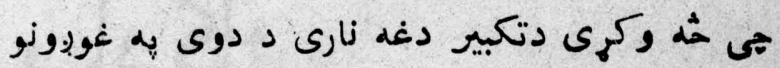

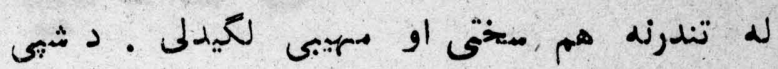

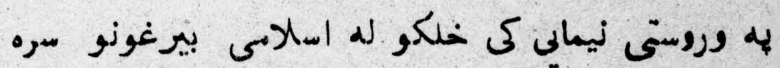

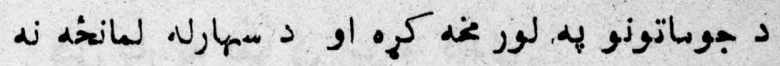
وروسته د اسلام بيرغونه هُ هله لاس د بنار او واتونو

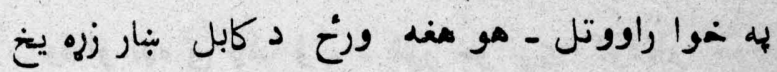
شو او ساه نى به آرامه ويستله.

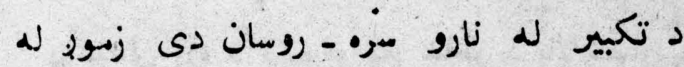
وطن خخخه ووزى او داسى نورو ورته شعارونو د كابل

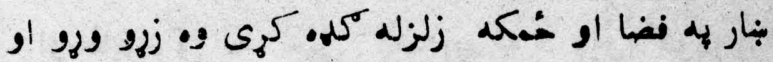

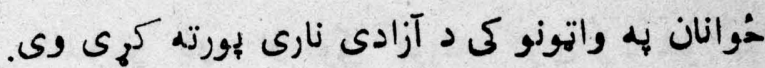

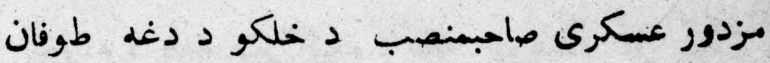

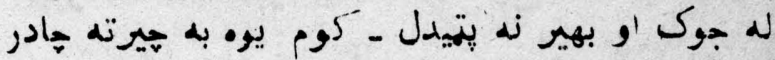

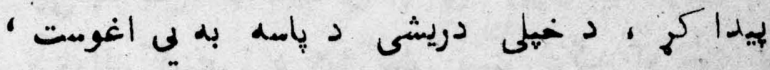

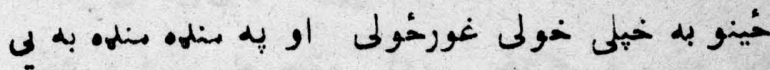

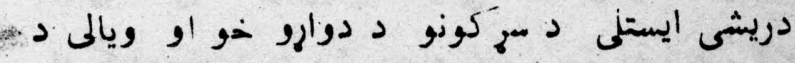

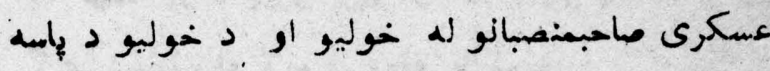

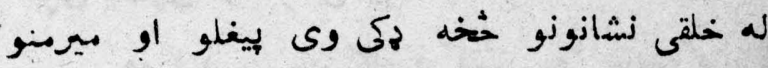

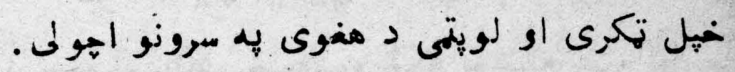
روسى عسكر خو داسى وار خطا ؤْيى. دومنينوله

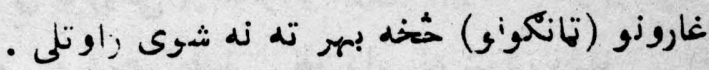

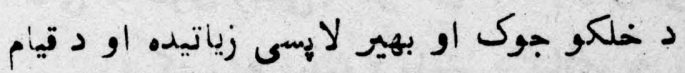

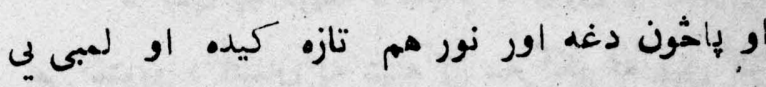

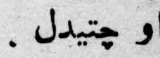

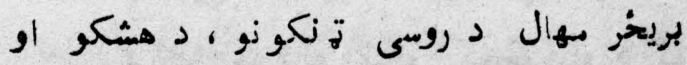

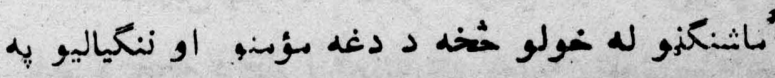


نويسنده : دكتر عبدالحى "لنجشيرى"

ㅁㅁㅁㄷ

ㅁㅁㅁㄷ

पㅁㅁㄷㄷ

ㅁㅁㅁㅁ

ㅁㅁㅁㅁ

믐ำ

ㅁㅁㅁㅁ

ㅁㅁㅁㅁ

ㅁㅁㅁㅁ

ㅁㅁㅁㅁ

ㅁㅁㅁㅁ

ㅁㅁㅁㅁ

ㅁㅁㅁㄷํ

ㅁㅁㅁㅁ

ㅁㅁㅁㅁ

ㅁㅁㅁㅁ

믐ㅁㅁ

$\square \square \square \square \square \square \square \square$

ㅁㅁㅁㅁ

ㅁㅁㅁㅁ

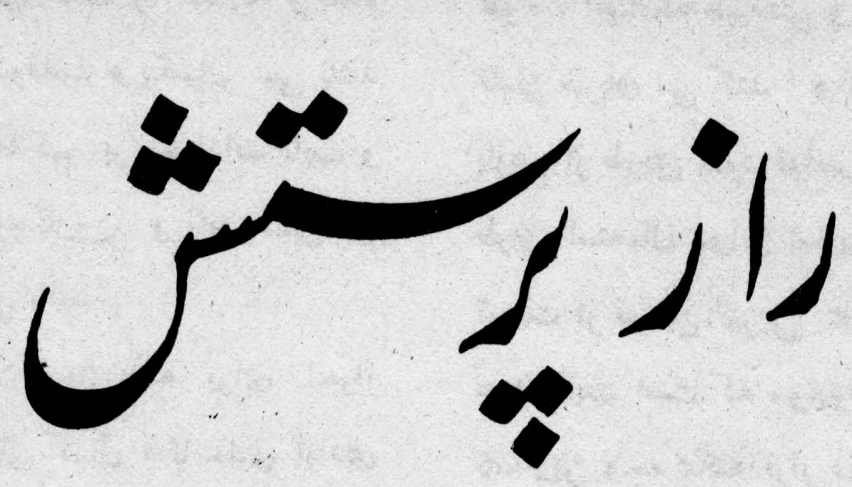

ㅁㅁㅁㅁ

뭄ㅁㅁำ

믐ㅁㅁㅁ

ㅁㅁㅁㅁำ

뭄ㅁㅁำ

믐ㅁㅁㄷㅁ

뭄ㅁㅁ

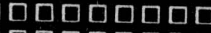

뭄ㅁㅁㅁ

ㅁㅁㅁㅁㅁำ

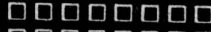

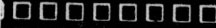

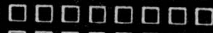

ㅁㅁㅁㅁㅁㅁ

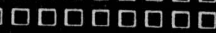

믐ㅁㅁㅁ

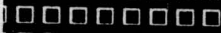

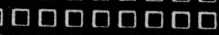

믐ㅁㅁㅁ

ㅁㅁㅁㅁㅁ

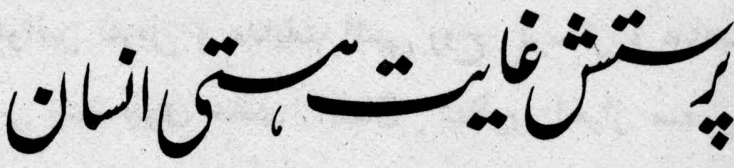

نباتات كتم نشان خود اراديت بروز مى دهند و به

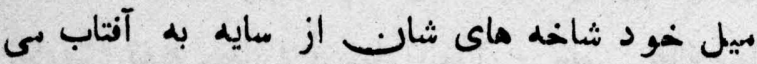
كرايند . ميوانات بيشتر ماحب كمال اند و از خود

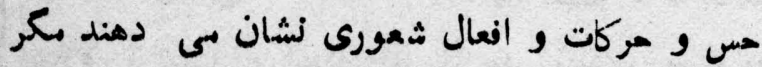
انكيزة سلوك و زمام انعال مثان بلستت غرائز و تمايالات طبيعى شان است . مكر انسان در قلة آفريده ها و مـتبل بر تريونـ مغلوقات از حيث فطرت خرد

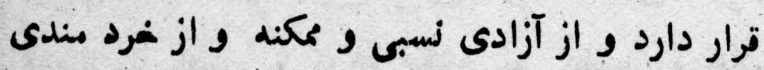

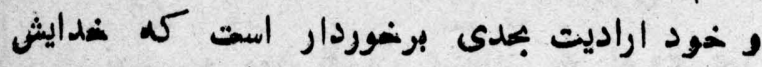
صورت سرشئ او را بهتين صورت ها (إحسن تقويم)

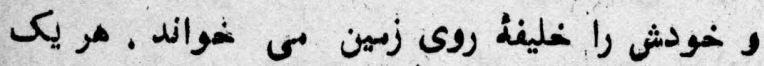

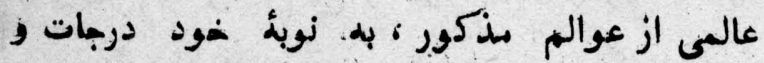

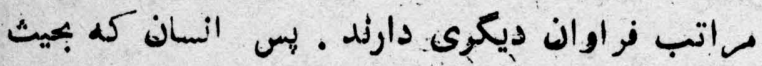
اكسل مغاوقات ـ مبلاتميت تكليف و مسل بار امانت را دارد ـ از آنـروست كسه تـا هـدى از انتينار بوخوردار و قدرت تصوف ه ابتكار و مدر بيهيى را داره و خون عنلوقات عوالم زبات و جماد و خيونان فاقل عقل و منطق و اختياراند ازينرو خداونت همك امور معثين ثانرا از طريق قوانين تكوينى و طبيغني

خداوند ـ_كائنات را بشهول انسان و ديكر مو جودات در كمهلترين وجه و در نهايت كمال مكنه

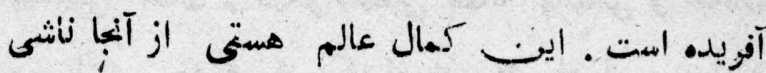
ميشود كل همه زرمانبر سنت هاى جاويدان و اوافـ تكوين آفريدكار شان مى بأثند . هيتع جزئى از اجزاء دستكاه آفرينش مجال كمترين تخلف از مششيت ازلف و

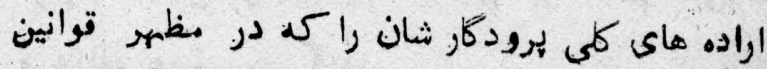
طهييعى ظهور مى كند، ندارد. مغلوقات درجه بدرجهو اجد كمل اند وعالم هستى داراى درجات وم اتبمتفاوتى از وجودكملال مي باثده. هر مـتبهازم اتبعوالمهستى نسبتبدرجهُ قبلى، متكمللتر ونسبت بدرجه بعدى، ناقصى ترست . هنانكه عالم جماد تخستين مـتبه را - عالم نبات درجه دوم را و عالم حيوان مهتبل سوم راو

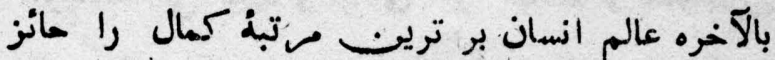

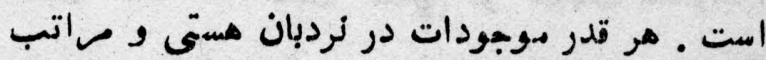

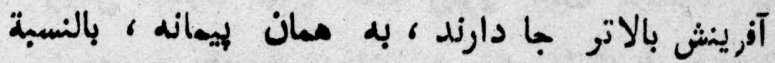
به مساتب يائينى تا مدى از خود اراديت و آزادى له له برخوردار مى باشند هنانكه جمادات كماتك مكوم قوانين تكوين بوده بلاختيار در حوكت مى باثند 
سائر موجودات عوالم هستى كريزى ندارد م رخواه

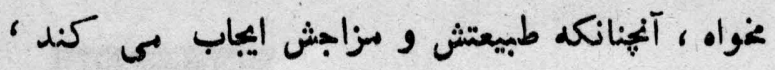

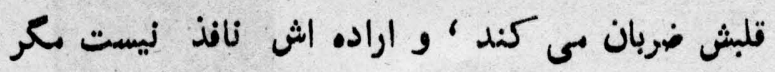

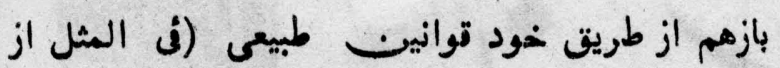

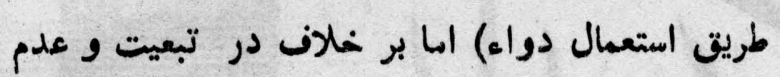

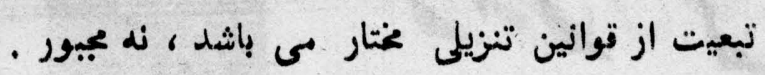

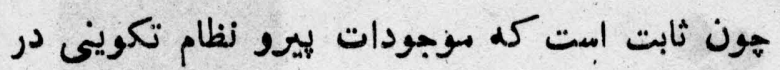

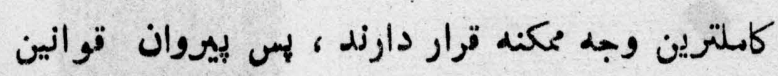

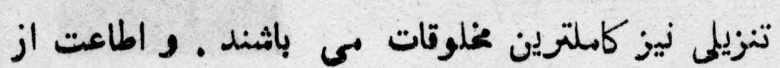

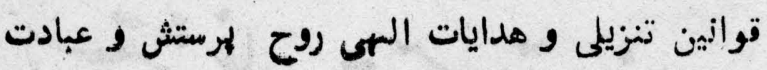

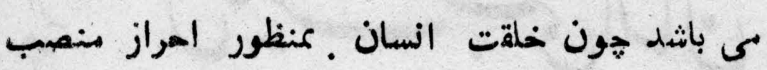

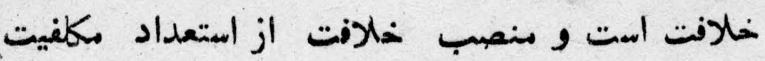

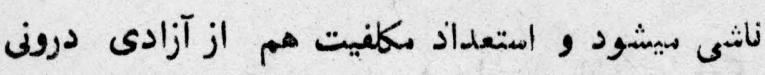

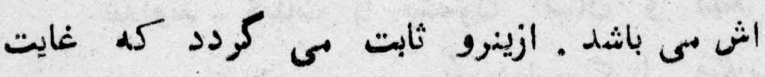

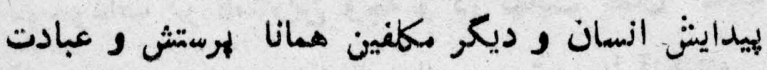

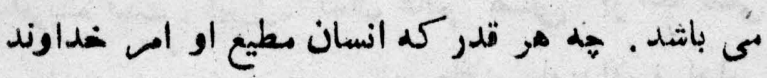

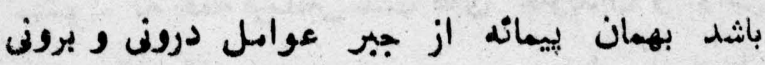

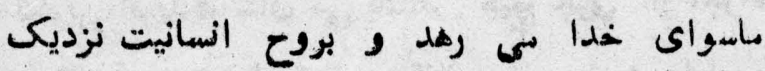

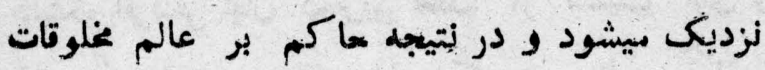
رعوالم هستى منى كردد

اين است كه مى كوئيم يشريت - وقتى بكمال

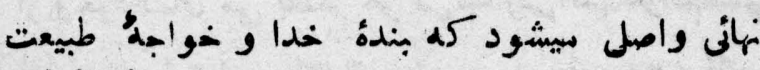

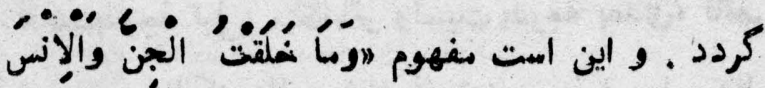

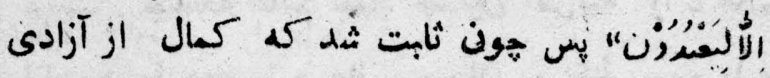

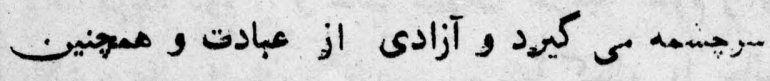

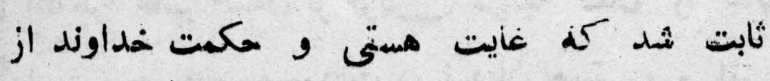

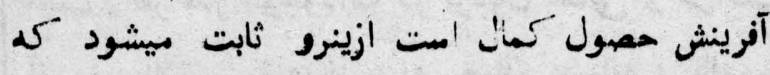

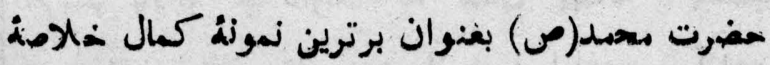
كائنات وزبدة: آفرينثي است .

$(2,104)$
و نهايتا از طريق نظام غرائز، تدبيه و سر رشته ذرده.

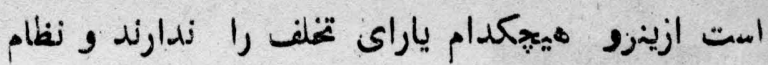

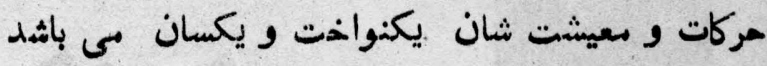

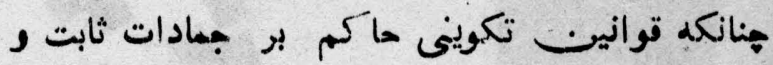

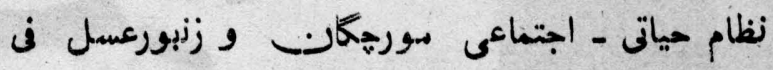

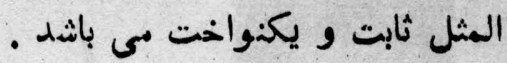
الما انسارـ هنــــ نيست باكه براى احراز

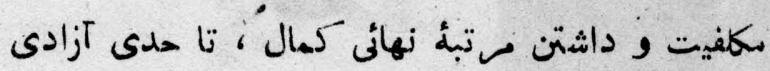

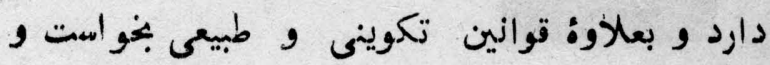

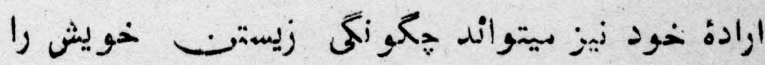

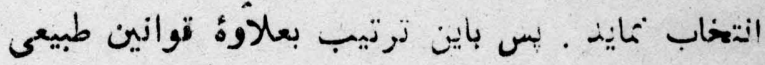

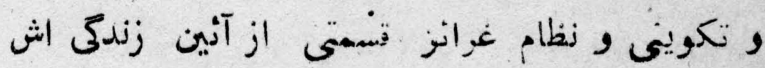

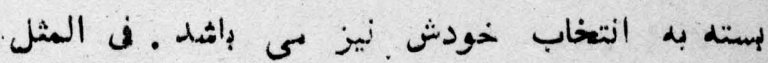

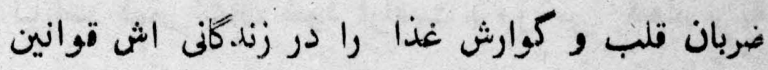

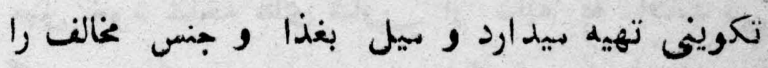

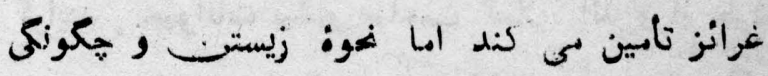

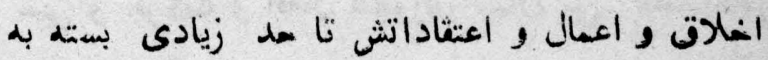
انتخابش مى باثد . ايستـ است كم انسان برخلاف

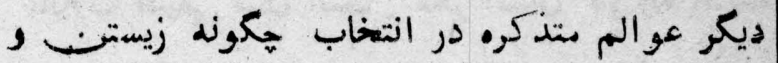

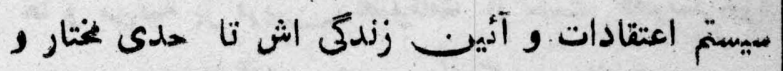

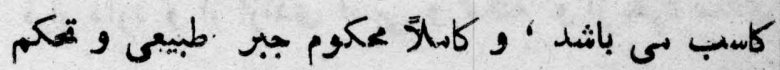

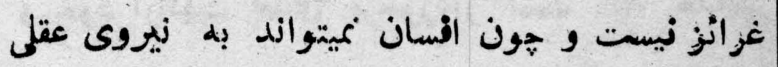

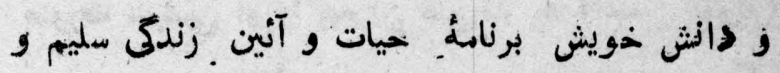

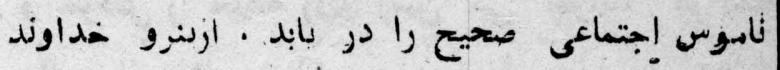

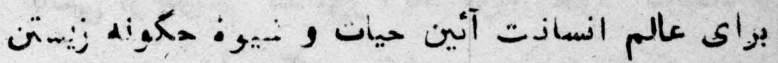
سليم را از صريو 'نبياء كرأم عليهه السلام عنايت

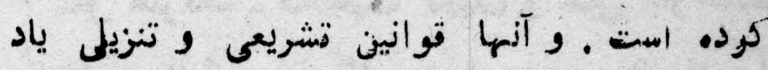

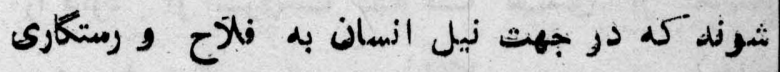

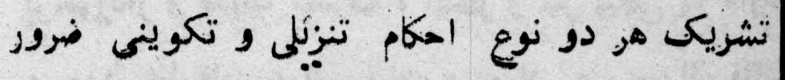

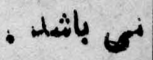
الما انسان ذر بيروى از قوانين طبيعى مانند 


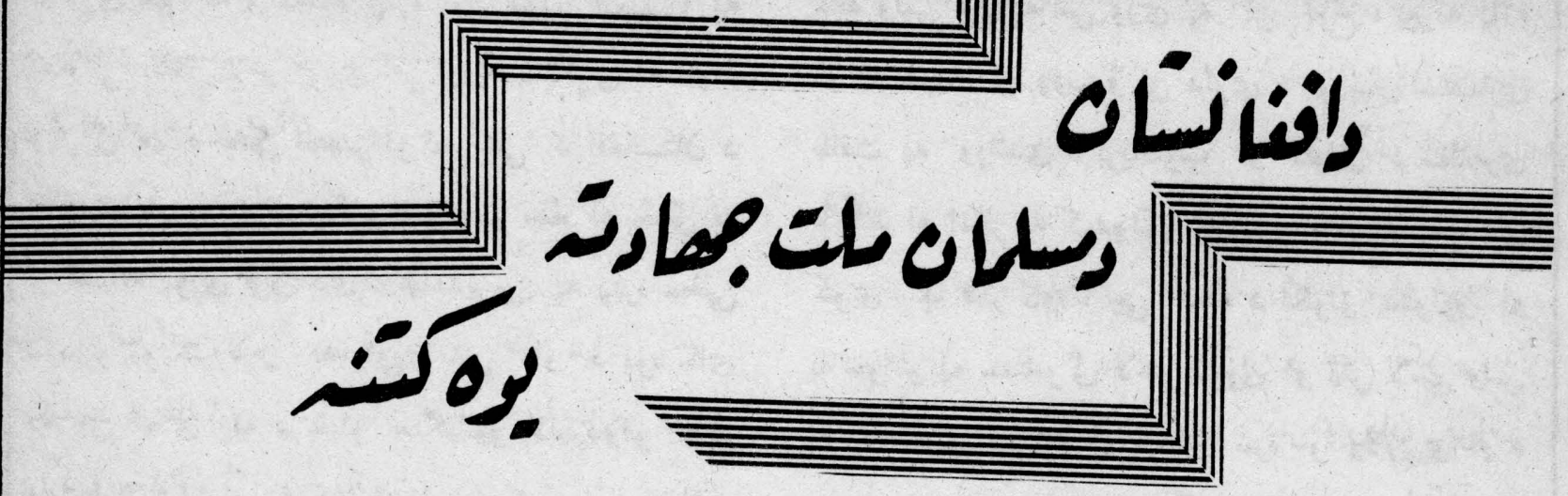

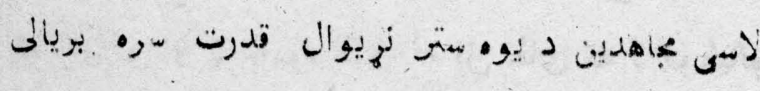

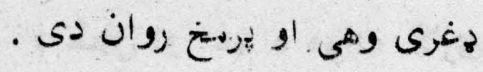

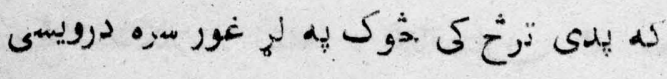

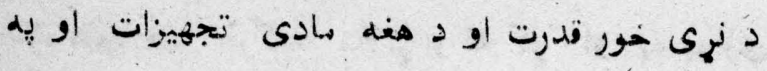

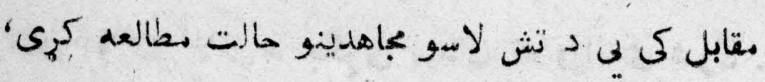

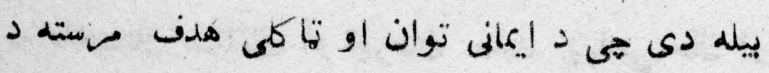

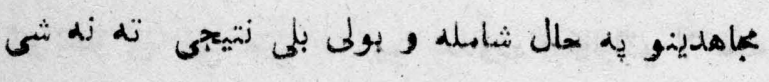
رسيدلى

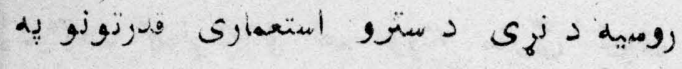

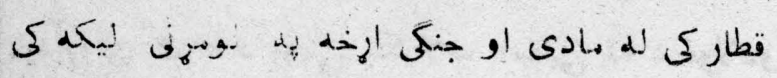

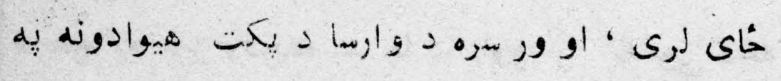

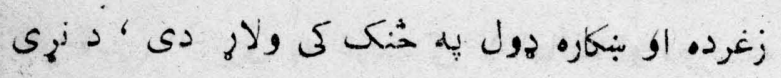

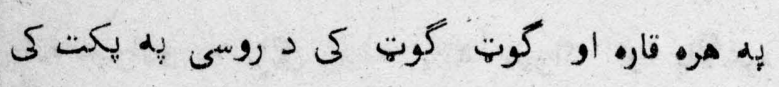

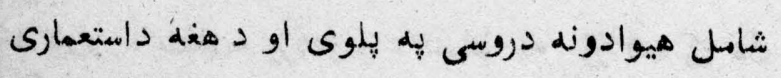

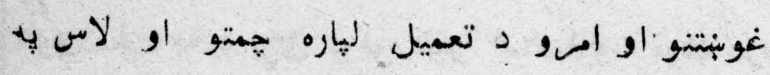

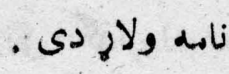

خو ددى بله مقابل كى د د افغانستان مسلمان

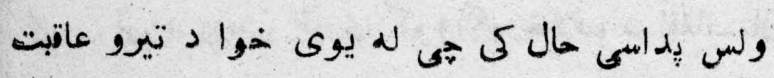

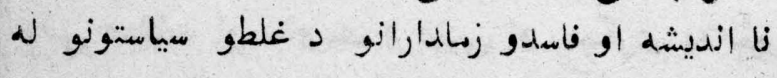

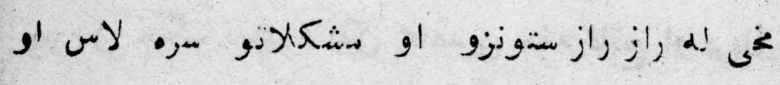

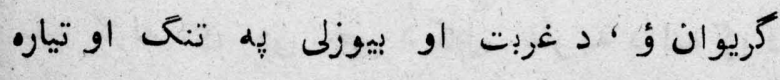

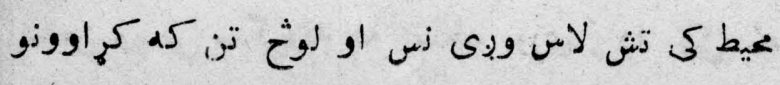
او زأحو الو سره مخامخ ؤ دحاكم الحادى نظام دد
به الفغانستان كى د روسى تيرى كوونكو خلاف

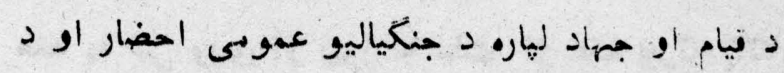

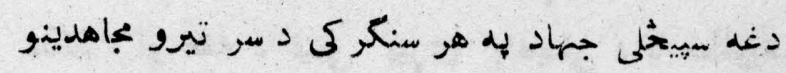

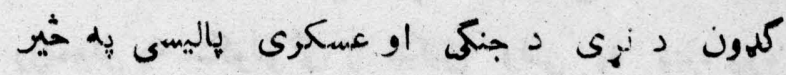

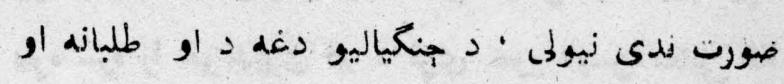

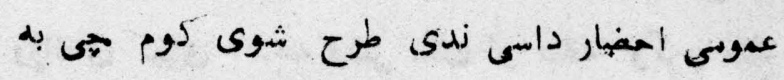

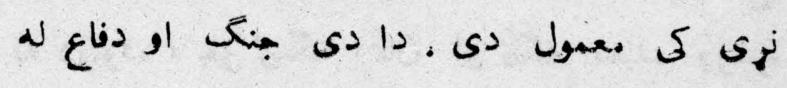

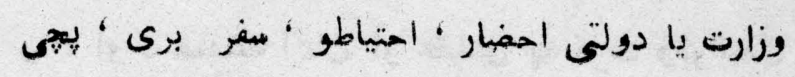

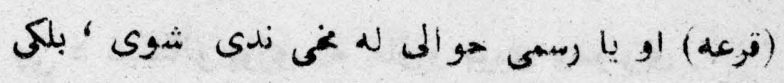

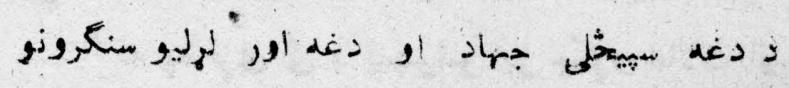

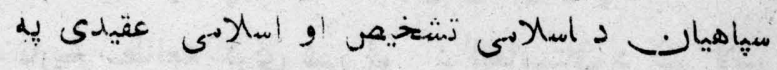

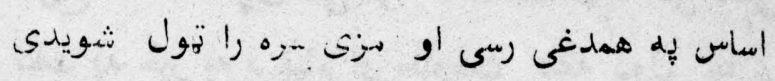

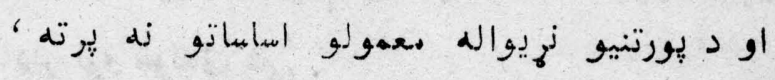

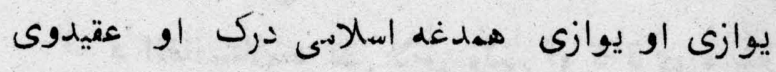

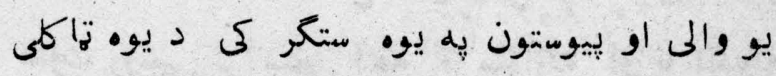

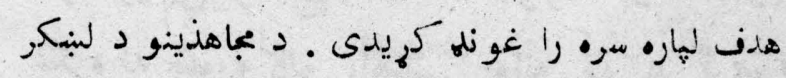

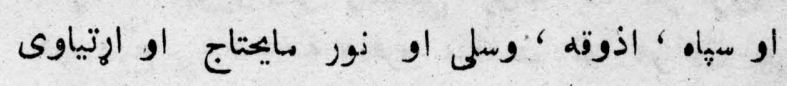

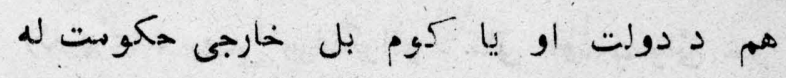

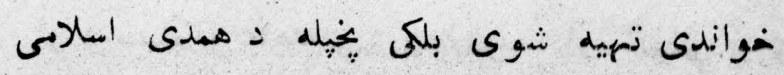

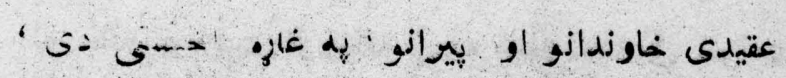

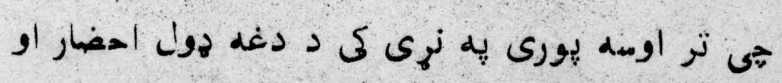

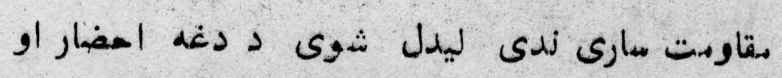
جياد همدا مشخصات او خصوصيات ؤ يى تش 
زور ذالستانو او خبريالانو هم برى اعنراف كرى دى

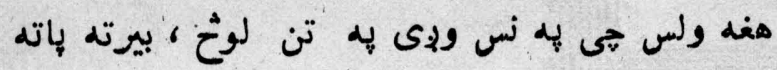

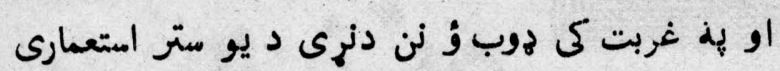

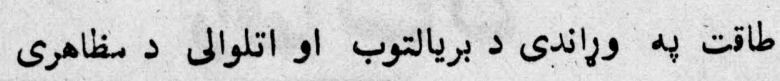

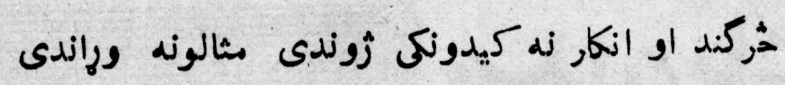

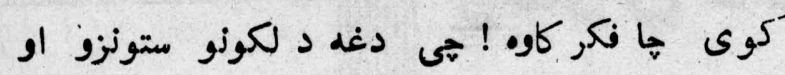

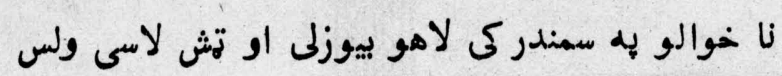

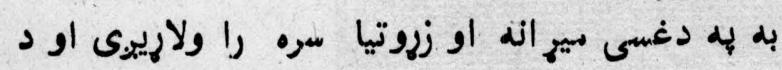
روسيى غوذندى طاقت به به كونلهو كوى .

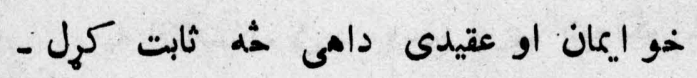

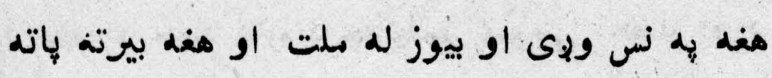

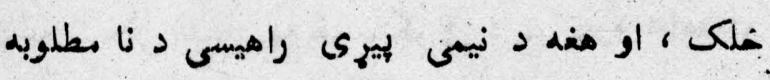

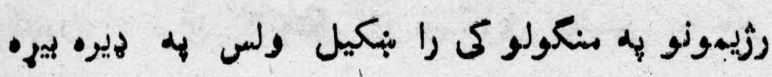

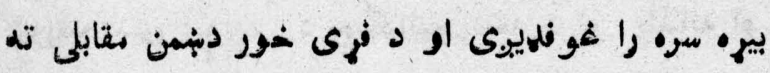

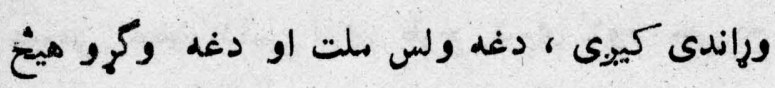

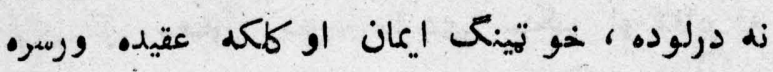
وه ، او. د همدغه ايمان او عقيدى لهيه قوت وتوانيدل

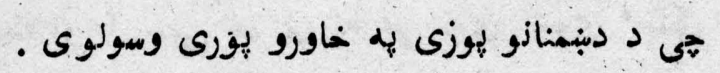

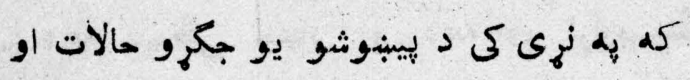

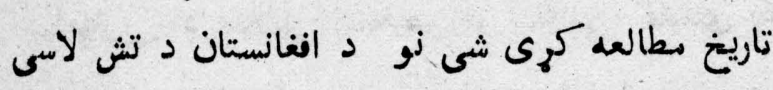

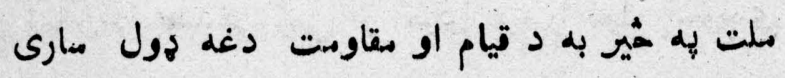

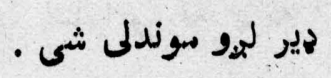

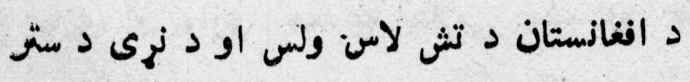

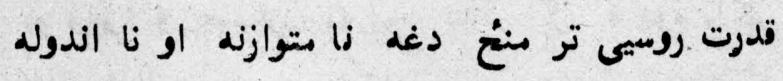

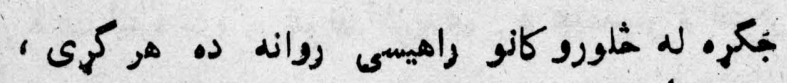

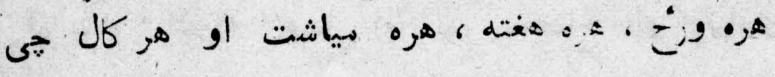

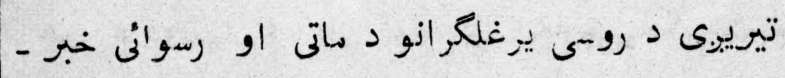

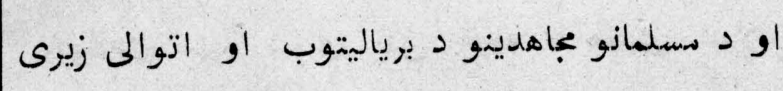

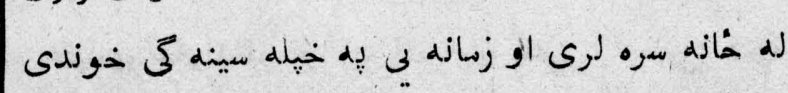

(jور يبا)

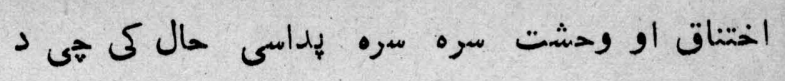

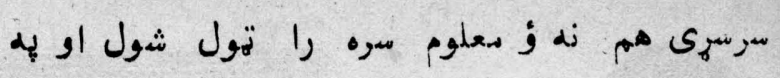

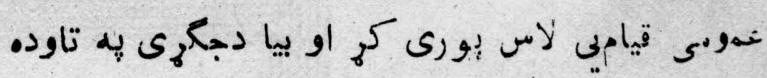

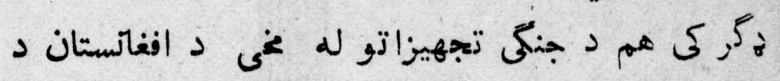

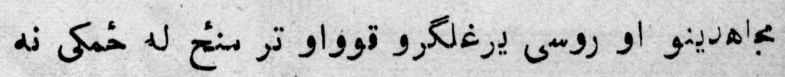

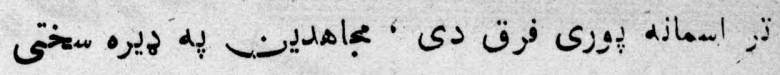

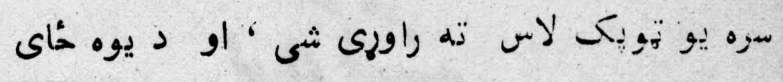

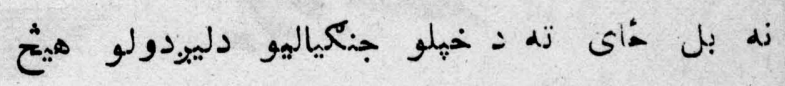

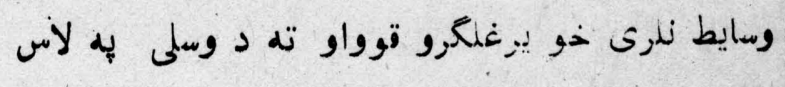

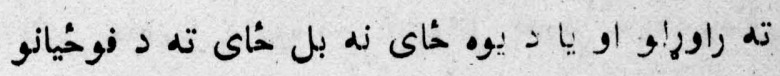

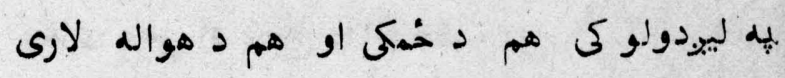

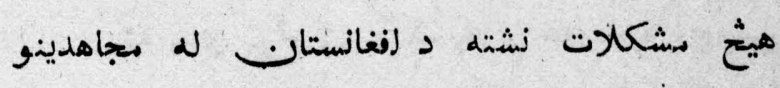

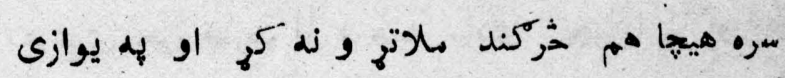

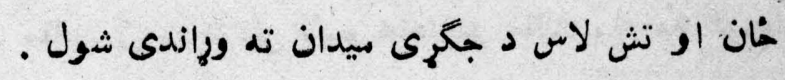

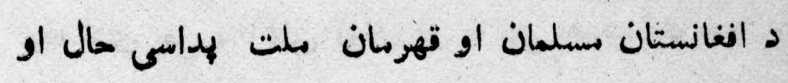

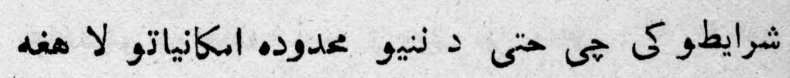

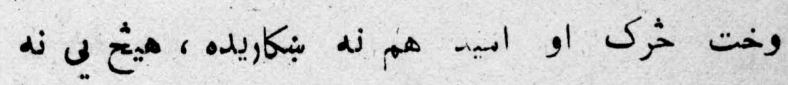

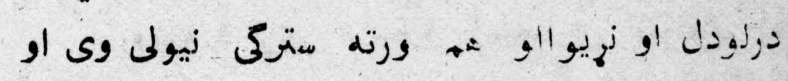

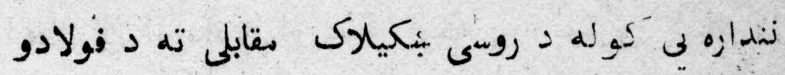

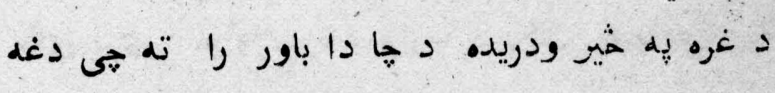

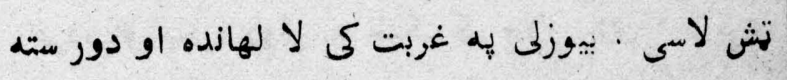

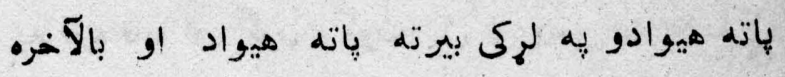

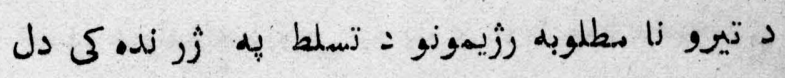

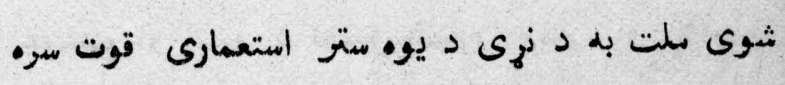

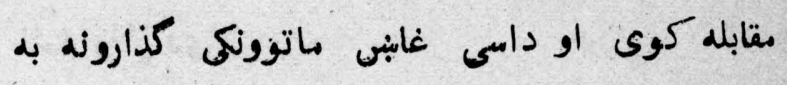
نن د روسى تيرى كو ونكو خلاف د افغانستان

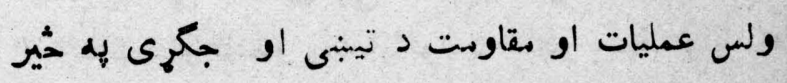

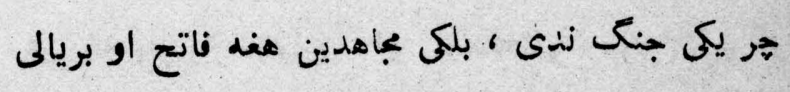

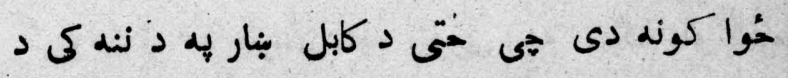

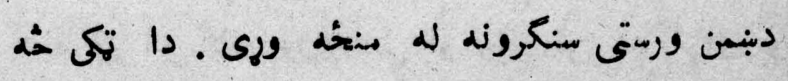
مبالغه نده بالكى يو ريبنتى واقعيت دى ثي د زيى 
$V_{9}$

بينسواثي تو ، زوالباتهو بـود

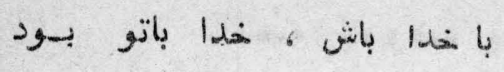

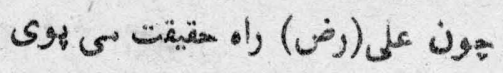

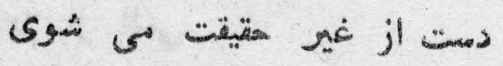

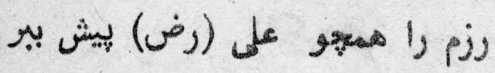

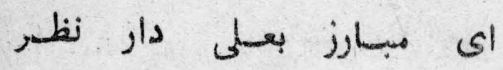

N 5

آى مجاهـد بيهـادى و رجهاد

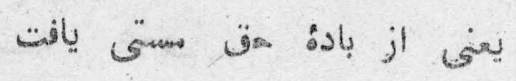

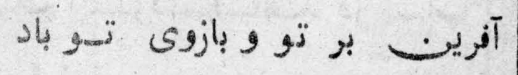

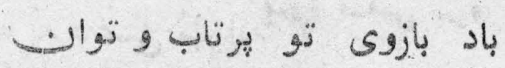

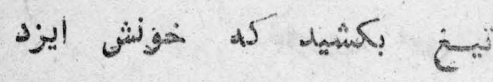

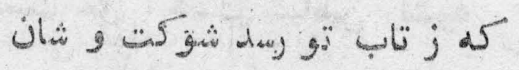

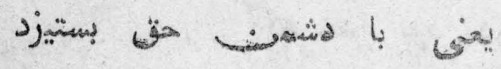

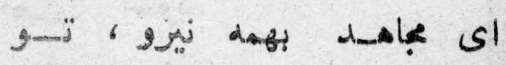

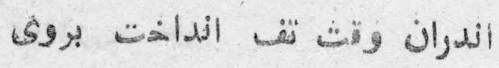

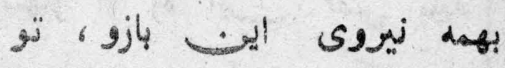

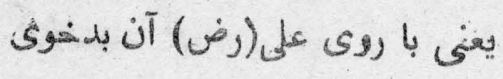

تانس

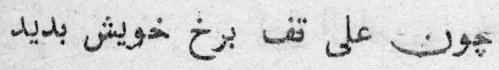

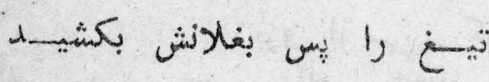

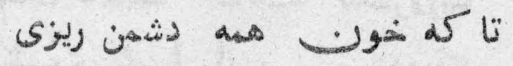

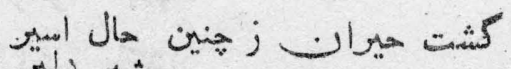

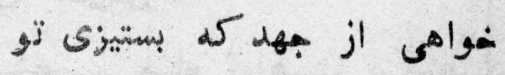

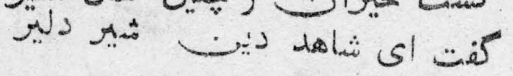

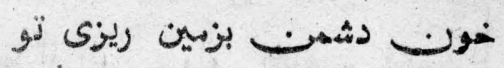

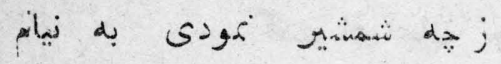

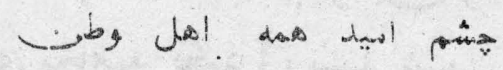

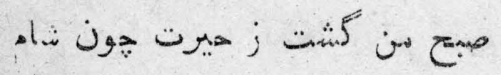

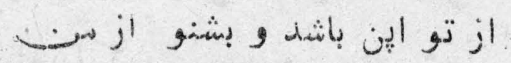

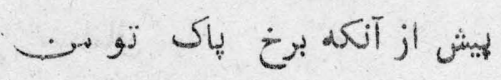

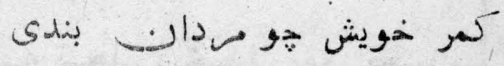

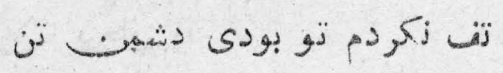

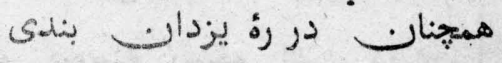

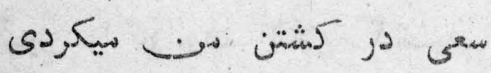

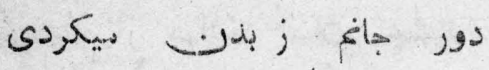

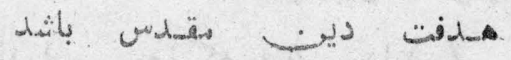
هيف ديرن ترا بس باثشد

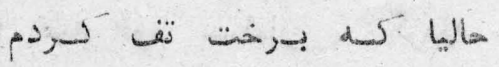

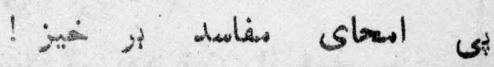

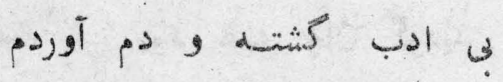

سعد(رض) كرديده وضمالد(رض)بوضييز

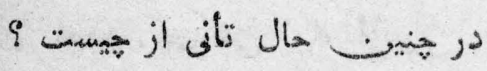

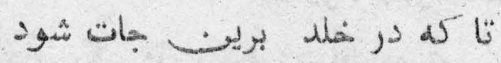

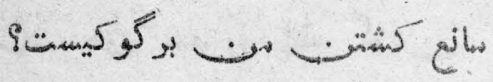

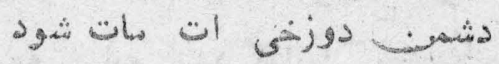

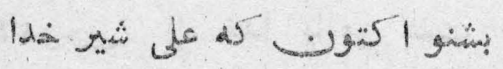

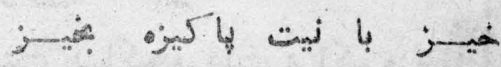

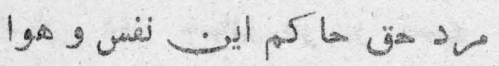

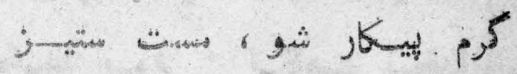

بجوابش

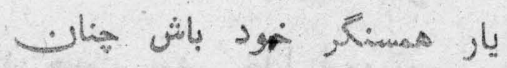

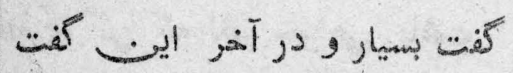

نال

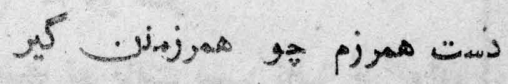

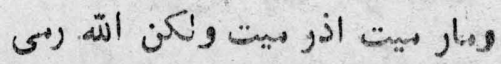

ستخ 


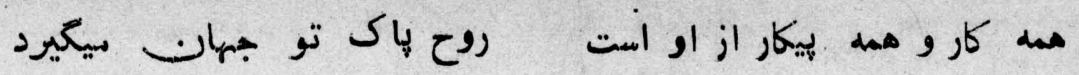

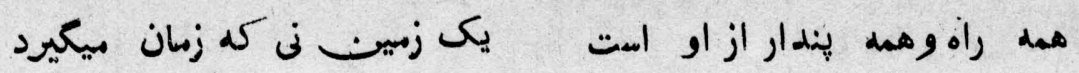

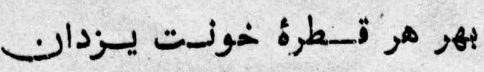

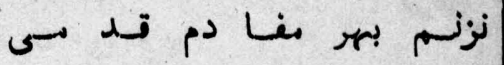

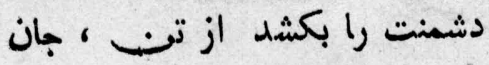

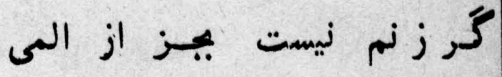

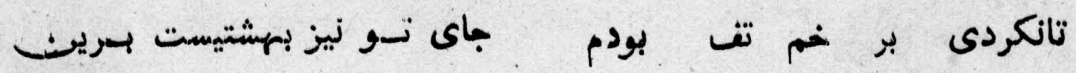

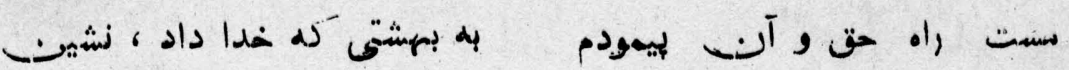

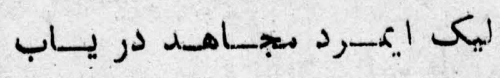

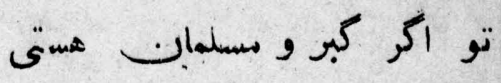

برة نسف هو ، نيست مسواب

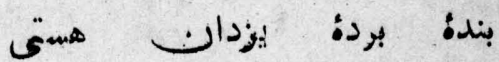

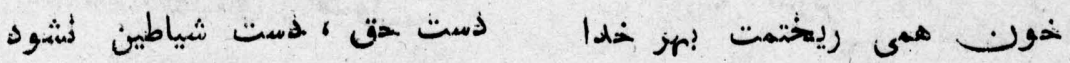

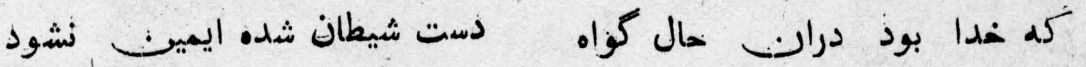

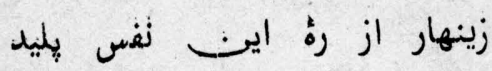

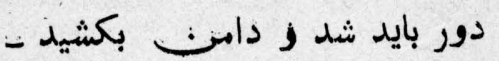

$$
\begin{aligned}
& \text { نقس يجيهد ز تف كردلب تو تو }
\end{aligned}
$$

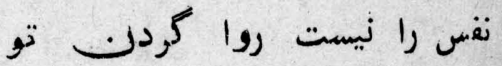

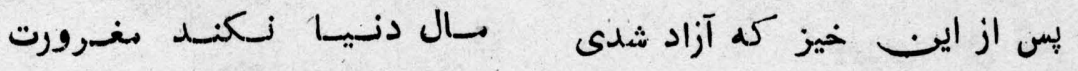

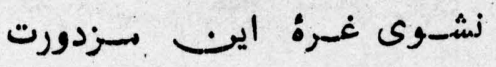

مسنصب جـاه زراهـت نكشند

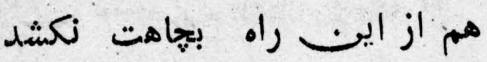

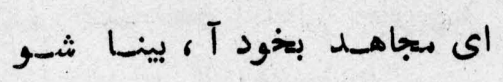

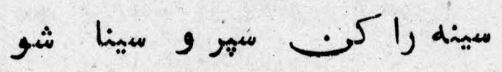

هـ تهجلى ز خهدا روز نخست

بتو بيوسته رسيده است درست

اندراب روز كه با نام خدا (ج)

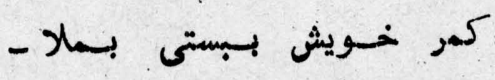

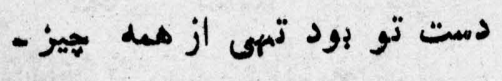

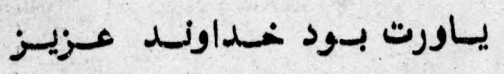

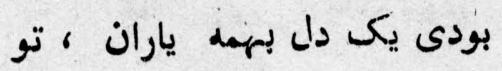

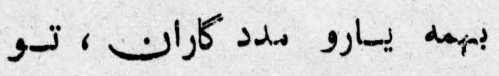

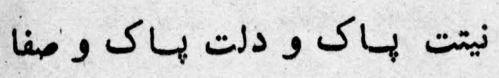

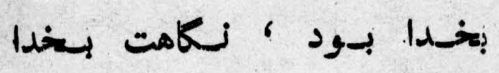

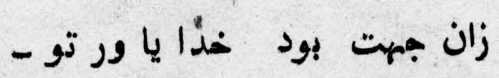

اد ورى كرد بسى دا ور تسو

دست تو يافت بسى تاب و توان

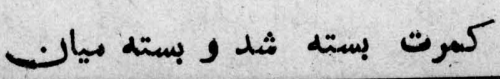

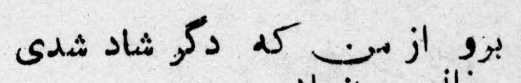

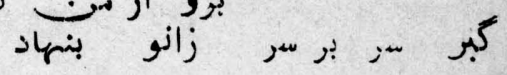

بخضوع و بخشوع لب بكشاد

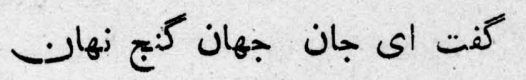

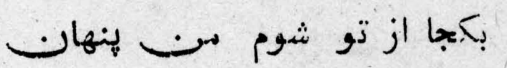

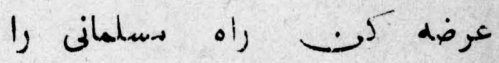

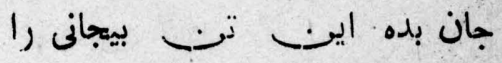

ك-ب را دول-ت اسلام كشـيد

شربست از بـادة اسلام هشيد

با

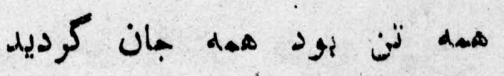

اى

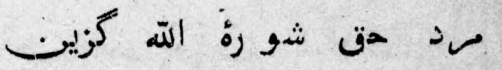

كازدريــــ راه خدا يا ور تسهت

كامياقى دو جهان در بر تستي

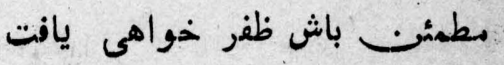

نظرى كن كه لظر خواهى يالهت

يا باينـ نيت اكر كشته شوى بامث

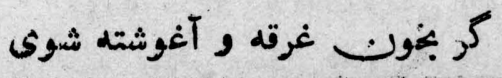


يكى كروميكهـ كـروه كرا انـــ

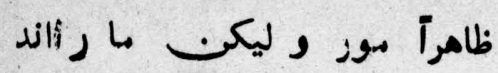

شعله هـا نيز بزيز هيرده

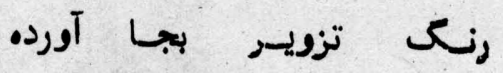

باهمه اين توز خهود خواهى خويش لئ

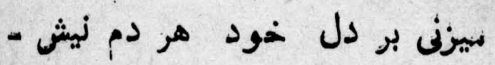

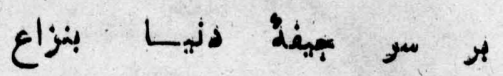

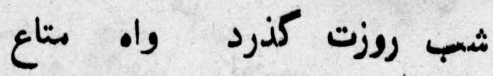

ايسنـ بتاع دام ثكست تو بود

بكذر ايســ كم بدست تو بود بود بود

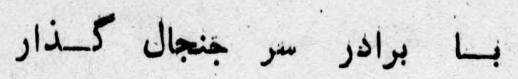
يار شو با همه و, برالـال كذار

دي-و هـائيكه زهادند زهاد

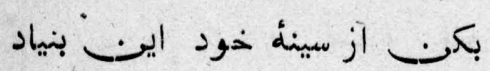

راه ده بر دل خود عقل و ملكى

تا كه ايسلـ هر دو رساند بفلكى دول

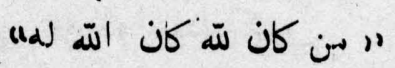

با خدا باش خدا را درياب

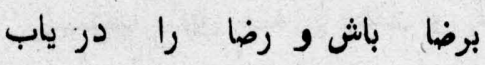

تا از ايــــ راه بمقصود درسى

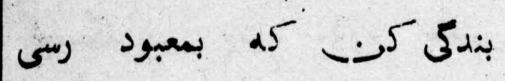

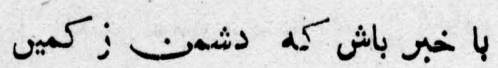

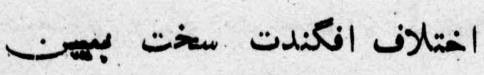

دست او كار كند سر و عله

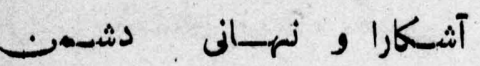

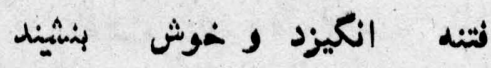

خـار انـدازد و كلها

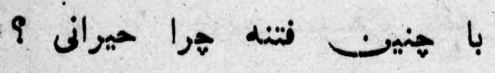

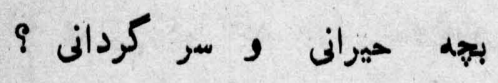

هشيم بكشاو بعبرت بنكـر

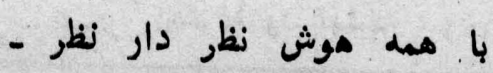

ابتلا بـود غـدا را بـا تهو

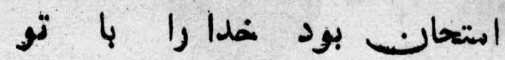

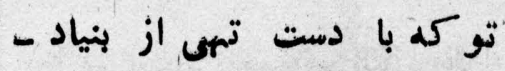

-

مال كم تاب و توانت باثد

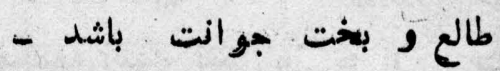

از جه تغيير نمودى الكنولنه

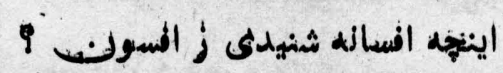

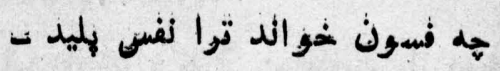

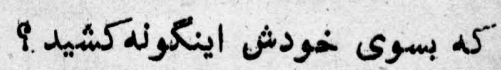

جه فسون خواند ترا حرض و آز

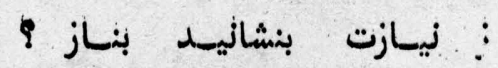

$$
\begin{aligned}
& \text { جهُ فيسون خو اند ترا منصب جاه } \\
& \text { اهل } \\
& \text { MYY }
\end{aligned}
$$

روسى از خال تو بيروسنـ رنته

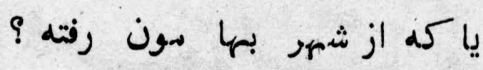

قدرت يرجميالن كشته تباه

خلقيان جماله فتادند

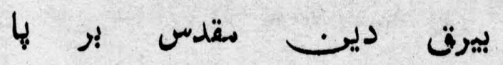

كشثته در شهر و نواحى بالا

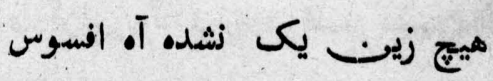

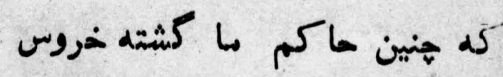

روس را سمتت قرإر است مدار

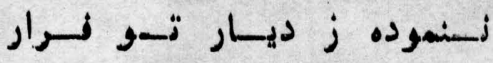

تانكى , طيسار. , تجهيز اتش

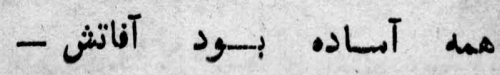

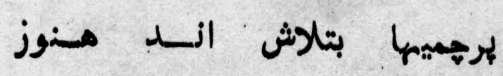

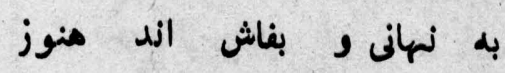

خلقيالن نيز صداما مارند

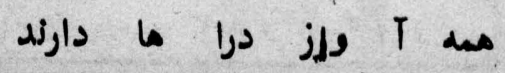




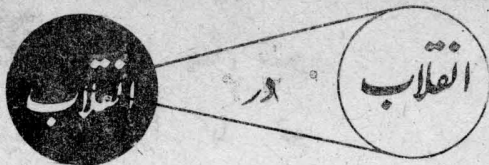

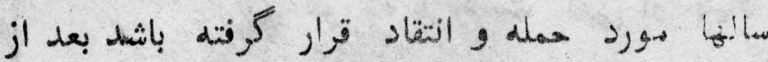

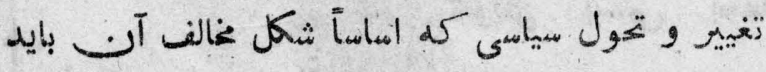

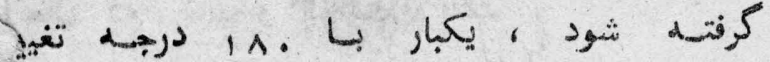

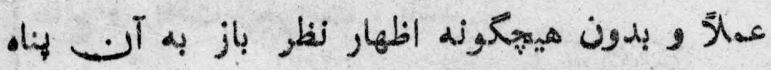

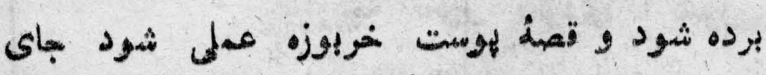

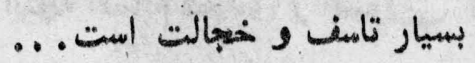

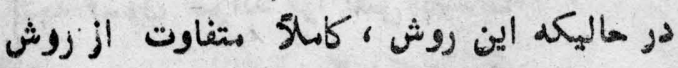
آن طبقات اسمت زيزا طبقات ها كملة آن زمان ، زندكى يز مصوف و لوكس را از بدران خويش به ارث برده بودند و كمتر كسئى يافت هيشيد كله با بقدرت رميدل
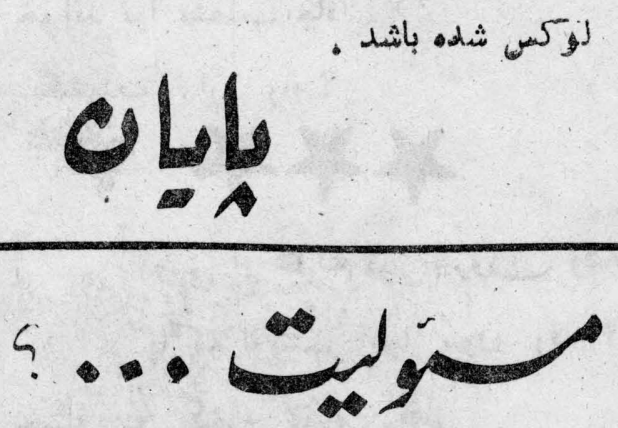

بيم و خوفن و بلون آنكله رعايت غاطر اربا بان و قلدر تممندافن را نموده باثيد وبه آنكه تعصبات ك كرايش

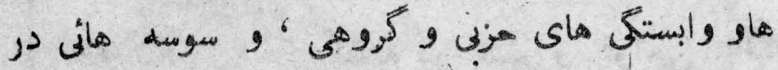

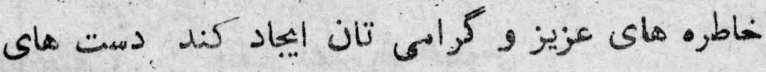
آغشتهل يخون و آلوده بكناه اين و آن را سعخت بربندبد

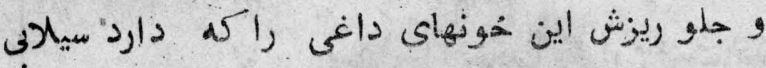

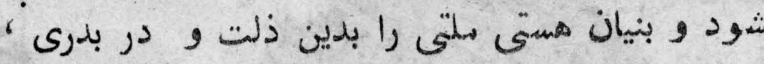

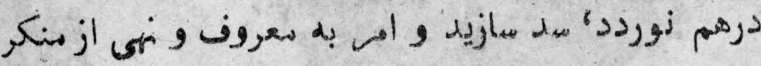

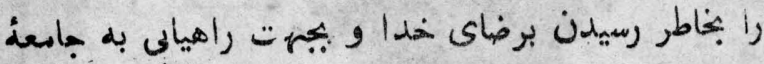

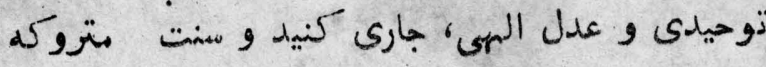

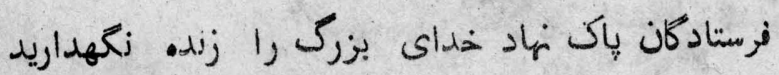
 عظيم و عصر هاى ى

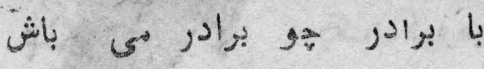

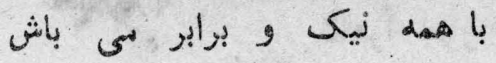

$$
\begin{aligned}
& \text { كاى } \\
& \text { خوب ايثار : فدا كراى كر كـــ }
\end{aligned}
$$

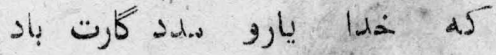

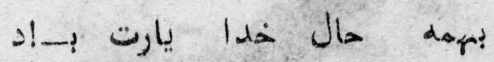

\section{(تl-ino)}

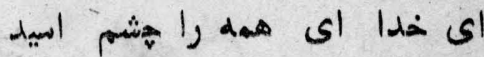

باميد تو جهاربنـ راست . زويد

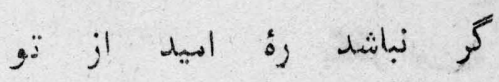

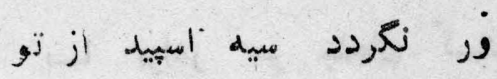

ز زئد

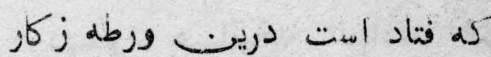

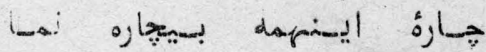

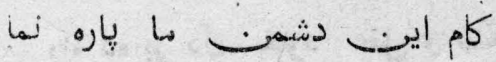

زشتى

تو

L. تو

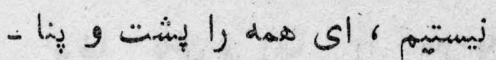

$$
\begin{aligned}
& \text { بر در تو سمر خود را بزميهـ }
\end{aligned}
$$

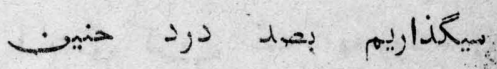

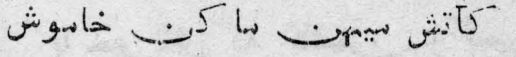

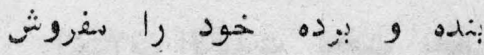

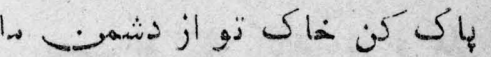

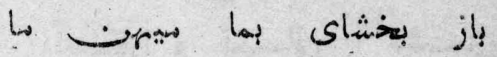

نايس

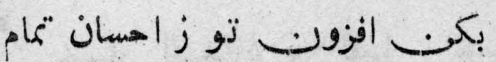

باز از دولت انسلام وسالن دولتى كو كم بود باويدارن

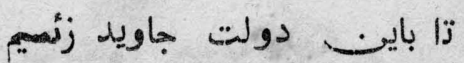

دولتي استت كله جاويد زئهيم 


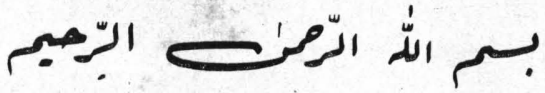

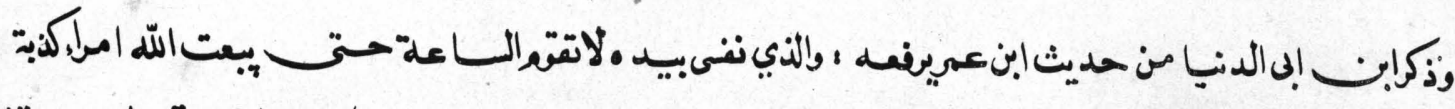

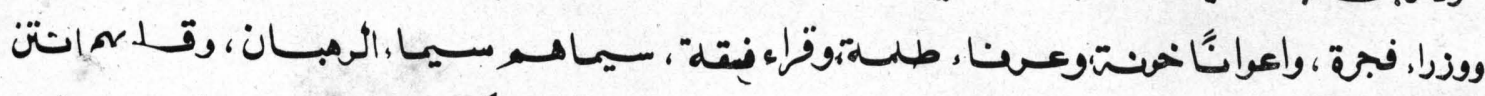

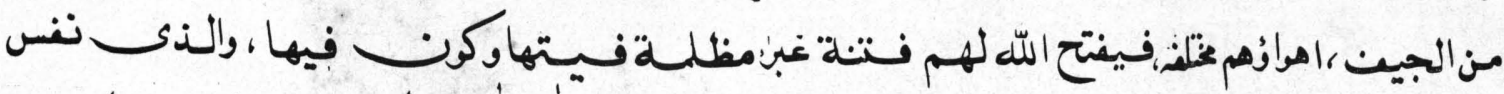

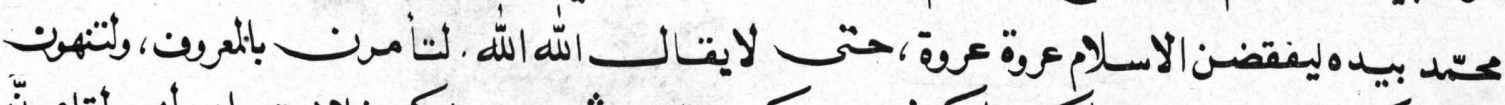

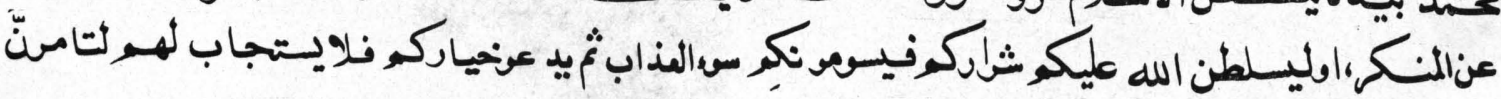

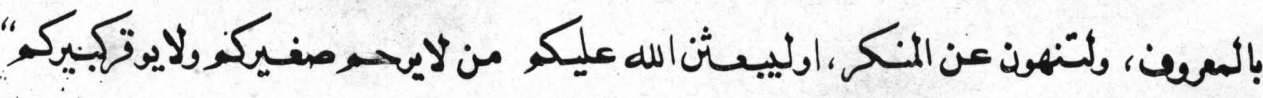
جأب الكانيصنسي

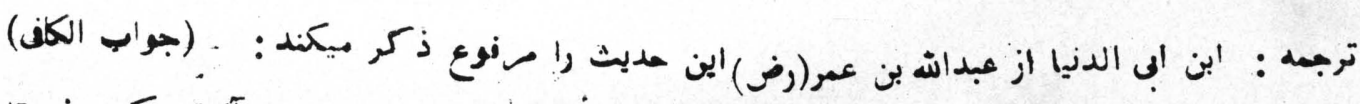

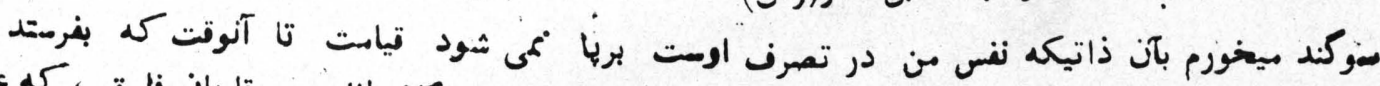

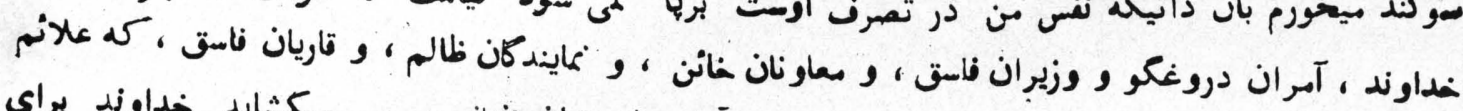

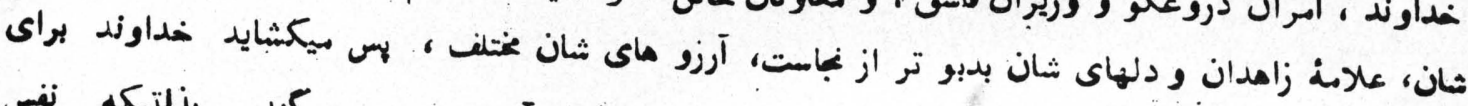

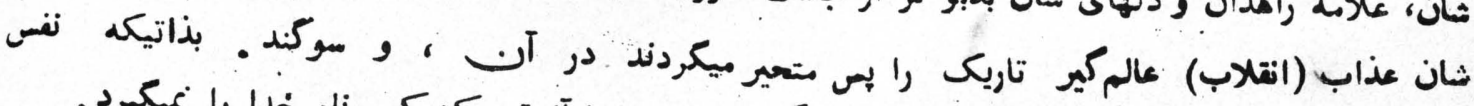

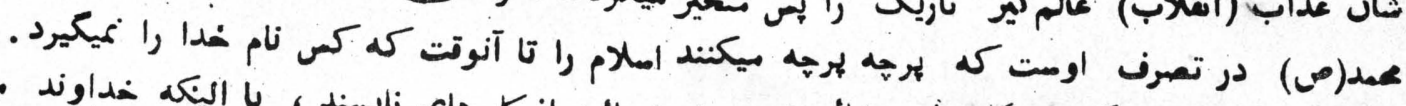

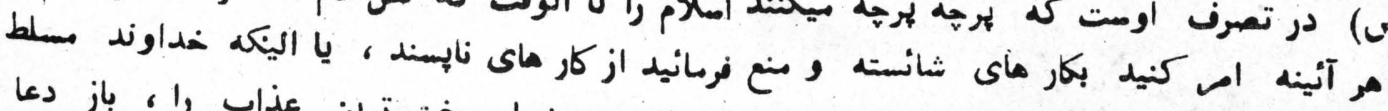

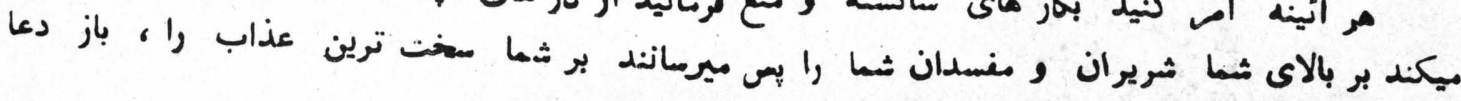

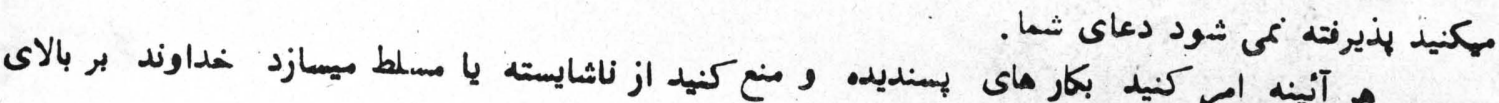

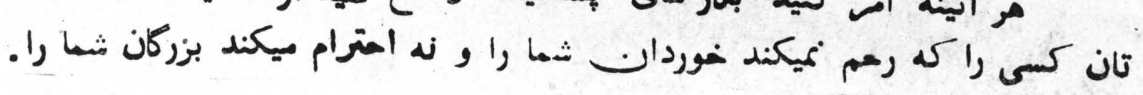

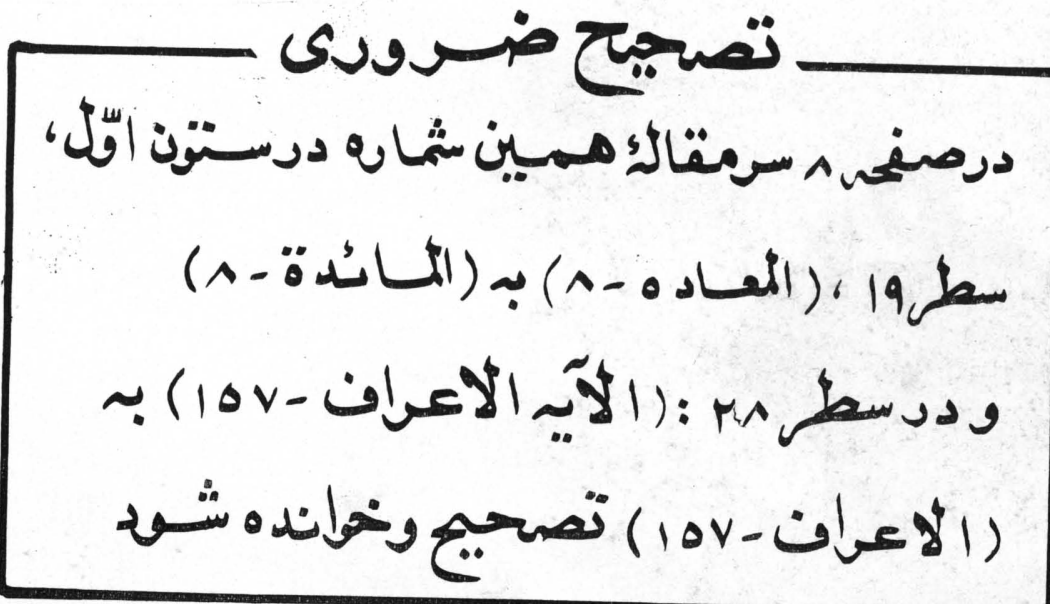




$$
\begin{aligned}
& \text { آنانك نياربمنين }
\end{aligned}
$$

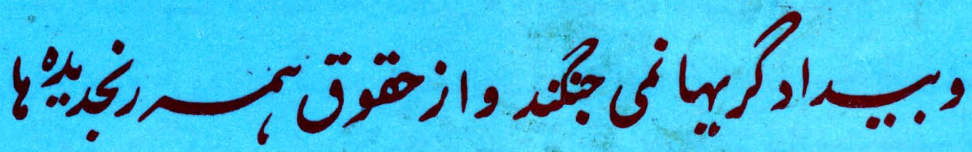

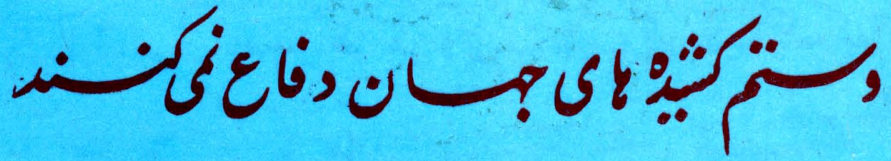

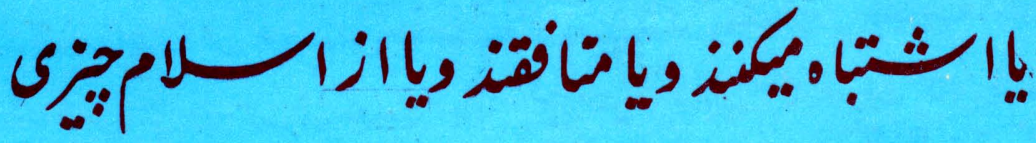

$$
\begin{aligned}
& \text { ن نهيُْاند } \\
& \text { (سيّبد قطب تنهيد م) }
\end{aligned}
$$

\section{قمتتكثنمار:}

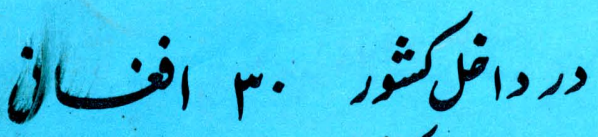

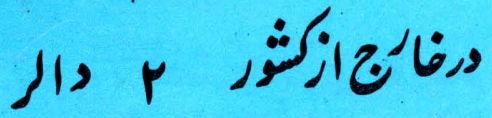

